\title{
AGENDAS DE INVESTIGACIÓN EN BIBLIOTECOLOGÍA E INFORMACIÓN: tendencias nacionales e internacionales
}

\author{
Jaime Ríos Ortega \\ César Augusto Ramírez Velázquez \\ (COORDINADORES)
}




\section{La presente obra está bajo una licencia de:}

\section{http://creativecommons.org/licenses/by-nc-sa/3.0/deed.es MX}

\section{Atribución-No Comercial-Licenciamiento Reciproco 3.0 Unported}

Eres libre de:

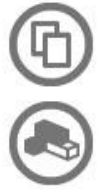

copiar, distribuir y comunicar públicamente la obra

hacer obras derivadas

Bajo las condiciones siguientes:

Atribución - Debes reconocer la autoría de la obra en los términos

especificados por el propio autor o licenciante.

No comercial - No puedes utilizar esta obra para fines comerciales.

Licenciamiento Recíproco - Si alteras, transformas o creas una obra a

partir de esta obra, solo podrás distribuir la obra resultante bajo una licencia

igual a ésta.

\section{Esto es un resumen fácilmente legible del: texto legal (de la licencia completa)}

En los casos que sea usada la presente obra, deben respetarse los términos especificados en esta licencia.
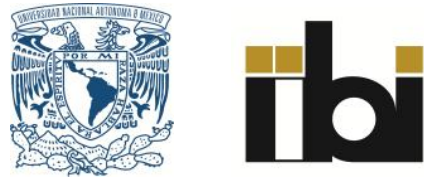
Agendas de Investigación en Bibliotecología e Información: Tendencias nacionales e internacionales 
COLECCIÓN

SiSTEMAS BIBLIOTECARIOS DE INFORMACIÓN Y SOCIEDAD

Instituto de Investigaciones Bibliotecológicas y de la Información 


\title{
Agendas de Investigación en Bibliotecología e Información: Tendencias nacionales e internacionales
}

\author{
Coordinadores \\ Jaime Ríos Ortega \\ César Augusto Ramírez Velázquez
}

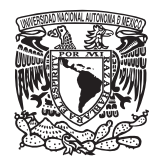

Universidad Nacional Autónoma de México 2013 


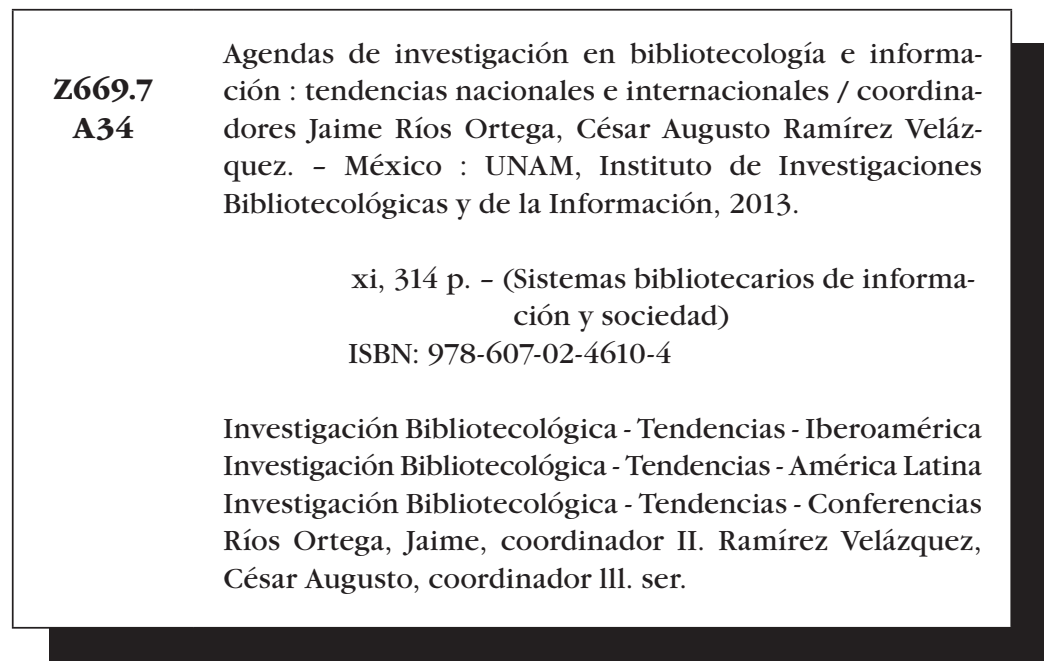

Diseño de portada: Mario Ocampo Chávez

Imagen de portada: Ignacio Rodríguez Sánchez

Primera edición, 2013

D.R. (C) Universidad Nacional Autónoma de México

Ciudad Universitaria, 04510, México D.F.

Impreso y hecho en México

ISBN: 978-607-02-4610-4 


\section{Tabla de contenido}

Presentación ...................... . . . . Jaime Ríos Ortega

Tradiciones de investigación en ciencias y humanidades $\ldots \ldots \ldots \ldots 1$ Ambrosio Velasco Gómez

Acercamiento al estudio sobre el mercado de los profesionales

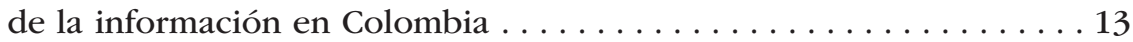
Orlanda Jaramillo y María Teresa Múnera T.

Perspectiva del mercado laboral y la percepción de la profesión bibliotecológica en Costa Rica . . . . . . . . . . . . . 25

Karla Rodríguez Salas

Profesionales de la documentación en España: ¿qué demandan

los mercados? . . . . . . . . . . . . . . . . . . . . . . . . . . 39

Juan Carlos Marcos Recio

El depósito legal en la protección de los bienes documentales: estado actual y cambios deseables . . . . . . . . . . . 63 Juan Escobedo Romero y Martín Ángel Cervantes Acosta

Desarrollo e impacto de las bibliotecas públicas en México y Colombia . . . . . . . . . . . . . . . . . . . . . . . . 75

Federico Hernández Pacheco

Investigación aplicada a la preservación y organización de documentos institucionales: la unam un mundo

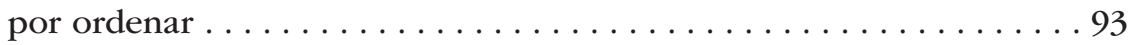

Brenda Cabral 
Perspectivas de análisis de las competencias tecnológicas en la formación de profesionales en ciencias de la información . . . . . . . . . . . . . . . . . . 111 Julio César Rivera Aguilera y Luis Roberto Rivera Aguilera

La investigación sociológica de la ciencia.Una experiencia de trabajo de campo y consulta de archivos sobre el desarrollo de la astronomía en México . . . . . . . . . . . . . . 125 Jorge Bartolucci

Las competencias en los planes de estudio de Ciencias de la Información: análisis de escenarios . . . . . . . . . . . 141 Rosa María Martínez Rider

Problemáticas sobre los lectores y la lectura en el horizonte de la investigación bibliotecológica y de la Información . . . . . . . . . . . . . . . . . . . 163 Elsa Margarita Ramírez Leyva

De la cultura escrita a la cultura visual: problemas epistemológicos . . . . . . . . . . . . . . . . . . . . . . 177

Héctor Guillermo Alfaro López

El proyecto Interpares: un modelo de investigación archivística colaborativo, multinacional y transdisciplinario . . . . . . . . . 187 Juan Voutssas M.

La Metría de la Información y del Conocimiento Científico: elementos constitutivos para el diseño de una Agenda de Investigación . . . . . . . . . . . . . . . . . . . . . . . . . 209 Salvador Gorbea-Portal y Jane Margaret Russell-Barnard

El uso de la información y la alfabetización informativa . . . . . . 241 Patricia Hernández Salazar 
La educación a distancia en bibliotecología en México

y América Latina: elementos para una agenda

de investigación . . . . . . . . . . . . . . . . . . . . . . . . 277

Roberto Garduño

El Programa de Tutorías en la agenda de investigación

institucional para la formación en ciencias de la información:

experiencia de la Escuela de Ciencias de la Información

de la Universidad Autónoma de San Luis Potosí . . . . . . . . . . . . . . 297

Guadalupe Patricia Ramos Fandiño

Beatriz Rodríguez Sierra

La desigualdad en el uso de la información en las comunidades

indígenas: una línea de investigación pertinente . . . . . . . . . . 307

César Augusto Ramírez Velázquez 


\section{Presentación}

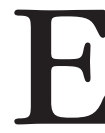

sta obra conjunta a investigadores, docentes y académicos de diversas entidades vinculadas con la bibliotecología, la documentación y los estudios de información. En ella se presentan y se profundizan temas que integran las agendas de investigación nacionales e internacionales a partir de un riguroso abordaje metodológico. La mayoría de los trabajos presentados constituye los capítulos de este libro, que reseña la fructífera travesía de los participantes nacionales y extranjeros así como sus acertadas intervenciones.

Las tendencias nacionales e internacionales de investigación discutidas se centraron en la situación del mercado laboral, la percepción social y la formación de los diferentes profesionales de la información documental: bibliotecólogos, bibliotecónomos, archivónomos, documentalistas o cualquier otra denominación dependiendo del contexto de cada país. Se acercó la mirada a cuestiones de lectura y lectores, de la cultura escrita y audiovisual y del uso de la información desde enfoques epistemológicos, culturales y sociales; también se abordaron temas propios del área, como la organización y preservación documental, el depósito legal y la protección de bienes documentales, la metría de la información, la colaboración multinacional 
y transdisciplinaria en la investigación archivística y el desarrollo e impacto de las bibliotecas públicas. Con esto, los autores ofrecen su aportación para el pleno desarrollo y reconocimiento de nuestra área del conocimiento. Se trata de contribuciones precisas en proyectos que benefician a las instituciones en las cuales se realizan.

En el primer texto, Ambrosio Velasco aborda las tradiciones que guían y permean el exhaustivo proceso de investigación en las disciplinas humanísticas y sociales, dentro de las cuales se halla la investigación bibliotecológica y de la información. En seguida, Orlanda Jaramillo presenta un estudio sobre el mercado de los profesionales de la información en Colombia; Karla Rodríguez expone su perspectiva del mercado laboral y de la profesión bibliotecológica en Costa Rica y Juan Carlos Marcos Recio indaga las demandas que los mercados laborales en España plantean a los profesionales de la documentación. En el ámbito nacional, la formación de los profesionales de la información ocupa las reflexiones de Julio César Rivera Aguilera y Luis Roberto Rivera Aguilera, de la UASLP, que analizaron este tema y enfatizaron las competencias tecnológicas requeridas. La base de sus discusiones yace en las sesiones cerradas del Seminario de Investigación sobre Educación Bibliotecológica.

Se aborda asimismo el estado actual y los cambios deseables del depósito legal para la plena protección de los bienes documentales en México, texto cuya autoría compartida pertenece a Juan Escobedo Romero y a Martín Ángel Cervantes Acosta. Continuando con la participación de instituciones en la dinámica social, Federico Hernández Pacheco dedica su trabajo al desarrollo e impacto comparado de las bibliotecas públicas en México y Colombia.

César Augusto Ramírez Velázquez propone destinar una línea de investigación pertinente al fenómeno de la desigualdad en el uso de la información en las comunidades indígenas; mientras que la preservación y organización de documentos institucionales es el tema que desarrolla Brenda Cabral y lo traslada a la situación en la UNAM como una pertinente investigación aplicada. Por su parte, Juan Voutssás expone en su escrito el modelo colaborativo, multinacional y transdisciplinario que orienta la investigación archivística en el Proyecto InterPARES. 
En un capítulo conjunto, los especialistas en Investigación sobre Metría de la Información, Jane Margaret Russell Barnard y Salvador Gorbea Portal, definen los elementos constitutivos para el diseño de una agenda de investigación en dicha disciplina, relacionada con el conocimiento científico.

Patricia Hernández delinea en su trabajo aquellas estrategias a considerar en la alfabetización informativa, considerando siempre el contexto que permea a la educación básica en México, y Roberto Garduño esboza los elementos necesarios que conforman una propuesta de investigación de acuerdo con el estado de la educación bibliotecológica a distancia en México y América Latina. En relación con esto, la exposición del programa de tutorías de la UASLP que brindan Guadalupe Patricia Ramos Fandiño y Beatriz Rodríguez Sierra se presenta como una agenda ya consolidada de investigación institucional para el aprendizaje en ciencias de la información. Aunado a esto, Rosa María Martínez Rider indaga acerca de las competencias en los planes de estudio en ciencias de la información y analizó los posibles escenarios.

Rosa Elba Chacón Escobar se enfoca en las tendencias educativas de la Universidad Autónoma de Chiapas y su abordaje académico como investigación bibliotecológica de la Dirección de Desarrollo Bibliotecario de la Unach. La discusión acerca de los procesos intrínsecos en la lectura y la escritura es planteada por Elsa Margarita Ramírez Leyva, quien ahonda en las problemáticas sobre los lectores y la lectura en el horizonte de la investigación bibliotecológica y de la información. Finalmente, Héctor Guillermo Alfaro López reflexiona acerca de los problemas epistemológicos entre la cultura escrita y la cultura audiovisual.

Jaime Ríos Ortega 


\title{
Tradiciones de investigación en ciencias y humanidades
}

\author{
Ambrosio Velasco Gómez \\ Universidad Nacional Autónoma de México
}

\section{INTRODUCCIÓN: LAS DOS CULTURAS}

T a apelación a un riguroso método racional para justificar con certeza todo auténtico conocimiento implica la renuncia a toda herencia cultural de las tradiciones y costumbres. Por eso señala con razón Alain Touraine que "la concepción occidental más rigurosa de la modernidad, la que tuvo efectos más profundos, afirmaba que la racionalidad imponía la destrucción de los vínculos sociales, de los sentimientos, de las costumbres y de las creencias llamadas tradicionales...".

La incompatibilidad entre la racionalidad metódica de la modernidad y el conocimiento tradicional tuvo entre sus consecuencias una profunda separación entre las ciencias y las humanidades, pues estas últimas se basan en el cultivo, rescate y apropiación reflexiva de los saberes heredados por las tradiciones. Por ello Descartes desechó las disciplinas humanísticas, especialmente la historia, la filología y la retórica, ${ }^{2}$ y por esta misma razón, Vico opuso la sabiduría de los antiguos a la ciencia moderna de Descartes. La oposición entre la racionalidad de las

1 Alain Touraine, Crítica a la Modernidad, México, FCE, 1998, p. 18.

2 Sobre la oposición entre racionalismo y tradiciones humanistas, véase Ernesto Grassi, La Filosofía del Humanismo, Barcelona, Anthropos, 1993, cap. 1. 
ciencias y de la filosofía respecto a las tradiciones científicas ha desembocado en lo que P. C. Snow llamó "las dos culturas". A la cultura científica y tecnológica la distingue el recurso de métodos racionales y rigurosos, mientras que las humanidades y las artes carecen de método racional, y dan prioridad al estudio de la tradición y a la libre creación.

De acuerdo con esta visión de la racionalidad, las ciencias, especialmente las matemáticas y la física, son las de mayor jerarquía pues se caracterizan por un lenguaje unívoco, preciso, de consenso en toda la comunidad científica que, en conjunción con métodos rigurosos, posibilita demostraciones y comprobaciones concluyentes. Por esta razón son consideradas las disciplinas más objetivas y racionales. En oposición a este ideal de racionalidad y objetividad se ubican las humanidades, y en especial las artes, donde impera la subjetividad, la equivocidad del lenguaje, la continua polémica sobre conceptos fundamentales de cada disciplina, y además se carece absolutamente de métodos rigurosos que la constriñan. Entre estos dos extremos las ciencias sociales ocuparían un lugar intermedio, pues utilizan métodos como la comprensión que dependen de habilidades subjetivas y, por ende, no rinden un conocimiento plenamente objetivo.

Desde finales del siglo XVIII los movimientos románticos han confrontado la arrogancia del racionalismo metódico ensalzando el sentimiento, la emoción y la espontaneidad como fuente de la creatividad artística. Así, se agudizó la confrontación, el valor de la objetividad, producto de la razón metódica, con el valor de la creatividad y el descubrimiento, resultado de capacidades artísticas irracionales. ${ }^{3}$

La tenacidad de la oposición entre ciencias y humanidades se refuerza también con los desarrollos metodológicos de las cien-

3 Gadamer señala claramente como la crítica romántica a la Ilustración moderna, comparte con ella el prejuicio de la oposición entre razón y tradición, "y se limita a invertir su valoración intentando hacer valer lo viejo como viejo [...] pero también la sencillez de la vida campesina y la cercanía con la naturaleza”. Hans G. Gadamer, Verdad y Método, Salamanca, Ediciones Sígueme, 1974 , p. 369. 
cias sociales. No sólo las propuestas metodológicas de Durkheim y John Stuart Mill, en la vertiente naturalista, sino también las de Dilthey y Max Weber en la tradición hermenéutica aspiran a consolidar el prestigio de las ciencias sociales de acuerdo con las exigencias metodológicas de las ciencias naturales. Si bien la tradición hermenéutica busca proponer métodos específicos para las ciencias de la cultura, que difieren de los métodos explicativos de las ciencias naturales, al final de cuentas busca salvar la objetividad y racionalidad de las ciencias de la cultura recurriendo a métodos rigurosos. Por eso, con razón, observa Gadamer que la propuesta hermenéutica de Dilthey es la sublimación de la concepción metodológica de la racionalidad desarrollada desde el siglo XVII en el campo de las ciencias naturales. ${ }^{4}$

En contraste con el racionalismo moderno, la tradición humanista moderna que se forjó en el siglo XVI con autores renacentistas como Pico de la Mirándola, Marsilio Ficino, Maquiavelo, Bruno, Erasmo, Luis Vives, Vitoria, Montaigne, por citar sólo a algunos, y que posteriormente reivindicó Vico frente a la ciencia y a la filosofía cartesiana, defendió una concepción histórica del saber que se desarrolla a través de la recepción e interpretación crítica e innovadora de las tradiciones heredadas del pasado. Tradición e interpretación creativa y convincente son los principales recursos con que cuenta el hombre para desarrollar el conocimiento. Para ello es indispensable el diálogo con los antiguos a través de sus textos, lo cual es fundamental para recuperar el saber históricamente acumulado y poder pararse sobre

4 "La esencia del método experimental es elevarse por encima de la contingencia subjetiva de la observación y con ayuda de esto se llega a reconocer la regularidad de la naturaleza. Las ciencias del espíritu intentan también elevarse por encima de la contingencia subjetiva del propio punto de partida y de la tradición que le es asequible y alcanzar así la objetividad del conocimiento histórico", H. G. Gadamer, Verdad y Método, p. 297-298. 
sus hombros para descubrir y crear, a través del ingenio, ${ }^{5}$ nuevos conocimientos $\mathrm{y}$ artefactos que enriquezcan las tradiciones y les permitan progresar. Por ello en el campo de la humanidades, como señala José Gaos, las tradiciones son indispensables porque proporcionan "Un mínimo siquiera de continuidad, de unidad, no sólo nominal, sino real, de tradición [...] creación de determinación y libertad -de tradición creadora o de tradicional creación". 6

En oposición a la tradición humanista, la concepción de las ciencias desarrolladas a partir de Descartes y Newton cuestionan la validez de la tradición y cifran el fundamento de la racionalidad científica en el recurso a métodos rigurosos de análisis y comprobación, donde no tiene lugar el ingenio o capacidad inventiva de las personas.

\section{TRADICIÓN Y RACIONALIDAD CIENTÍFICA}

Después de Vico, el cuestionamiento más radical a la oposición entre ciencias y humanidades se desarrolló a partir de la misma filosofía de las ciencias y no tanto de las humanidades y las ciencias sociales. Este cuestionamiento se basa en la revisión crítica de los dos presupuestos fundamentales de la concepción moderna de las ciencias que acabamos de describir: la centralidad de un método riguroso de comprobación o justificación de las hipótesis y el rechazo al conocimiento del pasado, trasmitido por las tradiciones.

5 El concepto de ingenio es central en el humanismo renacentista, pues se refiere a la actividad creadora y descrubridora, al ars inveniendi que se distingue de la ratio, que es la fuente del ars judicandi que busca la demostración. Sobre este punto, ver el análisis de Juan Luis Vives que hace en su libro ya citado Ernesto Grassi, La filosofía del humanismo, pp. 111-120.

6 José Gaos, "El pensamiento hispano-americano", en Pensamiento de lengua española. Pensamiento español, Obras Completas, Tomo VI, México, Universidad Nacional Autónoma de México, 1990, p. 40. 
Popper también reconoce el carácter tradicional de la ciencia, gracias al cual puede haber progreso científico. De otra manera no se podría rescatar el reconocimiento históricamente acumulado, y estaríamos en la misma situación de Adán y Eva. Además, Popper concibe la racionalidad de la ciencia de manera análoga a como Nicolás de Cusa la entendía: como sustitución continua de hipótesis cada vez más exactas, sin que jamás se llegue a una demostración concluyente. En este proceso, el ingenio, la capacidad creadora para formular nuevas hipótesis es tan importante o más que las pruebas a las que se somete. En todo caso, la comprobación tiene el propósito de mostrar el error de las hipótesis existentes, para dar lugar a la formulación de otras nuevas. La sucesión continua de hipótesis constituye la expansión infinita del conocimiento humano que sólo se devela a aquel que reconoce los límites de la razón humana o, en palabras de Nicolás de Cusa, a aquel que reconoce la "docta ignorancia". 7

Para Popper, el progreso de la tradición consiste precisamente en esto: que se recupere el contenido de verdad relativa de las teorías heredadas del pasado, pero que también se detecten los contenidos de falsead y se elimina progresivamente por medio de hipótesis innovadoras y arriesgadas que lleven al descubrimiento de nuevos hechos y procesos. ${ }^{8}$

Si bien Popper reconoce que la invención de hipótesis para guiar el descubrimiento es una parte esencial de la investigación científica, él se mantiene en la idea de que la creatividad y la invención es una capacidad irracional que carece de método riguroso. ${ }^{9}$ La racionalidad de la ciencia comienza con la prueba

7 Sobre el concepto de "docta ignorancia" y sus consecuencias para una teoría falibalista del conocimiento, véase Ernest Cassirer, El problema del conocimiento, México, FCE, 1965, Vol. I, cap. 1, especialmente pp., 69-71.

8 Véase especialmente su concepto de verosimilitud, expresado en el capítulo $\mathrm{x}$ de su libro El desarrollo del conocimiento objetivo. Conjeturas y Refutaciones.

9 "No existe un método lógico para tener nuevas ideas, ni una reconstrucción lógica de ese proceso... todo descubrimiento contiene un elemento irracional o una intuición creadora en el sentido de Bergson" (K. R. Popper, La lógica de investigación científica, Madrid, Tecnos, 1973, p. 31). 
empírica de la hipótesis a través del modus tollens de la lógica deductiva. Esta visión esquizofrénica de la ciencia, constituida por una parte irracional referente al proceso de creación de nuevas hipótesis y otra parte racional relativa a la contrastación metodológica de la hipótesis, originó en la filosofía de la ciencia de la primera mitad del siglo xx la famosa distinción entre el contexto de descubrimiento (creación libre de hipótesis) y el contexto de justificación (comprobación metodológica), y ha correspondido a la filosofía de la ciencia el estudio del primer contexto.

Así pues, filósofos como Popper reconocen la matriz común de la creatividad en las ciencias y en las artes, pero, lejos de desarrollar lo que hay de común y promover una cultura unificada, se apegan al credo racionalista moderno de distinguir y jerarquizar las creaciones culturales de acuerdo con su grado de justificación módica.

Al enfatizar la función creativa y descubridora de la heurística sobre la mera función de justificación de teorías e hipótesis, necesariamente ocurrió también un cambio de atención de las hipótesis y teorías aisladamente consideradas a las unidades de análisis holísticas y dinámicas. Por ello no es casual que, paralelamente a la reivindicación de la heurística en las ciencias, también se rehabilitó el concepto de tradición para referirse al contexto del desarrollo histórico de los productos y actividades científicas. En resumen, el concepto de tradición subraya la historicidad de las disciplinas científicas que progresan paulatinamente gracias a la crítica e innovación continua a las que alude el concepto de heurística.

Larry Laudan también ha destacado el papel heurístico de las tradiciones de investigación científica, en cuanto que "proporcionan directrices heurísticas para la creación o modificación de teorías específicas". ${ }^{10}$ Además, de una manera más explícita, considera que el potencial heurístico de una tradición de investigación para guiar el descubrimiento de nuevos hechos, plantear nuevos problemas y formular soluciones innovadoras es un valor

10 Larry Laudan, El progreso y sus problemas, Madrid, Edic. Encuentro, 1986, p. 131. 
cognoscitivo en sí mismo, diferente y autónomo al valor de corroboración o adecuación empírica. ${ }^{11}$

Desde otra perspectiva, este tipo de razonamiento ha sido estudiado por autores como Stephen Toulmin y Perelman dentro del ámbito de la retórica. La denominada nueva retórica trata de reivindicar tipos de argumentación que difieren de la demostración deductiva y de la comprobación empírica pero que tienen una función persuasiva muy importante en el ámbito de la ética, la política y en general de las humanidades. En años más recientes también se ha ampliado el ámbito del razonamiento retórico a las ciencias duras. Los trabajos de Steve Fuller son una clara expresión del llamado "giro retórico" en la filosofía de las ciencias. Desde estas perspectivas parecen recobran fuerza la metodología heurística frente a la demostrativa y la argumentación dialéctica y retórica, frente a la creencia dogmática en los poderes omnipotentes de la metodología.

\section{HEURÍSTICA Y TRADICIÓN EN LAS HUMANIDADES}

En el campo de las humanidades, específicamente en el de la experiencia estética y de la interpretación de la cultura, Gadamer ha mostrado que la comprensión de una obra artística, o en general de cualquier expresión cultural, parte siempre de un conjunto de prejuicios que orientan de antemano nuestra interpretación. Estos prejuicios constituyen la situación hermenéutica del intérprete. Esta situación, si bien marca los límites de lo que podemos interpretar, también define un horizonte que nos permite ver más allá de nuestro entorno familiar y cotidiano. En este sentido, los prejuicios constituyen medios para acceder a contenidos y significados no manifiestos que pertenecen a otras culturas o auto-

11 A diferencia de sus antecesores, Laudan distingue dos contextos de evaluación de las teorías y las tradiciones de investigación científicas: El contexto de adecuación empírica (corroboración o confirmación empíricas) y el contexto heurístico de "búsqueda prospectiva" (pursuit). Cfr, ibídem, cap. III. 
res con otros horizontes hermenéuticos, con otros prejuicios. Así pues, la comprensión constituye un encuentro o fusión de horizontes distintos y distantes, a través del cual se descubren nuevos significados, nuevas experiencias, nuevos valores que confrontan e interpelan nuestros prejuicios más familiares y afianzados. En este sentido el valor de una interpretación está en su capacidad para descubrir, develar lo que estaba oculto y permanecía escondido para nosotros. Gadamer hace notar que es precisamente este valor heurístico del descubrimiento lo que constituía para los antiguos griegos el significado original de verdad, que ellos denominaban aletheia. ${ }^{12}$ Esta asociación entre descubrimiento y verdad representa un reconocimiento de que el valor heurístico de una interpretación o teoría no sólo es un valor cognoscitivo alternativo a la verdad (entendida como adecuación empírica de la teoría) sino que es la verdad misma. De esta manera, la verdad entendida como aletheia, como desocultamiento, constituye el valor epistémico fundamental.

La comprensión es pues un proceso heurístico que descubre o devela nuevos significados y voces de la tradición a la que pertenecemos y, gracias a ello, se puede establecer un diálogo plural para cuestionar y revisar nuestros presupuestos más firmes. ${ }^{13}$ Este tipo de contrastación no puede resolverse a través de metodología algorítmica alguna. La decisión sobre si mantenemos nuestros prejuicios habilítales o los sustituimos por otros presupuestos rescatados del pasado o de otra cultura, es una decisión prudencial, que no puede demostrarse, ni está libre de error. En sentido estricto se trata de un razonamiento heurístico no demostrativo, ni algorítmico.

Esta misma idea de evaluación y crítica racional de las tradiciones ha sido desarrollada en el ámbito de la teoría moral

12 Cfr. Hans G. Gadamer, “¿Qué es la verdad?” en su libro Verdad y Método II, Salamanca, Editorial Sígueme, 1994, p. 53.

13 Cfr. Hans G. Gadamer, Verdad y Método, Editorial Sígueme, Salamanca 1977, especialmente caps. 9, 10 y 11. 
y de la teoría política por Alasdair MacIntyre. ${ }^{14}$ MacIntyre defiende la tesis de que los presupuestos fundamentales de una tradición así como sus teorías e interpretaciones pueden ser evaluados críticamente a través de controversias internas a la misma tradición (problemática) o de controversias externas con otras tradiciones rivales (crisis epistemológicas). Este segundo tipo de controversias exige un proceso interpretativo del lenguaje y formas de argumentación de las tradiciones ajenas, que supere los problemas de inconmensurabilidad que necesariamente surgen; pero precisamente gracias a este esfuerzo hermenéutico se pueden descubrir nuevos contenidos semánticos, teóricos, axiológicos, epistemológicos, metodológicos, etcétera, que confrontan e interpelan los presupuestos fundamentales de nuestra propia tradición, que nos obliga a formular mejores argumentos para defender, modificar o sustituir tales presupuestos. ${ }^{15}$

Tanto en Gadamer como en MacIntyre, un criterio fundamental para evaluar y elegir entre presupuestos y teorías alternativas de tradiciones en competencia es precisamente su capacidad para continuar descubriendo o develando nuevos significados, nuevos problemas y nuevas hipótesis que permitan seguir el diálogo crítico inter e intra-tradicional. Así pues, análogamente a lo que sucede en el ámbito de la filosofía de la ciencia, Gadamer y MacIntyre coinciden en reconocer a la heurística tanto como un recurso interpretativo, como el valor principal de las interpretaciones.

14 Cfr. Alasdair MacIntyre, Whose justice? Which Rationality? University of Notre Dame Press, Notre Dame, 1988, caps. XVIII y XIX.

15 "Solamente aquéllos cuya tradición posibilita que su hegemonía sea puesta en cuestión pueden tener garantías racionales para sostener tal hegemonía. Y solamente aquellas tradiciones cuyos adherentes reconocen la posibilidad de intraducibilidad en su propio lenguaje en uso son capaces de tratar adecuadamente con esa posibilidad de cuestionamiento". Alasdair MacIntyre, op. cit., cap. XIX, p. 388, admite la posibilidad de que su hegemonía sea puesta en cuestión, pueden tener garantías racionales para sostener tal hegemonía. Y solamente aquellas tradiciones cuyos adherentes reconocen la posibilidad de intraducibilidad en su propio lenguaje en uso son capaces de tratar adecuadamente con esa posibilidad de cuestionamiento". Alasdair MacIntyre, op. cit., cap. XIX, p. 388. 


\section{CONCLUSIONES}

La separación y jerarquización de las ciencias y las humanidades se originó a partir de la concepción moderna de las ciencias iniciadas por Descartes y Newton en el siglo XVII. Esta concepción del conocimiento científico enfatizaba el apego estricto a una metodología que garantizara la objetividad y racionalidad del conocimiento, y rechazaba los antiguos procedimientos de los humanistas basados en la interpretación de la tradición y el ingenio creativo del humanista, que le permitan realizar innovaciones para enriquecer y desarrollar la tradición en que se había formado. Así, durante la ilustración moderna las ciencias se presentaron como la expresión más refinada de la racionalidad humana, mientras que a las humanidades se les consideraba como una forma de saber todavía no liberadas de la autoridad del pasado.

El cuestionamiento a esta dicotomía entre ciencias y humanidades partió precisamente del rechazo de la suficiencia de la metodología para justificar racionalmente la elección de teorías e hipótesis. Los filósofos de la ciencia de principios del siglo Xx como Pierre Duhem, Otto Neurath, entre otros, consideraron indispensable el recurso a razonamientos prácticos, de carácter prudencial, para elegir entre hipótesis alternativas. Además, estos mismos filósofos reconocieron que la oposición entre ciencia y tradición es un absurdo, pues la ciencia misma es una tradición que se desarrolla paulatinamente a través de las innovaciones.

Si comparamos las tradiciones científicas y las humanísticas encontramos interesantes relaciones de convergencia y complementariedad. La convergencia fundamental es que en ambos tipos de tradiciones la heurística es tanto un medio o recurso (metodológico o hermenéutico) como un valor o fin (el descubrimiento y la innovación), y en ambos tipos de tradiciones la relación entre fines y medios se refuerzan recíprocamente.

Por otra parte, en la medida en que las teorías e interpretaciones que conforman una tradición tienen un mayor valor heurístico (o son heurísticamente más verosímiles), también aumenta la capacidad de la tradición para comprender dialógicamente nue- 
vos significados y contenidos de tradiciones ajenas. Por ello, la heurística como recurso hermenéutico y la heurística como valor fundamental y criterio de evaluación de las interpretaciones se refuerzan recíprocamente en un círculo virtuoso, que parafraseando la expresión de Dilthey (círculo hermenéutico), podemos denominar "círculo heurístico".

Otro punto muy importante de convergencia es la relevancia del diálogo y la racionalidad prudencial, que lejos de ser formas débiles de la racionalidad peculiares de las humanidades, de la ética y de la política, constituyen la forma de racionalidad más importante, tanto en las tradiciones intelectuales (científicas y humanísticas), como en las tradiciones morales y políticas. Así pues, la racionalidad práctica prudencial que se pone de manifiesto en el círculo heurístico se puede postular como un nuevo paradigma de racionalidad, en sustitución de la desgastada racionalidad algorítmica y demostrativa que ha mostrado su inoperancia aun en las ciencias naturales. A este tipo de racionalidad prudencial le es afín una argumentación retórica que inclina a la persuasión, sin necesidad de la demostración o comprobación concluyente.

Gracias a la retórica persuasiva es posible reestablecer temporalmente los consensos al interior de la tradición que tanto la pasión heurística (Polanyi) como la interpretación dialógica de tradiciones ajenas (Gadamer y MacIntyre) ponen en cuestionamiento. La alternancia sucesiva de crítica heurística innovadora y reestablecimiento de consensos por medios de argumentación retórica constituye otra fase o aspecto del círculo heurístico a través del cual se asegura la continuidad progresiva al interior de una tradición o entre tradiciones sucesivas.

Por otra parte, la principal relación de complementariedad entre las tradiciones científicas y en las tradiciones humanísticas se refiere a la dimensión metodológica de la heurística que enfatizan los filósofos de la ciencia (principalmente Lakatos) y su función comprensiva o hermenéutica que señalan tanto Gadamer como MacIntyre. Los filósofos de la ciencia no reflexionan suficientemente como lo hacen los hermeneutas sobre las condiciones que posibilitan la comprensión de tradiciones ajenas y 
su importancia como principal fuente crítica de innovación en la propia tradición. Por otra parte, los hermeneutas no han prestado suficiente atención a las concepciones heurísticas de la metodología que han analizado los filósofos de la ciencia contemporánea; esta concepción que desecha y sustituye la vieja idea de la metodología algorítmica y demostrativa a la que se oponía la filosofía hermenéutica. Así pues, a lo que apunta esta complementariedad es a una "hermeneutización" de la metodología de las ciencias y a una "metodologización" heurística de la hermenéutica.

Finalmente, el último tópico de complementariedad que quiero resaltar se refiere a los aspectos individuales y comunitarios de la dos tradiciones: mientras que Polanyi hace énfasis en la pasión heurística como una fuerza interior en cada científico, que le impele a cuestionar los marcos conceptuales heredados y aceptados en la tradición científica a la que pertenece, Gadamer subraya la fuerza que tienen sobre el individuo esos marcos que son aceptados por toda una comunidad y que constituyen el sensus communis que limita el tipo de argumentos, creencias y principios que pueden ser razonablemente aceptables. La complementariedad que yo percibo entre estos dos enfoques apunta a un equilibrio entre el riesgo iconoclasta, solipsista e inclusive de irracionalidad que está latente en la concepción de Polanyi, y el riesgo conservador y asfixiante de la autonomía personal del sujeto bajo el peso de la tradición. 


\title{
Acercamiento al estudio sobre el mercado de los profesionales de la información en Colombia
}

\author{
Orlanda Jaramillo y María Teresa Múnera T. \\ Universidad de Antioquia, Colombia
}

\section{INTRODUCCIÓN}

1 contexto actual muestra la indisoluble relación entre for-
mación y mercado laboral y, en consecuencia, el papel que
el campo laboral juega en las competencias de los egresados, la cuales se hacen visibles en el desempeño de los profesionales, y es el mercado laboral el que define su calidad, pertinencia y suficiencia. Este conocimiento del mercado laboral de los profesionales de la información es una preocupación compartida tanto por la Academia como por las Asociaciones profesionales, las cuales pretenden mostrar su pertinencia y vigencia social para responder adecuadamente al desarrollo que reclama la profesión, desde la mirada al entorno o medio laboral, a las necesidades del mercado y a la identidad que el programa o la institución de educación les imprimen a sus profesionales.

El presente escrito da cuenta de la revisión de los 20 trabajos relacionados con el mercado laboral de los profesionales de la información, para lo cual se incluyó el tema de la formación y el perfil del profesional del área. En consecuencia, esta revisión permitió un acercamiento al contexto actual de la profesión to- 
mando en cuenta los resultados del mercado laboral, los perfiles profesionales, las perspectivas y las tendencias de la formación en el área de la ciencia de la información en Colombia.

\section{EL DESEMPEÑO LABORAL DE LOS PROFESIONALES DE LA INFORMACIÓN Y LA FORMACIÓN,} UNA RELACIÓN INSEPARABLE.

EL CASO COLOMBIANO

En Colombia, de acuerdo con la Ley 30 de 1992, la educación superior es un proceso permanente que posibilita el desarrollo de las potencialidades del ser humano de una manera integral, y que se realiza con posterioridad a la educación media o secundaria y tiene por objeto el pleno desarrollo de los alumnos y su formación académica o profesional; ${ }^{1}$ y la define como un servicio público cultural, inherente a la finalidad social del Estado, cuya función esencial es "La formación integral dentro de las modalidades y calidades de la Educación Superior, capacitándolos para cumplir las funciones profesionales, investigativas y de servicio social que requiere el país", ${ }^{2}$ Como entes rectores de la educación superior, están el Consejo Nacional de Educación Superior (CESU), de carácter permanente, como organismo del Gobierno Nacional vinculado al Ministerio de Educación Nacional, con funciones de coordinación, planificación, recomendación y asesoría; por su parte, las universidades y las instituciones tecnológicas son las responsables del desarrollo de los programas de educación superior.

1 Ley 30: Por la cual se organiza el servicio público de la Educación Superior. Bogotá: Congreso de la República, 1992, p. 1. (http://www.secretariasenado. gov.co/senado/basedoc/ley/1992/ley_0030_1992.html)

2 Ídem. 
En el caso concreto de la formación de profesionales de la información, ${ }^{3}$ ésta data de 1956 y es un sector que cada vez se consolida más en la oferta de programas tanto en el nivel tecnológico, profesional, como de postgrado (especialización y maestría). En términos generales, tanto las iniciativas como las ofertas de formación han respondido a la carencia de profesionales y de personal calificado en el área de la información, y ha sido claro su propósito de formar profesionales que respondan a las necesidades de información del país, especialmente las relacionadas con el desarrollo científico, cultural, educativo y económico.

En la actualidad, el perfil del profesional de la información está determinado por los desafíos de la Sociedad de la Información; por eso, los planes de estudio deben estar orientados a enfrentar los desafíos de esta sociedad y los retos que la sociedad, cada vez más globalizada e internacionalizada, exige y reclama. Pero también debe comprometer lo anterior a los profesionales a consolidar una comunidad bibliotecológica que reflexione sobre los conocimientos y saberes de las disciplinas que hacen parte de la ciencia de la información, en especial el desarrollo conceptual alcanzado por estas disciplinas (tarea innegable e impostergable para las Instituciones de educación superior responsables de la formación de estos profesionales).

La formación de profesionales de la información la realizan las siguientes instituciones de educación superior:

- Universidad de Antioquia, Escuela Interamericana de Bibliotecología, Programa de Bibliotecología, 1956. Su fin es formar profesionales líderes en el manejo de la información, promotores culturales y generadores de conocimientos en diversos campos del saber y del ejercicio profesional, así como educadores en el uso adecuado de la información.

3 Se denomina profesionales de la información a los egresados de programas de educación superior en bibliotecología, archivística y ciencia de la información 
- Universidad de la Salle, Facultad de Ciencias Económicas y Sociales, Sistemas de Información y Documentación, 1971. Enfoca su perfil en formar profesionales integrales con un conocimiento disciplinar en bibliotecología y archivística, y un sólido componente social, investigativo, tecnológico y de gestión, permeado por el componente humanístico.

- Pontificia Universidad Javeriana, Facultad de Comunicación y Lenguaje, Departamento de Ciencia de la Información, Programa de Ciencia de la Información, Bibliotecología, 1973. Pretende formar profesionales capaces de construir y gestionar los sistemas de acceso y distribución de información, con el uso de tecnologías de punta, así como ayudar a los usuarios y creadores de modelos de desarrollo de información en las organizaciones, para que tomen parte activa en debates sobre el avance del conocimiento y política científica, y sepan desempeñarse en grandes organizaciones.

- Universidad del Quindío, Facultad de Ciencias Humanas y Bellas Artes, Programa Ciencia de la Información y la Documentación Bibliotecología y Archivística, 1986. Con énfasis en la formación de profesionales, con habilidades y competencias en el manejo de la información, buscamos desarrollarlos en agentes de verdadero cambio, que respondan adecuadamente a las necesidades de información de la sociedad de hoy.

- Fundación Universitaria INPAHU, Facultad de Ingenierías y Tecnologías de la Información, Profesional en Ciencia de la Información, 2010. Se propone formar profesionales con énfasis en la formación para planear, administrar, asesorar, evaluar y proyectar las unidades de información, y que tengan capacidad de análisis, síntesis y resolución de problemas para también diseñar y suministrar productos y servicios de información bibliográfica, documental y archivística que estén de acuerdo con normas nacionales e 
internacionales y utilicen las tecnologías de la información, con responsabilidad social y ciudadana, para contribuir al desarrollo social, educativo, cultural y económico del país.

\begin{tabular}{|c|c|c|}
\hline $\begin{array}{l}\text { Universidad. Énfasis de la } \\
\text { formación }\end{array}$ & Programa & Título \\
\hline \multirow{5}{*}{$\begin{array}{l}\text { Universidad de Antioquia. Medellín. } \\
\text { Énfasis: formación social y cultural } \\
\text { teniendo como eje de su formación } \\
\text { la investigación. }\end{array}$} & Magíster & Magíster en Ciencia de la Información \\
\hline & Especialización & $\begin{array}{l}\text { Especialista en gerencia de servicios } \\
\text { de información }\end{array}$ \\
\hline & Especialización & Especialista en edición \\
\hline & Profesional & Bibliotecólogo \\
\hline & Tecnología & Archivística \\
\hline \multirow{3}{*}{$\begin{array}{l}\text { Universidad de La Salle. Bogotá. } \\
\text { Énfasis: gestión en áreas administra- } \\
\text { tivas y tecnológicas. }\end{array}$} & Magíster & Magíster en \\
\hline & Especialización & $\begin{array}{l}\text { Especialista en sistemas de información } \\
\text { y gerencia de documentos }\end{array}$ \\
\hline & Profesional & $\begin{array}{l}\text { Profesional en Sistemas de Información, } \\
\text { Bibliotecología y Archivística }\end{array}$ \\
\hline \multirow{3}{*}{$\begin{array}{l}\text { Universidad Pontifica Javeriana. } \\
\text { Bogotá. Énfasis: gerencia con } \\
\text { aplicación de nuevos modelos } \\
\text { tecnológicos y administrativos }\end{array}$} & Especialización & Especialización en Archivística \\
\hline & Especialización & $\begin{array}{l}\text { Especialización en redes de información } \\
\text { documental }\end{array}$ \\
\hline & Profesional & $\begin{array}{l}\text { Profesional en Ciencia de la Informa- } \\
\text { ción-Bibliotecología }\end{array}$ \\
\hline $\begin{array}{l}\text { Universidad del Quindío. Quindío. } \\
\text { Énfasis: Bibliotecología y archivística }\end{array}$ & Profesional & $\begin{array}{l}\text { Profesional en Ciencia de la Información } \\
\text { y la Documentación, Bibliotecología } \\
\text { y Archivística. }\end{array}$ \\
\hline \multirow{2}{*}{$\begin{array}{l}\text { Fundación Universitaria INPAHU. } \\
\text { Bogotá. Énfasis: Bibliotecología } \\
\text { y archivística }\end{array}$} & Profesional & $\begin{array}{l}\text { Profesional en Ciencia de la Información } \\
\text { y bibliotecología. }\end{array}$ \\
\hline & Tecnología & $\begin{array}{l}\text { Tecnólogo en Administración de Siste- } \\
\text { mas de información y documentación }\end{array}$ \\
\hline
\end{tabular}

En términos generales, la formación de profesionales de la información tiene como áreas centrales y comunes los diferentes programas que se ofrecen en el país: la organización y administración de sistemas y servicios de información física o virtual, la gestión del conocimiento, el diseño y prestación de servicios de información, el procesamiento y análisis de la información, áreas en las cuales se incorporan las TIC para la recuperación, conservación, organización y difusión de la información, con fines tanto 
científicos, económicos y educativos, como de desarrollo social. No obstante, cada universidad tiene su propia identidad en el perfil profesional, identidad que incluye las tendencias más significativas en los procesos de formación y en los cargos y lugares laborales con los cuales se vinculan estos profesionales.

Todos los programas ofrecidos a nivel profesional se imparten en modalidad presencial, exceptuando el de la Universidad del Quindío, el cual se ofrece en modalidad virtual. Igualmente, los programas los de la Universidad de Antioquia, La Salle y Javeriana, han obtenido la acreditación de alta calidad que otorga el Consejo Nacional de Acreditación, y por su parte el programa de la Universidad del Quindío cuenta con el Registro Calificado (estándares mínimos), expedido por el Ministerio de Educación.

La acreditación de alta calidad hace parte de los procesos de aseguramiento de la calidad de la educación superior, en consonancia con la Ley 30 de 1992: Ley de Educación Superior mediante la cual se busca garantizarle a la sociedad que las instituciones de educación superior y los programas académicos que ofrecen las mismas cumplan con altos niveles de calidad y se puedan considerar de excelencia. Para orientar, coordinar y supervisar los procesos de aseguramiento de la calidad se crea el Sistema de Acreditación, y con él el Consejo Nacional de Acreditación (CNA). Cabe advertir que estos procesos son uno de los principales instrumentos para establecer contactos con el egresado, y para conocer las características, las necesidades y las tendencias de su desempeño, además de los factores de desempleo.

\section{EXPLORACIÓN SOBRE EL MERCADO LABORAL DE LOS PROFESIONALES DE LA INFORMACIÓN EN COLOMBIA}

La formación de profesionales de la información en Colombia ha alcanzado un amplio desarrollo respaldado por la existencia de diferentes programas de educación superior en el área de la Ciencia de la Información, y por la existencia de leyes para el de 
ejercicio profesional (Ley 11 de 1979: Ley del bibliotecólogo, y el Decreto reglamentario 865 de 1988, que reglamenta la Ley el ejercicio profesional, así como la Ley 1409 de 2010: Ley de Archivos) y una mayor proyección y diversificación en el campo laboral.

El contexto laboral actual está caracterizado por el cambio continuo y es también afectado por fenómenos como la globalización y las TIC, los cuales impactan, con nuevas formas de trabajo, la flexibilidad laboral e institucional y las condiciones que el mercado de trabajo les impone a los profesionales. Como consecuencia de esta realidad laboral tanto los organismos nacionales (Ministerio de Educación) como los locales (Universidades), responsables de la política en educación superior, adelantan acciones encaminadas a enfrentar los desafíos actuales.

En el caso del ente rector del Sistema Educativo en Colombia, el Ministerio de Educación Nacional (MEN) es responsable del diseño, orientación y ejecución de las estrategias que ayuden a fomentar un sistema educativo pertinente y eficaz, como estableció en el 2006 el Observatorio Laboral para la Educación, un sistema de información que realiza el seguimiento de los graduados de la educación superior para conocer las condiciones de su inserción en el mercado laboral del país. El Observatorio tiene como finalidad impulsar la inversión y eliminar las barreras de competitividad, buscando articular a la academia con las necesidades del sector productivo, como uno de los componentes del Sistema de Aseguramiento de la Calidad. ${ }^{4}$

El seguimiento que el Observatorio realiza se hace a partir de la integración de los registros de graduados que proveen las instituciones de educación superior (IES), con los datos de los sistemas de información de los Ministerios de Protección Social y de Hacienda sobre los registros administrativos del Sistema de Seguridad Social; información que posibilita estudios sobre la perti-

4 Boletín del Observatorio del Mercado de Trabajo y la Seguridad Social, Núm. 9, Acceso:

$<$ http://www.ascolbi.org/documentos/Boletin_Observatorio_Trabajo_009_2006,pdf>. 
nencia de la educación a partir del seguimiento de los graduados en el mercado laboral con el fin de contribuir al mejoramiento de la calidad de los programas académicos ofrecidos. De esta manera, una de las acciones más destacadas del Observatorio es la aplicación, durante los años 2005-2007, de la Encuesta de seguimiento a graduados cuyo principal objetivo era conocer el grado de relación del trabajo que desempeña el graduado con su profesión, si éste considera que dicho trabajo le permite crecer y desarrollarse profesionalmente, y averiguar el tiempo transcurrido desde su graduación hasta el momento en que obtuvo su primer empleo. Lo más destacado de la encuesta de 2009 para el sector de los profesionales de la información es la ubicación de la bibliotecología como la segunda carrera con mayor demanda:

Esta es la lista completa de las 10 carreras con mayor inclusión de graduados en sus respectivos sectores económicos, según datos del Observatorio del Mercado Laboral del Ministerio de Educación. El porcentaje es el resultado del número de graduados que cotizan seguridad social, sobre el total de egresados de cada profesión durante el 2009: Bibliotecología: 94.7\%, Contaduría Pública: 82.1\%, Medicina: 81.1\%, Geología: $77.9 \%$, Ingeniería civil y afines: 77.4\%, Química: 76.4\%, Ingeniería eléctrica: $76.3 \%$, Ingeniería industrial: $74.9 \%$, Ingeniería de sistemas: $74.7 \%$, Administración de empresas: $73.9 \% 5$

Este posicionamiento se mantiene hasta el 2011 y es corroborado con el estudio Los profesionales colombianos en el Siglo XXI ¿más estudian, más ganan? realizado por la Universidad Externado de Colombia, al considerar a "La bibliotecología como una excelente opción".

En el campo local, las universidades se preocupan por ofrecer programas de formación universitaria que apuesten a la generación de nuevos conocimientos en la formación disciplinar, lo que

5 Stefano, Farné Vergara, Carlos Andrés (2008), ¿Los profesionales colombianos en el siglo XXI: más estudian, más ganan?, Bogotá: Universidad Externado de Colombia, Departamento de Seguridad Social y Mercado de Trabajo, Observatorio del Mercado de Trabajo y Seguridad Social, 2008, 24p. 
se traduce en una apuesta por el desarrollo de conocimientos específicos en el área de la bibliotecología, complementado con áreas como la administración y gerencia de mercadeo y finanzas, los servicios y las tecnologías de la información; en palabras de Zapata:

Una razón para esto tiene que ver con la necesidad de las instituciones de educación superior de ofrecer una formación que se ajuste a los cambios organizacionales en un entorno globalizado, donde la empresas requieren contar con personal que pueda desarrollar actividades técnicas propias de su área de conocimiento y al mismo tiempo ser capaz de planear y proponer innovaciones en los procesos o en los productos que afectan su quehacer, contribuyendo a generar competitividad en los resultados que produce la empresa. ${ }^{6}$

También recomienda en forma especial mantener los estándares de calidad, los cuales se hacen visibles en los procesos de aseguramiento de la calidad. De esta manera, la dinámica que caracteriza el mercado laboral de los profesionales de la información está relacionada con la formación de las universidades, y así lo demuestran los procesos de autoevaluación con fines de renovación de la acreditación de alta calidad, donde los resultados señalan cómo la formación ofrecida responde más a la necesidad de mejorar las competencias laborales y ocupacionales.

No obstante estas apreciaciones, el conocimiento de la realidad entre la oferta y demanda de los profesionales de la información en Colombia es un campo que requiere mayor exploración y un enfoque prospectivo, pues si bien en los últimos años se han realizado investigaciones, trabajos de grado y estudios sobre el tema, todos ellos muy valiosos, estos estudios han sido de corte descriptivo y retrospectivo y no han logrado niveles adecuados de articulación entre los programas y el sector empleador.

6 Carlos Alberto Zapata Cárdenas, "La oferta formativa en bibliotecología en Colombia: análisis actual del sector", en Revista Interamericana de Bibliotecología, Vol. 30 Núm. 2, Medellín, jul.-dic. 2007. 


\section{CONCLUSIONES}

El conocimiento del mercado laboral y el desempeño de la profesión es útil, tanto para determinar tendencias y ofertas como para orientar los diseños curriculares: pertinencia y vigencia social de los programas. Es así como se puede afirmar que los perfiles de las universidades colombianas con programas profesionales en bibliotecología y archivística, aunque señalan algunas tendencias específicas en los procesos de formación, éstas no afectan su desempeño en el mundo laboral; por el contrario, se puede interpretar como una fortaleza para aplicar a determinados mercados y cargos laborales.

Los estudios realizados en Colombia sobre el mercado laboral de los profesionales de información permiten visualizar elementos determinantes para la formación profesionales como son: áreas de trabajo, niveles de empleo, subempleo y de desempleo, movilidad ocupacional, cargos, competencias laborales, niveles salariales y tendencias del mercado laboral.

De igual forma, esta exploración permitió evidenciar que, aunque los estudios muestran resultados positivos sobre la ubicación laboral de estos profesionales, apreciando a la bibliotecología como una de las profesiones con mayor índice de demanda y de remuneración en la primera década del siglo XXI, en la actualidad se manifiesta un fenómeno de reducción de la demanda de profesionales en contratos a término indefinido; lo que se traduce en un incremento de la modalidad de contratación por servicios, a término fijo o por outsourcing, con salario integral, contrataciones que conllevan a niveles de rotación e inestabilidad laboral.

Una característica especial del mercado laboral de los profesionales de la información tiene que ver con la vinculación, al inicio de los estudios al sector, situación que no se corresponde con las ofertas salariales y contratos laborales a término indefinido.

Los estudios muestran que el principal sector de ubicación laboral de los profesionales de la información continúa siendo la biblioteca académica o universitaria, con una ligera variación hacía las bibliotecas públicas. También es propicio el inicio de 
creación y desarrollo de empresas dedicadas a la prestación de servicios de información.

Finalmente, se evidencia la necesidad de que las IES realicen estudios de mercado y de desempeño laboral como un instrumento para medir la relación directa que puede existir entre la calidad y pertinencia de la educación que imparten y la inserción en el mercado laboral; y como una estrategia de acompañamiento de sus egresados con el fin de afianzar su relación y de orientarlos en el proceso de inserción laboral, su cualificación en formación continuada. Es decir, contar con un mapa laboral que permita identificar campos de acción, áreas de desempeño, niveles de formación, escalas salariales y características del profesional.

\section{REFERENCIAS BIBLIOGRÁFICAS}

Colombia, Congreso de la República, Ley 30: Por la cual se organiza el servicio público de la Educación Superior. Bogotá: Congreso de la República, 1992, p. 1. Acceso: http://www.secretariasenado. gov.co/senado/bosedoc/ley/1992/ley_0030_1992.html

Colombia, Ministerio de Educación Nacional, Observatorio del Mercado de Trabajo y la Seguridad Social con base en datos ole, Boletín del Observatorio del Mercado de Trabajo y la Seguridad Social, Núm. 9. Acceso: http://www.ascolbi.org/documentos/Boletin_Observatorio_Trabajo_009_2006.pdf.

Escalona R., Lina, Formación profesional y mercado laboral: vía real hacia la certificación del bibliotecólogo, México: Centro Universitario de Investigaciones Bibliotecológicas, UNAM, 2006, pp. 19, $33,39,48$.

Escobar Alzate, Raúl, Estudio de caracterización del sector educativo en Colombia: Mesa sectorial de educación, SENA, 2003. 
Farné, Stefano; Vergara, Carlos Andrés, ¿Los profesionales colombianos en el siglo XXI más estudian, más ganan?, Universidad Externado de Colombia, Departamento de Seguridad Social y Mercado de Trabajo, Observatorio del Mercado de Trabajo y la Seguridad Social, Bogotá, 2008.

Maya Guerra, José Ignacio, Herrera Herrera, María Eugenia, "Aproximación al estado del arte sobre los estudios de desempeño de graduados de programas de educación superior", Revista Virtual Universidad Católica del Norte, Núm. 36 (may.-ago., 2012, Colombia), p. 127-157. Acceso: http://revistavirtual.ucn.edu.co/index. $\mathrm{php} /$ RevistaUCN/article/view/374/709

Tejada Artigas, Carlos; Moreiro, José Antonio, "Mercado de trabajo en Biblioteconomía y Documentación: Estudios sobre la inserción laboral de los titulados universitarios", El profesional de la información, 2003, enero-febrero, Vol. 12, Núm. 1, pp. 4-9. Acceso: http://www.elprofesionaldelainformacion.com/contenidos/2003/ enero/1.pdf

Vallejo Sierra, Ruth Helena, "La formación profesional de bibliotecólogos y archivistas: integrada, con énfasis o independiente". Acceso: http://conference.ifla.org/ifla77

Vallejo Sierra, Ruth Helena, "La bibliotecología como alternativa profesional", Trabajo de grado para obtener la suficiencia investigadora, Departamento de Bibliotecología y Documentación, Universidad de Salamanca, España, 2008, p. 346.

Zapata Cárdenas, Carlos Alberto, "La oferta formativa en bibliotecología en Colombia: análisis actual del sector", en: Revista Interamericana de Bibliotecología. Vol. 30, Núm. 2, Medellín, jul.-dic., 2007.

Zapata Cárdenas, Carlos Alberto et al., Estudio de caracterización ocupacional en archivos y bibliotecas en Colombia: situación actual del sector, Bogotá: Universidad de La Salle. 2006. 


\title{
Perspectiva del mercado laboral y la percepción de la profesión bibliotecológica en Costa Rica
}

\author{
KARLA RODRÍGUEZ SALAS \\ Universidad Nacional, Costa Rica
}

\section{INTRODUCCIÓN}

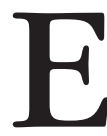

1 objetivo de este trabajo consiste en lograr un acercamiento al mercado laboral de los egresados de la carrera de bibliotecología y la percepción de ésta. Para tal tarea, se realizó una revisión y un cotejo de los datos finales obtenidos del análisis de tres investigaciones iniciadas en la Escuela de Bibliotecología, Documentación e Información de la Universidad Nacional de Costa Rica.

El objeto de estudio consiste en conocer algunos aspectos vinculados con el mercado laboral del bibliotecólogo en relación con las tareas desempeñadas, el lugar de trabajo y las competencias desarrolladas en el proceso de formación universitaria, así como con la percepción que tienen los usuarios sobre la labor desempeñada por este profesional y la carrera de bibliotecología.

Es importante considerar que el mercado de trabajo se ha incrementado no sólo por la legislación laboral sino también por la innovación curricular, específicamente lo relacionado con el desarrollo de competencias informáticas en tanto que permite crear servicios y productos de alto nivel de calidad y acceso remoto; de esta forma se amplían, renuevan y optimizan las distintas activida- 
des y servicios que tenía el bibliotecario tradicional, y se configura una "nueva imagen" del profesional de la información que estaría más acorde con las demandas de los usuarios y empleadores.

Ante esta situación de cambio constante, el mercado exige permanentemente nuevas competencias a los egresados de las carreras de bibliotecología que influyen directamente en la oferta y la demanda de trabajo del sector y, por lo tanto, tienen consecuencias inmediatas en la formación y en la evaluación de los centros de estudios, ya que esta nueva imagen requiere de mayores conocimientos tecnológicos, comunicacionales e informacionales, lo que implica un proceso de cambio en torno a la educación de las personas.

El aumento de los conocimientos que se consideran necesarios para realizar diversas actividades ha producido la necesidad de una evaluación permanente del currículo universitario. Es por eso que diferentes instituciones de educación superior se han sometido a procesos de autoevaluación con miras al mejoramiento continuo y a procesos de evaluación y acreditación, donde intervienen como actores los empleadores y usuarios directos del servicio.

Es así como las nuevas demandas informativas delinean un escenario en el mundo de la comunicación y transmisión de conocimientos. Este nuevo escenario que se le presenta al profesional de la información lo compromete a capacitarse continuamente para poder desempeñarse de forma competitiva. Para ello, tal y como lo expresa Delors (1996), aquél deberá dominar las nuevas tecnologías empleadas en actividades tradicionales, así como en otras que le permitan una comunicación constante y un mayor acercamiento con los usuarios.

\section{ANTECEDENTES}

La formación profesional de bibliotecólogos en Costa Rica se remonta al año de 1968, con la creación de la Carrera de Bibliote- 
cología y Ciencias de la Información de la Universidad de Costa Rica, y posteriormente, con la Carrera de Bibliotecología y Documentación de la Universidad Nacional en el año 1977. Décadas después, dos universidades se sumaron a la labor de formación de cuadros profesionales en el campo: la Universidad Estatal a Distancia y la Universidad Autónoma de Centroamérica.

El mercado laboral lo integraron, inicialmente, las universidades, que a falta de especialistas brindaron oportunidades de formación profesional para sus empleados. Posteriormente, la formación trascendió a las bibliotecas públicas y a las bibliotecas escolares y especializadas. Con el transcurso del tiempo, la labor bibliotecológica se abrió espacios para insertarse en un mercado emergente constituido por aquel relacionado con la provisión de servicios especializados. A partir de éste se empezaron a constituir los primeros centros de documentación y unidades especializadas de información como respuesta a la necesidad de gestionar la información científica producida en determinadas áreas del conocimiento.

Es así como hoy en día tenemos profesionales que incursionan en diferentes mercados, y a quienes se pretende dar seguimiento como parte de los procesos de evaluación y acreditación emprendidos por dos universidades estatales pioneras en la formación de profesionales de la información.

\section{OBJETIVOS}

La investigación tuvo como propósito conocer algunos aspectos relacionados con el ámbito laboral de los egresados de la carrera y la percepción del mercado con respecto a ésta.

El estudio se diseñó partiendo de los siguientes objetivos:

- Disponer de una panorámica actualizada del estado actual del mercado laboral de los profesionales en bibliotecología. 
- Conocer la percepción de los usuarios y empleadores con respecto a la profesión bibliotecológica.

- Ofrecer una prospectiva sobre el posible desarrollo y retos de la profesión.

\section{ETAPAS DE LA INVESTIGACIÓN}

La investigación se realizó siguiendo las siguientes etapas:

- El primer paso para realizar la investigación es el correspondiente a la recopilación y sistematización de información referente a los egresados de la carrera, el cual se desarrolló con una metodología participativa utilizando tanto técnicas cualitativas como cuantitativas para recopilar, describir y analizar la situación actual de manera objetiva.

Como parte de ésta, se revisaron los documentos que se obtuvieron en el proceso de autoevaluación y acreditación de las carreras, la consulta y la recopilación de información de los egresados, docentes y empleadores. Para efectos del análisis de la percepción de la carrera, se exponen algunos de los resultados obtenidos de un diagnóstico previo (Oviedo, 2011) sobre la percepción que tienen los estudiantes de secundaria sobre la carrera.

- Identificación de la población: se identificaron los profesionales mediante un registro de egresados de licenciatura, consulta de las planillas de docentes de la Universidad Nacional y de la Universidad de Costa Rica, instituciones que han sometido sus carreras a procesos de evaluación y acreditación, empleadores participantes en los procesos de evaluación y estudiantes de secundaria.

- Estratificación de la población: por las diferencias en las unidades de estudio que conforman esta población se procedió a agruparla en dos estratos claramente diferenciados, a saber: 
Perspectiva del mercado laboral y la percepción de la profesión...

El primero compuesto por los egresados insertos en el mercado laboral, compuesto por:

- 586 egresados de la carrera,

- 54 profesores de tiempo completo y parcial (21 profesores de la Universidad Nacional y 33 la Universidad de Costa Rica).

- El segundo compuesto por los usuarios de los servicios y los empleadores:

- 150 estudiantes de secundaria y

- 21 empleadores participantes en el proceso de acreditación.

\section{SELECCIÓN DE VARIABLES.}

Se trabajó con el estudio y análisis de las siguientes variables, agrupadas de la siguiente manera:

\begin{tabular}{|l|l|}
\hline \multicolumn{1}{|c|}{ Acercamiento al mercado laboral } & \multicolumn{1}{|c|}{ Estudio de opinión Percepción de la carrera } \\
\hline Ámbito de dependencia laboral & Características y grado de formación del graduado \\
\hline Lugar de trabajo & Conocimiento de la carrera \\
\hline Situación laboral & Funciones del bibliotecólogo \\
\hline Tipo de actividades en las que se desempeña. & Temas relacionados con la carrera \\
\hline Grado de dificultad para conseguir empleo & Imagen de la bibliotecología \\
\hline
\end{tabular}

\section{HALLAZGOS RELEVANTES}

Con respecto al mercado laboral se obtuvieron los siguientes resultados: 


\section{Ámbito de dependencia laboral}

Para esta pregunta se tuvo en cuenta el empleo en el que se invierte la mayor cantidad de tiempo laboral, ya sea porque se tiene más carga horaria o se está más relacionado con la profesión. Más de las tres cuartas partes de la población entrevistada ejercen en el sector público, porcentaje que coincide con las expectativas de los egresados cuando eran estudiantes. La mayoría especificaba que, como empleador, le gustaría desempeñarse en el sector público por considerar tener más oportunidades de ascenso, mayor estabilidad y oportunidades de continuar preparándose profesionalmente.

Cabe observar que no se visualizan egresados que se desempeñen en el sector independiente, específicamente en lo denominado como "venta de servicios". Se ha podido constatar que esta modalidad de trabajo está siendo desempeñada durante los primeros años de estudio, sobre todo los posteriores a la realización de la práctica profesional, cuando los estudiantes son contratados para completar los proyectos emprendidos o darle seguimiento al desarrollo de nuevos servicios.

También es rescatable que este tipo de servicios es proporcionado por empresas consolidadas cuyos profesionales cuentan con un reconocimiento y prestigio a nivel nacional e internacional, y en algunos casos, hasta por pensionados.

Esta práctica podría estar indicando que, desde temprana formación, los estudiantes están ganando un espacio en el mercado laboral, relacionado con la organización de la información, las búsquedas, y la recuperación y gestión de servicios en forma independiente.

Lugar de trabajo

A pesar de que el sector escolar es el que tiene mayor cantidad de profesionales, las bibliotecas especializadas, públicas y universitarias constituyen uno de los espacios en los que se desenvuelven los estudiantes de la carrera en su etapa de formación y 
durante la práctica profesional y el desarrollo de proyectos como parte de la labor de extensión que se brinda desde la escuela.

Cabe aclarar que en el sector educativo, durante muchos años y en la actualidad en pocos casos, las funciones bibliotecarias eran desempeñadas por los educadores debido a la falta de formación profesional en el área, lo que constituyó una práctica que se ha ido superando con la promoción de nuevos cuadros profesionales, con énfasis en lo pedagógico.

Con respecto a la situación laboral, ésta denota un alto grado de estabilidad laboral en los empleos, debido a que el $56.7 \%$ de los encuestados se encuentran en cargos permanentes.

Tipo de actividades

Es importante destacar que el $73.74 \%$ de los profesionales se desempeñan en actividades que implican gestión administrativa, ya sea en unidades de información especializadas o en proyectos específicos.

Esta situación viene a indicar la imagen que tienen los empleadores sobre los puestos claves que desempeñan los profesionales en las instituciones que tienen a cargo, específicamente los relacionados con las actividades y funciones de dirección y administración.

La actividad relacionada con la docencia está representada con un porcentaje muy bajo. Esto se debe a que la mayor parte de los académicos imparten la docencia como su segunda actividad profesional, ya que invierten la mayor cantidad de horas laborales en otras funciones propias de su puesto.

\section{Grado de dificultad para conseguir empleo}

Casi la mitad de los encuestados opinaron que hay menos dificultades de acceso laboral que en otras profesiones. Esta situación puede estar relacionada con la inserción temprana en el mercado laboral que tienen los estudiantes en su etapa de formación. Esta 
práctica hace que el empleador se relacione tempranamente con el quehacer del bibliotecólogo y se cree una imagen positiva de la profesión y su desempeño; no obstante, significa una mayor responsabilidad y supervisión por parte del docente, quien debe garantizar el nivel profesional del trabajo que realicen los estudiantes. También la garantía de obtener un titulo profesional con dos años y medio de formación facilita la inserción temprana en el mercado laboral.

Aun cuando es considerable el porcentaje de egresados que opinaron que tienen algunas dificultades para insertarse en el mercado laboral, esta opinión puede deberse a varios motivos que podrían considerarse en futuros estudios, como el reconocimiento salarial, el nivel profesional requerido para el puesto y la mayor competencia por los puestos de trabajo, que ocurre en los últimos años debido a la mayor cantidad de ofertas académicas.

\section{PERCEPCIÓN DE LA PROFESIÓN}

Con respecto a la percepción de la carrera de bibliotecología se obtuvieron los siguientes resultados.

Características de los graduados

Los resultados muestran una alta tendencia a la capacidad de trabajo en equipo como la característica más buscada por los empleadores, seguida de la creatividad y la innovación, así como el manejo de las tecnologías.

Esta situación podría estar relacionada con la tendencia al trabajo interdisciplinario en las empresas de servicios, donde el bibliotecólogo debe interactuar con otros especialistas en el desarrollo de proyectos y propuestas de gestión.

No obstante, a pesar de que el $81 \%$ manifiesta sentirse satisfecho con las características de los profesionales, un $19 \%$ considera la necesidad de que el profesional cuente con el dominio 
de una segunda lengua como parte de las competencias que se deben generar en su proceso de formación.

Grado de formación

La evaluación sobre el grado de formación de los graduados es positiva, por encima de un 70\%, y los rubros mejor evaluados son: la capacidad para el uso de las tecnologías y la resolución de problemas. Los otros aspectos merecen una valoración entre un $71 \%$ y un $77 \%$ (capacidad para la toma de decisiones, iniciativa, adaptación a nuevas situaciones, expresión oral y escrita y capacidad para trabajar en equipo).

Lo anterior concuerda también con la opinión externa en relación con las fortalezas que predominan en la formación. En primer lugar, se considera como predominante el manejo de las tecnologías; en segundo lugar, los conocimientos técnicos y, en tercero, la disposición y atención de usuarios con porcentajes similares. Otras características señaladas de manera individual se relacionan con la apertura y la adecuación al cambio, la inventiva, el compromiso con el trabajo, la proactividad, la exigencia consigo mismos, el trato humano y la gestión de servicios.

Como carencias, se señalan el manejo de una segunda lengua, la capacidad de liderazgo e innovación y la creatividad, la investigación y la disposición para participar en proyectos interdisciplinarios. La segunda y tercera carencia se relacionan con los profesionales que se desempeñan en las bibliotecas escolares, aspectos que podrían estar repercutiendo en la imagen que se tiene de la carrera.

\section{Conocimiento de la carrera}

De acuerdo con los resultados obtenidos, es posible determinar que gran parte de los encuestados (55\%) no tienen conocimiento sobre lo que es la bibliotecología. Un 43\%, a su vez, indicó que 
tiene poco conocimiento sobre la carrera, lo que refleja la inadecuada o escasa difusión que se ha hecho al respecto.

Por otra parte, el $97 \%$ de las personas encuestadas expresaron no recibir información sobre esta carrera en sus colegios, y sólo el $2 \%$ respondió afirmativamente. Cuando se le consultó si habían recibido información en otros lugares aparte del colegio, el 21\% respondió que sí, mientras que el 78\% respondió que no.

Estos indicadores refuerzan la necesidad de lograr que los colegios ofrezcan información apropiada sobre la carrera de bibliotecología, con el propósito de incrementar el conocimiento que la población estudiantil tiene de ella. Además, se hace importante una acción conjunta con el personal del Departamento de Orientación con el fin de que el material informativo se dé a conocer, año con año, a los estudiantes para que amplíen, de esta forma, su panorama de opciones a la hora de tomar en cuenta una carrera universitaria.

Temática con la que los estudiantes de secundaria relacionan la carrera

Un alto porcentaje de los estudiantes de secundaria relacionan la carrera de bibliotecología con algunos conceptos preestablecidos: el $89 \%$ la asocia con los libros, el $79 \%$ la vincula con la lectura y el 75\% contestó que con la información.

Cuando se les consultó por otros conceptos que se les venían a la mente cuando pensaban en bibliotecología, algunos de ellos contestaron textualmente: "aburrimiento", "temas de español" y "papeleo y reciclaje". Esto refleja que, por la falta de información que tienen los estudiantes acerca de la carrera, crean en su imaginario conceptos y relaciones opuestos o sin concordancia con lo que se realiza en la carrera de bibliotecología. Todas estas relaciones convergen en la aparición de arquetipos que perjudican la imagen de esta profesión. 


\section{Valoración de la carrera}

Se pudo constatar que las opiniones sobre la importancia atribuida a la bibliotecología en la sociedad por parte de la población joven de secundaria, se encuentran divididas del siguiente modo: poco importante (28\%), muy importante (27\%), mientras que el $25 \%$ la estima como importante. En cuanto al resto de los encuestados, el 14\% opinó que no era importante y el $6 \%$ no respondió.

En definitiva, si no existe información sobre la carrera es difícil que el estudiante emita una valoración real acerca de lo que es la bibliotecología, pues si, en un supuesto, se hubiese preguntado sobre la importancia de una carrera como medicina, sería más fácil para el estudiante valorarla ya que ésta se encuentra mejor posicionada socialmente, y a pesar de que no se conocen todas sus especialidades se tiene una idea clara de las funciones que realizan sus graduados.

Definitivamente la valoración va a influir en la imagen y en el concepto que se tenga de la carrera. Al respecto, el 100\% de los docentes estuvo de acuerdo en que existe un gran desconocimiento sobre la profesión, y ese pensamiento se ve influido con lo que muestran las bibliotecas escolares que, como expresan algunos de los encuestados, "lamentablemente están mal manejadas".

Otra de las opiniones sostuvo que en la sociedad se transmiten ideas equivocadas sobre la bibliotecología a través de diferentes medios que influyen en el pensamiento de los jóvenes; textualmente, una persona lo expresó de la siguiente forma: "los ejemplos que tienen los chicos de esta profesión son muy estereotipados (bibliotecas escolares, o ideas que son difundidas por películas u otras instancias)".

El 50\% enfatizó que la carrera no se visualiza como una opción atractiva al compararla con otras carreras que ya tienen un posicionamiento social. Como lo comentó una de ellas: "En Costa Rica, existen profesiones que son consideradas de prestigio y, además, muy rentables económicamente (medicina, derecho, ingenierías, arquitectura, administración de negocios, informática, etcétera);

para los jóvenes, la bibliotecología no se encuentra en este listado”. 
Agendas de Investigación en Bibliotecología...

Por su parte, las autoridades de la Escuela estuvieron de acuerdo en la necesidad de divulgar, adecuadamente, la oferta de la carrera; reconocen, asimismo, que la carrera no se ha proyectado con fuerza, ni se ha puesto énfasis en la importancia de la bibliotecología en la sociedad y el dinamismo que esta profesión posee.

\section{CONSIDERACIONES FINALES}

- El mercado laboral que tienen los bibliotecólogos es muy amplio. La formación interdisciplinaria que recibe el estudiante, así como la práctica e inserción en el desarrollo de proyectos a temprana edad de su formación, contribuye a que éste obtenga una visión más amplia del campo disciplinario y su proyección.

- Es evidente que el sector laboral en el que se desenvuelve la mayoría de los egresados lo constituye el sector público; existe un escaso número de profesionales que se desempeñan en actividades independientes, específicamente en consultorías. Sin embargo, esta práctica se ha incrementado en los últimos años con la aparición de agencias de prestación de servicios.

- Los empleadores opinan que la carrera de bibliotecología debe impartirse y que la inserción de los jóvenes a temprana edad de su formación en el mercado laboral, mediante la practica supervisada, constituye una oportunidad para dar a conocer el ámbito de acción de la disciplina. Consideran que los profesionales son indispensables en las instituciones, ya que contribuyen al mejoramiento de la calidad de la sociedad y le dan valor a la información. La bibliotecología es una carrera necesaria, pero debe invertirse en la formación en una segunda lengua y en aspectos relacionados con la administración y la planificación estratégica. 
- En cuanto a la imagen que la Escuela de Bibliotecología desea proyectar en los jóvenes de secundaria, el 75\% de los entrevistados concuerda con que se debe mostrar la imagen de una carrera que pueda competir con las demás, enfatizando la relevancia de la gestión de la información para el desarrollo económico y social del país. El 25\% opina que la Escuela de Bibliotecología se debe mostrar como "una entidad viva, moderna, una carrera apoyada en las nuevas tecnologías, con mercado laboral activo y especialmente contrario al paradigma que se tiene en muchos círculos profesionales y sociales en general".

- Las autoridades concuerdan con la mayoría de los académicos en cuanto a que la imagen por proyectar debe basarse en las ventajas del estudio de esta profesión. Se debe mostrar como una carrera competitiva, dinámica y moderna.

- Entre los retos que enfrentan quienes laboran en bibliotecología, los formadores de cuadros profesionales y las entidades de servicios y proyección universitaria se encuentran:

- Iniciar un proceso de sensibilización social con diferentes empleadores y, como parte de sus acciones, la divulgación de la carrera y el quehacer del bibliotecólogo; contribuir al fomento de una cultura de información porque sabemos que la disciplina debe incursionar en la parte social, porque damos un servicio y brindarlo significa interactuar con entidades sociales.

- Programas educativos vs programa de formación continua

Además de continuar con una cultura de evaluación curricular, se deben crear capacidades en el profesional para que participe en la formación continua tanto en el campo de las tecnologías como en el campo de la investigación, sin dejar de lado el fomento de competencias bibliotecológicas básicas. En este sentido, los programas de formación continua ayudan a complementar esas nuevas prácticas de trabajo. 


\section{REFERENCIAS BIBLIOGRÁFICAS}

Allendez, P., Nayar, L. (2009), "Mercado de trabajo, capacitación continua y trayectoria laboral de los profesionales de ciencias de la información", Boletín de la Asociación Andaluza de Bibliotecarios, Núm. 94-95, ene.-jun., pp. 85-104.

Oviedo, F (2011), Arquetipos bibliotecarios: diseño de una propuesta didáctica multimedia que contribuya con la mejora de la imagen de la bibliotecología en la sociedad costarricense, Tesis de maestría, Heredia, C.R., Universidad Nacional.

Pineda, J. (2002), "Realidad laboral de los bibliotecarios y bibliotecólogos: egresados de la Escuela de Bibliotecología, dependiente de la Facultad de Filosofía, de la Universidad Nacional de Córdoba, Argentina”, Biblios, Vol. 3, Núm. 012.

Ugalde, A. Barboza, L. (2010), Estudio parcial de percepción de los programas educativos en la comunidad bibliotecológica: opinión de los(as) empleadores(as) de la Escuela de Bibliotecología, Documentación e Información de la Universidad Nacional, Heredia, C.R.

Universidad Nacional (Costa Rica), Escuela de Bibliotecología, Documentación e información (2009), Informe de Acreditación de la Carrera de Bibliotecología y Documentación, Heredia, C.R., UNA.

Universidad Nacional (Costa Rica), Escuela de Bibliotecología, Documentación e información (2008), Informe del Proceso de Autoevaluación de la Carrera de Bibliotecología y Documentación. Empleadores(as), Heredia, C.R., UNA.

Universidad Nacional (Costa Rica), Escuela de Bibliotecología, Documentación e información (2008), Informe del Proceso de Autoevaluación de la Carrera de Bibliotecología y Documentación, Graduados(as), Heredia, C.R., UNA. 


\title{
Profesionales de la documentación en España: ¿qué demandan los mercados?
}

\author{
JUAN CARLOS MARCOS RECIO \\ Universidad Complutense de Madrid, España
}

\section{INTRODUCCIÓN}

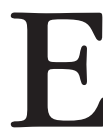
1 mundo laboral experimentó en los últimos años una transformación sin parangón en la historia, por encima incluso de la primera Revolución Industrial. En el siglo xx, un trabajador permanecía toda su vida laboral en la misma empresa. En la actualidad se produce un fenómeno tan cambiante que, en una década, un empleado puede haber variado de compañía en diferentes ocasiones. Y también de área profesional.

Frente a esta situación de cambio, determinar qué demandan los mercados es arriesgado, pues las transformaciones son tan grandes que apenas se pueden contabilizar y, sobre todo, aplicar. Aún así, se propone un estudio tomando como referencia la primera década del siglo XXI, que es la de formación de los bibliotecarios y documentalistas actuales. La propuesta utiliza tres tipos de fuentes con informes anuales y mensuales del mercado de trabajo estatal por colectivos de personas tituladas universitarias ${ }^{1}$ del: a) Servicio Público de Empleo Estatal (SEPE), ${ }^{2}$ dependiente

$1 \mathrm{http} / / / \mathrm{www}$. sepe.es/indiceObservatorio/buscar.do?indice=1\&tipo=2\&period $\mathrm{o}=$ anual\&ambito $=$ Nacional\&tema $=07 \&$ idioma $=\mathrm{es}$

2 Véase en http://www.sepe.es 
del Ministerio de Empleo y Seguridad Social; ${ }^{3}$ b) estudios de campo realizados en la universidad española (aunque existen y son de gran calidad y valor para el estudio de la inserción laboral universitaria, no se han utilizado cifras, datos, documentos o informes de los Observatorios de Empleo de las Universidades Españolas, debido a que el objetivo de este trabajo es dar una visión global y de conjunto, en lugar de ejemplos particulares e influidos por factores como el prestigio de la universidad, la ubicación geográfica, etcétera), y c) los datos de algunas empresas de colocación online, entre ellas la más prestigiosa de España, Infojobs. ${ }^{4}$

Conviene precisar que la implantación del Espacio Europeo de Educación Superior (EEEE) generó una avalancha de este tipo de estudios, pero que una vez implantados apenas han seguido actualizándose.

\section{EVOLUCIÓN DEL MERCADO DE TRABAJO PARA TITULADOS EN BIBLIOTECONOMÍA Y DOCUMENTACIÓN, Y EN DOCUMENTACIÓN}

El informe muestra la formación de los titulados en Biblioteconomía y Documentación (ByD en adelante) y comparados con la Documentación y su formación complementaria en cursos de su especialidad tras acabar sus estudios de diplomatura y/o licenciatura.

Así, el informe anual del Instituto Nacional de Empleo (2003), titulado "Información del mercado de trabajo de las titulaciones universitarias del área de Ciencias Sociales y Jurídicas” del Ministerio de Trabajo y Asuntos Sociales refleja los siguientes datos estadísticos sobre los titulados universitarios en Biblioteconomía y Documentación:

3 Véase en http://www.empleo.gob.es

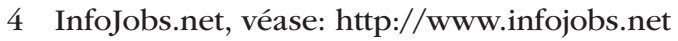


Profesionales de la documentación en España...

Tabla 1

¿En qué ocupaciones se estấn contratando estos titulados?

\begin{tabular}{|l|c|c|}
\hline & $\begin{array}{c}\text { No }^{\circ} \\
\text { Contratos }\end{array}$ & $\begin{array}{c}\text { Personas } \\
\text { contratadas }\end{array}$ \\
\hline Empleado administrativo, en gral. & 644 & 521 \\
\hline Bibliotecario & 342 & 274 \\
\hline Documentalista & 204 & 183 \\
\hline Dependiente de comercio, en gral. & 150 & 134 \\
\hline Ayudantede biblioteca & 128 & 94 \\
\hline Peón de la ind. manufacturera, en gral. & 101 & 80 \\
\hline Camarero, en gral. & 94 & 50 \\
\hline Entrevistador, agente encuestas/censos & 62 & 18 \\
\hline Mozo carga/descarga, almacén & 61 & 45 \\
\hline Peón de la ind. aliment.,bebidas y tabaco & 52 & 16 \\
\hline
\end{tabular}

Biblioteconomía y Documentación, p.17.

¿En qué ocupaciones se están contratando estos titulados?

\begin{tabular}{|l|c|c|}
\hline & $\begin{array}{c}\mathrm{N}^{\circ} \\
\text { Contratos }\end{array}$ & $\begin{array}{c}\text { Personas } \\
\text { contratadas }\end{array}$ \\
\hline Empleado administrativo, en gral. & 138 & 120 \\
\hline Documentalista & 89 & 78 \\
\hline Bibliotecario & 80 & 67 \\
\hline Entrevistador, agente encuestas/censos & 43 & 8 \\
\hline Ayudantede biblioteca & 42 & 32 \\
\hline Dependiente de comercio, en gral. & 21 & 20 \\
\hline Archivero & 20 & 19 \\
\hline Peón de la ind. manufacturera, en gral. & 15 & 15 \\
\hline Formador de formadores & 14 & 13 \\
\hline Empleado adtivo. De biblioteca & 12 & 8 \\
\hline \multicolumn{2}{|c|}{ Documentación, p. 141. } \\
\hline
\end{tabular}

Con respecto a las ocupaciones, a comienzos del siglo XXI, un alto porcentaje de los estudiantes de ByD y Documentación encontraron trabajo en puestos relacionados con su especialidad. Pero, al acabar sus estudios e inscribirse en sus respectivos organismos regionales de empleo, donde se pueden elegir seis profesiones, los de $\mathrm{ByD}$ optaron por Bibliotecario como primera opción, seguida de ayudante de biblioteca y documentalistas en tercer lugar. Por su parte, los documentalistas, se posicionaron por la Documentación, luego la biblioteca y en tercer lugar por ser archiveros.

Tabla 2

\begin{tabular}{|l|c|}
\hline \multicolumn{2}{|l|}{$\begin{array}{l}\text { ¿Qué ocupaciones solicitan para } \\
\text { trabajar? ( }{ }^{*} \text { Ocupación }\end{array}$} \\
\hline Bibliotecario & $\begin{array}{c}\mathrm{N}^{\circ} \text {. } \\
\text { Personas }\end{array}$ \\
\hline Ayudante de biblioteca & 1.313 \\
\hline Documentalista & 1.288 \\
\hline Ayudante de documentalista & 1.159 \\
\hline Ayudante de archivo & 922 \\
\hline
\end{tabular}

(*) Un demandante de empleo puede solicitar hasta un máximo de 6 ocupaciones

Biblioteconomía y Documentación, p. 17.

¿Qué ocupaciones solicitan para trabajar? (*)

\begin{tabular}{|l|c|}
\hline \multicolumn{1}{|c|}{ Ocupación } & $\begin{array}{c}\mathrm{N}^{\circ} \\
\text { Personas }\end{array}$ \\
\hline Documentalista & 480 \\
\hline Bibliotecario & 421 \\
\hline Archivero & 305 \\
\hline Ayudante de biblioteca & 305 \\
\hline Ayudante de documentalista & 227 \\
\hline
\end{tabular}

(*) Un demandante de empleo puede solicitar hasta un máximo de 6 ocupaciones

Documentación, p. 141. 
Es importante destacar que ya en 2003, cuando se elaboró este informe, tanto los titulados en ByD como en Documentación tenían una mayor inserción laboral cuando ampliaban su formación y sus estudios en Diseño de páginas Web, Internet y, en general, en herramientas informáticas. Con los titulados en Documentación, el nivel informático es mucho más destacado y de mayor nivel, e incluye los lenguajes de programación. Por otro lado, el estudio de comunicación e idiomas es mayor en el caso de titulados en ByD, que en Documentación. Es decir que, tras acabar sus estudios, ambos colectivos suman más formación y terminan encontrando trabajo en Diseño de páginas web y en temas relacionados con Internet y el mundo de la tecnología (bases de datos, programas de gestión y aplicación...).

Tabla 3

\section{INSERCIÓN PROFESIONAL $\left({ }^{*}\right)$}

¿Cuál ha sido la inserción profesional de los universitarios en las especialidades con mayor volumen de alumnos formados?

\begin{tabular}{|c|c|c|c|}
\hline Especialidad & $\begin{array}{l}\mathrm{N}^{\circ} \text { Alumnos } \\
\text { formados }\end{array}$ & $\begin{array}{l}\mathrm{N}^{0} \text { Alumnos } \\
\text { contratados }\end{array}$ & \% Inserción \\
\hline Diseño de páginas web & 48 & 33 & $68,75 \%$ \\
\hline Ofimática & 36 & 22 & $61,11 \%$ \\
\hline Iniciación a la red Internet & 28 & 19 & $67,86 \%$ \\
\hline Aplicaciones informáticas de gestión & 23 & 17 & $73,91 \%$ \\
\hline Aplicaciones informáticas de oficinas & 16 & 11 & $68,75 \%$ \\
\hline Ayudante de documentación de medios de comunicación & 15 & 11 & $73,33 \%$ \\
\hline Experto en autopistas de la información, Internet e infovia & 10 & 5 & $50,00 \%$ \\
\hline Inglés: gestion comercial & 8 & 7 & $87,50 \%$ \\
\hline Técnicas de documentación & 8 & 6 & $75,00 \%$ \\
\hline Inglés: atención al público & 7 & 5 & $71,43 \%$ \\
\hline Administrador de sistemas operativos de redes locales & 7 & 5 & $71,43 \%$ \\
\hline Inglés turístico: agencias de viaje & 7 & 6 & $85,71 \%$ \\
\hline Especialista informática educativa & 7 & 5 & $71,43 \%$ \\
\hline Programador aplicaciones informáticas & 6 & 5 & $83,33 \%$ \\
\hline Programador de aplicaciones con bases de datos relacionales & 6 & 3 & $50,00 \%$ \\
\hline
\end{tabular}


Es preciso destacar que la especialización era fruto de planes de Formación Ocupacional, lejos de los itinerarios de los programas universitarios, que se postulaban insuficientes, y por lo tanto, tenían que ser complementados.

Tabla 4

\section{INSERCIÓN PROFESIONAL $(*)$}

¿Cuál ba sido la inserción profesional de los universitarios en las especialidades con mayor volumen de alumnos formados?

\begin{tabular}{|c|c|c|c|}
\hline Especialidad & $\begin{array}{c}\mathrm{N}^{\circ} \text { Alumnos } \\
\text { formados }\end{array}$ & $\begin{array}{l}\mathrm{N}^{\circ} \text { Alumnos } \\
\text { contratados }\end{array}$ & \% Inserción \\
\hline Diseño de páginas web & 14 & 8 & $57,14 \%$ \\
\hline Iniciación a la red Internet & 7 & 5 & $71,43 \%$ \\
\hline Aplicaciones informáticas de gestión & 6 & 3 & $50,00 \%$ \\
\hline Ofimática & 4 & 1 & $25,00 \%$ \\
\hline Ayudante de documentación de medios de comunicación & 4 & 1 & $25,00 \%$ \\
\hline Aplicaciones informáticas de oficinas & 3 & 1 & $33,33 \%$ \\
\hline Inglés turístico: agencias de viaje & 3 & 2 & $66,67 \%$ \\
\hline Secretariado de dirección & 2 & 1 & $50,00 \%$ \\
\hline Inglés: gestión comercial & 2 & 2 & $100,00 \%$ \\
\hline Lenguajes de programación & 2 & 2 & $100,00 \%$ \\
\hline Prog aplic. redes inter intra e & 2 & 2 & $100,00 \%$ \\
\hline Téc. hardware microinformático & 2 & 2 & $100,00 \%$ \\
\hline Analista aplicaciones informat & 2 & 2 & $100,00 \%$ \\
\hline Especialista diseño asistido por ordenador & 2 & 2 & $100,00 \%$ \\
\hline Técnicas de documentación & 2 & 1 & $50,00 \%$ \\
\hline
\end{tabular}

Documentación, p. 145.

El mismo informe muestra otras titulaciones universitarias que compiten por ocupaciones propias de los titulados en ByD y en Documentación. En el caso de la ocupación de Bibliotecario, los profesionales de ByD ocupan el primer lugar, pero los titulados en Documentación estarían en la cuarta plaza. 
Agendas de Investigación en Bibliotecología...

Tabla 5

¿Qué titulaciones universitarias compiten por esta ocupación?

Titulaciones universitarias

Biblioteconomía y documentación (D)

Historia

Geografía e historia

Documentación

Historia del arte

(*) Contratos de demandantes de empleo con titulación universitaria
Contratos $(*)$

$342 \quad 274$

155126

$104 \quad 94$

$80-67$

$76-61$

Bibliotecario, p. 184.

En cuanto al trabajo de Documentalista, sorprendentemente, los titulados en Documentación ocupan el tercer lugar a favor de los titulados en Historia, con el segundo lugar, y los de ByD el primero.

\section{Tabla 6}

\begin{tabular}{|lcc|}
\hline \multirow{2}{*}{ ¿ué titulaciones universitarias compiten por esta ocupación? } \\
Bitulaciones universitarias & Contratos $(*)$ & Personas contratadas \\
Historia & 204 & 183 \\
Documentación & 106 & 93 \\
Historia del arte & 89 & 78 \\
Geografía e historia & 75 & 59 \\
(*) Contratos de demandantes de empleo con titulación universitaria & 73 & 64 \\
\multicolumn{2}{c}{ Documentalista, $p .193$} \\
\hline
\end{tabular}

En la misma línea de este informe citado, estarían algunos de los estudios llevados a cabo en universidades y en organismos profesionales, como la Asociación Española de Documentación e Información (SEDIC). Así, la Universidad Carlos III se ha preocupado por hacer un seguimiento de la respuesta profesional de sus alumnos. En concreto, el profesor Moreiro González ha capitaneado un grupo de investigadores con el fin de conocer el mercado profesional al que han llegado sus alumnos. Ya en 1999, empiezan los estudios sobre estos temas: "Respecto a cómo se distribuyen los asociados de nuestra área, los estudiantes y diplomados en Biblioteconomía y Documentación suponen el 7\% 
del total, mientras que los estudiantes y licenciados en Documentación representan el $6 \%$. Por lo tanto, entre las dos titulaciones suman un $13 \%$ de asociados, de un total compuesto por diecisiete titulaciones" (Moreiro: 1999, 5). Cinco años más tarde, en otro estudio, en tres universidades españolas, Complutense, Alcalá y Carlos III, con el mismo director, se les pregunta a los titulados si han encontrado trabajo en el sector de información y documentación, y el 93,4\% indica que sí, frente a un 5,7\% que señaló que no habían buscado trabajo en ese sector.

Sin embargo, una vez que se han establecido los nuevos planes de estudio en ByD y Documentación, esos trabajos de campo han dejado de hacerse, al menos desde la perspectiva educativa, pero se siguen realizando en el ámbito profesional (ver epígrafe 2).

Los siguientes datos que aquí se muestran se obtuvieron del Informe anual del mercado de trabajo que figura en el Servicio de Empleo Público Estatal de España, titulado: Observatorio de las Ocupaciones (2009), "Titulados Universitarios y Otras enseñanzas AULA 2009"5 y hacen referencia al año 2008. Se trata de un informe mucho menos completo que el de 2003 (el más completo de la última década), pero muestra la situación de los titulados en ByD y en Documentación antes de terminar la década pasada y en el momento inicial de la crisis. En este informe se pueden comparar las expectativas profesionales tanto de Bibliotecarios como de Documentalistas.

Tabla 7

\begin{tabular}{|c|c|c|c|}
\hline Ocupaciones más solicitadas por los demandantes (2) & \begin{tabular}{c|}
$\%$ \\
Demandantes
\end{tabular} & Ocupaciones mas solicitadas por los demandantes (2) & $\begin{array}{c}\% \\
\text { Demandantes }\end{array}$ \\
\hline Biblotecarıs, documentallstas y asımulados & $38,49 \%$ & Bibliotecarios, documentalistas y asimilados & $44,36 \%$ \\
\hline Ayudantes de biblioteca y asimilados & $34.76 \%$ & Ayudantes de biblioteca y asimilados & $33,79 \%$ \\
\hline Empleados de bibliotecas y archivos & $22,98 \%$ & Archiveros y conservadores de museos & $27.62 \%$ \\
\hline Ayudantes de archivo y de museo & $21.15 \%$ & Empleados de bibliotecas y archivos & $22,1 \%$ \\
\hline Archiveros y conservadores de museos & $20,96 \%$ & Ayudantes de archivo y de museo & $21.94 \%$ \\
\hline Taquigratos y mecanógratos & $17,63 \%$ & Taquigrafos y mecanógrafos & $11,93 \%$ \\
\hline $\begin{array}{l}\text { Dependientes y exhibidores en tiendas, almacenes, quioscos y } \\
\text { mercados }\end{array}$ & $3.96 \%$ & Otros diversos protesıonales de la enseñanza & $2,96 \%$ \\
\hline Secretarios administrativos y asimilados & $3,32 \%$ & Profesores de enseñanza secundaria & $2,88 \%$ \\
\hline Otros diversos profesionales de la enseñanza & $2.53 \%$ & Secretanios administrativos y asımulados & $2 \%$ \\
\hline Animadores comunitarios & $2,37 \%$ & $\begin{array}{l}\text { Dependientes y exhibidores en tiendas, almacenes, quioscos y } \\
\text { mercados }\end{array}$ & $1,92 \%$ \\
\hline \multicolumn{2}{|c|}{$\begin{array}{l}\text { (2) Nota: Una persona puede solicitar hasta un máximo de } 6 \text { ocupaciones } \\
\text { Biblioteconomía y Documentación, p. } 34 \text {. }\end{array}$} & \multicolumn{2}{|c|}{$\begin{array}{l}\text { (2) Nota: Una persona puede solicitar hasta un maximo de } 6 \text { ocupaciones } \\
\text { Documentación, p. } 42 .\end{array}$} \\
\hline
\end{tabular}

5 Observatorio de las Ocupaciones, Agosto de 2012. 
Al respecto de las ocupaciones más solicitadas por los estudiantes de $\mathrm{ByD}$, un 38,49\% pidió trabajo como bibliotecario y/o documentalista, y el porcentaje mayor en los estudios de documentación, donde alcanzó un 44,36\%. En las ocupaciones más contratadas, en el primer caso, el de Bibliotecarios, se firmó un $20,24 \%$ de contratos y un $28,86 \%$ para los documentalistas, con lo que ambas ocuparon la primera posición de las ocupaciones.

Tabla 8

\begin{tabular}{|c|c|c|c|c|c|}
\hline Ocupaciones más contratadas & Contratos & Personas & Ocupaciones más contratadas & Contratos & Personas \\
\hline Bibllotecarios, documentallstas y asimulados & $20,24 \%$ & $25,83 \%$ & Bibllotecarlos, documentallstas y asımulados & $28,86 \%$ & $34,41 \%$ \\
\hline Taquigratos y mecanógratos & $7,58 \%$ & $9,68 \%$ & Taquigrafos y mecanógrafos & $7,67 \%$ & $8.57 \%$ \\
\hline Ayudantes de biblioteca y asimilados & $7,58 \%$ & $8,25 \%$ & Ayudantes de biblioteca y asimilados & $7,14 \%$ & $8,43 \%$ \\
\hline Empleados de bibliotecas y archivos & $6,08 \%$ & $7,33 \%$ & Empleados de bibliotecas y archivos & $5,86 \%$ & $6,46 \%$ \\
\hline $\begin{array}{l}\text { Auxiliares administrativos con tareas de atención al público no } \\
\text { clasificados anteriormente }\end{array}$ & $5,07 \%$ & $6,19 \%$ & $\begin{array}{l}\text { Auxiliares administrativos con tareas de atención al público no } \\
\text { clasificados anteriormente }\end{array}$ & $5,01 \%$ & $5,48 \%$ \\
\hline $\begin{array}{l}\text { Dependientes y exhibidores en tiendas, almacenes, quioscos y } \\
\text { mercados }\end{array}$ & $4,7 \%$ & $5,33 \%$ & Archiveros y conservadores de museos & $3.51 \%$ & $4.21 \%$ \\
\hline $\begin{array}{l}\text { Auxiliares administrativos sin tareas de atención al público no } \\
\text { clasificados anteriormente }\end{array}$ & $3,28 \%$ & $4,52 \%$ & $\begin{array}{l}\text { Auxillares administratvos sin tareas de atención al púb\|lico no } \\
\text { clasificados anteriormente }\end{array}$ & $3,41 \%$ & $4,35 \%$ \\
\hline Secretarios administrativos y asimilados & $2,8 \%$ & $3,78 \%$ & Secretarios administrativos y asimilados & $2,98 \%$ & $3,79 \%$ \\
\hline Archiveros y conservadores de museos & $2,68 \%$ & $3.49 \%$ & Otros diversos profesionales de la enseñanza & $2.45 \%$ & $2.95 \%$ \\
\hline Otros diversos profesionales de la ensefíanza & $1.99 \%$ & $2.23 \%$ & $\begin{array}{l}\text { Dependientes y exhibidores en tiendas, almacenes, quioscos y } \\
\text { mercados }\end{array}$ & $2,34 \%$ & $2,67 \%$ \\
\hline
\end{tabular}

Atendiendo al último Informe mensual del mercado de trabajo de personas tituladas, referido al mes de agosto de $2012^{6}$ en cuanto a la titulación de $\mathrm{ByD}$, se explica que "los contratos indefinidos son los que más han crecido en el último año, un 25\% con respecto al mismo mes del año anterior". En cuanto a la titulación de Documentación, "los contratos temporales son los que más han crecido en el último año, un $22,45 \%$ con respecto al mismo mes del año anterior".

6 http://www.sepe.es/contenido/observatorio/titulaciones/2012_08/titulados/ ciencias_sociales_y_juridicas/ESTUDIO_TITULADOS_FI_6.pdf 
Gráfica 1

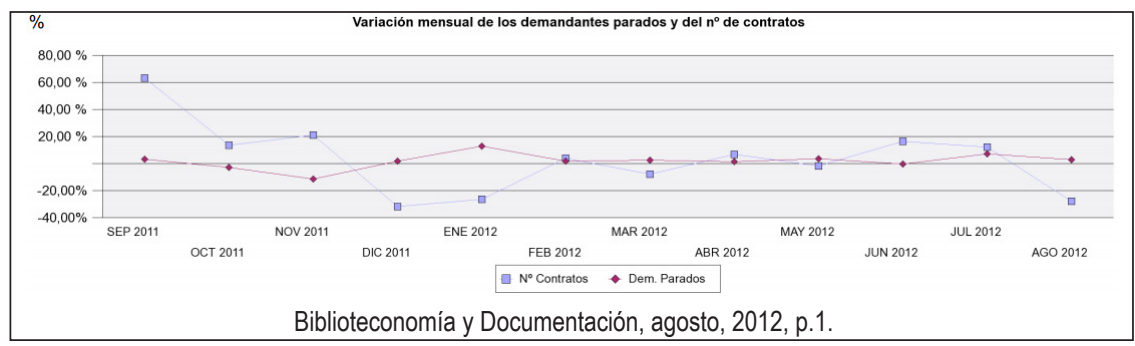

\section{Gráfica 2}

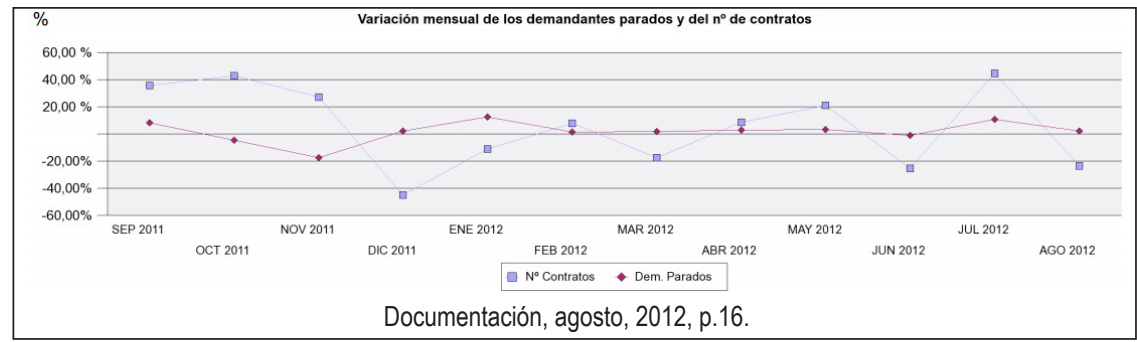

Por último, hay un descenso considerable en ByD, ya que sólo se hicieron 11 contratos en dicha especialidad, lo que supuso un $7,43 \%$, mientras que en documentación hubo valores más positivos, pues destacan 8 contratos en la administración pública y 6 en bibliotecas y/o archivos.

Tabla 9

\begin{tabular}{|c|c|c|c|c|c|c|c|}
\hline \multicolumn{4}{|c|}{ OCUPACIONES MÁS CONTRATADAS } & \multicolumn{4}{|c|}{ OCUPACIONES MÁS CONTRATADAS } \\
\hline & $\begin{array}{c}\text { Total } \\
\text { Contratos }\end{array}$ & $\begin{array}{l}\% \\
\text { s/t }\end{array}$ & $\begin{array}{c}\begin{array}{c}\% \text { variación } \\
\text { anual(") }\end{array} \\
\text { and }\end{array}$ & & $\begin{array}{c}\text { Total } \\
\text { Contratos }\end{array}$ & $\begin{array}{l}\% \\
\mathbf{s} / \mathrm{t}\end{array}$ & $\begin{array}{l}\text { \% variación } \\
\text { anual(") }\end{array}$ \\
\hline - Bibliotecarios, documentalistas y afines & 11 & $7,43 \%$ & $-66,67 \%$ & - Archivistas y conservadores de museos & 2 & $3,23 \%$ & $100,00 \%$ \\
\hline - Empleados de bibliotecas y archivos & 5 & $3,38 \%$ & $25,00 \%$ & - Bibliotecarios, documentalistas y afines & 5 & $8,06 \%$ & $-66,67 \%$ \\
\hline $\begin{array}{l}\text { - Empleados de servicios de correos (excepto } \\
\text { empleados de mostrador) }\end{array}$ & 12 & $8,11 \%$ & $\% 500,00 \%$ & $\begin{array}{l}\text { - Empleados de oficina de servicios de apoyo a la } \\
\text { próducción }\end{array}$ & 2 & $3,23 \%$ & \\
\hline $\begin{array}{l}\text { - Empleadós àdmininistrativós sin tảreás de atención al } \\
\text { público no clasificados bajo otros epígrafes }\end{array}$ & 8 & $5,41 \%$ & $-27,27 \%$ & - Empleados de bibliotecas y archivos & 6 & $9,68 \%$ & $500,00 \%$ \\
\hline $\begin{array}{l}\text { - Empleados administrativos con tareas de atención al } \\
\text { público no clasificados bajo otros epígrafes }\end{array}$ & 14 & $9,46 \%$ & $600,00 \%$ & $\begin{array}{l}\text { - Empleados de servicios de correos (excepto } \\
\text { empleados de mostrador) }\end{array}$ & 5 & $8,06 \%$ & \\
\hline - Camareros asalariados & 7 & $4,73 \%$ & $75,00 \%$ & $\begin{array}{l}\text { - Empleados administrativos sin tareas de atención al } \\
\text { público no clasificados bajo otros epigrafes }\end{array}$ & 8 & $12,90 \%$ & $166,67 \%$ \\
\hline - Vendedores en tiendas y almacenes & 7 & $4,73 \%$ & $0,00 \%$ & - Téleoperadores & 2 & $3,23 \%$ & $-33,33 \%$ \\
\hline $\begin{array}{l}\text { - Personal de limpieza de oficinas, hoteles y otros } \\
\text { establecimientos similares } \\
\text { - Peones agricolas (excepto en huertas, }\end{array}$ & 7 & $4,73 \%$ & $16,67 \%$ & $\begin{array}{l}\text { - Empleados administrativos con tareas de atención al } \\
\text { público no clasificados bajo otros epigrafes }\end{array}$ & 2 & $3,23 \%$ & $0,00 \%$ \\
\hline $\begin{array}{l}\text {-Peones agricolas (excepto en huertas, } \\
\text { invernaderos, viveros y jardines) }\end{array}$ & 6 & $4,05 \%$ & $200,00 \%$ & - Vendedores en tiendas y almacenes & 3 & $4,84 \%$ & $50,00 \%$ \\
\hline $\begin{array}{l}\text { - Peones del transporte de mercancías y } \\
\text { descargadores }\end{array}$ & 5 & $3,38 \%$ & $\% 400,00 \%$ & $\begin{array}{l}\text { - Peones agrícolas (excepto en huertas, } \\
\text { invernaderos, viveros y jardines) }\end{array}$ & 5 & $8,06 \%$ & \\
\hline \multicolumn{8}{|c|}{$\begin{array}{l}\left({ }^{*}\right) \text { Los } \% \text { de variación se calculan: los mensuales sobre el mes anterior; } \\
\text { los anuales sobre el mismo mes del año anterior }\end{array}$} \\
\hline \multicolumn{4}{|c|}{ Biblioteconomía y Documentación, agosto, 2012, p. 1.} & \multicolumn{4}{|c|}{ Documentación, agosto, 2012, p. 16.} \\
\hline
\end{tabular}


Estos informes del Servicio de Empleo Público Estatal muestran datos de toda la década, sobre las titulaciones de ByD y sobre Documentación. Además, otras titulaciones con las que se podrían contrastar y cruzar datos para conocer el "intrusionismo" en la profesión y generar series de datos muy precisas con evoluciones mensuales, conocer y realizar estudios sobre estacionalidad, tipos de contratos, estabilidad... Es preciso indicar que una parte importante de los estudiantes de las dos especialidades apuestan por trabajar para el Estado en algunas de sus muchas variantes, pero este dato está separado del cargo ocupado en una biblioteca pública, que puede ser también una institución del Estado.

\section{DATOS DE INFOJOBS.NET: LA REALIDAD ONLINE}

Conocida la situación en el ámbito universitario y estatal, conviene precisar ahora lo que el sector profesional está realizando. Para ello, se toma como punto de partida Infojobs.net, ${ }^{7}$ una de las Web de empleo líder en España. Creada en 1998, sirve una media de 180.000 .000 páginas vistas al mes según datos de OJD del último año. "Según la empresa líder en investigación en análisis de Internet, Nielsen NetRatings, InfoJobs es la bolsa de empleo privada núm. 1 en Europa, e incluso supera a la homóloga del INEM en Alemania. InfoJobs es la bolsa de empleo online líder en el mercado español, tanto por el tráfico de su web site como por el volumen de empresas y candidatos usuarios". ${ }^{8}$ Su fundación y sede está en Barcelona y se encuentra enclavada dentro del Grupo Intercom. ${ }^{9}$ En la actualidad, cuenta con aproximadamente 200 trabajadores, siendo su accionista mayoritario el grupo noruego de clasificados Schibsted. ${ }^{10}$

7 InfoJobs.net, véase: http://www.infojobs.net

8 Véase en: http://comunicacion.infojobs.net/corp/index.jsp?MQ\%3D\%3D\&Q WNOdWFsaWRhZA\%3D\%3D

9 Véase en http://www.grupointercom.com/

10 Véase en http://www.schibsted.no 
Para este estudio se elije esta plataforma porque en marzo de 2012, Infojobs.net ofrece la herramienta Plan de Carrera, aun en versión BETA, basada en tecnología analítica de InnoQuant Strategic Analytics; es decir, que los datos que aporta se fundamentan en realidad en las experiencias de sus usuarios.

InfoJobs pretende ser "un servicio de información que ayuda a tomar decisiones relacionadas con el desarrollo profesional de los usuarios, mostrándoles las trayectorias que han seguido otros profesionales. [...] Con este servicio queremos compartir el conocimiento que hemos acumulado durante más de 10 años, fruto de nuestra actividad como portal líder de empleo", ${ }^{11}$ dicen en su web.

No es lo único que ofrecen, ya que junto a la Escuela de Negocio ESADE" 12 elaboran el "Informe InfoJobs ESADE sobre el mercado laboral en España"13, tomado como referente en muchas de las empresas españolas y sobre todo en los departamentos de Recursos Humanos a la hora de contratar.

\section{Diplomado en ByD y Licenciado en Documentación}

Basándonos en los datos de la Herramienta de Plan de Carrera de Infojobs.net, se puede conocer la realidad laboral de los Titulados en la Diplomatura de Biblioteconomía y Documentación ${ }^{14}$ y los de la Licenciatura en Documentación. ${ }^{15}$ Se estudian, ahí, la trayectoria formativa, la información sobre el empleo y las estadísticas de ambos.

11 Véase en http://plandecarrera.infojobs.net/que-es-plan-de-carrera

12 Véase en http://www.esade.edu

13 Véase en http://www.infojobs.net/empresas/mercado-laboral-infografia

$14 \mathrm{http}: / /$ plandecarrera.infojobs.net/formacion/biblioteconomia-y-documentacion_77

15 http://plandecarrera.infojobs.net/formacion/documentacion 


\section{Información sobre trayectoria formativa}

Esta sección muestra la trayectoria formativa de los estudiantes de ByD y en Documentación, y nos indica en qué otros centros han estudiado posteriormente, donde la tendencia es clara y la transferencia entre ambas titulaciones es la más representativa. Es importante ver las titulaciones en Comunicación y Publicidad, Humanidades e Informática, que son las disciplinas estudiadas tras acabar estudios de ByD y Documentación.

\section{Gráfica 3}

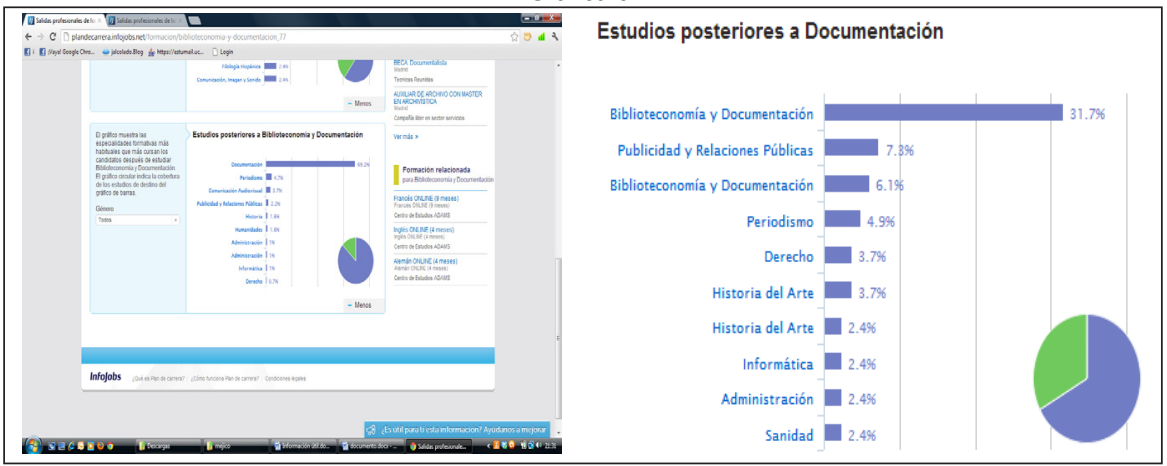

Información sobre empleo

En este apartado se precisa la situación laboral de los estudiantes de ByD y Documentación por sectores industriales, su nivel de mando y las empresas y organizaciones que las contratan.

De los candidatos registrados en Infojobs 271 (26,06\%) de los titulados en ByD están trabajando, así como el 39,96\% de los de Documentación (185). 
Profesionales de la documentación en España...

Gráfica 4

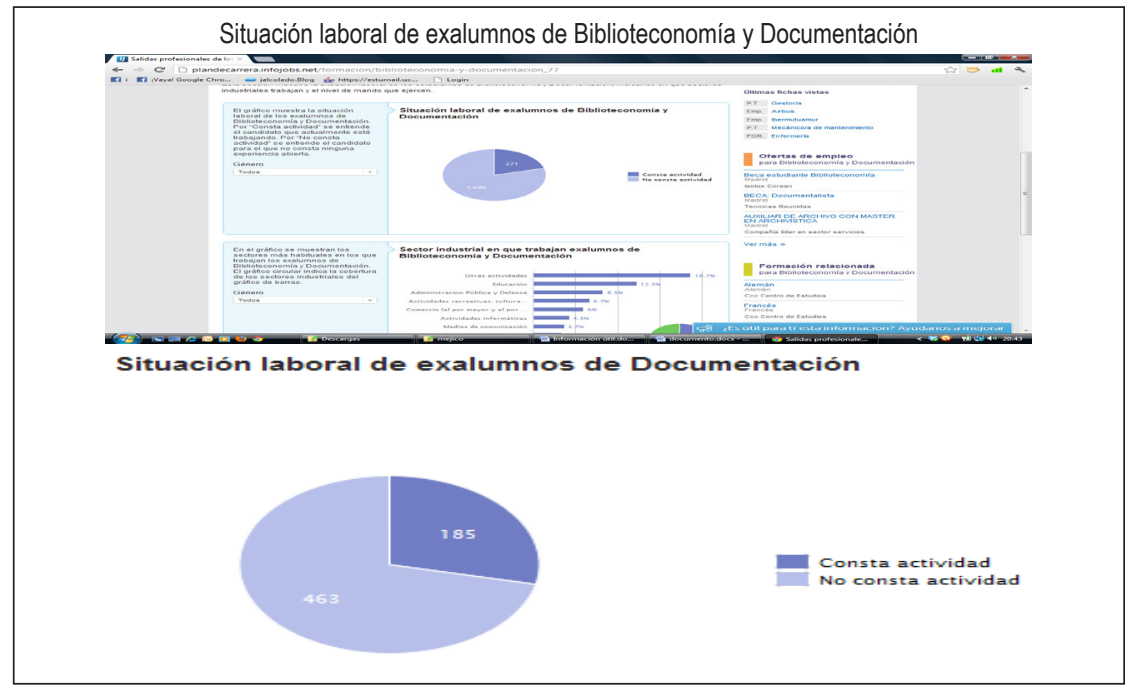

Con respecto al sector industrial, alumnos de ByD optan por la Educación (12,3\%), por delante de las administraciones públicas $(8,3 \%)$ y las actividades recreativas y culturales. En Documentación eligen los mismos sectores pero el porcentaje es algo mayor (17,6\% y 10,3\%). En ambos casos, casi un $20 \%$ de ellos está en otras actividades, no relacionadas con ByD y Documentación.

Gráfica 6

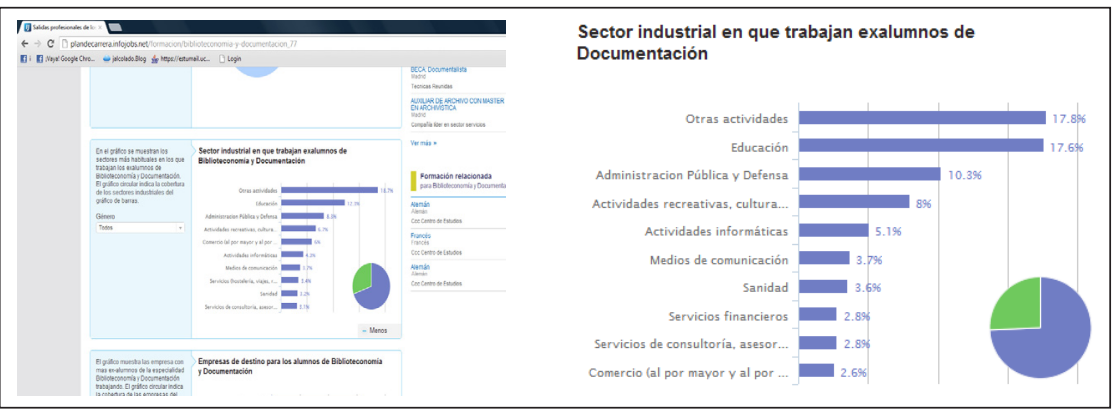


Agendas de Investigación en Bibliotecología...

Por su parte, algunas de las empresas donde terminan trabajando estos alumnos de ByD apenas tienen relación con la especialidad, pero en Documentación sí la tienen, fundamentalmente en las universidades.

Gráfica 7

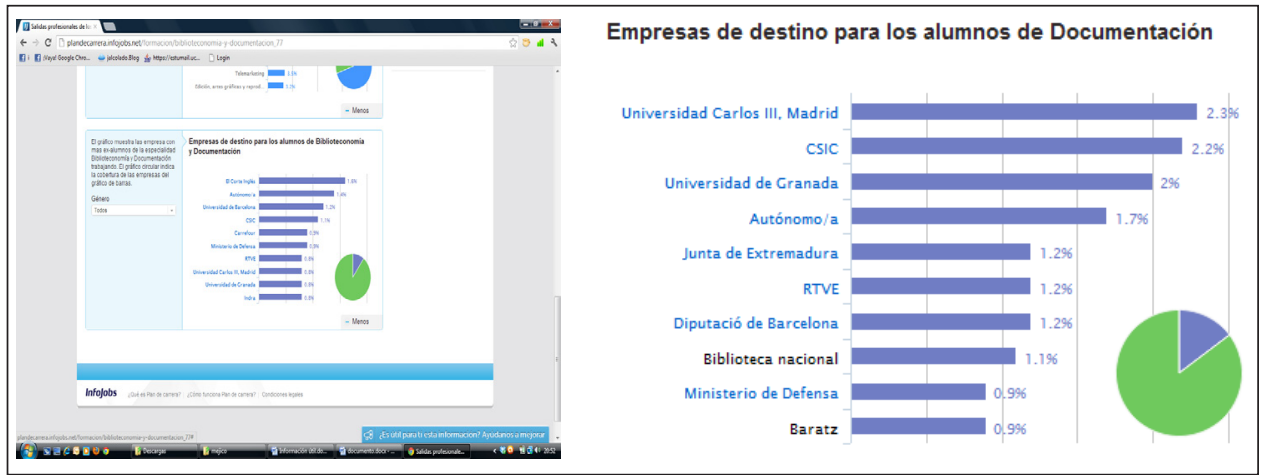

Información estadística de la especialidad de estudios

También es importante conocer las universidades donde se forman los profesionales de la ByD y los de Documentación. Como se muestra en el siguiente gráfico, la UCM es la más popular en ByD y la de Granada en la especialidad de documentación.

Gráfica 8

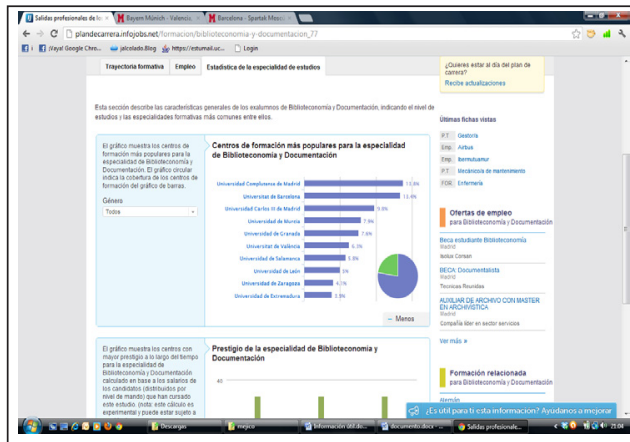

Centros de formación más populares para la especialidad de Documentación

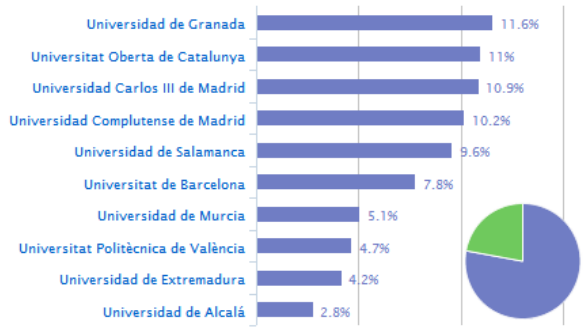


Comparativa entre el empleo de Bibliotecario y Documentalista

Para los Diplomados de ByD, el empleo más común es el de Bibliotecario ${ }^{16}$ y para el Licenciado en Documentación, el de Documentalista. ${ }^{17}$ Pues bien, esto es lo que vamos a comparar a través de los datos de la Herramienta de Plan de Carrera de Infojobs.net.

\section{Educación}

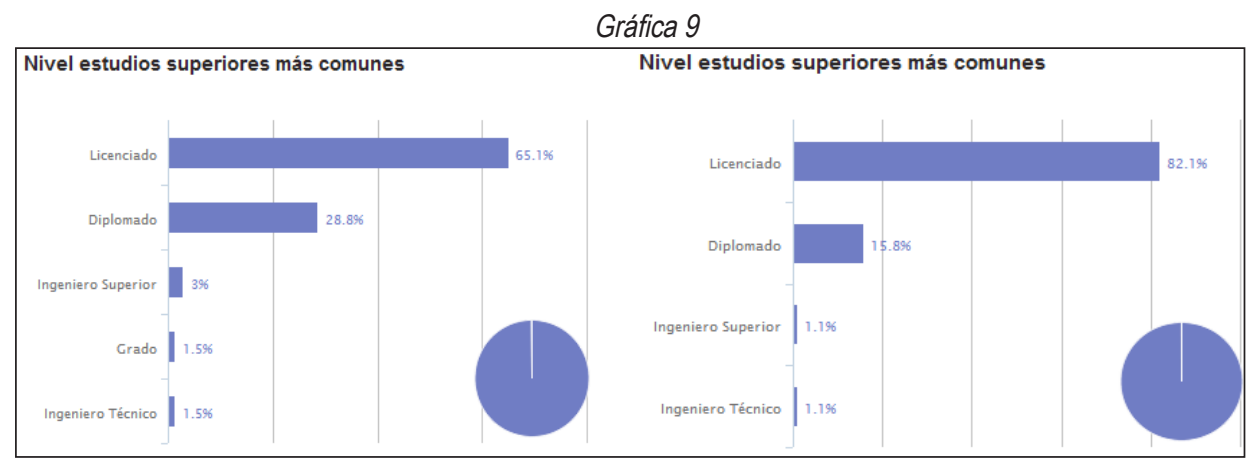

Procede ahora presentar la formación más habitual de los profesionales que han trabajado de Bibliotecario y de Documentalista. En la Gráfica 9 se muestra el nivel de estudios máximo alcanzado por personas que actualmente trabajan como Bibliotecario (izquierda) y como Documentalista (derecha). Conviene precisar que casi el doble de los diplomados ha accedido a la profesión de Bibliotecario, de los que lo han hecho como Documentalista. Esta última profesión se postula casi para licenciados, mucho más especializada, con un $82,1 \%$.

Conviene también señalar (Gráfica 10) las especialidades estudiadas por los que trabajan como Bibliotecarios (izquierda) y Documentalistas (derecha). Obviamente, las especialidades formativas más habituales de los candidatos que actualmente tra-

$16 \mathrm{http}: / /$ plandecarrera.infojobs.net/puesto-de-trabajo/bibliotecario

17 http://plandecarrera.infojobs.net/puesto-de-trabajo/documentalista 
Agendas de Investigación en Bibliotecología...

bajan como Bibliotecario y Documentalista son las propias de la carrera estudiada para cada caso. Pero es preciso hacer notar el alto grado de "intrusionismo", sobre todo con los titulados en Historia, quienes ocupan el segundo lugar para el puesto de Documentalista, por encima de los titulados en Biblioteconomía y Documentación; y, el tercer lugar, para el puesto de Bibliotecario. Si además se sumaran los titulados de Historia con los de Historial del Arte, dos ramas de la misma carrera, la proporción de "intrusionismo" de esta especialidad sería mucho más significativa.

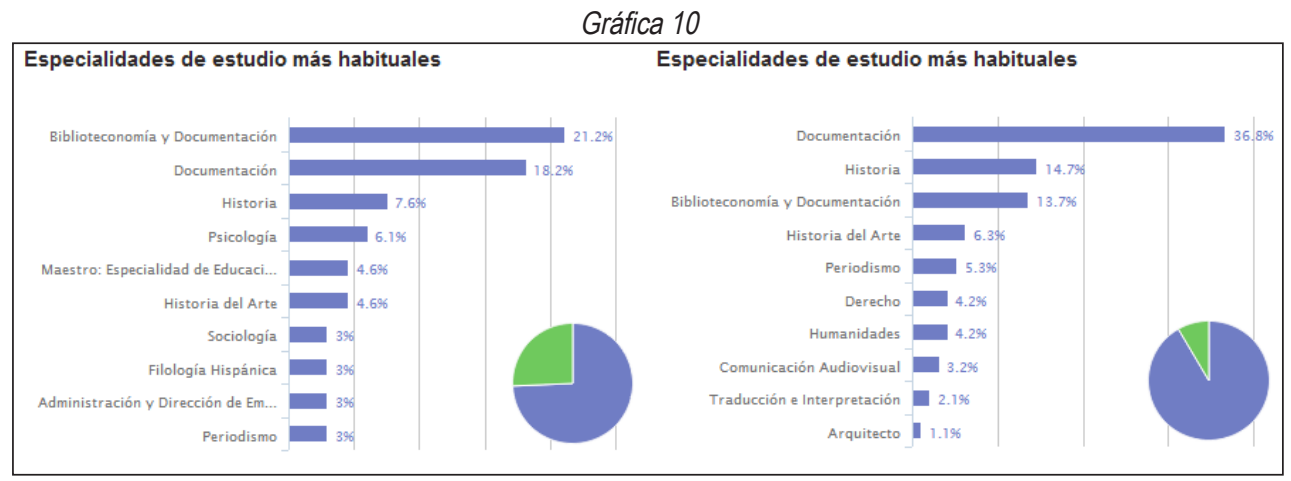

Trayectoria profesional

En cuanto a la trayectoria profesional, las dos gráficas (11 y 12) son bastante representativas y muestran la similitud que existe entre ambas profesiones, así como su interrelación.

\section{Gráfica 11}

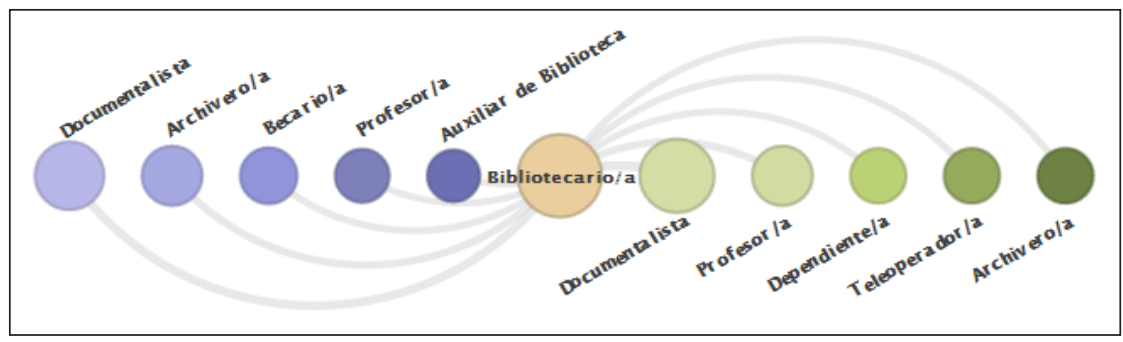


En el centro se puede ver el puesto de Bibliotecario y/o Documentalista, según el caso. A la izquierda de cada gráfica, se observan los puestos anteriores; y a la derecha, los puestos de trabajo posteriores a los que accedieron.

Gráfica 12

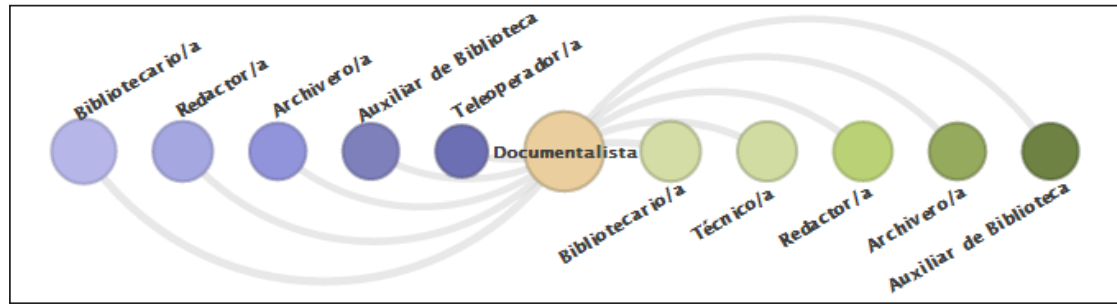

Este estudio, si bien refleja una realidad actual, no siempre puede considerarse que un bibliotecario y/o un documentalista van a trabajar en esas dos especialidades. Como se indicó al principio del trabajo, los cambios en el mundo laboral son muy rápidos; además, en tales profesiones, los estudiantes de esas especialidades se han visto obligados a realizar otras profesiones, muchas de ellas sin que tengan nada que ver con su preparación, como podrían ser la de teleoperador y/o monitor. Así, se muestran ahora los trabajos más habituales desempeñados por los profesionales antes de llegar a ser Bibliotecario y Documentalista (Gráfica 13). Hay que señalar que, en el caso de los documentalistas, el campo de acción es mayor ya que han trabajado además como bibliotecarios, pero también como redactores, archiveros y auxiliares de bibliotecas, y luego ya en una serie de trabajos no relacionados directamente con su carrera. En cuanto a los alumnos de ByD se comprueba fácilmente que siendo bibliotecarios, antes han sido documentalistas y archiveros. 
Agendas de Investigación en Bibliotecología...

Gráfica 13

\begin{tabular}{|r|r|r|}
\hline Puestos de trabajo anteriores más habituales & Puestos de trabajo anteriores más habituales \\
\hline Documentalista & Bibliotecario/a \\
Archivero/a \\
Becario/a \\
Profesor/a
\end{tabular}

Por último (Gráfica 14), se muestran los puestos de trabajo más habituales que han desempeñado los candidatos después de haber trabajado como Bibliotecario (izquierda) y Documentalista (derecha). En el caso de los bibliotecarios, la transformación ha sido hacia documentalistas, con un 13\%, y hacia profesor, un $5,19 \%$. A partir de estos dos rubros, la disparidad de trabajos es grande y no tienen ninguna relación con la especialidad, excepto archivero y auxiliar de biblioteca.

\section{Gráfica 14}

\begin{tabular}{|r|r|r|r|r|}
\hline Puestos de trabajo posteriores más habituales & Puestos de trabajo posteriores más habituales \\
\hline Documentalista \\
Profesor/a \\
Teleoperador/a \\
Dependiente/a \\
Archivero/a
\end{tabular}

Por su parte, los documentalistas se han convertido en bibliotecarios, con un 7,8\%, y técnicos, un 7,5\%, seguido de redactores y archiveros. En este caso, la relación es algo más directa con su anterior puesto de trabajo, pues se incluyen periodista y profesor. 


\section{Estadísticas de los puestos}

Por último, se hizo un seguimiento estadístico con las características generales del puesto de Bibliotecario y de Documentalista, así como con el comportamiento habitual del mercado. En ese seguimiento se observó, evidentemente, un descenso considerable desde el segundo trimestre de 2011 debido a la crisis, pero la tendencia es desigual durante 2009 hasta el momento citado, donde se puede ver que el mercado es más o menos estable y la salud del puesto de trabajo es sostenible. Lo cierto es que no estamos ante puestos de trabajo con altísima demanda en los últimos años, quizás debido a la crisis.

Con respecto a las pirámides de población de los candidatos a Bibliotecario o Documentalista, conviene resaltar que la demanda es menor en hombres que en mujeres, y que según crece la edad los candidatos son menos. Pero esto tiene una clara explicación y es el acceso y los conocimientos de las TIC, ya que conviene recordar que Infojobs.net es un portal en línea.

Además, los datos de seguimiento de esta empresa vuelven a constatar los datos facilitados hace casi una década por el equipo del profesor Moreiro González, ya que el trabajo de Bibliotecario está más ligado a la Administración Pública, que el de Documentalista, que encuentra más acogida entre grandes corporaciones y mass media, entre los que destaca Indra como empresa tecnológica, gran consultora y de servicios externos. En cuanto al trabajo de Documentalista, no hay que despreciar un porcentaje de autónomos, aunque en vez de contabilizarlo como emprendedor o empresario, que los hay, habrá que ligarlos a la función de trabajador adscrito a un proyecto como subcontratado, en vez de como trabajador por cuenta ajena.

\section{OTRAS PROPUESTAS EMPRESARIALES}

No es InfoJobs la única empresa que hace este tipo de estudios, aunque en el ámbito de ByD y de documentación es quien aporta 
los mejores datos. Otras, como Randstad, ${ }^{18}$ elaboran cada año un rango tomando como punto de partida: "Las tendencias del mercado de trabajo, de los sectores económicos que se encuentran en pleno auge y los datos que proporcionan las universidades sobre el número de matriculaciones por titulación".

Randstad es una de las compañías que elaboran su propio estudio sobre las titulaciones más demandadas. En 2010, teniendo en cuenta el entorno de crisis económico, elaboró su propio rango con los diez tipos de profesionales más fáciles de colocar en el mercado laboral. Y en ese rango no figuraban ni ByD ni documentación. Entre los profesionales más demandados por el mercado, y de esta forma se responde al enunciado de este trabajo, figuran las carreras de Administración y Dirección de Empresas, Económicas y Empresariales, porque se pueden reubicar fácilmente en cualquier tipo de negocios y, en consecuencia, encontrar con más facilidad trabajo. Lo mismo se puede decir, según este informe, de los profesionales de la informática y de las telecomunicaciones, con bastantes posibilidades de encontrar empleo. Por último, una serie de estudios también se encuentran en un nivel alto de colocación, a saber: Medicina, Química, Derecho e Ingeniería de Caminos, que aunque son profesiones dispares, disponen de medios para facilitar a los estudiantes un encuentro con el mundo laboral.

En dicho informe se precisan algunas de las características que llevan a un alumno a estudiar una y no otra disciplina: "A la hora de elegir una carrera universitaria, la mayoría elige por pura vocación. De hecho, un $67,96 \%$ de universitarios afirma que volvería a estudiar lo mismo si pudiera elegir (sobre una muestra de 1.094 personas consultadas por Randstad). No es una mala opción si tenemos en cuenta que más del $24 \%$ de la oferta de empleo actual exige algún tipo de titulación universitaria, ya sea una diplomatura, licenciatura, ingeniería o postgrado. Un nivel de cualificación alto es un factor determinante para acceder a un empleo y puede ayudar al candidato a diferenciarse en un momento de escasez de 
oferta de empleo como el actual. En resumen, estudiar una carrera universitaria es una puerta hacia el empleo, ya que las empresas eligen a profesionales cada vez más y mejor formados". En este sentido, los estudiantes de ByD y los de documentación deberían buscar un nivel de cualificación alto en sus estudios y buscar la institución educativa que se los ofrezca, con el fin de tener mayores posibilidades de encontrar trabajo.

Desde el punto de vista práctico, otra empresa muy relacionada con la universidad, Universia, ofrece información a los alumnos sobre el análisis de la situación del mercado laboral y sus resultados, válidos durante un ciclo económico. Aunque hay titulaciones como Medicina, Derecho e Ingenierías que siempre tienen demanda, no sucede así con la especialidad en ByD y en Documentación. Además, Universia pone a disposición del alumno que lo desee, consultar los perfiles profesionales más demandados y una relación de los mismos a través de la herramienta "Universia Emplea" (http://emplea.universia.es) donde diariamente se publican ofertas de prácticas y primer empleo.

Existen otras empresas que hacen estudios similares, pero las aquí citadas son las más utilizadas por las empresas españolas a la hora de tomar una decisión sobre un puesto de trabajo y, en consecuencia, las mejor valoradas por quienes desean encontrar trabajo.

\section{CONCLUSIONES}

Las especialidades de ByD y la de Documentación no figuran entre las más demandadas por los alumnos y, en consecuencia, no es fácil encontrar trabajo una vez finalizados los estudios. Según diversas empresas que gestionan los perfiles profesionales, ambas disciplinas no figuran como las mejores posicionadas para ponerse a trabajar luego de terminarlos. Entre las más solicitadas figuran Administración y Dirección de Empresas y Económicas y Empresariales. 
El problema que se plantea es que la Documentación, y un poco menos la Biblioteconomía, son ciencias jóvenes que aún no han logrado centrarse en un nicho de mercado. Los propios estudios ofrecen parte de otras disciplinas y por eso el intrusionismo profesional es mayor en esta área. Habría entonces que crear y reforzar programas de estudio que atiendan las peticiones del mercado laboral, porque en la actualidad se encuentran un tanto alejadas del mismo.

Los alumnos de ByD y Documentación intercambian sus puestos de trabajo en diferentes especialidades, entre ellas las propias de la titulación, pero también entre otras, como las administraciones públicas, los medios de comunicación e incluso la educación. Conviene señalar que una parte de sus trabajos llega con los planes de Formación Ocupacional al acabar su vida universitaria, porque ahí encuentran trabajo como diseñadores y gestores de contenidos de páginas web, internet, aplicaciones informáticas y de gestión. La respuesta a los mercados, para mejorar la colocación de los profesionales de la documentación, pasa por una adaptación de los planes de estudio a esas realidades del mercado para poder ocupar nuevos nichos de mercado, aplicando tecnologías y trabajo con páginas web.

Internet y el Mundo 2.0, con la explosión de las Redes Sociales, donde la información y su control son un valor económico-comercial en alza, ha traído nuevas profesiones en las que los titulados en ByD y Documentación, por su formación y sus capacidades, son los más adecuados para desempeñarlas. Entre las profesiones 2.0 destacan: el gestor de archivos y bibliotecas digitales, los gestores y creadores de contenidos, los Community Manager (Gestores de la Comunidad), los responsables SEO/SEM, analistas de usabilidad Web, los Técnicos de contenidos 3D y animados como Trafficket, Blogger, los Arquitectos de Información, los Diseñadores de Arte Digital, el Administrador de Bases de Datos, el Gestor de Portales e-commerce, el publicista en línea... $\mathrm{Y}$ todo ello, sin contar las nuevas profesiones surgidas de la tecnología móvil. 


\section{REFERENCIAS BIBLIOGRÁFICAS}

Hernández Armenteros, J. Dir. (2010), “La Universidad española en cifras 2010", Conferencia de Rectores de las Universidades Españolas (CRUE), Jaén, http://www.crue.org/Publicaciones/UEC.html

Instituto Nacional de Empleo (2003), Información del mercado de trabajo de las titulaciones universitarias del área de Ciencias Sociales y Jurídicas, Ministerio de Trabajo y Asuntos Sociales. http:// www.sepe.es/indiceObservatorio/buscar.do?indice $=1 \&$ tipo $=2 \&$ pe riodo $=$ anual $\&$ ambito $=$ Nacional $\&$ tema $=07 \&$ idioma $=e s$

Moreiro González, J. A. (1999), "Ajuste de los licenciados en documentación a la oferta de trabajo. Observaciones hechas en la Universidad Carlos III de Madrid", Revista General de Información y Documentación, Vol. 9, Núm. 2, pp. 13-28.

Moreiro González, J. A., Azcárate-Aguilar-Amat, P., Marzal-GarcíaQuismondo, M. A., Tejada Artigas, C. M. y Vergueiro, W. (2008), "Desarrollo profesional y opinión sobre la formación recibida de los titulados universitarios en información y documentación de las universidades públicas de Madrid (2000-2005)", El Profesional de la Información, Vol. 17, Núm. 3, pp. 261-272.

Observatorio de las Ocupaciones (2009), Titulados Universitarios y Otras enseñanzas AULA 2009, Servicio Público de Empleo, http:// www.sepe.es/indiceObservatorio/buscar.do?indice=1\&tipo=2\&pe riodo $=$ anual $\&$ ambito $=$ Nacional $\&$ tema $=07 \&$ idioma $=e s$

Observatorio de las Ocupaciones (agosto de 2012), Información Mensual de Mercado de Trabajo de Titulados Universitarios, Servicio Público de Empleo Estatal, http://www.sepe.es/contenido/ observatorio/titulaciones/2012_08/titulados/ciencias_sociales_y_ juridicas/ESTUDIO_TITULADOS_FI_6.pdf 
Agendas de Investigación en Bibliotecología...

Observatorio de las Ocupaciones (2012), Los perfiles de la Oferta de Empleo. Servicio Público de Empleo Estatal, http://www.sepe.es/ contenido/observatorio/pdf/Perfiles_oferta_empleo.pdf

Randstad, Las carreras con más salidas profesionales (2010), http:// www.randstad.es/content/aboutrandstad/sala-de-prensa/notasde-prensa/2010/carreras-mas-demandadas.xml

Universia. Proyección Laboral de las Titulaciones, http://pre.universia.es/que-estudiar/proyeccion-laboral-carreras/ (disponible en video). 


\title{
El depósito legal en la protección de los bienes documentales: estado actual y cambios deseables
}

\author{
JUAN ESCOBEDO ROMERO \\ y MARTín ÁNGEl CERvantes ACOSTA \\ Universidad Autónoma de San Luis Potosí, México
}

\section{EL DEPÓSITO LEGAL EN EL MUNDO}

Tr os profesionales de las Ciencias de la Información conocen y saben la importancia que tiene el depósito legal; éste es una actividad que se ha instituido en muchos países desarrollados de Europa y de América del Norte, los cuales han llevado esta disposición a niveles que son dignos de reproducir en los países en vías de desarrollo. Esta práctica sigue un proceso lógico y secuencial que consiste en, al menos, cinco etapas principales. La primera acción del depósito legal es recopilar la producción documental de un país, a la cual le sigue un proceso que elabora un reporte de todo lo recopilado; más tarde, se generan padrones de productores y, luego, estadísticas de la producción; el último paso es constituir y desarrollar las colecciones de la producción nacional, local, o regional de los países. El depósito legal tiene una trayectoria a lo largo de la historia o un similar histórico que ha sido la base para el desarrollo de grandes colecciones, al menos desde el siglo XVIII. Con el riesgo de hacer una generalización, podemos asumir que muchos de los países del mundo tienen esta disposición para construir sus patrimonios culturales y su memoria cultural. 


\section{El DEPÓSITO LEGAL EN MÉXICO}

El país es uno de tantos que tienen esta disposición vigente, aunque no en efectivo funcionamiento; a pesar de ello, es mejor contar con las disposiciones y trabajar para que éstas se lleven a la práctica. Los postulados de esta disposición legal en su diseño y redacción son interesantes, importantes y fundamentales, porque plantean un escenario sobre el desarrollo ideal de las fuentes de información de un país o, mejor dicho, de la gran mayoría de países que tienen esta práctica institucionalizada y regida por algún tipo de legislación. Lo anterior tiene implicaciones educativas, académicas y culturales de gran repercusión en el desarrollo de los países.

En México, se han expedido mandatos desde 1812 hasta $1991 ;{ }^{1}$ el periodo anterior señala el inicio de las disposiciones en el asunto que nos ocupa en este trabajo, esto claramente tiene un enfoque nacional, mientras que al interior del país las disposiciones legales en la materia en varios casos son posteriores, como sucede en el Estado de San Luis Potosí o en la del Estado de México. ${ }^{2}$ Es importante señalar que existen algunas otras disposiciones legales que se pueden relacionar y vincular para hacer efectivo el Depósito Legal en el país y sus estados, entre ellas aquellas publicadas para la protección del patrimonio cultural, el patrimonio documental, o sobre el libro.

1 Algunos de los aspectos sobre los antecedentes nacionales del Depósito Legal fueron tomados de la página oficial del la Cámara de Diputados:

http://www.diputados.gob.mx/bibliot/apotec/decretos.htm

2 Ley del Depósito Legal para el Estado de México [en línea], 2011, Estado de México: H. Congreso del Estado de México, http://www.edomex.gob.mx/legistelfon/doc/pdf/ley/vig/leyvig174.pdf 
En México el Depósito Legal es gestionado por la Biblioteca Nacional $^{3}$ y por la Biblioteca del Congreso de la Unión; ${ }^{4}$ esta institución declara en su página web los mandatos legales que identifican el concepto sobre lo que significa esta disposición, los cuales coinciden con el objetivo, que consiste en obtener toda clase de documentos y materiales bibliográficos, impresos y en otros formatos, que hayan sido editados y producidos en el país para, con ello, acrecentar el Patrimonio Cultural de la Nación y ponerlo a disposición de los mexicanos.

La disposición sobre el Depósito Legal, soportada por la actividad de la mayoría de las unidades de información del resto del país que se concentran en promover formal o informalmente este mandato, conforman parte de la estructura y condiciones que permiten o pueden permitir que el Depósito Legal sea efectivo y cumpla con su naturaleza, función y objetivo.

A pesar de que se cuenta con la ley, y de que el país tiene una infraestructura que puede facilitar esta actividad, es conocido por muchos especialistas de la disciplina bibliotecológica y de aquellas otras que se relacionan con la producción de fuentes documentales, que las instituciones encargadas de hacer efectivo este mandato legal enfrentan problemas para su correcta ejecución. Un aspecto principal es el que señala Robert Endean Gamboa, ${ }^{5}$ quien dice que las dos bibliotecas que tienen asignada la responsabilidad de hacer cumplir la ley no pueden hacerlo y son incapaces de concretar el acopio de, idealmente, todos los materiales impresos del país. Palabras más, palabras menos, este bibliotecó-

3 El texto completo de la disposición legal sobre esta actividad lo presenta la Biblioteca Nacional en su página web:

http://bnm.unam.mx/index.php/antecedentes-historicos/59

4 La biblioteca se puede consultar en sus aspectos generales en la página web, la dirección del recurso es:

http://biblioteca.diputados.gob.mx/janium-bin/busqueda_rapida. pl?Id=20130223171949

5 Robert Endean Gamboa, "El descontrol bibliográfico de la Biblioteca Nacional de México", Sociedad de la información, (17): 1, octubre 2009. 
logo señala la serie de problemáticas que enfrenta la Biblioteca Nacional en su funcionamiento interno y hacia el exterior, y nos da elementos argumentales y explicativos de por qué esa institución no puede cumplir con la misión legal determinada por el Depósito Legal. En ese sentido coincidimos que el Depósito Legal en la nación y en los estados se encuentra en una situación que debe ser mejorada mediante acciones focalizadas.

\section{ANTECEDENTES Del Depósito LEgAL EN SAN LUIS POTOSÍ}

El personaje más importante de la bibliografía potosina durante el siglo xx es sin duda el licenciado Rafael Montejano y Aguiñaga, cuya pasión por conservar y difundir la producción bibliográfica de San Luis Potosí comienza a materializarse a partir de incorporarse, como parte del personal de la Universidad, a la Biblioteca Pública Universitaria, junto con el licenciado Salvador Penilla López, ambos promotores de la publicación Fichas de Bibliografía Potosina en 1949, publicación bimestral que tenía como propósito ser un índice del movimiento bibliográfico de San Luis y un órgano de la Biblioteca, que permitiera dar a conocer el presente y pasado cultural potosino, así como fomentar en el público el afán de la lectura y atraerlo a su recinto. ${ }^{6}$

Fichas de Bibliografía Potosina hizo posible que se proyectara la primera exposición de Bibliografía Potosina, ${ }^{7}$ con documentos recuperados de la colección de la Biblioteca Pública Universitaria y de las colecciones personales de distintos personajes potosinos allegados a la historia y la literatura. Posteriormente, se desarrollan exposiciones bibliográficas de Jurisprudencia y Medicina, en las que una parte de los documentos expuestos eran también propiedad de la Biblioteca. Estas exposiciones permitirán al licenciado Montejano y al licenciado Penilla la creación de la

6 Presentación, Fichas de Bibliografía Potosina, 1(1): 1, Jul.-Ago., 1949.

7 Decíamos ayer, Fichas de Bibliografía Potosina, 2 (6): 2, Nov.-Dic., 1952. 
Colección de Bibliografía Potosina, llevando a práctica la idea de conservar todo lo publicado en el estado de San Luis Potosí y lo que se hable de éste, intención que se fue extendiendo rápidamente al grado de que la mayor adquisición de fuentes de esta temática fue atendida a través de la donación voluntaria por parte de amigos y personas que creyeron y fortalecieron el proyecto desprendiéndose de sus colecciones para depositarlas desinteresadamente en esa colección que atesoraría la Biblioteca Pública Universitaria.

Es el caso del señor Cirilo Estrada, señorita Ana Gómez del Campo, señor Gabriel Echenique, don Nereo Rodríguez Barragán, señor Diódoro Ruiz, doctor Fernando Quijano Pitman, señor Alejandro Espinosa Pitman, doctor Alberto Alcocer Andalón, licenciado Francisco Pedraza Montes, señor Augusto Eichelmann, presbítero José de Jesús Benítez, monseñor Joaquín Antonio Peñalosa, señor Manuel Rivera del Campo, licenciado Lucia Delgado Oviedo, licenciado Abel Esquivel Avalos, licenciado Inocencio Loyola, doctor Ayax Juan Ochoa, señor Jesús Hermosillo, licenciado Luis López Palau, señor Eliseo Tristán Cervantes, señor Carlos Morán de la Rosa, licenciado Ricardo García López, señor Rodolfo Rico Ríos, señor Jeremías Ariceaga Dávila, licenciado Arnoldo Kaisser S., entre muchos más, que con sus donaciones permitieron, y otros siguen contribuyendo, a la formación de esta colección tan importante para las investigaciones históricas, sociales, culturales, económicas, etcétera, del Estado de San Luis Potosí.

La ambición de consolidar también una colección regional que fortaleciera a la potosina, hizo que uno de sus fundadores -a través de las relaciones que obtuvo por conducto de sus cargos y por sus reconocidas obras escritas- estableciera nexos para intercambiar con El Colegio de Michoacán, El Colegio de México, la Universidad Nacional Autónoma de México, etcétera, obras que fortalecieran el desarrollo de estas colecciones.

La adquisición, bajo la forma de compra, aunque mínima, también ha sido importante; de este modo, valiosas joyas documentales y hemerográficas se han incorporado a los acervos de Bibliografía Potosina. Cabe señalar que, desde el año de fun- 
dación de la Colección, no se le destinó a ésta un presupuesto propio que permitiera adquirir las obras para cumplir con su objetivo, por lo que al principio se confió ésta a personas y asociaciones generosas y a la propia Universidad a través de sus donaciones económicas, con las cuales se logró conservar en territorio potosino todos los manuscritos del poeta Manuel José Othón y, de igual forma, se obtuvo el capital suficiente para comprar la colección completa del periódico El Estandarte. ${ }^{8}$

Como puede observarse, la disposición y voluntad de quienes participaron y participan en el desarrollo de la Colección de Bibliografía Potosina son personas e instituciones preocupadas por heredar a las futuras generaciones los registros necesarios donde sustenten su pasado, pero que, al mismo tiempo, sientan un compromiso con el amigo, el bibliotecario, el sacerdote, el licenciado y el historiador Rafael Montejano y Aguiñaga, a quien no abandonarían en su loable labor de conservar el patrimonio documental potosino.

Los conocimientos bibliotecarios del licenciado Rafael Montejano y su experiencia, que le habían dejado ya cincuenta y un años al frente de la Colección, le permitieron tener la visión para heredarnos antes de su muerte una nueva modalidad de adquisición tal vez presentía que su partida estaba próxima y que, al faltar, aquella misión que había echado a cuestas junto con el licenciado Salvador Penilla, podría quedar desamparada.

Para ese efecto, se vio favorecido por las estrechas relaciones que tenía con Manuel Rivera del Campo, entonces diputado de la LV Legislatura del H. Congreso del Estado de San Luis Potosí, junto con quien preparó una Iniciativa de Decreto para establecer la figura del Depósito Legal, que dejaba como depositaria a la Biblioteca Pública Universitaria, iniciativa titulada Decreto que establece el Depósito Legal para la preservación del Patrimonio Cultural del Estado de San Luis Potosí, que presentó el diputado al H. Congreso del Estado el día 7 de agosto de 2000 para su

8 Rafael Montejano y Aguiñaga, "Reinauguración de la biblioteca pública de la Universidad Autónoma de San Luis Potosí", en Fichas de Bibliografía Potosina,4(2/3): 65 -70, Abril - Septiembre 1957. 
aprobación en el Período Ordinario de Sesiones que se celebraría a fines del mismo mes y año.

Para el día 10 de agosto, el diputado Manuel Rivera le había enviado ya al ingeniero Jaime Valle Méndez, rector de la Universidad Autónoma de San Luis Potosí, copia de la Iniciativa del Decreto y, al mismo tiempo, se solicitaba su apoyo para que el H. Congreso del Estado de San Luis Potosí lo aprobara.9 Ante esta solicitud, el día 24 de agosto el rector envío una carta a la Comisión Permanente del H. Congreso del Estado manifestando su interés y lo grato que resultaba llevar a cabo esta encomienda que debería ser acordada por el $\mathrm{H}$. Consejo Directivo Universitario; sin embargo, en ella manifestaba, también, la preocupación por todos los costos que representaría en infraestructura para la Universidad la aprobación de la Iniciativa de Decreto. ${ }^{10}$

Esta Iniciativa de Ley se turnó para su estudio y dictamen a la Comisión de Gobernación y Puntos Constitucionales y a la Comisión de Cultura, Recreación y Deporte, siendo presidentes el diputado Pablo Valladares García y el diputado Jorge Luis Ramírez Martínez, respectivamente. En su estudio y análisis rendido ante los diputados secretarios del Congreso del Estado el día 25 de agosto de 2000, se expuso que la iniciativa cumplía con los requisitos que marca el Reglamento Interior del Congreso del Estado, que existía la necesidad de establecer la figura del depósito legal, y que el depositario legal sea la Universidad Autónoma de San Luis Potosí, pero que la Iniciativa no encuadraba en la modalidad de Decreto, por lo que se enmarcó como Iniciativa de Ley; por último, se determinó que el nombre que llevaría la iniciativa sería Ley que establece el Depósito Legal para la Preservación del Patrimonio Bibliográfico y Documental del Estado de San Luis Potosí, dictaminando su aprobación el día 31 de agosto y siendo ésta promulgada el 20 de septiembre.

9 Manuel Rivera del Campo [solicitud de apoyo para aprobación de iniciativa de Decreto] [correspondencia]. San Luis Potosí. 2000.

10 Jaime Valle Méndez [consideraciones enviadas a la Comisión Permanente del H. Congreso del Estado, correspondencia], San Luis Potosí, 2000. 
La ley fue publicada en la segunda sección de la edición ordinaria 119 del Periódico Oficial, el 4 de Octubre de 2000. El día 6 de octubre el licenciado Jaime Rasillo Puente, director del Periódico Oficial del Estado entregó varios ejemplares del Decreto 575, relativo a la Ley del Depósito Legal al ingeniero Jaime Valle Méndez, rector de la Universidad. ${ }^{11}$

La empresa emprendida por el entonces diputado Manuel Rivera del Campo y el licenciado Rafael Montejano y Aguiñaga estaba terminada, pero al mismo tiempo este último debería comenzar, con la aplicación de la ley, otra tarea laboriosa que sortear; desafortunadamente cuarenta y seis días no le fueron suficientes para ver cristalizada la adquisición bibliográfica y documental por esta modalidad, el Depósito Legal.

Para septiembre de 2005 el rector de la Universidad de San Luis Potosí emprendió las obras para remodelar las instalaciones de la Biblioteca Pública Universitaria con el objeto de que la Colección de Bibliografía Potosina tuviera la infraestructura necesaria para ejercer el Depósito Legal. Las obras de remodelación fueron concluidas en el año de 2008 y, en el mes de agosto del mismo año, fue reinaugurado el recinto con el nombre de Centro de Documentación Histórica "Lic. Rafael Montejano y Aguiñaga".

A partir de la muerte del licenciado Rafael Montejano y Aguiñaga, tenemos que reconocer que la labor de seguir enriqueciendo la bibliografía potosina fue afectada notablemente debido a que gran parte de la adquisición de la bibliografía potosina estuvo sustentada en el capital social que poseía el licenciado Montejano, gracias al cual un gran número de amigos circunscritos a distintas esferas, como la historia, la política, la educación, la literatura, la religión, etcétera, donaban, sin interés alguno, cada una de sus publicaciones.

Por otra parte, aunque dejó herencia la publicación del Decreto 575 , cierto es que las condiciones de los espacios físicos, de la

11 Jaime Rasillo Puente [envío del decreto al Ing. Jaime Valle Méndez, correspondencia]. San Luis Potosí. 2000. 
estantería, del personal y del presupuesto que tenía la Biblioteca Pública Universitaria, no permitían que se comenzara formalmente con la encomienda de tal disposición legal.

Con el Centro de Documentación Histórica "Lic. Rafael Montejano y Aguiñaga", en funciones a partir del año 2008, queda indefinido el responsable de tan importante función, que aunque en la práctica la ejerce el Centro, en la disposición se otorga a la Biblioteca Pública Universitaria.

\section{AGENDA DE INVESTIGACIÓN}

Como resultado de las reflexiones anteriores nos encontramos ante una situación que nos demuestra un conjunto de perspectivas para la investigación y para la producción de utilidades derivadas de esas investigaciones. Para acotar, en cualquiera de las necesidades que requiere compensar el Depósito Legal, es necesario que se realice un trabajo sistematizado, interdisciplinario e interinstitucional. Con la conjunción de esos tres elementos, es probable que se puedan alcanzar resultados utilitarios para que el Depósito Legal a nivel nacional y en los estados pueda tener lo que en el papel legal se dispone. Consideramos necesario realizar los siguientes procesos para alcanzar el ordenamiento que debería existir. El primero de ellos es:

La reforma a la ley en su Artículo $3^{\circ}$

Porque en este artículo se define a la institución o entidad depositaria, el trabajo que aquí se requiere consiste en un análisis de la situación actual y en la aceptación de las responsabilidades que conlleva ser la entidad encargada del Depósito Legal. 
La elaboración de un padrón de autores, editores y productores

El trabajo o proceso necesario en esta actividad consiste en que la entidad depositaria legal, junto con algún grupo interdisciplinario, se enfoque en la elaboración de un padrón que sirva de herramienta para los procesos de la gestión de las fuentes de información, de las fuentes bibliográficas y documentales en cualquier formato; esto, para el pleno cumplimiento de lo dispuesto en el Articulo $2^{\circ}$ de la Ley sobre el Depósito Legal en San Luis.

El análisis de la producción bibliográfica del estado

Aquí, consideramos que la actividad debe especificarse por la tipología documental. En este caso, hemos privilegiado el formato impreso para que ese sea el sujeto de un primer análisis de las fuentes de información producidas en el estado. Dejamos a otros especialistas el resto de la gama de formatos, los cuales pueden ser estudiados de la misma manera.

\section{REFERENCIAS BIBLIOGRÁFICAS}

Biblioteca Nacional de México. UNAM, disponible en: http://bnm. unam.mx/index.php/antecedentes-historicos/59

Decíamos ayer, Fichas de Bibliografía Potosina, 2(6): 2, nov.-dic., 1952.

Endean Gamboa, Robert, "El descontrol bibliográfico de la Biblioteca Nacional de México", Sociedad de la información, (17): 1, oct., 2009. 
H. Congreso de la Unión, Cámara de diputados, Dirección General del Centro de Documentación, Información y Análisis, disponible en: http://www.diputados.gob.mx/bibliot/apotec/decretos.htm

Ley que establece el Depósito Legal para la Preservación del Patrimonio Bibliográfico y Documental del Estado de San Luis Potosí [en línea]. 2000. San Luis Potosí, México: H. Congreso del Estado de San Luis Potosí. http://148.235.65.21/LIX/documentos/ leyes/68_Ly_Preserv_Bibliografico_Doc.pdf

Ley del Depósito Legal para el Estado de México [en línea]. 2011, Estado de México: H. Congreso del Estado de México. http://www. edomex.gob.mx/legistelfon/doc/pdf/ley/vig/leyvig174.pdf

Montejano y Aguiñaga, Rafael, "Reinauguración de la biblioteca pública de la Universidad Autónoma de San Luis Potosí", Fichas de Bibliografía Potosina, 4(2/3): 65 -70, abr.-sep., 1957.

Presentación, Fichas de Bibliografía Potosina, 1(1): 1, jul.-ago. 1949.

Rasillo Puente, Jaime [envío del decreto al Ing. Jaime Valle Méndez], correspondencia], San Luis Potosí. 2000.

Rivera del Campo, Manuel [solicitud de apoyo para aprobación de iniciativa de Decreto, correspondencia], San Luis Potosí, 2000.

Valle Méndez, Jaime [consideraciones enviadas a la Comisión Permanente del H. Congreso del Estad, correspondencia], San Luis Potosí. 2000. 


\section{Desarrollo e impacto de las bibliotecas públicas en México y Colombia}

FEDERICO HeRnández PACHECO

Universidad Nacional Autónoma de México

\section{INTRODUCCIÓN}

T a biblioteca pública se ha desarrollado en América Latina conforme a las diferentes situaciones geográficas, económicas, sociales, culturales y políticas que históricamente se han manifestado en los países de la región y que conforman un rico caleidoscopio de modelos y formas de operación, los cuales esperan ser investigados.

En la última década, las bibliotecas públicas latinoamericanas han sido noticia por el reconocimiento que han merecido por parte de organismos internacionales. De esta manera, y luego de una valoración de sus proyectos y funcionamiento, han recibido reconocimiento y apoyo financiero las bibliotecas públicas de Chile, Colombia, Guatemala y México, entre otras naciones.

Los desarrollos alcanzados por México y Colombia han sido objeto de estudio y comentarios en encuentros nacionales e internacionales, donde se tratan asuntos sobre la esencia de la biblioteca pública, sus fortalezas y debilidades, las tecnologías de vanguardia, la lectura, sus retos y modalidades, la diversidad de servicios, los nuevos paradigmas para la gestión de los recursos 
humanos y los distintos modelos de biblioteca sobre los que se tienen evidencias.

Las bibliotecas públicas en México y Colombia presentan distinciones que hemos señalado en otro momento. ${ }^{1}$ No obstante, también encontramos paralelismos que nos permiten preguntarnos sobre cómo el desarrollo de las bibliotecas públicas impacta en sus sociedades. Con estas ideas nos abocamos a realizar un estudio exploratorio para conocer el impacto de las bibliotecas públicas en ambos países, de manera que notemos los componentes que puedan servir como puntos de partida para futuras investigaciones.

\section{MARCO CONCEPTUAL}

El impacto de las bibliotecas públicas en la sociedad ha sido un tema tratado por varios autores, ${ }^{2}$ quienes han considerado que los servicios bibliotecarios juegan un rol importante para aliviar problemas y como soporte para la construcción, la consolidación y el mantenimiento del tejido social.

Catherine Johnson dice que la biblioteca como espacio público sirve a la gente de distintas clases, etnias, religiones y cultura, para interactuar de formas heterogéneas en una total democracia. De esta manera, en las bibliotecas públicas se debe enfatizar y hacer prevalecer la tolerancia y el entendimiento. ${ }^{3}$

En este contexto el impacto puede definirse de diversas formas por el efecto que tiene un servicio o producto bibliotecario

1 F. Hernández Pacheco, Estudio comparativo de las bibliotecas públicas de México y Colombia, México: Universidad Nacional Autónoma de México, Instituto de Investigaciones Bibliotecológicas y de la Información, 2013 [en prensa].

2 Suaiden, 2002; Nelson y Mc Clure Fraser, 2003; Aabo, 2005; Abad Fernández, 2006.

3 Catherine A. Johnson (2010), "Do public libraries contribute to social capital? A preliminary investigation in to the relationship", Library \& Information Science Research, 32, p. 148. 
en la comunidad, y por los cambios que éstos producen en las actitudes o comportamientos de las personas o los grupos. Al respecto, cabe resaltar que cuando estudiamos el impacto debemos tomar en consideración que puede ser benéfico o perjudicial; es decir, positivo o negativo.

Aquí nos interesa conocer los cambios benéficos y positivos que provocan las bibliotecas públicas en las comunidades donde están enclavadas. Por ello, entendemos que los resultados a nivel de propósito o fin de un programa deben implicar un mejoramiento significativo en esas comunidades y en las personas, que en algunos casos debe ser perdurable o sustentable en el tiempo. ${ }^{4}$

Ponjuán define el impacto como un indicador utilizado en la bibliotecología para relacionar el uso de la información y las bibliotecas, con los resultados alcanzados en la práctica social y su influencia en los cambios ulteriores. Así, al medir el impacto, es posible mostrar el resultado de las actividades en la práctica social, lo cual permite a su vez mostrar el valor e importancia de las bibliotecas y la información. En otras palabras, medir el impacto supone la existencia de cambios en el bienestar de los individuos. ${ }^{5}$

Por su parte, Greenhalgh, Landry y Worpole identifican cinco áreas de política pública o esferas de influencia en las que impactan las bibliotecas públicas y donde prevalece muy poca investigación; estas áreas son las siguientes:

- Educación.

- Políticas sociales.

- Información.

- Cultura.

- Desarrollo económico. ${ }^{6}$

4 B. E. Liberta Bonilla (2007), "Impacto, impacto social y evaluación del impacto”, ACIMED, 15(3), 29 sept., 2012, en: http://scielo.sld.cu/pdf/aci/v15n3/ aci08307.pdf

5 Cf. G. Ponjuán Dante (1998), Gestión de información en las organizaciones. Principios, conceptos y aplicaciones, Santiago: CECAPI, p.65.

6 L. Greenhalgh, Landry, C., Worpole, C. (1993), Borrowed time? The future of public libraries in the UK, Bournes Green: Comedia. 
Pero también están la interacción y la confianza social, el fomento a la igualdad, el acceso y el sentido de equidad en la comunidad donde se ubica la biblioteca pública, los cuales deben ser resultados a los que contribuya esta institución, por lo que también deben investigarse. ${ }^{7}$

\section{DESARROLLO DE LAS BIBLIOTECAS PÚBLICAS EN MÉXICO Y COLOMBIA}

México y Colombia tienen redes nacionales de bibliotecas públicas que han sido creadas y se han ido desarrollando por caminos muy distintos, además de que su tamaño y devenir también presentan grandes diferencias.

La Red Nacional de Bibliotecas Públicas en México se originó en 1983 a través de un programa nacional establecido por el gobierno federal para iniciar una estrategia educativa y cultural. En ese año, el país tenía 351 bibliotecas públicas diseminadas en todo su territorio, por lo que el Programa Nacional de Bibliotecas Públicas buscaba que al menos hubiera una biblioteca pública en los municipios que tuvieran un mínimo de población y que contaran con los servicios educativos básicos.

Con el surgimiento de la Red Nacional de Bibliotecas Públicas se crearon estructuras estatales para este tipo de bibliotecas, con una biblioteca pública central en las capitales, que se coordinaría con las bibliotecas regionales de su demarcación territorial. Estas bibliotecas regionales se ubicaron en poblaciones de tamaño medio que tuvieran alguna importancia con las comarcas circundantes. Además, dentro del espacio jurisdiccional del estado, también se instalaron bibliotecas municipales -que son las que más hay- para atender las necesidades de información inmediatas de las comunidades.

7 C. Hillenbrand (2005), "A place for all: Social Capital at the Mount Barker Community Library", South Australia, Australasian public libraries and information services, 18(2), 41-58. 
La operación de esta red mexicana se lleva a cabo a través de la corresponsabilidad entre los tres órdenes de gobierno: federal, estatal y municipal, y se encuentra manifestada en la legislación bibliotecaria de este país.

El órgano responsable de la coordinación de esta red es el Consejo Nacional para la Cultura y las Artes, que a través de la Dirección General de Bibliotecas expide la normativa a seguir, capacita a los bibliotecarios y dirige técnicamente a las bibliotecas públicas del país. La contratación de los bibliotecarios, el mantenimiento de las instalaciones y la operación directa de las bibliotecas queda a cargo de los gobiernos estatales y municipales.

La Dirección General de Bibliotecas opera dos bibliotecas: la Biblioteca de México "José Vasconcelos” y la Biblioteca Vasconcelos, que se encuentran en el Distrito Federal.

Actualmente, en México, hay 7,320 bibliotecas públicas integradas a la Red Nacional de Bibliotecas Públicas que resguardan un total de 36.5 millones de volúmenes, de las cuales 3,226 tienen en sus instalaciones equipos de cómputo y conectividad a Internet. $^{8}$

En Colombia, la Biblioteca Nacional es la encargada de coordinar la Red Nacional de Bibliotecas Públicas, y mediante esta forma se articulan e integran en un ordenamiento nacional, departamental, distrital, municipal y rural con todos sus servicios. Así, esta red opera soportada en una estructura de nodos departamentales y distritales que actúan como coordinadores y dinamizadores de todas las bibliotecas. ${ }^{9}$

8 María Josefa Santos et al., Disminuyendo la brecha digital: el nuevo papel de la biblioteca pública mexicana, México: Consejo Nacional para la Cultura y las Artes: Universidad Nacional Autónoma de México, 2012, pp. 23, 159.

9 Colombia, Ministerio de Cultura, Biblioteca Nacional, Red Nacional de Bibliotecas Públicas, disponible en: http://www.bibliotecanacional.gov. $\mathrm{co} /$ ?idcategoria $=27552$ 
Hasta 2009, la Red Nacional colombiana agrupaba 1,498 bibliotecas públicas en el territorio, las cuales eran administradas por instituciones oficiales o privadas. ${ }^{10}$

Tres hechos fundamentales debemos destacar en el desarrollo de esa red colombiana: ${ }^{11}$

1. En 1954, la apertura de la Biblioteca Pública Piloto de Medellín. Éste fue un programa de la UNESCO que más tarde alcanzaría a desarrollar el primer sistema efectivo de bibliotecas públicas en el país.

2. En 1957, la inauguración de la Escuela Interamericana de Bibliotecología con el apoyo de la Organización de Estados Americanos.

3. En 1958, el establecimiento de la Biblioteca Luis Ángel Arango, por parte del Banco de la República.

A estas instituciones de origen se suman otros procesos notables:

1. El desarrollo de una red de bibliotecas públicas por parte de las Cajas de Compensación Familiar, las cuales son un sistema privado de apoyo a las familias.

2. Los esfuerzos que ha hecho el gobierno nacional por conformar un sistema de bibliotecas públicas.

3. Las nuevas tecnologías que han cambiado los perfiles, instrumentos y operación de las bibliotecas públicas.

10 J. Hernández Toscano (2009), p. 5.; Melo (2001) reportaba en el año 2001 que el total de bibliotecas públicas -incluidas las que se integraron a la Red Nacional- sumaba 1,096 instituciones que dividió en seis categorías. Este mismo autor calculó 4.1 millones de volúmenes resguardados en estas bibliotecas públicas.

11 Jorge Orlando Melo, "Las bibliotecas públicas colombianas: ideales, realidades y desafíos”, disponible en: http://www.jorgeorlandomelo.com/biobliotecaspublicas. 
Con estos antecedentes se ha llegado a configurar un sistema de bibliotecas públicas con los siguientes componentes:

A. Bibliotecas públicas de las cajas de compensación familiar. Ésta es la red de bibliotecas públicas más grande del país.

B. La red de bibliotecas del Banco de la República.

C. La red de bibliotecas de la Biblioteca Piloto de Medellín.

D. Las redes de bibliotecas públicas departamentales y de los grandes municipios.

E. La red de bibliotecas distritales Bibliored.

Podemos notar que el desarrollo y la situación actual de las bibliotecas públicas en ambos países presenta señaladas diferencias, pues el caso de México muestra una centralización de la coordinación, una corresponsabilidad definida y una operación establecida entre los tres órdenes de gobierno en todo el territorio. En el caso de Colombia el desarrollo ha sido diverso, así como las formas de coordinación y la operación de estas instituciones. Estas distinciones seguramente provocan impactos diversos en sus comunidades.

\section{IMPACTO EN LAS BIBLIOTECAS PÚBLICAS DE MÉXICO}

De acuerdo con un estudio reciente del Instituto de Investigaciones Sociales de la UNAM, ${ }^{12}$ las bibliotecas públicas mexicanas atendieron, hasta 2011, a 31.4 millones de usuarios. ${ }^{13}$ El estudio destaca el impacto que ha tenido el Programa de Acceso a Servicios Digitales en Bibliotecas Públicas creado en 2002, y considera el uso de las tecnologías de la información y comunicación (TIC)

12 María Josefa Santos et al., Disminuyendo la brecha digital: el nuevo papel de la biblioteca pública mexicana, México: Consejo Nacional para la Cultura y las Artes: Universidad Nacional Autónoma de México, 2012.

13 Santos, op. cit., p. 23. 
en estos espacios como instrumentos o herramientas viables para mejorar la calidad de vida de las personas. Ese impacto, según el mismo estudio, se manifiesta en tres aspectos: ${ }^{14}$

1) El formativo, es decir, las habilidades tecnológicas y sociales logradas a partir del Programa, y donde destacan actividades como la búsqueda de información general y especializada, la comunicación con familiares o amigos lejanos, los cursos formales, la elaboración de tareas y trabajos escolares y pasar un rato de esparcimiento, entre otros.

2) El uso de la tecnología en actividades que contribuyen al desarrollo de los usuarios y las comunidades, como son la búsqueda de información para atender problemas de salud, para la lectura de noticias, para hacer negocios, para buscar trabajo y para realizar trámites gubernamentales.

3) Legitimar el papel de las bibliotecas públicas a través de las TIC y sus contenidos con sus usuarios, personal bibliotecario y autoridades.

Asimismo este documento de investigación indica que se percibe de manera clara que, con la llegada de las computadoras, las bibliotecas públicas mexicanas cobraron mayor importancia para la gente de las comunidades, pues ahora se les visita más y se han ido modernizando. ${ }^{15}$

Además del acceso a los recursos tecnológicos en las bibliotecas públicas, un programa con éxito que tuvo sus inicios en los años ochenta, bajo la dirección de la doctora Ana María Magaloni, es "Mis Vacaciones en la Biblioteca". Éste es un programa que consiste en la realización de actividades culturales y de fomento a la lectura durante todos los veranos y en todas las bibliotecas públicas mexicanas, aplicando el principio de "pasar un tiempo

14 Ibid., pp. 139-153.

15 Ibid., p. 141. 
lúdico y de esparcimiento en una biblioteca cercana a mi barrio u hogar". De igual forma, anualmente se realiza un concurso en el que participan jóvenes usuarios de bibliotecas públicas, quienes son invitados a leer y expresar un texto a través de dibujos. Posteriormente, se seleccionan los mejores dibujos para ilustrar un clásico de la literatura mundial dirigido a los niños y que pasa a formar parte de la "Colección Biblioteca Infantil".

También es importante destacar las 32 bibliotecas públicas centrales estatales que operan en la Red Nacional de Bibliotecas Públicas y que fungen como cabeza de los estados de la república y en el Distrito Federal. La mayoría son de grandes dimensiones arquitectónicas y con amplia capacidad para brindar colecciones y servicios. Ejemplo de ello es la biblioteca central del estado de Hidalgo, que recibe un promedio de 9,287 visitas por mes, ${ }^{16}$ y que tiene distintos servicios tradicionales junto con servicios especializados, como el área de silentes o sordomudos. También la del estado de Tabasco, que a diario atiende a 1500 usuarios en promedio ${ }^{17}$ y que cuenta con una sala de invidentes que da servicio a 50 usuarios por día.

En este contexto, la Biblioteca Vasconcelos, ubicada en la capital mexicana, recibe un promedio de más de 3000 personas diariamente -cifra que incrementa los fines de semana y los días que se organizan eventos masivos-, y ofrece una amplia gama de servicios bibliotecarios y culturales. Uno de los aspectos que la distingue es la formación de lectores y el fomento por el aprecio hacia las expresiones culturales y artísticas. De igual modo, un aspecto que caracteriza a ésta y otras bibliotecas públicas mexicanas es la oferta de talleres que brinda la Academia Mexicana de las Ciencias, lo que no sólo ha despertado el interés por la ciencia en el público de diferentes edades, sino que ha logrado modi-

16 La información fue proporcionada en septiembre de 2012 por la Dirección de Bibliotecas y Documentación del Estado de Hidalgo.

17 Los datos fueron proporcionados en octubre de 2012 por la Dirección de la Biblioteca Pública Central del Estado de Tabasco. 
ficar aspectos de su vida mediante el aprendizaje y la aplicación de conocimientos científicos en actividades de la vida cotidiana. ${ }^{18}$

Como indicamos en los ejemplos, otros servicios que han logrado impactar en personas con capacidades diferentes son las salas para invidentes, a través de la oferta de programas de lectura en voz alta, servicios de impresión en formato Braille, audiolibros, escáners parlantes y programas informáticos que convierten textos digitales en sonido y voz.

Por otro lado, un caso de impacto de colaboración entre bibliotecas públicas con el sector educativo es el Proyecto Vasconcelos, el cual busca atender necesidades de información en las comunidades más pobres y marginadas del estado de Veracruz, y que consiste en camiones adaptados con pupitres, computadoras, antenas satelitales para Internet, pizarrones electrónicos, redes inalámbricas y un equipo humano capacitado. El proyecto trabaja en cuatro áreas: educación, cultura, organización social y productividad. En 2008 recibió el premio de la Fundación Bill y Melinda Gates en el 74 Congreso Mundial de Bibliotecas e Información de la IFLA celebrado en Quebec, Canadá.

\section{IMPACTO EN LAS BIBLIOTECAS PÚBLICAS DE COLOMBIA}

Conocer el impacto de las bibliotecas colombianas nos remite a un interesante estudio del equipo de investigación sobre biblioteca pública de la Escuela Interamericana de Bibliotecología de

18 Conocidos como "Micromundos", los talleres están dirigidos a niños y jóvenes para que aprendan a desarrollar habilidades creativas, un pensamiento crítico, así como la resolución de problemas y la convivencia social. Permiten adquirir conocimientos de todas las ramas del saber a través de la exploración y del juego. Los talleres están pensados para que los asistentes lleven a cabo desde tareas como la programación de figuras geométricas, la manipulación de animaciones multimedia, hasta algunas aplicaciones de robótica. Desde 1984 la Academia Mexicana de las Ciencias, a través de su Programa de Computación para Niños y Jóvenes, imparte el taller "Micromundos" en 127 sedes -en su mayoría bibliotecas públicas- ubicadas en 15 estados de la República mexicana. 
la Universidad de Antioquia, el cual contribuyó a los trabajos de la Encuesta Internacional de Lectura en América Latina. Dicho estudio tuvo, como uno de sus objetivos centrales, difundir las experiencias exitosas de fomento de la lectura y la formación de lectores, y concibió a la promoción de la lectura y a la biblioteca pública como estrategias básicas de intervención social. ${ }^{19}$ Los resultados fueron los siguientes:

- En cuanto al acceso a materiales de lectura, las bibliotecas colombianas suelen ofrecer servicios móviles como las cajas viajeras, bibliobuses, bibliojeeps, bibliochalupas, biblioburros, bibliotaxis y bibliocorreo, rompiendo los paradigmas tradicionales de servicios bibliotecarios y sobre todo haciéndolos más divertidos, dinámicos y alegres. ${ }^{20}$

- En relación con las actividades de promoción y animación a la lectura, en las bibliotecas públicas colombianas se encuentran las horas del cuento, la lectura en voz alta, los clubes de lectura, los juegos didácticos, los talleres de lectura, y los cineclubes y la proyección de películas. Estas actividades están dirigidas en un $100 \%$ a los niños, así como para grupos escolares y de jóvenes.

- Así, una de las facetas más notables del quehacer de los bibliotecarios colombianos en materia de promoción de la lectura es, precisamente, generar en los niños el placer por asistir y utilizar la biblioteca, y que muchos niños la aprecien, sobre todo en los sectores populares. ${ }^{21}$ Por otra parte, notamos que actualmente son foco de atención los grupos sociales como los reclusos, los adultos mayores, las comunidades indígenas, las personas discapacitadas y las hospitalizadas. ${ }^{22}$

19 Didier Álvarez Zapata, Yicel Nayrobis Giraldo Giraldo et al., "Acercamiento al estado actual de la promoción de la lectura en la biblioteca pública en Colombia”, Rev. Interamericana de Bibliotecología, Medellín, Colombia, Vol. 31, Núm. 2, jul.-dic., 2008, p. 17.

20 Op. cit., p. 27.

21 Op. cit., pp. 30-31.

22 Op. cit., p. 33. 
- Así, la promoción de la lectura también se realiza en espacios públicos como las calles y los parques, las instituciones educativas, los reclusorios, los hogares infantiles y juveniles, los albergues para ancianos, las instancias sociales, los hospitales, los centros comerciales y los espacios culturales. ${ }^{23}$

- Un claro ejemplo de impacto son las bibliotecas de Bogotá y su sistema de bibliotecas Biblored, que tiene 20 bibliotecas a través de la ciudad y cuatro megabibliotecas, que sirvieron a 4.4 millones de usuarios en 2008. Es de notar que en 2002 Bibliored ganó el Premio del Acceso al Conocimiento de la Fundación Bill y Melinda Gates. ${ }^{24}$

Un caso de éstos es el de la biblioteca del Tunal, en Bogotá, que provee un espacio gratuito de inclusión e intercambio para la interacción de los ciudadanos de todos los estratos sociales. Habitantes de los barrios más pobres que nunca habían tenido acceso a una computadora, actualmente tienen información digital a través de Internet, así como películas internacionales y obras culturales, clases gratuitas en inglés, etcétera. Además, se ofrecen exhibiciones de arte de grupos indígenas, conciertos afro-colombianos y festivales artísticos. Se brindan talleres para padres y programas como "Leo con mi bebe" o "Leer en familia", que impulsan el aprendizaje continuo como una actividad familiar. La biblioteca también tiene un club de lectores en la Cárcel Distrital de Bogotá y, además, ha diseñado áreas para la participación política entre los ciudadanos y el Estado. En definitiva, el Tunal ha ayudado a sembrar un espíritu de pertenencia en una comunidad que antes era una zona desorganizada. ${ }^{25}$

23 No obstante, como en México, el impacto de la biblioteca pública colombiana aún es notable en los espacios urbanos, y todavía es mínimo en los espacios rurales.

24 Caroline McDermott, "Aproximación desde el desarrollo humano al impacto de las bibliotecas públicas en Colombia" [Reporte de investigación], Universidad de Los Andes: Colombia, 2010, pp. 9-10, en: http://www.reddebibliotecas.org.co/comunidad_bibliotecologos/Documents/McDermott_ReporteDesarrolloHumanoBibliotecas.pdf

25 Ibid. p. 20. 
Otro ejemplo es el de Medellín, que tiene un sistema de 22 bibliotecas a las que pertenecen la Biblioteca Pública Piloto de Medellín y sus seis filiales, las ocho bibliotecas de la Secretaría de Cultura Ciudadana, la biblioteca de la Contraloría Municipal, la Biblioteca EMP (Empresas Públicas de Medellín) y los cinco Parques-Biblioteca. Así, bajo el plan municipal de Parques-Biblioteca, se tienen los siguientes objetivos básicos:

a) contribuir al mejoramiento de la calidad de vida de las personas;

b) crear condiciones para el desarrollo humano;

c) propiciar la convivencia ciudadana;

d) construir espacios culturales, recreativos y educativos y

e) mejorar el acceso a la información.

Otro caso es el del Parque Biblioteca España, donde se ha logrado un impacto en el desarrollo económico del barrio de Santo Domingo, en Medellín. Este barrio es uno de los más peligrosos y pobres de la ciudad, pero en los últimos años ha cambiado por las mejoras urbanas alrededor de esta Biblioteca y por el sistema de transporte público conocido como Metrocable. De esta forma la Biblioteca se volvió una atracción turística, lo cual llevó a darle más atención a los temas de seguridad de la zona. Así, con áreas más seguras y un mercado potencial, inició todo un desarrollo microempresarial. ${ }^{26}$

El impacto más profundo es que conecta los servicios que ofrece esta biblioteca para crear vidas productivas a través de la formación del capital humano, del acceso a la información y de las oportunidades de empleo, así como por los espacios que se ofrecen para la participación comunitaria en las políticas públicas. Los programas mejoran notablemente las habilidades para el empleo de los jóvenes y adultos a través de clases y cursos que se imparten para el desarrollo de sus habilidades informativas,

26 Ibid. p.17. 
etcétera. ${ }^{27}$ También un programa denominado Medellín Digital suministra información y ayuda para hacer trámites oficiales para iniciar nuevos negocios y obtener beneficios del gobierno. ${ }^{28}$

Medellín y Bogotá muestran ejemplos de suma importancia sobre el potencial transformador de instituciones como las bibliotecas públicas en sus sociedades, y han establecido una clara visión para fomentar el desarrollo económico y crear un sentido de comunidad en algunas de sus zonas más peligrosas.

Tenemos entonces que, en Colombia, las bibliotecas públicas siguen siendo una parte importante de la lucha contra la pobreza, la exclusión, los bajos niveles educativos, la violencia y el deterioro social. De igual modo, han sido un elemento fundamental para el cambio y desarrollo urbano. ${ }^{29}$

\section{CONCLUSIONES}

Suaiden dijo que las bibliotecas públicas son importantes en América Latina porque a través de sus productos y servicios son visibles para la sociedad. ${ }^{30}$ De esta manera, el impacto de las bibliotecas públicas adquiere sentido cuando nos referimos a la inclusión social, a la diversidad de públicos que se pueden atender, a la frecuencia e intensidad del uso de los servicios, a la formación de lectores críticos, así como a la mejora de la calidad de vida de los ciudadanos y las comunidades.

27 La profesora Orlanda Jaramillo apunta que el sector donde está ubicada la Biblioteca Parque España sufre un conflicto social armado no resuelto en su totalidad; por ello, la existencia de esta biblioteca significa la ganancia de un espacio de paz y convivencia, Cfr. Jaramillo, Orlanda (2010), "La biblioteca pública, un lugar para la formación ciudadana: referentes metodológicos del proceso de investigación”. Revista interamericana de bibliotecología, 33(2), p. 307.

28 McDermott, op. cit., p. 17.

29 Ibid, p. 10.

30 Emir José Suaiden (2002), "El impacto social de las bibliotecas públicas", Anales de Documentación, Vol 5, p. 338. 
No obstante, es preciso señalar que aún prevalecen diversas barreras en las bibliotecas públicas, tanto mexicanas como colombianas, tales como las siguientes:

- La localización y la accesibilidad.

- El desconocimiento de los servicios y programas.

- La cobertura.

- Las percepciones de la gente.

Medir el impacto es una tarea de investigación que nos atañe para saber con claridad el beneficio que le aportan a la sociedad las bibliotecas públicas. Por ello, es preciso notar que estas instituciones sólo han adoptado métodos cuantitativos para medir su operación frente al valor y cantidad de sus servicios. Así, tenemos que hoy se miden las percepciones individuales en lugar de analizar las contribuciones al desarrollo de las comunidades, especialmente en términos de impacto educativo, laboral y económico. ${ }^{31}$ Siguiendo esta línea de razonamiento, tenemos que los indicadores de impacto pueden ser los siguientes:

- Desarrollo económico y social.

- Eficacia en la enseñanza y la salud.

- Lucha contra la delincuencia, la drogadicción y otros problemas sociales.

- Lucha contra el desempleo.

- Satisfacción del usuario.

Por ello una planeación estratégica mediante el uso y manejo de diagnósticos precisos y metodologías cualitativas e indicadores nos permitiría conocer el éxito o fracaso de las actividades en las bibliotecas públicas, ${ }^{32}$ pues si estas instituciones son efectivas, entonces les proporcionarán a sus ciudadanos el conocimiento y el sentido de comunidad que les permitirá desarrollar mecanismos efectivos de acción política, de integración social, progreso eco-

31 McDermott, C., op.cit., p. 15.

32 Suaiden, op.cit., p. 341. 
nómico y mejor educación, fortaleciendo permanentemente sus capacidades para que puedan escoger cómo desarrollar sus vidas.

La participación y la inclusión social son factores básicos de impacto en las bibliotecas públicas, además del apoyo que éstas brindan en la reducción de la brecha digital. Por ello, estos espacios o instituciones de convivencia son necesarios para que exista una verdadera democracia e igualdad, ya que allí encontraremos diversos valores e intereses, culturas y generaciones conviviendo y abonando a la cohesión y la pertenencia social.

En suma, se necesitan espacios donde impere la diversidad de información y la generación de conocimientos cruciales para el permanente desarrollo humano. ${ }^{33}$ Este es el potencial que, sin lugar a dudas, caracterizará a las bibliotecas públicas.

\section{REFERENCIAS BIBLIOGRÁFICAS}

Aabø, S. (2005), "The role and value of public libraries in the age of digital technologies", Journal of librarianship and information science, 37(4), 205-211.

Álvarez Zapata, D. et al. (2008), "Acercamiento al estado actual de la promoción de la lectura en la biblioteca pública en Colombia”, Revista interamericana de bibliotecología, 31(2), 13-43.

Fernández Abad, F. J. (2006), "Evolución histórica de la función social de las bibliotecas públicas", Revista general de información y documentación, 16(2), 93-110.

33 A. Varheim, (2008), "El capital social y las bibliotecas públicas: Necesidad de investigar", Boletín de la Asociación Andaluza de Bibliotecarios. p. 84. 
Fraser, B. T., Nelson, T. W., McClure, T. R. (2003), "Descripción del impacto y los beneficios económicos de las bibliotecas públicas de Florida: Resultados y aplicaciones metodológicas para trabajos futuros", Boletín de la Asociación Andaluza de Bibliotecarios, 72, 73-101.

Greenhalgh, L., Landry, C., Worpole, C. (1993), Borrowed time? The future of public libraries in the UK, Bournes Green: Comedia.

Hernández Pacheco, F. (2012), Estudio comparativo de las bibliotecas públicas de México y Colombia, México, Universidad Nacional Autónoma de México: Instituto de Investigaciones Bibliotecológicas y de la Información [en prensa].

Hernández Toscano, J. (2009), "La Red Nacional de Bibliotecas Públicas", 6 h, en: http://www.cerlalc.org/redplanes/boletin_redplanes2/imagenes/documentos/2_Red_bibliotecas.pdf

Hillenbrand, C. (2005), "A place for all: Social capital at the Mount Barker Community Library, South Australia”, Australian public libraries and information services, 18(2), 41-58.

Jaramillo, O. (2010), "La biblioteca pública, un lugar para la formación ciudadana: Referentes metodológicos del proceso de investigación”, Revista interamericana de bibliotecología, 33(2), 287313.

Johnson, C.A. (2010), "Do public libraries contribute to social capital? A preliminary investigation into the relationship", Library \& information science research, 32(2), 147-155.

Liberta Bonilla, B.E. (2007), "Impacto, impacto social y evaluación del impacto", ACIMED, 15(3), en: http://scielo.sld.cu/pdf/ aci/ v15n3/aci08307.pdf 
McDermott, C. (2010), Desarrollo bumano y las bibliotecas públicas en Colombia, Bogotá: CIDER; Universidad de los Andes.

Melo, J. O. (2001), "Las bibliotecas públicas colombianas: Ideales, realidades y desafíos", BLAA digital: Biblioteca Luis Ángel Arango, en: http://www.jorgeorlandomelo.com/biobliotecaspublicas.htm, 29 sept. 2012.

Ponjuán Dante, G. (1998), Gestión de información en las organizaciones: principios, conceptos y aplicaciones, Santiago de Chile: CECAPI.

Santos, María Josefa et al. (2012), Disminuyendo la brecha digital: el nuevo papel de la biblioteca pública mexicana, México, Consejo Nacional para la Cultura y las Artes: Universidad Nacional Autónoma de México.

Suaiden, E. J. (2002), "El impacto social de las bibliotecas públicas", Anales de documentación, 5, 333-344.

Varheim, A. (2008), "El capital social y las bibliotecas públicas: Necesidad de investigar", Boletín de la Asociación Andaluza de Bibliotecarios, 90-91, 71-87. 


\title{
Investigación aplicada a la preservación y organización de documentos institucionales: la UNAM un mundo por ordenar
}

\author{
BRENDA CABRAL \\ Universidad Nacional Autónoma de México
}

El mundo está en las manos de aquellos que tienen el coraje de soñar y correr el riesgo de vivir sus sueños.

P. Coelho

No hay como el orden para enseñar a ganar tiempo.

Anónimo

\section{INTRODUCCIÓN}

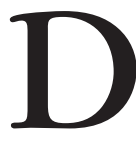

ar el acceso a la información generada por una institución es una labor que no sólo tiene relevancia para las propias dependencias que la conciben, sino que tiene importancia a nivel nacional y se basa en dos leyes: la Ley de Transparencia y Acceso a la Información y la Ley Federal de Archivos; esta última, publicada el 23 de enero de 2012 en el Diario Oficial de la Federación, establece las disposiciones para la organización y conservación de los archivos en posesión de los Poderes de la Unión, de los organismos constitucionales autónomos y de los organismos con autonomía legal.

Dice Jorge Carpizo McGregor que "Hoy en día cumplir con el derecho a la información y el acceso a la documentación pública por parte de las universidades públicas autónomas es una obliga- 
ción constitucional y legal para éstas. Pero, es algo más; es una responsabilidad ética, porque las universidades públicas deben ser y dar ejemplo de transparencia, la cual es un principio propio de las democracias". 1

En este marco, la UNAM tiene la responsabilidad de dar orden y sistematización a la información institucional, ya que si bien ella cuenta con ordenamientos que regulan el trabajo archivístico, como el Acuerdo para la Protección, Uso y Conservación del Patrimonio Histórico Documental de la UNAM, de 1998 y el Manual de Archivo de la UNAM, de 2004, así como con el Reglamento de Transparencia, Acceso a la Información y Protección de Datos Personales para la UNAM, de 2011 -este último, acorde con la Ley de Transparencia y Acceso a la Información-, es necesario, como supo ver el Comité encargado de la realización del cuadro de clasificación, reconocer la dinámica del entorno y promover un nuevo enfoque para la definición de agendas que retome el trabajo precedente y se enriquezca con una visión a largo plazo.

En enero de 2012 comenzó a definirse una agenda de organización, recuperación y preservación de los documentos generados por cada una de las dependencias que pertenecen a la UNAM, partiendo de la identificación de problemáticas de diversas índoles, entre ellas, la de gestión, las tecnológicas y metodológicas, y tomando en cuenta un diagnóstico realizado para cada archivo o archivos pertenecientes a cada dependencia de la UNAM.

Por ello, a través del proyecto de creación y operación del Sistema Institucional de Archivos de la UNAM, se da inicio a una serie de estudios con miras a establecer la Agenda Prospectiva de gestión de los documentos.

Este proceso se estructuró en tres fases: ciclo piloto, en el cual participaron las autoridades; ciclo uno, donde se delimitaron los problemas que hay que enfrentar a partir del diagnóstico de la información con el que cuenta la UNAM, y el ciclo dos, que aborda los cuadros de clasificación y la formación de recursos humanos,

1 Jorge Carpizo McGregor, "Transparencia, Acceso a la información y Universidad Pública Autónoma”, en La transparencia en las Universidades Públicas de México, Artículo xIX, México, 2009. 
cuyas agendas se consolidarán el presente año con un diagnóstico realizado a cada uno de los archivos existentes en la UNAM.

La participación de diferentes entidades ha permitido consolidar una metodología en la UNAM que priorice las necesidades de organización de forma contextualizada. De este modo, cada entidad ha tenido un rol particular: el archivo general de la UNAM ha suministrado los espacios y el personal que lleva la logística de la investigación; el archivo histórico ha liderado y coordinado el proceso; las autoridades han aportado herramientas y asesoría en vigilancia, y también han participado los consultores externos, el abogado general, etcétera. Con la coordinación de los cuatro primeros estudios piloto, se ha obtenido la metodología para analizar y diagnosticar las cadenas productivas y la implementación de la prospectiva para construir las agendas de gestión.

\section{IMPORTANCIA DE LA ORGANIZACIÓN DE ARCHIVOS}

Esta investigación es relevante para el Instituto de Investigaciones Bibliotecológicas y de la Información (IIBI) porque la información que se conserva en los documentos que conforman los archivos es imprescindible para la administración y la cultura, así como para la toma de decisiones basadas en antecedentes. Pasada su vigencia, estos documentos se convierten potencialmente en parte del patrimonio cultural y de la identidad nacional. Su importancia surge a partir del valor que tienen para:

- La administración.

- La investigación.

- La comunidad y el Estado.

- El desarrollo económico y social.

- El desarrollo científico y tecnológico.

- El fomento de la cultura.

- El desarrollo de la identidad nacional. 
La UNAM es una de las instituciones más grandes del país y la instancia educativa más importante. Contar con un archivo es esencial para mantener una organización centralizada y un control sobre la infinita cantidad de documentos que se mueven en cada una de sus dependencias.

No es fácil poner orden en el mundo documental que conforma esta casa de estudios; por eso, es necesario planear detalladamente y establecer propuestas, crear limitantes y reglas, determinar funciones $\mathrm{y}$ formar recursos humanos adecuados para, de este modo, no sólo originar sino mantener el orden del archivo a través del tiempo.

\section{PROBLEMAS IDENTIFICADOS}

- Falta de recursos humanos calificados.

- Necesidad de uniformidad en el manejo de términos archivísticos.

- Desconocimiento de las leyes y normativas por parte de algunas autoridades.

- Falta de sensibilización sobre el tema de algunas dependencias.

- Carencia de recursos para ordenar y sistematizar la información institucional.

ORGANIZACIÓN DEL SIA DE LA UNAM ACORDE A LA LEY FEDERAL DE ARCHIVOS

Se planteó una forma de organización para el Sistema Institucional de Archivos (SIA) de la UNAM, que quedó del siguiente modo: 


\section{Profesionalización}

Es necesario determinar el personal en cuyas manos quedarán los archivos. Por esto es necesario especificar qué es la profesionalización. Ésta maneja tres aspectos:

- La experiencia.

- Los conocimientos.

- Las habilidades y actitudes.

En el área de las humanidades y ciencias sociales se pretende formar a profesionistas aptos para el saber y el actuar; esto es, lograr que no actúen sin analizar, pensar y profundizar, así como no se estancarse en la teoría sino saber llevar su conocimiento al entorno. Deben estar habituados a trabajar en equipos multidisciplinarios y a presentar planes de trabajo acordes con las necesidades de las instituciones en que se generan los documentos.

Cabe recalcar que la participación en el proyecto que a continuación se describe nos permitirá conocer los procesos y tareas que se llevan a cabo en los distintos archivos de la UNAM, así como las diversas herramientas utilizadas; esto nos ayudará a seleccionar las buenas prácticas para desarrollar un proyecto de investigación en el que se propongan los métodos y modelos para organizar archivos de índole similar, tomando en cuenta la información obtenida en dicha investigación.

\section{Objetivo del proyecto}

La labor del Sistema Institucional de Archivos es organizar, conservar, salvaguardar, describir, facilitar el acceso a los documentos y difundir el patrimonio documental universitario. Para lograr todo esto es necesario:

- Definir políticas, lineamientos, responsabilidades y procedimientos para los archivos de trámite, concentración e históricos. 
Agendas de Investigación en Bibliotecología...

- Generar el Cuadro de Clasificación Archivística de la UNAM.

- Crear un manual de procedimientos e instructivos para la Clasificación.

- Asegurar que el personal constitutivo del Sistema cuente con conocimientos y experiencia archivística.

- Supervisar la operación de las políticas de archivo en la unidades universitarias.

- Incorporar software y hardware para la gestión documental, y prever su actualización.

- Crear un sistema de gestión electrónica de los documentos que se producen en la UNAM.

\section{DESARROLLO DE LA AGENDA DE INVESTIGACIÓN}

Primera etapa

Designación del Comité

Para poder iniciar la labor fue necesario designar un Comité técnico para la conformación del Sistema Institucional de Archivos de la UNAM. Éste quedó establecido del siguiente modo:

Coordinadores del Comité:

- Mtro. Miguel Robles Bárcena, Secretario de Servicios a la Comunidad.

- Lic. Eduardo C. Cacho Silva, Director General de Servicios Generales.

Miembros del Comité:

- CP Agustín Mercado, Subdirector de Certificación y Control Documental.

- Dra. Brenda Cabral Vargas, Investigadora del Instituto de Investigaciones Bibliotecológicas y de la Información. 
- Lic. Elizabeth Meza Jerónimo, Subdirectora de Servicios y Prestaciones de la Dirección General de Personal.

- Mtra. Sandra Peña Haro, Coordinadora del Archivo Histórico.

- Dra. Gloria Villegas Moreno, Directora de la Facultad de Filosofía y Letras.

- Mtro. José Agustín Hernández Ibarra, Jefe del Departamento del Archivo General.

Se definieron, a su vez, los compromisos y responsabilidades de los miembros.

\section{Delimitación de los conceptos}

Dentro de esta primera etapa se partió de la necesidad de contar con un lenguaje común, por lo que se fueron conceptualizando algunos términos que se usarían durante esta investigación. Entre los conceptos analizados y descritos están:

Archivo: se refiere a uno o más conjuntos de documentos acumulados por una persona o institución pública o privada.

Documento: se entiende como tal toda información producida como testimonio de los actos humanos.

Documento de archivo: es el testimonio material de un hecho. Se denomina de este modo a toda expresión en lenguaje natural o convencional y cualquier otra expresión gráfica, sonora o en imagen, recogida en cualquier tipo de soporte material o informático.

Para este trabajo se decidió nombrar como documento a todo aquel documento de archivo perteneciente a la Universidad.

Tipos de archivo: archivo de trámite, archivo de concentración y archivos históricos. 
Entre muchos otros términos más que se fueron describiendo conforme se elaboraban algunos instrumentos.

A continuación (Tabla 1), se presenta el cronograma elaborado por el comité encargado de la logística de la organización y de la recuperación de documentos elaborados a través de algunos medios o recursos digitales.

Tabla 1.

Proyecto de actividades para la creación del SIA de la UNAM

Se planteó el camino a seguir para poder generar la organización del Sistema Institucional de Archivos de la UNAM. El cronograma de actividades quedó de la siguiente manera:

\begin{tabular}{|c|c|c|c|c|c|c|c|c|}
\hline \multirow[b]{2}{*}{ ACTIVIDAD } & \multicolumn{5}{|c|}{2012} & \multicolumn{3}{|c|}{2013} \\
\hline & $\begin{array}{l}\text { 응 } \\
\text { D } \\
\text { 운 }\end{array}$ & 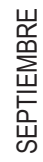 & 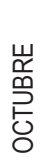 & 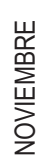 & 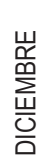 & 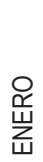 & $\begin{array}{l}\text { 오 } \\
\text { 㟧 } \\
\text { 出 }\end{array}$ & 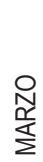 \\
\hline $\begin{array}{l}\text { Curso Introductorio para la elaboración de instru- } \\
\text { mentos. }\end{array}$ & $\begin{array}{l}\text { del } 27 \\
\text { al } 31\end{array}$ & & & & & & & \\
\hline $\begin{array}{l}\text { Elaboración del Cuadro General de Clasificación. } \\
\text { Fecha límite: junio de } 2013 .\end{array}$ & & $x$ & $x$ & $X$ & & $x$ & & \\
\hline $\begin{array}{l}\text { Elaboración del Catálogo de disposición documental. } \\
\text { Fecha límite: junio de } 2013 .\end{array}$ & & & & & & $x$ & $x$ & \\
\hline $\begin{array}{l}\text { Elaboración de los Inventarios documentales. Fecha } \\
\text { límite: junio de } 2013 .\end{array}$ & & & & & & & $x$ & $x$ \\
\hline $\begin{array}{l}\text { Elaboración de la guía simple de archivos. Fecha } \\
\text { límite: junio de } 2013 \text {. }\end{array}$ & & & & & & $x$ & $x$ & \\
\hline $\begin{array}{l}\text { Desarrollo de aplicaciones de tecnologías de la infor- } \\
\text { mación para el manejo y control de archivos. }\end{array}$ & & & & & & $x$ & & \\
\hline
\end{tabular}

\section{Curso introductorio}

Antes que nada, fue necesario tomar un curso que planteaba las bases de la archivística, el cual debió cursarse tanto por los miembros del Comité como por los encargados de archivos de la UNAM, ya fueran administrativos, de concentración o históricos.

Se llevó a cabo este curso de formación partiendo de la necesidad de formar recursos humanos para que organicen de manera 
óptima cada uno de los archivos que se manejan dentro de la UNAM, por lo que se plantea generar una serie de contenidos que conformen un curso de formación en esta materia.

El curso se aplicó desde el 27 hasta 31 de agosto, y abordó diversas temáticas relativas: los conceptos generales de la archivística; la legislación y normatividad de la misma; la organización de archivos y documentos; la descripción de estos mismos; la valoración de documentos y series documentales, así como su transferencia, selección y depuración, y los documentos electrónicos de archivo.

\section{Creación del Cuadro de clasificación archivística}

El cuadro de clasificación es una estructura jerárquica y lógica que refleja las funciones y las actividades de una organización, las cuales generan la creación o recepción de documentos.

Es un sistema que organiza intelectualmente la información y permite situar los documentos en sus relaciones los unos con los otros para constituir eso que se llama, generalmente, expedientes.

El sistema de clasificación es un modelador de información elaborado a partir de las funciones de la organización; tiene como ventaja el hecho de normalizar la denominación de los expedientes.

El requisito previo indispensable para la elaboración de un sistema de clasificación es, pues, un perfecto conocimiento de las funciones del organismo que genera los documentos.

¿Cómo se elabora un cuadro de clasificación?

Para elaborar un cuadro de clasificación, se deben considerar:

- Los instrumentos jurídicos, de organización y de normatividad de la dependencia o entidad.

- Los esquemas de clasificación existentes.

- Los recursos con que se cuenta. 
El cuadro de clasificación debe delimitar los documentos a clasificar, poseer unicidad, y basarse en las atribuciones o funciones de la dependencia o entidad, cuya permanencia garantice una clasificación segura y estable; asimismo, debe permitir el crecimiento de sus secciones y series sin romper su estructura; debe ser universal y flexible para ser adoptado en todos los supuestos posibles. De este modo, se establecerán divisiones precisas y necesarias sin tener que descender a subdivisiones excesivas.

En esta etapa se obtuvieron fuentes de información que proporcionaran antecedentes sobre algunos cuadros de clasificación existentes.

Así, siguiendo como modelo el cuadro de clasificación de las universidades de Puebla, Sonora y Navarra, y teniendo en cuenta los posibles archivos de la UNAM, se generó un ejemplo de posible clasificación acorde con estas instituciones; a continuación (Tabla 2) se muestra un fragmento de éste.

Tabla 2

\begin{tabular}{|c|c|c|c|c|}
\hline Documentos UNAM & & $\begin{array}{l}\text { Universidad } \\
\text { de Puebla }\end{array}$ & 1 & $\begin{array}{c}\text { Universidad } \\
\text { de Sonora } \\
\text { Gestón administrativa }\end{array}$ \\
\hline & $1 \mathrm{C}$ & Legislación & $1 \mathrm{C}$ & Legislación \\
\hline \multirow[t]{2}{*}{$\begin{array}{l}\text { Dictamen de proyectos } \\
\text { de reglamento interno }\end{array}$} & $1 \mathrm{C} .2$ & $\begin{array}{l}\text { Programas y proyectos sobre } \\
\text { legislación }\end{array}$ & 1C.1 & Proyectos normativos \\
\hline & $3 \mathrm{C}$ & $\begin{array}{l}\text { Programación, organización y } \\
\text { presupuesto }\end{array}$ & $3 C$ & $\begin{array}{l}\text { Programación, organización } \\
\text { y presupuesto }\end{array}$ \\
\hline \multirow[t]{2}{*}{$\begin{array}{l}\text { Proyecto de presupuesto } \\
\text { anual }\end{array}$} & $3 C .18$ & $\begin{array}{l}\text { Programas y proyectos en } \\
\text { materia presupuestaria }\end{array}$ & $3 C .7$ & $\begin{array}{l}\text { Proyectos en materia de } \\
\text { presupuestación }\end{array}$ \\
\hline & $11 \mathrm{C}$ & $\begin{array}{l}\text { Planeación, información, } \\
\text { evaluación y políticas }\end{array}$ & $11 \mathrm{C}$ & $\begin{array}{l}\text { Planeación, información, } \\
\text { evaluación y políticas }\end{array}$ \\
\hline Plan de desarrollo & 11C.6 & Plan de desarrollo institucional & $11 \mathrm{C} .2$ & Plan de desarrollo institucional \\
\hline Informe anual de trabajo & 11C.11 & Informes de labores & 11C.5 & Informe anual \\
\hline $\begin{array}{l}\text { Evaluación de los infor- } \\
\text { mes anuales del personal } \\
\text { académico }\end{array}$ & $11 \mathrm{C} .12$ & $\begin{array}{l}\text { Informes académicos de } \\
\text { evaluación y políticas }\end{array}$ & $11 \mathrm{C} .7$ & $\begin{array}{l}\text { Indicadores y evaluación de } \\
\text { actividades }\end{array}$ \\
\hline Políticas de investigación & $11 \mathrm{C} .2$ & $\begin{array}{l}\text { Programas y proyectos en ma- } \\
\text { teria de planeación y políticas }\end{array}$ & $11 \mathrm{C}$ & $\begin{array}{l}\text { Planeación, información, } \\
\text { evaluación y políticas }\end{array}$ \\
\hline
\end{tabular}


Investigación aplicada a la preservación y organización...

\begin{tabular}{|l|l|l|}
\hline \multicolumn{1}{|c|}{ UNAM } & & \multicolumn{1}{|c|}{ Universidad de Navarra } \\
\hline & $\mathrm{I} 100$ & Normativa y asuntos jurídicos \\
\hline Dictamen de proyectos de reglamento interno & $\mathrm{I} 103$ & Normas de desarrollo y reglamentos \\
\hline $\begin{array}{l}\text { Lineamientos generales para la creación de nuevos institu- } \\
\text { tos y centros del área correspondiente }\end{array}$ & $\mathrm{I} 103$ & Normas de desarrollo y reglamentos \\
\hline & $\mathrm{J} 100$ & Gestión de los recursos académicos \\
\hline Evaluación de los informes anuales del personal académico & $\begin{array}{l}\text { K 128 } \\
\text { K 133 }\end{array}$ & $\begin{array}{l}\text { Evaluación académica } \\
\text { Evaluación docente }\end{array}$ \\
\hline & K100 & Organización de la docencia \\
\hline Programas anuales de trabajo del personal académico & K 101 & Programación universitaria \\
\hline & L100 & Gestión de la investigación \\
\hline Elaborar proyectos e iniciativas & L110 & Proyectos de investigación \\
\hline Planes y programas de investigación & L110 & Proyectos de investigación \\
\hline
\end{tabular}

Segunda etapa

\section{Evaluación}

- Universo de dependencias analizadas: 174.

- Han contestado: 50 dependencias.

- Se sabe que se cuenta con: 437 archivos en las dependencias.

Para poder tener una idea de la documentación que se maneja en la UnAm, el Comité Técnico para la Conformación del Sistema Institucional de Archivos envió un cuestionario a las diversas dependencias de la Universidad.

Este cuestionario preguntaba la cantidad de archivos existentes en la dependencia, su localización física, el nombre del personal responsable de los mismos, el tipo de archivo, su actualidad, los usuarios del mismo, la estructura organizativa, las normas que regulaban su funcionamiento, los tipos de documentos que conformaban el archivo, la cantidad aproximada de documentación del archivo, las condiciones físicas en que se encontraba, las me- 
didas de preservación, conservación y seguridad, los programas archivísticos usados, y la existencia de actividades de digitalización documental.

Estos datos permitieron obtener una idea acerca de las circunstancias, los tipos de archivos, la cantidad de documentos y el personal que labora con los mismos. Todo esto para poder iniciar con la elaboración formal del proyecto.

\section{Tercera etapa}

En esta etapa se busca:

- Combinar algún otro instrumento para la obtención de información sobre el estado actual de los archivos.

- Analizar los resultados.

- Formar recursos humanos calificados en relación con el manejo de documentos archivísticos tanto impresos como digitales.

Funciones del personal encargado del manejo del archivo

Es necesario designar e instruir al personal que quedará encargado del archivo para que éste pueda funcionar correctamente no sólo al principio, sino a lo largo del tiempo. Este personal debe estar capacitado para:

- Adoptar programas para administrar de manera correcta el servicio de consulta y la conservación de documentos, con sujeción a las pautas y principios establecidos por la ley y las normas internas.

- Proponer un plan de capacitación para los recursos humanos de su área.

- Sugerir políticas, planes y programas para la selección, eliminación, transferencia, conservación y limpieza anual del archivo y verificar su cumplimiento conforme a las normas legales. 
- Responder por el correcto manejo de recursos del archivo.

- Proponer procedimientos o instrumentos requeridos para el óptimo funcionamiento del archivo.

- Recibir las transferencias documentales de las diferentes dependencias.

- Revisar los listados enviados por las dependencias.

- Organizar los archivos por años y por dependencia.

- Facilitar la consulta de los documentos que reposan en el archivo.

- Administrar, controlar y custodiar los bienes y el recurso humano asignado para el cumplimiento de sus funciones y las demás que le sean asignadas que correspondan a la naturaleza del grupo.

Un tema que no se puede dejar pasar por alto al llevar a cabo esta investigación es observar si existe en alguna de las dependencias valoración de los documentos, debido a que esto nos va a permitir saber qué documentos deben permanecer en nuestra colección y cuáles no, así como el tiempo en que deben estar en cada uno de los diferentes tipos de archivo: trámite, concentración e histórico. Pero antes de conocer esto mencionaré algo de los fundamentos de esta temática y algunas sugerencias para llevar a cabo dicha actividad.

Ciclo vital y valoración de los documentos

El ciclo vital de los documentos depende de si su importancia es inmediata o histórica. Las fases básicas de la gestión de documentos son:

- Primera fase: nacimiento y elaboración de documentos en los archivos de gestión.

- Segunda fase: utilización y mantenimiento. 
Esta fase comprende la utilización, control y almacenamiento de los documentos en el archivo central. Se caracteriza por asegurar:

- la disponibilidad de la información y los documentos ordinarios;

- la utilización a bajo costo de la información y los documentos ordinarios;

- la selección de material auxiliar, equipos y lugar de almacenamiento de los documentos adecuados a la frecuencia y a la naturaleza de su utilización.

- Tercera fase: conservación y eliminación

- Implica decir qué documentos se deben conservar como testimonio del pasado y cuáles se deben destruir. En el segundo caso, en cuánto tiempo se deben conservar por razones administrativas o jurídicas.

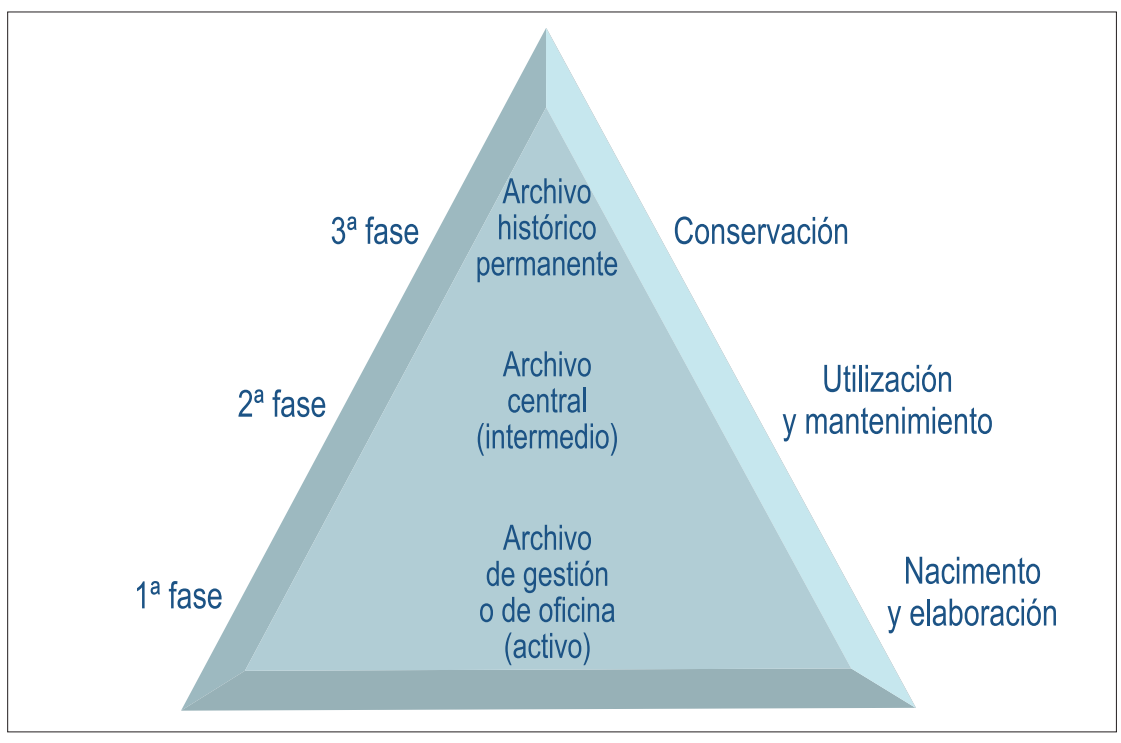

Gráfica 1.

Fuente: Manual de Archivo y Correspondencia del Instituto Nacional de Salud de Bogotá. 2005. 
En su artículo "Criterios para la valoración y selección de la documentación sobre la educación en México", Federico Lazarín Miranda ${ }^{2}$ delimita la valoración de documentos en los siguientes pasos:

- Valoración primaria: consiste en separar la información administrativa, legal o contable (fiscal). A partir de esto se delimita la utilidad del documento. Los documentos administrativos, por ejemplo, dejan de tener valor en, aproximadamente, 1 a 3 años. Al concluir este lapso los documentos deben almacenarse durante un tiempo de guarda precaucional.

La información legislativa y administrativa que generan las instituciones suele ser inicialmente información muy activa; no obstante, con el tiempo, deja de ser usada y muchas veces queda abandonada en cajas, en los rincones más olvidados. Es menester que esto no suceda y, para ello, todo documento debe trasladarse a una unidad de archivo de concentración, donde esté a disposición durante su fase semiactiva. Al acabar un determinado lapso de tiempo, estos documentos deben seleccionarse, en cuanto a su utilidad institucional y social, para pasar a formar parte de un archivo histórico o recibir su baja definitiva.

- Valoración secundaria: En esta etapa se establece si un grupo documental merece ser conservado o eliminado.

Proceso de valoración:

- Se establece la procedencia institucional del grupo documental.

- Se determina el volumen del acervo para saber el espacio que ocupa.

2 Federico Lazarín Miranda, "Criterios para la valoración y selección de la documentación sobre la educación en México”, en Entre Historiadores y Archivistas: el dilema de la valoración documental, Archivo General de la Nación, México, 1995. 
- Se precisa la tipología de los soportes materiales que lo conforman.

- Se detalla el estado de organización del acervo y el tipo de clasificación.

- Se señalan los elementos descriptivos con que cuenta.

- Se delimita el periodo de tramitación que abarca la documentación.

- Se hace una descripción detallada de la información que contiene.

- Se mencionan grupos documentales afines, lugar de procedencia y posibles restricciones públicas.

- Se aplica la valoración primaria,

- Se aplica la valoración secundaria.

Se detalla la existencia de cualquier tipo de reproducción que se haya hecho del grupo documental.

A través de este proceso se busca responder a la pregunta de si la información posee utilidad social. En caso de ser así, se almacena el grupo en el archivo histórico. De no cumplir con este requisito, se elimina físicamente la documentación.

\section{REFLEXIONES FINALES}

La organización de los archivos en la UNAM no puede llevarse a cabo sin tener una investigación que ayude en la toma de decisiones debido a que para poder planear se requiere de información confiable y actual.

La investigación juega un papel muy importante para la archivística, pues con ella identificamos muchos de los problemas que surgen a partir de la organización y acceso a los documentos emitidos por instituciones tanto públicas como privadas; asimismo, identificamos las posibles soluciones, haciendo hipótesis, tomando decisiones y viendo hacia el futuro. 
Al ver las posibles causas de los problemas se logra ver los factores que hacen que una acción sea repetitiva, se crean hipótesis, se miden los fenómenos, se les dan una serie de comparaciones e interpretaciones a los resultados obtenidos en función de los conocimientos actuales, teniendo en cuenta las variables que pueden haber influido en el resultado.

Con todo lo anterior, los procedimientos que se recomienden deben ser los necesarios y los criterios de valoración deben ser observados puntualmente; por ello, también es recomendable respaldarse en los reglamentos, en la normativa más adecuada, así como en los lineamientos internos de cada dependencia de la UNAM, los cuales permitirán diferenciar y precisar tanto las actividades que se llevan a cabo -determinando su trayectoria institucional-, como el proceso de dictaminación requerido para que la documentación sea valorada por parte de las dependencias.

Es a través de la profesionalización de los recursos humanos como se logrará facilitar el acceso a la información y, con ello, en algunos casos, generar nuevo conocimiento.

La organización de la información generada por las instituciones, así como la valoración de los documentos, facilitará el acceso y la preservación a lo que hay de verdadero y de valioso y, desde luego, orientarlo para beneficio de la sociedad, ya que de nada sirve que exista conocimiento teórico cuando no es aplicado en nuestra sociedad.

En esta investigación entran en juego varias temáticas que no sólo tienen que ver con la parte de gestión o la administrativa, sino con aspectos de índole legal, tecnológico, de seguridad y hasta político. En este último, tendríamos que analizar más a profundidad las exclusiones al ejercicio del derecho de acceso, debido a que el amplio margen de discrecionalidad y la cuestión de intereses públicos no son entendidos por todos de la misma forma. Éste es un reto para trabajos de investigación posteriores que se deja plasmado debido al nivel de importancia que tiene y a la falta de profundidad que se le ha dedicado a pesar de su relevancia.

El Instituto de Investigaciones Bibliotecológicas y de la Información debe estar al tanto de lo que la sociedad demanda 
desde el punto de vista de la información; requiere, en relación a la temática organizacional, abrir líneas en las cuales se reexaminen los archivos y se estudie cómo la cambiante estructura de las instituciones y las sofisticadas tecnologías de información están afectando la naturaleza de la documentación, y cómo, por ende, se está perdiendo mucha información. Por esto se requiere proponer los mecanismos más idóneos para que puedan ser recuperados y protegidos todos los documentos que se encuentran tanto de manera impresa como digital, esto con miras a que puedan ser utilizados a futuro por la sociedad.

\section{REFERENCIAS BIBLIOGRÁFICAS}

Carpizo McGregor, Jorge, "Transparencia, Acceso a la información y Universidad Pública Autónoma”, en La transparencia en las Universidades Públicas de México, Artículo XIX, México, 2009.

Lazarín Miranda, Federico, "Criterios para la valoración y selección de la documentación sobre la educación en México”, en Entre Historiadores y Archivistas: el dilema de la valoración documental, Archivo General de la Nación, México, 1995.

Manual de Archivo y Correspondencia del Instituto Nacional de Salud de Bogotá, 2005.

Ramos Ramos, Leonor, Los documentos de archivo: cómo se accede a ellos, Ediciones Trea, España, 2011.

Ruiz-Daza Cruz, María Elena, Patricia Galeana de Valadés, Entre historiadores y archivistas: el dilema de la valoración documental, AGN, México, 1995. 


\title{
Perspectivas de análisis de las competencias tecnológicas en la formación de profesionales en ciencias de la información
}

\author{
Julio CÉSAR Rivera Aguilera \\ Y LUIS ROBERTO RIVERA AgUILERA \\ Universidad Autónoma de San Luis Potosí, México
}

\section{INTRODUCCIÓN}

no de los retos a los que se enfrentan las instituciones de
educación superior en la actualidad es brindar una res-
puesta oportuna y pertinente a las demandas que les plantea la sociedad.

Tales demandas obedecen a la necesidad constante de adecuar los perfiles profesionales en todas las áreas del conocimiento a fin de garantizar que los niveles de desempeño correspondan a los requerimientos del sector laboral.

El caso de las ciencias de la información no es la excepción; razón por la cual los programas educativos formales habrán de mantenerse en revisión permanente, de manera tal que se lleven a cabo las reformas y actualizaciones curriculares que sean acordes con las exigencias de los sectores productivo y el de servicios.

Para las instituciones educativas del sector público lo anterior representa, por un lado, un enorme desafío y, por otro, una oportunidad de corresponderle a la sociedad a través de la formación de profesionales que posean una visión distinta del mundo y de su ámbito de desempeño laboral. 
En pleno auge de la sociedad del conocimiento, los profesionales en ciencias de la información habrán de contar con una serie de conocimientos, habilidades y actitudes que les permitan abonar al desarrollo de su entorno, particularmente en materia de tecnologías de información y comunicación (TIC), ya que estudios recientes sobre el mercado de trabajo, tanto en América Latina como en España, arrojan entre sus resultados la carencia de competencias tecnológicas bien fundamentadas y pertinentes que se requieren para enfrentar el contexto social que nos plantea el siglo XXI.

El plan de trabajo inicial que se presenta a continuación pretende contribuir en el fortalecimiento y consolidación del perfil profesional de los egresados de las áreas de ciencias de la información, a través de las propuestas que de él se deriven; de no hacerlo, se corre el riesgo de ser invadidos y, en el peor de los casos, de ser reemplazados por profesionistas de áreas afines o similares, lo que pondría en peligro la permanencia de los programas académicos que actualmente se ofertan.

\section{MARCO DE REFERENCIA}

Uno de los aspectos importantes que dan origen al tema de las competencias es el fenómeno conocido como globalización. Para entender su origen, es preciso señalar que proviene del término global, lo que hace alusión al planeta Tierra y, por tanto, puede ser sustituida por el concepto de mundialización o universalización. La globalización se visualiza como un fenómeno mundial, una fusión de procesos económicos, culturales e ideológicos transnacionales que conduce a que un país penetre en el otro (Mittelman, 1997). La globalización puede entenderse, también, como sinónimo de universalización, aunque el término es empleado para definir la ubicuidad de las nóveles relaciones económicas constitutivas de un mercado mundial supuestamente transparente, fluido, sin fronteras (Montero, 1996). Entonces, la 
globalización es el fenómeno que genera la apertura y el intercambio entre las naciones, no sólo en el aspecto comercial, sino también en el plano cultural, económico, ideológico y, por ende, el educativo. Este fenómeno global se visualiza también como un proceso de homogenización creciente a nivel económico, social y cultural (Cox, 1997).

La globalización como fenómeno social ha sido vista como un proceso que, desde su aparición, ha recorrido una época en la cual han surgido, entre otras cosas, una nueva ética sobre la vida, la educación, la economía, el trabajo, la cultura, las formas de pensar y de ver la vida social. Este fenómeno ha logrado imponer a nivel social una nueva ética global que da como resultado la aparición de valores más de índole individualista, lo que de cierta manera genera en la sociedad tensión en tanto que debilita los límites de la interacción y de la pacificación; entonces, la educación debe desempeñar un papel estratégico y lograr que a nivel social se dé la interacción entre los individuos y que ello logre que cada persona transite en busca de sus objetivos, sin trasgredir los derechos de sus semejantes.

Lo anterior permite hacer una contextualización que lleve a entender la educación superior en un ambiente global, económico y social cambiante, lo que obliga a replantearse los fines del proceso enseñanza-aprendizaje. Dicho contexto tiene como origen la aparición de nuevos elementos que redefinen el quehacer del proceso educativo; en este sentido, y respondiendo a los retos que plantean los nuevos escenarios laborales flexibles y cambiantes, es preciso comentar lo referente a las competencias, las cuales se conciben como el conjunto de comportamientos socioafectivos y de habilidades cognoscitivas, psicológicas, sensoriales y motoras que permiten llevar a cabo adecuadamente un desempeño, una función, una actividad o una tarea (Morin, 1999). La Organización Internacional del Trabajo (OIT) menciona respecto a la competencia que es la capacidad afectiva para llevar a cabo exitosamente una actividad laboral plenamente identificada (OIT, 2004). Competencia también se conceptualiza como un sistema de conocimientos conceptuales y de procedimientos organizados 
en esquemas operacionales que permiten, dentro de un grupo de situaciones, la identificación de tareas-problema y su resolución por una acción eficaz (Tremblay, 1994). Por otro lado, las competencias se relacionan con la capacidad de actuar inteligentemente en situaciones que son lo suficientemente nuevas y únicas y que requieren de una respuesta conveniente concebida in situ (Elliot, 1991). Las competencias son la acción que integra diversos componentes de aprendizaje, que movilizan e integran los distintos componentes del saber, e implican actuaciones en situaciones complejas (Zabala, 2007). Para el Centro Nacional de Evaluación para la Educación Superior (CENEVAL, 2005), las competencias son la capacidad para realizar una actividad o tarea profesional determinada que implica poner en acción en forma armónica diversos conocimientos (saber), habilidades (saber hacer) y actitudes y valores que guían la toma de decisiones (hacerlo).

En este sentido, es conveniente mencionar las propuestas que han surgido a nivel internacional relacionadas con el tema de las competencias. La primera de ellas fue presentada por la Organización para la Cooperación y Desarrollo Económico (OCDE), que propuso en 1999 un programa titulado DeSeCo (Definition and Selection of Competencies: Theorical and Conceptual Foundations; Definición y selección de competencias clave: bases teóricas y conceptuales). Dicho programa tiene como objetivo central identificar un conjunto de competencias necesarias para niños y adultos, con el propósito de llevar vidas responsables y exitosas en una sociedad moderna y democrática y de que la sociedad enfrente los desafíos del presente y futuro; además, busca avanzar en el desarrollo de un marco teórico común, transversal, para la identificación de competencias clave que fundamenten una medición más precisa y apropiada de las competencias y la interpretación de los resultados empíricos (OCDE, 1999).

Otra propuesta que surgió en el ámbito internacional es el proyecto Tuning (Tuning Educational Structures in Europe), el cual surgió bajo los auspicios del Espacio Europeo de Educación Superior y que fue financiado por la Comisión Europea en el marco del programa Sócrates. El Tuning tiene como meta afinar 
las estructuras educativas de Europa abriendo un debate cuya meta es identificar e intercambiar información y mejorar la colaboración europea para el desarrollo de la calidad, efectividad y transparencia (Tuning, 2003).

Lo anterior, como parte de las propuestas creadas para el desarrollo de competencias genéricas, en el mismo ámbito internacional, pero enfocadas a las Ciencias de la Información. Es necesario mencionar la propuesta hecha por la ALA (American Library Association), que generó un documento titulado "Proffesional Competencies for Reference and Users Services Librarians", publicado en enero del 2003, el cual propone el desarrollo de las siguientes competencias: en acceso (sensibilidad, organización y diseño de servicios, pensamiento crítico y análisis), base de conocimientos (análisis del entorno, aplicación de conocimiento, difusión del conocimiento, aprendizaje activo), conocimiento de mercadotecnia de información (valoración, comunicación y difusión, evaluación), colaboración (relaciones con los usuarios, relaciones con los compañeros, relaciones dentro de la profesión, relaciones más allá de la biblioteca y de la profesión), evaluación de los recursos y los servicios de información (necesidades de los usuarios, servicios de información, recursos de información, prestación de servicios, interfaces de información, prestadores de servicios) (ALA, 2003).

Otra de las propuestas desarrolladas enfocadas a proponer las competencias que se deben desarrollar en el ámbito de las Ciencias de la Información es el proyecto titulado EuroReferencial, el cual surge con el apoyo de la Comisión Europea en el marco del programa Leonardo Da Vinci, en conjunto con la Sociedad Española de Documentación e Información Científica, propuesta que en su segunda edición ha sido elaborada por profesionales desde una perspectiva europea que integra las competencias y aptitudes que se aplican en las diferentes ocupaciones de la profesión de la información y documentación: archivero, bibliotecario documentalista, indizador documental, etcétera, las cuales han sido identificadas y comparadas. Esta propuesta está integrada por un total de treinta y tres campos de competencias divididas en cinco 
grupos, los cuales se presentan a continuación (EuroReferencial, 2004): Grupo I - Información; Grupo T - Tecnologías; Grupo C - Comunicación; Grupo G - Gestión; Grupo S - Otros saberes (SEDIC, 2004).

La propuesta más reciente en el área de las Ciencias de la Información es el Libro Blanco: título de grado en información y documentación que fue elaborado bajo los auspicios de la Agencia Nacional de Evaluación de la Calidad y de los Estudios correspondientes o afines en Europa, características de la titulación europea seleccionada, estudios de inserción laboral titulados durante el último quinquenio, perfiles y competencias profesionales. La propuesta de competencias que presenta el Libro Blanco se categoriza de la siguiente forma: 1.Interacción con los productores, los usuarios y los clientes de la información; 2. Conocimiento del entorno profesional de la información y la documentación; 3. Conocimiento del marco jurídico y administrativo nacional e internacional de la gestión de información; 4. Identificación, autentificación y evaluación de fuentes y recursos de información; 5. Gestión de colecciones y fondos; 6. Preservación, conservación y tratamiento físico de documentos; 7. Análisis y representación de la información; 8. Organización y almacenamiento de la información; 9. Búsqueda y recuperación de la información; 10. Elaboración y difusión de la información; 11. Tecnologías de la información: Informática; 12. Tecnologías de la información: Telecomunicaciones; 13. Técnicas de producción y edición; 14. Técnicas de gestión administrativa; 15.Técnicas de marketing; 16. Técnicas comerciales; 17. Técnicas de adquisición; 18. Técnicas de gestión micro-económica; 19. Técnicas de instalación, acondicionamiento y equipamiento; 20. Técnicas de planificación y gestión de proyectos; 21. Técnicas de diagnóstico y evaluación; 22. Técnicas de gestión de recursos humanos; 23. Técnicas de formación (ANECA, 2005). Estas 23 grandes competencias dan el panorama actual y vigente a nivel internacional, en relación con las competencias profesionales que conforman los perfiles de las Ciencias de la Información, y son la base que en la actualidad dan la pauta 
y enmarcan la tendencia de hacia dónde va el desarrollo de esta importante área del conocimiento.

Lo anterior se plantea como parte del contexto que permite identificar de forma clara la existencia del tema de competencias en el ámbito de la educación superior, y busca contribuir a darle fundamento a la existencia de éstas, además de que permite contar con un punto de partida que le dé sentido y significado al presente estudio ya que, según lo expresado en líneas anteriores, la literatura más reciente sobre el tema de las competencias en el área de Ciencias de la Información se encuentra plasmada de la propuesta del Libro Blanco. Los preceptos que se tomarán como base para desarrollar el estudio están plasmados en las competencias (E11 y E12) de dicho documento, las cuales mencionan de manera particular el desarrollo de competencias en el área de las tecnologías de información y comunicación, específicamente los aspectos relacionados con la informática y las telecomunicaciones; dichos tópicos sirven como marco de referencia para la elaboración del presente estudio.

\section{Propuesta PARA EL ESTUDIO}

\section{Objetivos}

a) Identificar en el mapa curricular de los programas en ciencias de la información, la carga académica / horaria en asignaturas sobre TIC.

b) Determinar la existencia de un eje / área temática / línea de formación de TIC en los planes de estudio de ciencias de la información para identificar seriación entre asignaturas.

c) Analizar los programas analíticos de las asignaturas de TIC para identificar las competencias declaradas.

d) Mostrar el estado del arte sobre las competencias tecnológicas que habrán de desarrollar los profesionales de ciencias de la información. 
e) Comparar tendencias internacionales, planes de estudio y necesidades sociales sobre el desarrollo de competencias tecnológicas en los profesionales de ciencias de la información.

f) Desarrollar propuestas para la definición o re-definición de competencias tecnológicas.

\section{Alcance}

Tipo de estudio: mixto (cualitativo-cuantitativo).

Fases de desarrollo: primera: estudio exploratorio para identificar las IES que oferten programas formales en ciencias de la información; segunda: estudio descriptivo que permita presentar el contexto general de los planes y programas de estudio por área geográfica, a partir de las competencias tecnológicas que pretende desarrollar en sus estudiantes.

Espacio / temporal: México, Latinoamérica, España; programas vigentes en 2012-2013.

Propósitos del estudio

a) Generar / definir posibles líneas / tópicos de investigación.

b) Promover el trabajo colaborativo desde un enfoque interdisciplinar y/o transdisciplinar.

c) Generar propuestas para definir o re-definir las competencias tecnológicas para los programas formales en ciencias de la información a nivel local, regional, nacional o internacional.

Plan general de trabajo

Análisis de Planes de Estudio: Región México

a) Universidad Autónoma de San Luis Potosí

b) Universidad Nacional Autónoma de México 
c) Escuela Nacional de Biblioteconomía y Archivonomía

d) Universidad Autónoma de Chihuahua

e) Universidad Autónoma de Chiapas

f) Universidad Autónoma del Estado de México

g) Universidad de Guadalajara

Tópicos
a) Mapa curricular
b) Ejes / áreas temáticas / líneas de formación
c) Seriación
d) Competencias

Análisis del eje de las TIC
a) Asignaturas
b) Carga académica / horaria
c) Programas de estudio
d) Contenidos temáticos

Análisis del perfil del docente del eje de las TIC

a) Formación académica

b) Asignaturas que imparte

Estudio comparativo de las competencias tecnológicas en los programas en ciencias de la información en México

a) Integración y evaluación de resultados

b) Generación de conclusiones

c) Revisión del estado del arte sobre las competencias tecnológicas en los profesionales de ciencias de la información. 
Agendas de Investigación en Bibliotecología...

Análisis de Planes de Estudio: Región Latinoamérica

a) Determinar países

b) Identificar universidades

c) Mapa curricular

d) Ejes / áreas temáticas / líneas de formación

e) Seriación

f) Competencias

Análisis del eje de las TIC

a) Asignaturas

b) Carga académica / horaria

c) Programas de estudio

d) Contenidos temáticos

Análisis del perfil del docente del eje de las TIC

a) Formación académica

b) Asignaturas que imparte

Estudio comparativo de las competencias tecnológicas en los programas en ciencias de la información en Latinoamérica

a) Integración y evaluación de resultados

b) Generación de conclusiones

Estudio comparativo de las competencias tecnológicas en los programas en ciencias de la información en Latinoamérica

a) Análisis de Planes de Estudio: Región España.

b) Determinar estados

c) Identificar universidades 
d) Mapa curricular

e) Ejes / áreas temáticas / líneas de formación

f) Seriación

g) Competencias

Análisis del eje de las TIC
a) Asignaturas
b) Carga académica / horaria
c) Programas de estudio
d) Contenidos temáticos

Análisis del perfil del docente del eje de las TIC
a) Formación académica
b) Asignaturas que imparte

Estudio comparativo de las competencias tecnológicas en los programas en ciencias de la información en España
a) Integración y evaluación de resultados
b) Generación de conclusiones

Integración de resultados
a) Presentación de propuestas
b) Conclusiones 
Agendas de Investigación en Bibliotecología...

\section{CRONOGRAMA}

\begin{tabular}{|c|c|c|c|c|c|c|c|c|c|c|c|c|}
\hline Año & \multicolumn{2}{|c|}{2012} & \multicolumn{9}{|c|}{2013} \\
\hline Etapa & Nov. & Dic. & Ene. & Feb. & Mar. & Abr. & May. & Jun. & Jul. & Ago. & Sep. & Oct. \\
\hline A & & & & & & & & & & & & \\
\hline B & & & & & & & & & & & & \\
\hline C & & & & & & & & & & & & \\
\hline D & & & & & & & & & & & & \\
\hline
\end{tabular}

\section{CONSIDERACIONES FINALES}

La presente propuesta de trabajo representa una oportunidad de establecer o reforzar lazos institucionales y personales, a fin de desarrollar de manera colaborativa una serie de estudios relacionados con las competencias tecnológicas que habrán de formar parte de los planes y programas de estudio que se ofertan de manera formal a nivel licenciatura en México, Latinoamérica y España.

Por otro lado, es conveniente señalar que, como parte de la estimación del éxito de esta investigación, debemos tomar en cuenta que habrá de ser atendida desde un enfoque interdisciplinar y con una perspectiva transdisciplinar, de tal forma que los resultados que se obtengan sean lo más objetivos posibles y apegados a la realidad, según el contexto específico de donde éstos se deriven.

Finalmente, cabe mencionar que se han iniciado los trabajos para llevar a cabo el estudio correspondiente a México, y que se ha establecido un primer contacto con quienes pueden colaborar para el estudio de la región de España, es decir, que la Universidad Autónoma de San Luis Potosí y la Universidad Complutense de Madrid han manifestado interés para conformar un equipo de trabajo que atienda esta propuesta; se espera que en breve se sumen también representantes de las universidades de América Latina. 
Perspectivas de análisis de las competencias tecnológicas...

\section{REFERENCIAS BIBLIOGRÁFICAS}

American Library Association (2003), Professional competencies for reference and user services librarians, USA, ALA.

Agencia Nacional de Evaluación de la Calidad y Acreditación (2005), Libro Blanco: Título de grado en información y documentación, España, ANECA.

Centro Nacional de Evaluación (2005), Boletín CENEVAL, Junio 2005, Núm. 14, México.

Cox, R. (1997), “A perspective on globalization”, en Globalización: critical reflections. Boulder, London: Lynne Reinner Publishers, pp. 21-30.

Elliot, J. (1991), Action research for educational change, Bristol, P. A.: Open University Press.

Mittelman, J. (1997), "The dynamics of globalization", en Globalization critical reflections London: Lyme Reinner Publishers, pp. 1-19.

Montero, A. (1996), El mundo desigual: ensayos frente al neoliberalismo, San José, Costa Rica, EunED.

Morin, E. (1999), Los 7 saberes necesarios para la educación del futuro, Francia, UNESCO.

Organización Internacional del Trabajo (2004), Recomendación 195: desarrollo de los recursos humanos, educación, formación y aprendizaje permanente, OIT. 
Agendas de Investigación en Bibliotecología...

Organización para la Cooperación y el Desarrollo Económicos (1999), Proyectos sobre competencias en el contexto de la OCDE: Análisis de base teórica y conceptual, OCDE.

Sociedad Española de Información y Documentación Científica (2004), Euroreferencial en información y documentación: competencias y aptitudes de los profesionales europeos de información y documentación, Vol. 1, Madrid, SEDIC.

Tremblay, G. Pedagogía colegial (1994), disponible en: http://www. gestiopolis.com/ recursos2/documentos/fulldocs/rrhh/controcomplab.htm.

Universidad de Deusto (2003), Tuning Educational Structures in Europe: Informe final fase uno, España, UD.

Zavala, A. y Arnau, L. (2007), 11 ideas clave: cómo aprender y enseñar competencias, Barcelona, Graó. 


\section{La investigación sociológica de la ciencia. Una experiencia de trabajo de campo y consulta de archivos sobre el desarrollo de la astronomía en México}

JORGE BARTOLUCCI

Universidad Nacional Autónoma de México

\section{EL PROBLEMA}

gradezco al doctor Ríos la invitación a participar en este
coloquio para hablarles de mi experiencia de investiga-
ción en el campo de la sociología de la ciencia, en particular sobre el surgimiento y evolución de la astronomía moderna en nuestro país. Lo primero que he de referir en ese sentido son las circunstancias bajo la cuales decidí llevar a cabo ese proyecto, ciertamente fortuitas. En mayo de 1990, la Universidad Nacional Autónoma de México organizó un Congreso Universitario con el propósito de exponer al examen crítico de su comunidad diversos aspectos de su vida académica e institucional, en el cual participé como asesor de uno de los funcionarios universitarios que integraban la Mesa Temática: Formación Académica y Profesiones.

Entonces andaba en busca de un tema de investigación para iniciar un nuevo estudio en el área de sociología de la educación superior en México. En vista de la privilegiada posición en que me encontraba como observador no participante, decidí no dejar pasar la oportunidad y me dispuse a tomar nota de todas 
las expresiones verbales que los delegados vertieron durante los días que duró el evento, a reunir los documentos presentados al pleno y a realizar algunas entrevistas entre los participantes. La pregunta que inicialmente orientó mi pesquisa fue si habría alguna relación significativa entre las posiciones sustentadas en el Congreso y su experiencia profesional en sus respectivos campos de conocimiento y entidades universitarias. Por consiguiente, la primera parte del interrogatorio que les hice iba dirigida a explorar las circunstancias bajo las cuales habían pasado a formar parte de los mismos. La segunda, trataba de captar aspectos relevantes de la estructura social de las disciplinas científicas y de la vida académica dentro del grupo, y la tercera versaba sobre las posiciones sostenidas en el Congreso.

Entre los entrevistados se encontraba uno de los delegados que representaban al Instituto de Astronomía (IA). Conforme el esquema previsto, la conversación que mantuve con él inició preguntándole sobre las condiciones bajo las cuales había llegado a convertirse en astrónomo así como en las características particulares de su formación y desarrollo profesional. Proseguimos platicando acerca de su interacción académica en el medio astronómico local e internacional y, por último, le pedí que se expresara acerca de las posiciones asumidas en torno a la discusión sobre la formación académica y profesional en la UNAM, tema de la mesa correspondiente.

Las referencias brindadas sobre el proceso de desarrollo de la astronomía en México cautivaron mi curiosidad sociológica, y sentí que la motivación que me había llevado hasta allí podría tomar un rumbo insospechado; la información recabada sobre las partes del cuestionario relativas a su inserción en esa particular disciplina científica y a su experiencia académica pasó a ser mucho más interesante que la concerniente a las posiciones adoptadas en el Congreso. Eso me llevó a aceptar gustoso su invitación a entrevistar a los otros dos investigadores del iA que habían participado en el evento, quienes a su vez me sugirieron incluir nuevos colegas en el sondeo. 
Conforme avanzaba en las entrevistas, noté que independientemente de los factores que habían influido en la decisión de convertirse en astrónomos y de las trayectorias seguidas por la formación académica y el ejercicio profesional, casi todos los encuestados se referían a la problemática astronómica local en términos de lo que ésta había sido "antes" y lo que era "ahora", y de lo diferentes que eran las cosas "aquí y allá”. Respecto del primer binomio (antes-ahora), ya fuese debido a experiencias personales o a ideas circulantes en el medio, en alguna medida casi todos subrayaban el tránsito de la astronomía mexicana de una situación anterior calificada como "antigua" a otra llamada "moderna". Aquí caben las múltiples referencias a la astronomía de posiciones y la astrofísica, a los nombres de Raúl Anguiano, Joaquín Gallo, Luis Enrique Erro y Guillermo Haro, a la creación del Observatorio de Tacubaya, a la epopeya de la cámara Schmidt y a la construcción del Observatorio de San Pedro Mártir.

En cuanto al segundo binomio (aquí-allá), tanto la problemática profesional individual como la de la comunidad en general eran visualizadas en torno a la oposición entre lo que aconteció o acontece en los grandes centros científicos mundiales y lo que sucedió o sucede en México. De ello hablaban las experiencias vividas en el extranjero, los lugares donde fueron a estudiar, las especialidades elegidas, sus asesores, los vínculos con la comunidad internacional, los recursos técnicos disponibles, sus carencias, aspiraciones profesionales y proyectos individuales o compartidos.

La forma en que la realidad astronómica era representada por el grupo me llevó a pensar que el estudio exhaustivo de este caso serviría para contribuir al conocimiento del proceso de desarrollo de la ciencia en México y de su integración plena a la comunidad internacional. Con esta idea en mente entrevisté a casi todos los investigadores y técnicos académicos del IA, asistí a sus reuniones colegiadas y académicas, visité los observatorios de Tonantzintla y San Pedro Mártir y le di seguimiento a uno de los proyectos de instrumentación tecnológica más importantes en aquel tiempo. Valga comentar que mi presencia en el Instituto de 
Astronomía durante los dos años que duró el trabajo de campo, lejos de provocar resistencias o crear malestares, se volvió tan familiar que algunos bromeaban diciéndome que acabaría dejando la sociología por la astronomía.

El paso siguiente fue localizar fuentes documentales que sirvieran para darle más cuerpo a la información recabada por la vía observacional. En ese entonces no se le había prestado demasiada importancia a la conservación de documentos históricos, y sólo se habían preservado algunos instrumentos, fotos y documentos, por iniciativa personal de uno que otro astrónomo. Como paliativo, me puse en contacto con familiares de los personajes protagónicos de la historia para acceder a los archivos personales que supuestamente habían heredado, ninguno de los cuales prosperó. Por fortuna, en una de las tantas pláticas que sostuve a lo largo de la investigación con uno de los astrónomos de mayor antigüedad en la comunidad en aquel momento, ${ }^{1}$ mencionó que frente a la "casita de París Pismis", ${ }^{2}$ había una habitación llena de cajas.

Así fue como accidentalmente, en 1992, fui a dar a una bodega en las instalaciones que el Instituto de Astronomía posee en el Observatorio de Tonantzintla, en Cholula, estado de Puebla, donde efectivamente se hallaban apiladas un buen número de cajas de cartón repletas de documentos. Sólo algunas se encontraban cerradas y en buen estado, la mayoría estaban abiertas con los papeles desparramados por el suelo. Inmediatamente me puse a revisar el contenido de una en una, y, aunque somera, la exploración fue suficiente para darme cuenta que se trataba de una serie bastante completa de documentos oficiales referentes a la astronomía mexicana practicada en México entre 1860 y 1970, aproximadamente.

Increíble, ¡había dado con un archivo virgen! De ahí en más me avoqué a hacer un exhaustivo reconocimiento del material. Previendo un viaje al extranjero que estaba programado a partir de octubre de 1992, para realizar una estancia académica de un

1 Enrique Chavira.

2 Nombre del lugar donde la célebre astrónoma se alojaba durante sus largas temporadas de observación. 
año en dos universidades norteamericanas, resolví fotocopiar el material seleccionado para llevarlo conmigo. Entre octubre de 1992 y marzo de 1993 estuve colaborando en el Centro de Estudios Latinoamericanos de la Universidad de Chicago, invitado por el doctor Friedrich Katz en calidad de Visiting Scholar. Ese semestre lo dediqué a estudiar la historia de la astronomía estadounidense y a contrastar dicho proceso con el que había seguido el establecimiento de la astronomía moderna en nuestro país.

A finales de marzo recibí una invitación similar del doctor Owen Gingerich para ocupar el mismo cargo en el Departamento de Historia de la Ciencia, del Science Center de la Universidad de Harvard, hasta noviembre de ese mismo año. En ese periodo me dediqué a revisar una colección de documentos valiosísimos guardada en los archivos de dicha universidad, sobre el proceso que condujo a la fundación del Observatorio Astrofísico de Tonantzintla a principios de 1942 y a lo acontecido allí hasta 1950. En 1997, regresé al Science Center para revisar la información correspondiente a la década siguiente.

En forma simultánea gestioné ante la dirección del Instituto de Astronomía la donación de la documentación encontrada, al Archivo Histórico de la UnAM (AHUNAM) ${ }^{3}$ con el compromiso de someterla a los procesos de limpieza, restauración y resguardo que el AHUNAM acostumbra. Vale mencionar que el estado en que se encontraba el archivo en la bodega no permitía identificar el orden o la organización que pudo haber tenido originalmente. De modo que el único orden visible fue el que le dieron los encargados de transportarlo de la bodega al archivo. El nuevo fondo documental ingresó al AHUNAM el 2 de julio de 1992 con el nombre de Fondo Observatorio Astronómico Nacional (FOAN) y, una vez cumplidos los pasos de limpieza y desinfección del material, se procedió a realizar una revisión completa del contenido de las cajas.

En el año 2000 la documentación quedó resguardada en 425 cajas que contenían 1956 expedientes manteniéndose el orden

3 El AHunam era parte del Centro de Estudios sobre la Universidad, hoy Instituto de Investigaciones sobre la Universidad y la Educación. 
que tenían en ese momento. Como resultado de una subsecuente revisión, en 2006 se completó la Guía del Fondo Observatorio Astronómico Nacional, instrumento que contenía una descripción general del contenido de cada documento y su ubicación en la caja y el expediente correspondiente. ${ }^{4}$ Actualmente, gracias al apoyo otorgado por la Dirección General de Asuntos del Personal Académico de la UNAM al proyecto PAPIIT: El Observatorio Astronómico Nacional: De Tacubaya a San Pedro Mártir, el contenido del FOAN está completamente clasificado en orden cronológico de acuerdo con los criterios establecidos en un cuadro de clasificación elaborado bajo criterios fijados con base en la experiencia de investigación. 5

Para dar una idea de lo que implicó el establecimiento de la astronomía moderna en México, diré que el primer intento de erigir un observatorio nacional que promoviese el progreso de la ciencia astronómica data de 1842. Éste no prosperó y le siguieron otros que tampoco llegaron a buen término. Con la fundación del Observatorio Astronómico Nacional en 1878, las condiciones para hacer estudios astronómicos mejoraron y durante treinta años fue operado normalmente por gente muy tenaz en su trabajo, bien informada en la materia y con vínculos estrechos con la comunidad internacional. A partir de 1910, la lucha por el poder que sucedió al pronunciamiento revolucionario creó condiciones muy desfavorables a la investigación, y los recursos humanos, financieros y técnicos del Observatorio se redujeron considerablemente.

Esto cambió a finales de la década de los treinta, cuando el sistema político logró establecer cauces institucionales a la sucesión presidencial, años en los cuales se inició el proceso de construcción del Observatorio Astrofísico de Tonantzintla, inaugurado en el invierno de 1942, el cual sentó las bases para el establecimiento de la astrofísica moderna en México. La construcción de este observatorio fue posible gracias a la solidaridad del director

4 Documento preparado por el Técnico Académico del AHUNAM, Mariano Mercado.

5 Susana Biro, Jorge Bartolucci, El Fondo Observatorio Astronómico Nacional, XXII Congreso Nacional de Astronomía, México, abril 2008. 
del Observatorio de la Universidad de Harvard, Harlow Shapley, y al apoyo incondicional del gobierno de México a un grupo de jóvenes científicos mexicanos, encabezado por Luis Enrique Erro, en medio de una situación interna muy particular de la política mexicana y de los problemas geopolíticos planteados por la Segunda Guerra Mundial.

La posterior obra de Guillermo Haro junto con la presencia de la Universidad Nacional en la escena de la astronomía mexicana y la influencia del Harvard College Observatory en la posguerra, coadyuvaron a generar las condiciones necesarias para que, a partir de los años cincuenta, la astronomía mexicana se integrara plenamente al mundo de la ciencia moderna y se convirtiera, de una vez por todas, en una profesión viable en nuestro país. La investigación que realicé es un intento por reconstruir aquella historia desde la perspectiva sociológica que presentaré a continuación.

\section{EL ENFOQUE TEÓRICO}

A manera de introducción, relataré un par de anécdotas extraídas de mi prolongada incursión en el mundo de los astrónomos. En una ocasión en la cual me disponía a levantar una nueva entrevista, el entrevistado me confesó que mi forma de trabajar le había hecho ver que la sociología era una disciplina más seria de lo que suponía. Y agregó: "Yo siempre creí que los sociólogos sacaban las cosas de su cabeza, pero al verte trabajar a ti, me doy cuenta que al igual que nosotros tu te apoyas en observaciones muy sistemáticas”.

Otra vez, en una de las jornadas de la Primera Escuela de Astrofísica celebrada en México a principios de 1993, le pedí a su organizador que me permitiera distribuir un cuestionario entre los asistentes. Él asintió de buen agrado y me presentó ante los concurrentes como un sociólogo que estaba haciendo una investigación sobre los astrónomos mexicanos. Con la intención de predisponer favorablemente al auditorio y hacer que sus colegas colaboraran con mi investigación, señalando con el puntero ha- 
cia un dibujo que había hecho en el rotafolio, concluyó con la siguiente frase: "Nosotros observamos las estrellas, y Jorge nos observa a nosotros".

La simpática comparación hizo que la gente riera; sin embargo, se apuntaba a algo más serio de lo que resulta a simple vista. De hecho, la astronomía y la sociología se asemejan bastante. Ambas son ciencias observacionales, ciencias de realidad, como diría Max Weber; sólo pueden recabar información de sucesos no reproducibles por la vía experimental. Sus procedimientos analíticos también se parecen. Al serles negada la posibilidad de experimentar con los hechos que estudian, no les ha quedado más remedio que hacer lo posible por recrearlos analíticamente, lo cual equivale a algo así como a experimentar con la mente, poniendo bajo consideración todas las conexiones que en las circunstancias recreadas resulten objetivamente posibles. El astrónomo observa un fenómeno celeste y para explicar por qué el fenómeno es de esa y no de otra manera, recurre a una idea, o sea, crea un modelo perfecto de acuerdo con las leyes de la física y apoyado en las matemáticas, que le permite anticipar la clase de información que cabe esperar recibir según las condiciones planteadas por el mismo. En caso de no recibir la información esperada, se pone a conjeturar sobre los factores físicos y químicos que estarán influyendo en las variaciones observadas. ${ }^{6}$

Al observar los hechos sociales, los sociólogos también recurrimos al mismo tipo de construcciones conceptuales, a los

6 Otra cosa en común entre la sociología y la astronomía es el alto grado de incertidumbre con que éstas trabajan. Sus objetos son lejanos, inasibles; la información que ofrecen son indicios, señales bastante débiles y confusas de una realidad jamás alcanzable. Hasta que conocí a los astrónomos, siempre me sentí incómodo ante esa discriminatoria distinción entre las ciencias duras y las blandas. Después de esta experiencia quedé convencido de que la dureza de las ciencias naturales reside más en su orden interno que en el conocimiento mismo. Gracias a ese orden interno, están muy claro los límites entre lo que se sabe y lo que no se sabe, lo que es un razonamiento fundamentado y lo que es una tontería, el que sabe de lo que está hablando y el que no sabe, entre avanzar en el conocimiento empírico a pesar de las dudas epistemológicas que existen y pretender resolver en la cabeza los problemas filosóficos que encierra la ciencia. 
cuales llamamos "típico ideales", donde se reúnen determinados hechos, procesos y relaciones de la realidad histórica en un cosmos social, que como los modelos de la física y las matemáticas son carentes en sí de contradicciones. Pero entre la observación de los hechos naturales y la sociológica hay una diferencia insalvable. Los hechos, datos y sucesos que aborda el astrónomo o el físico, sólo son significativos dentro del ámbito de la física y de las matemáticas, no significan nada para los cuerpos que estudia. El mundo de la naturaleza no significa nada para las moléculas, átomos y electrones que hay en él; los astros no tienen una interpretación de sí mismos ni del lugar que ocupan dentro de una galaxia o del cosmos, como tampoco la tienen de su órbita o de su origen y evolución. Dichas posiciones no asumen ningún valor para ellos ni establecen relaciones de cooperación o conflicto con el objeto de modificarlas. Quiere decir que los hechos naturales son significativos solamente desde un punto de vista astronómico, no revelan estructuras intrínsecas de significatividad. ${ }^{7}$

En cambio, los seres humanos somos la única especie del universo conocido capaz de dotar de valor y significado a las cosas, a las ideas e inclusive a otros hombres. En virtud de este peculiar atributo, los hombres creamos todo tipo de representaciones, que son al mismo tiempo conocimientos y referentes para orientar nuestro comportamiento en sociedad. Las creencias, doctrinas, ideologías, mitos, justificaciones, idealizaciones, explicaciones y teorías establecidas o reproducidas por el hombre, y mediante las cuales nos representamos y significamos la realidad, suman en conjunto nuestro conocimiento del mundo y dicho saber nos sirve tanto para constituirlo como un mundo coherente y significativo como para orientarnos en él.

Dichas representaciones pueden asumir formas rudimentarias, como las opiniones e ideas que expresamos vulgarmente, o formas más elaboradas, como los mitos, las ideologías, las religiones y aun la ciencia misma. La perspectiva sociológica que aquí se muestra atiende precisamente a la relación de este saber con

7 Alfred Schutz, El problema de la realidad social, Amorrortu Editores, Buenos Aires, 1974, p. 37. 
procesos sociales concretos; cuestión que está presente en investigaciones sobre cualquier medio social, pero que es particularmente importante cuando se trata de estudiar hechos que tienen que ver con círculos intelectuales e instituciones donde se crea y reproduce el conocimiento científico. En este caso, el diafragma observacional se cierra y la curiosidad sociológica concentra su atención en responder preguntas tales como: ¿qué lugar ocupa el conocimiento científico en una época y en una sociedad determinada?, ¿quiénes enarbolan dichos intereses?, ¿cómo los representan, justifican, explican o idealizan?, ¿qué clase de saber privilegian?, ¿qué vínculos establecen con su comunidad dentro y fuera del país que habitan? ¿qué tipo de conexiones mantienen con otras esferas de la vida social?

\section{EL MÉTODO}

El enfoque teórico esbozado induce a seguir el camino de la investigación cualitativa, que no es, como vulgarmente se piensa, un conjunto de procedimientos para obtener datos que se define en oposición a lo cuantitativo. Es un modo específico de encarar la observación del mundo empírico que tiene la virtud de extraer las tonalidades cualitativas del dato aun usando fuentes cuantitativas. Lo determinante no es el tipo de fuentes en las que nos basamos, sino el hecho de trazar una estrategia analítica que nos permita observar a los seres humanos como organismos vivos y a la acción como una conducta construida por individuos en interacción. Se trata de captar el papel del actor y ver el mundo desde su punto de vista, comprendiendo el modo como ellos perciben e interpretan su propia situación así como las consecuencias que se derivan de la conducta seguida.

Al revivir la situación observada desde la perspectiva de los actores involucrados en un hecho social, se supone que los mismos son individuos integrales que se ven obligados a manipular y administrar una realidad personal compleja, persiguiendo fi- 
nes determinados y manipulando ciertos recursos y marcos de referencia acordes con sus intereses y percepciones particulares forjados en su experiencia de vida. Frente a lo cual lo más importante, analíticamente hablando, es captar el significado que los participantes le otorgan a la parte de sus vidas que cae dentro del tema de nuestro estudio, y entender el sentido que tiene para ellos en el contexto de las relaciones que mantiene con su sociedad en un momento determinado.

El sistema prevaleciente de intereses determina la naturaleza de tal selección. Sea como fuere, existe una selección de cosas y aspectos de las cosas que son significativos para las personas en un momento dado, mientras que otras no revisten interés o están fuera de su alcance o perspectiva. Ambas posibilidades asumen diferentes grados de importancia, porque toda elaboración de un proyecto se basa en el supuesto de que toda acción que suceda dentro del sector del mundo bajo mi control real o potencial sería practicable. Los elementos mencionados son tan útiles para entender la situación bajo la cual las personas consideran que la acción proyectada es factible, como para entender, en parte, el efecto de sus resultados. Especialmente en una investigación como ésta, interesada en una experiencia de modernización científica, en la cual el primer plano de la escena lo ocupan quienes habían liderado proyectos de cambio.

Empíricamente, el estudio consistió en relacionar algunos momentos clave del proceso de modernización de la astronomía mexicana con la conducta de algunos personajes también clave, involucrados directa o indirectamente en la definición de las condiciones de concreción del mismo. La idea central fue demostrar hasta qué punto la modernización de la astronomía mexicana se explica a la luz de algunos datos de experiencia de dichos personajes y cuáles son los matices particulares que adoptó en virtud de ello. La hipótesis subyacente es que el grado de incidencia en la evolución de la astronomía mexicana tuvo bastante que ver con las interpretaciones que ellos mismos construyeron acerca de las condiciones culturales, políticas, sociales, intelectuales y económicas que los afectaban. 
La manera como sus atributos personales, valores morales, horizontes intelectuales y posiciones en la sociedad y la política se hicieron presentes en dicha participación, ofrecieron respuestas muy reveladoras a lo largo de la investigación. En ese sentido, su aportación al proceso de modernización pudo ser interpretada como una respuesta adecuada a las ideas que motivaron su proyecto, las que a su vez estuvieron significativamente relacionadas con las determinaciones de su biografía social, y con las posibilidades y limitaciones que ellos percibieron como parte consustancial de su tiempo y de la realidad inmediata. A manera de ejemplo, me detendré brevemente en uno de los pasajes de esa historia.

\section{EL CASO}

Al final de la presidencia de Lázaro Cárdenas (1934-1940), Luis E. Erro, un político mexicano y aficionado al estudio de las estrellas variables, lideró un proyecto que condujo a la astronomía de su país hacia el encuentro con la astrofísica moderna. Antes de dejar el poder, el general Cárdenas le preguntó a Luis Enrique qué era lo que quería para él en recompensa a su lealtad y a los servicios prestados a la Revolución Mexicana. Erro respondió: "un Observatorio nacional para México”. Cárdenas estuvo de acuerdo, pero le preguntó a Erro cómo iba a operar un observatorio moderno en un país sin expertos y donde existía únicamente "[...] el adormilado Observatorio de Tacubaya, dirigido por Joaquín Gallo”. Erro le contestó que él tenía muy buenos amigos en el Harvard College Observatory, donde por intermedio de Leon Campbell había llegado a conocer personalmente al gran Harlow Shapley. ${ }^{8}$ El 18 de diciembre, Enrique Erro le escribió a Shapley comunicándole que "[...] su Gobierno había decidido construir un nuevo Observatorio Astronómico en México”, y enfatizó “que ellos iban a demostrarle a la Vieja Guardia en México, qué era lo

8 Bart Bok, Astronomia Mexicana, 1930-1950; Marco A. Moreno C. Historia de la Astronomía en Mexico. 
que se podía lograr cuando uno tiene buenos amigos y el espíritu adecuado".?

Shapley respondió inmediatamente, haciéndole saber a Erro que él apreciaba mucho que lo mantuviera informado acerca de toda la situación imperante en México respecto del medio astronómico, y que a su entender era mucho lo que se podía hacer contando con un presupuesto de 20, 000.00 dólares. ${ }^{10}$ La inauguración del nuevo Observatorio Astrofísico de Tonantzintla fue el 17 de febrero de 1942. Muchos de los astrónomos más reconocidos de entonces asistieron al evento, invitados personalmente por Shapley a solicitud expresa de la Embajada Mexicana en Estados Unidos. El principal instrumento del nuevo observatorio era un telescopio reflector de 27-31 pulgadas diseñado por Schmidt y construido en un tiempo muy corto en los talleres de óptica de la Universidad de Harvard. ${ }^{11}$

Ante lo cual cabe preguntarse: ¿cómo fue posible construir semejante telescopio para México en un momento donde el único observatorio existente no tenía recursos suficientes ni para mantener a su escaso personal? Para comenzar, hizo falta que se juntaran en una misma persona la afición por la astronomía y la influencia política. Cosa que había ocurrido en el pasado, sólo que en esta oportunidad, el talante revolucionario de Luis E. Erro le dio al proyecto una fuerza inusitada. Además, la coyuntura política nacional e internacional a principio de los cuarenta resultó ser muy favorable para que la empresa modernizadora prosperara.

Por un lado, la lucha por el poder en México después del gobierno cardenista derivó en políticas gubernamentales tendientes a ganarse la amistad del gobierno estadounidense. Por otro lado, las necesidades geopolíticas de la Segunda Guerra Mundial moti-

9 L. E. Erro to H. Shapley, Dec, 1940, Harvard University Archives, Pusey Library, Harvard College Observatory, UA V 630. 22. 5, Box 1, Mexican Conference 1939-1942.

10 L. E. Erro a H. Shapley, February 21, 1939, Harvard University Archives, Pusey Library, Harvard College Observatory, UA V 630. 22. 5 Box 1, Mexican Conference 1939-1942.

11 Bart Bok, Astronomia Mexicana, 1930-1950; Marco A. Moreno C. Historia de la Astronomía en Mexico. 
varon que la política exterior norteamericana hacia América Latina en general y con respecto a México en particular, se orientara en el mismo sentido. Como consecuencia de esa alianza política, la construcción del Observatorio Astrofísico de Tonantzintla adquirió un valor no sólo científico, sino también político.

A las condiciones geopolíticas y al talante revolucionario de Erro, se sumó la claridad intelectual que él y sus colaboradores más cercanos tenían respecto a dónde se encontraba en esos momentos la vanguardia de la investigación astronómica, que se localizaba en los Estados Unidos y no en Europa, como lo sostenía Joaquín Gallo, férreo opositor al proyecto. Su gestión en ese sentido contó con la amistad, asesoramiento y apoyo incondicional de Harlow Shapley, director del Harvard College Observatory, quien después de una efectiva labor académica se había empeñado en una cruzada política de apoyo a la ciencia universal en general y a la astronomía en particular.

Entre sus obras más importantes en ese sentido, destaca su participación en la creación de fundaciones norteamericanas de apoyo financiero a la ciencia local y la ayuda prestada a instituciones y astrónomos extranjeros. La guerra reforzó sus ideales pacifistas y universalistas. Su apoyo decidido al proyecto mexicano se inscribió exactamente en ese espíritu. Al mismo tiempo, las circunstancias lo llevaron a involucrarse en el proyecto bélico más importante del Harvard College Observatory durante la Segunda Guerra Mundial. Merced al compromiso moral de Shapley con el proyecto de Erro, a su posición como investigador principal en los Talleres Ópticos de Harvard y al interés gubernamental norteamericano de estrechar lazos con México, nuestro país se hizo de uno de los instrumentos de observación astronómica más poderosos de la época con una mínima inversión.

En el marco trazado por una situación política favorable y una visión intelectual correcta, la mancuerna Erro-Shapley logró que el apoyo financiero y político brindado por el Estado mexicano a la ciencia fuese empleado por primera vez en la historia de la astronomía local, en un proyecto científico con futuro. Si Tonantzintla representó el parteaguas entre la antigua astronomía de 
posiciones y la astrofísica moderna, no es sólo porque técnicamente haya sido un observatorio de avanzada, sino y sobre todo porque su construcción significó agrupar y poner en movimiento las fuerzas políticas, sociales e intelectuales que ante las circunstancias históricas que atravesaba el país y el mundo resultaban ser las más adecuadas a ese fin.

\section{CONCLUSIÓN}

Por razones de tiempo no es posible detenernos en los detalles de este proceso. Su inclusión en un libro colectivo como éste, sólo se justifica en la medida que ofrece un ejemplo del provecho que puede derivarse del uso de las diversas fuentes de información recabadas en una agenda de investigación sociológica centrada en el desarrollo de la ciencia en México. Conforme al enfoque teórico adoptado, el proceso de desarrollo de la astronomía en México fue considerado como una realidad emergente del entrecruzamiento de acciones intencionales llevadas a cabo bajo circunstancias históricas que fueron registradas, interpretadas y representadas desde perspectivas diferentes. Mediante el análisis de los testimonios extraídos de las entrevistas, la observación de campo y la documentación de archivo, con el apoyo de la bibliografía general y específica consultada, fue posible reconstruir el sentido adherido a la participación de los sujetos involucrados en la historia. Al configurar la situación analizada mediante el entrecruzamiento de las líneas trazadas desde los diferentes puntos de vista implicados en la trama se obtuvo una imagen mucho más compleja del objeto de estudio, apuntalando el propósito de captar la historia haciéndose.

A fin de contar con referentes que permitieran establecer relaciones entre el tiempo corto y el largo, entre el acontecimiento y la estructura, la información obtenida por vía documental o directa fue contextualizada, en el marco de procesos sociales, políticos y económicos de mayor alcance y duración. Al hablar 
de contexto no me refiero al recurso tan arraigado en los medios académicos de introducir una dimensión superior de la realidad social como mero antecedente histórico del problema de investigación, o bien, para tender un telón de fondo fijo con la única intención de darle ubicuidad al movimiento de los hechos y personajes más cercanos. Me refiero al hecho de haber encontrado los lazos que integraban a los protagonistas de mi objeto de estudio con los niveles más amplios del mundo de vida al cual se hallaban ligados significativamente. Pienso que un hecho social es parte del contexto de la misma manera que un pasaje literario es parte indisoluble del argumento de la obra. Hecho y contexto, al igual que otras antinomias como individuo y sociedad, interno y externo, centro y periferia, son partes constitutivas de un mismo tejido social elaborado con base en la interacción significativa de los participantes a diferentes niveles de la vida social.

En términos operativos, esta premisa teórica nos obliga a cumplir con el mandato de no aislar al actor de la sociedad ni del proceso social en el que participa, y a buscar la racionalidad de su acción en el medio social dentro del cual transcurren sus experiencias. La trama resultante de este procedimiento analítico es la única vía idónea que faculta al investigador a escalar dimensiones histórico-sociales superiores en procura de una reconstrucción más compleja de su objeto de estudio. Para quienes nos dedicamos a la investigación sociológica, esta perspectiva teórica es particularmente indicada. No sólo por ser la vía más idónea para llegar aumentar nuestro conocimiento sobre las bases sociales que sostienen a nuestros objetos de estudio, sino también para justipreciar debidamente las posibilidades reales de cambio. Difícilmente podremos darle una solución efectiva a los problemas que motivan nuestro interés si no alcanzamos a conocer la estructura social que los sostiene y a identificar los patrones de acción que reproducen sistemáticamente. 


\title{
Las competencias en los planes de estudio de Ciencias de la Información: análisis de escenarios
}

\author{
ROSA MARÍA MARTÍNEZ RIDER \\ Universidad Autónoma de San Luis Potosí, México
}

\section{CONSIDERACIONES SOBRE EL CURRÍCULUM}

$\mathrm{E}$

1 mundo atraviesa por grandes cambios y México no es la excepción: los esquemas de la educación superior se han modificado, pues "en el descuidado campo educativo no existía un modelo de reforma que involucrara los procesos de globalización y regionalización del mundo". ${ }^{1}$ Enrique Luengo ${ }^{2}$ destaca que en la década de los setenta se dio un crecimiento no previsto, en el que se ponderaron los aspectos cuantitativos.

Expresa que, sin considerar la calidad de resultados, el sistema creció sin regulación, o bien, se iniciaron las estrategias de planeación articulando los planes de desarrollo con el financiamiento público de las instituciones de educación superior.

Se reconoce que la sociedad mexicana tiene un contexto de crisis recurrentes con paradojas y contradicciones, pero aunque se plantea que "En la era del conocimiento, la educación no cum-

1 A. Marín Marín, "La globalización y su impacto en la reforma universitaria mexicana" [en línea].

2 E. Luengo González, "Tendencias de la educación superior en México" [en línea]. 
ple solo un papel estratégico. Amplía sus fronteras a la configuración de un modelo de sociedad que proporcione bienestar a sus habitantes; disminuya las brechas entre regiones y grupos sociales; impulse la democracia como forma de vida en todos los campos de acción humana; promueva la tolerancia y el respeto para la convivencia social", ${ }^{3}$ la realidad es que se centra en las necesidades de la economía abierta, porque destaca la vinculación con el sector productivo como factor preponderante para el crecimiento de las universidades públicas.

Las acciones derivadas de la crisis, en particular la económica y la social, han tenido distintos productos y resultados en el tema internacional. Sin embargo, han sido una guía normativa importante para ordenar, sistematizar y justificar los presupuestos en las funciones académicas de las universidades públicas, y buscar la calidad, pertinencia y rendición de cuentas.

Aquí, la flexibilidad académica, curricular y pedagógica ha replanteado nuevas formas de pensar la educación, acordes con la globalización y las transformaciones sociales. Una de sus vías es el diseño de competencias para responder a estos cambios y tratar de que los egresados desarrollen las correspondientes al aprendizaje y al desempeño profesional, para que se apliquen en la atención de las necesidades sociales y en el campo laboral.

El currículum ha sido estudiado, analizado e investigado en diferentes momentos históricos y desde distintos enfoques educativos. Furlán señala que es un término polisémico, asociado con "reformas en los sistemas escolares, crisis e innovaciones académicas en las universidades que requerían de nuevas palabras para expresar las ideas". ${ }^{4}$

La educación, los planes de estudio y la pedagogía se transforman con el tiempo y han transitado desde la perspectiva enciclopédica a la tecnología educativa y, posteriormente, a la crítica, con mezclas que llegan a convertirse en eclecticismos absurdos.

3 Saúl Corral García, "La sociedad del conocimiento" [en línea].

4 A. Furlán, "Notas y claves para una introducción en la cuestión del currículo", p. 57. 
Es también un término polimórfico porque adopta la forma particular de las instituciones educativas donde se desarrolla.

El currículum es un proyecto multidimensional de formación para atender las expectativas individuales, las necesidades sociales y el mercado laboral.

Es un proyecto de formación porque tiene su génesis en una posición epistemológica, social y pedagógica. Apple expresa que "Forma parte siempre de una tradición selectiva, de la selección de alguien, de alguna visión de grupo con respecto al conocimiento que se considera legítimo. Se produce a partir de conflictos, tensiones y compromisos culturales, políticos y económicos que organizan y desorganizan un pueblo", 5 porque Incluye la selección, caracterización, organización y evaluación del conocimiento legitimado que se distribuye socialmente mediante los contenidos de un plan de estudios.

Al respecto, Tyler ${ }^{6}$ analiza los filtros filosófico y psicológico de los objetivos y la selección, organización y evaluación del conocimiento; $\mathrm{Taba}^{7}$ profundiza en la naturaleza del conocimiento; $\mathrm{Coll}^{8}$ establece las relaciones del conocimiento y del aprendizaje, y Novack ${ }^{9}$ examina la "estructura conceptual del conocimiento" que es fundamental en la elaboración de planes de estudio.

Se trata de un proyecto multidimensional porque intervienen factores históricos, políticos, económicos, culturales, ideológicos, científicos, sociales e institucionales. Gimeno Sacristán ${ }^{10}$ señala que "el currículum es el eslabón entre la cultura y la sociedad exterior a la escuela y la educación, entre el conocimiento o la cultura heredados y el aprendizaje de los alumnos, entre la teoría (ideas, supuestos y aspiraciones) y la práctica posible, dadas unas determinadas condiciones" que determinan la formación.

5 M. Apple, Cultural politics and education, p. 25.

6 Véase R. W. Tyler, Principios básicos del currículo.

7 Véase H. Taba, Elaboración del currículo.

8 Véase C. Coll, Psicología y currículum.

9 Véase J.D. Novack, Una teoría de la educación.

10 J. Gimeno Sacristán, El currículum; una reflexión sobre la práctica, p. 34. 
La finalidad del currículum es atender las expectativas individuales, las necesidades sociales y el mercado laboral, porque una disciplina y una profesión se interesan en resolver problemas sociales. Whitty sostiene que le da "Respuesta a valores y creencias sociales"; ${ }^{11}$ De Alba afirma que es la "Síntesis de elementos culturales (conocimientos, valores, costumbres, creencias, etc.) que conforman una propuesta político-educativa pensada e impulsada por diversos grupos y sectores sociales cuyos intereses son diversos y contradictorios, propuesta que está conformada por aspectos estructurales-formales y procesales-prácticos, así como por dimensiones generales y particulares que interactúan en el devenir de los currículum." ${ }^{2}$

Se estudia para desarrollar las competencias en diversos sectores sociales y obtener una remuneración económica donde se aplican, de acuerdo a Bernstein, con "Lo que es legítimo saber".

Gimeno Sacristán, desde el enfoque de la reconceptualización, establece que el currículum puede analizarse desde cinco ámbitos formalmente diferenciados:

- Su función social

- El proyecto o plan educativo

- La expresión formal y material de ese proyecto

- Como campo práctico

- Como actividad discursiva y académica e investigativa ${ }^{13}$

Lo cual abre vetas de investigación y de propuestas. Eggleston menciona que en tal proyecto hay tres perspectivas: el currículum formal donde se encuentran las respuestas sobre sus elementos y sus prácticas; el segundo plano es el real, o lo que se lleva a cabo de ese proyecto; y un tercer plano, el no formal, el oculto, que actúa dialécticamente con los anteriores e involucra los aspectos

11 G. J. Whitty, Aproximaciones cambiantes a la política educativa, 1986.

12 A. De Alba, "El currículum universitario ante los retos del Siglo XXI..." p. 33.

13 J. Gimeno Sacristán, El currículum; una reflexión sobre la práctica, p. 15. 
que se dan al interior del aula, de la escuela y del medio social en el desarrollo del proyecto académico. ${ }^{14}$

Un ejemplo sería la adaptación a las normas, la legitimación de ideas, las negociaciones, los contratos pedagógicos, los intereses, los espacios de poder, las relaciones asimétricas entre los sujetos o los grupos pertenecientes a la institución.

En este orden de ideas (Cuadro 1), se propone el fundamento curricular de las ciencias de la información documental con los siguientes planteamientos:

\section{Cuadro 1}

Epistemológico:
Sociedades del conocimiento o de saberes y de la Información
Social:
Derecho a la Información (bibliotecas, centros de información,
centros de documentación y museos) y Derecho de acceso a la
Información (archivos)
Pedagógico:
Constructivismo basado en la Teoría del aprendizaje estraté-
gico.
Se genera con J. Flavell, A. L. Brown, S. Paris, M. Pressley y
otros, y constituye la explicación científica más valiosa al pro-
blema del "aprender a aprender", superando las limitaciones de
otras propuestas; con el paso de los años, ha venido incorpo-
rando ideas de corte constructivista y sociocultural.
- Las personas pueden compensar las limitaciones de su sis-
tema cognitivo con el uso reflexivo e inteligente.
- Implica una compleja actividad reflexiva de toma de deci-
siones.
- La tendencia reciente es la de conceptualizar los esquemas
como complementarios de los modelos mentales.
(Hernández Rojas, Gerardo (2009), "Los constructivismos y sus
implicaciones para la educación", Perfiles Educativos, (38): $38-$
77 ).
Infodiversidad:

En cuanto a la información "[...] las diferencias de contenido y estilo, de formato y de procedencia, de lo efímero y de lo permanente, de lo académico y lo popular, de lo demandado por el gran público y por el especializado, de tener algo que ofrecer a las minorías que forman nuestros espacios vitales" (Morales Campos. E. (1999), "La infodiversidad, los bloques regionales y la cooperación", Transinformação, 11(2):135,)

14 J. Eggleston, Sociología del currículo escolar, p.11. 
Y, de acuerdo a los cuatro Campos de Conformación Estructural del Currículum de Alicia de Alba, ${ }^{15}$ los cuales se aplican a las ciencias de la información documental (Cuadro 2):

Cuadro 2

\begin{tabular}{|c|c|c|c|}
\hline Epistemológico-teórico & Crítico-social & Científico-tecnológico & Práctica profesional \\
\hline $\begin{array}{l}\text { 1. Región de conocimien- } \\
\text { tos: } \\
\text { Ciencias de la Información } \\
\text { Documental (Bibliotecolo- } \\
\text { gía, Archivología, Biblio- } \\
\text { grafía y Documentación) } \\
\text { 2. Construcción del } \\
\text { conocimiento a través de } \\
\text { la utilización de los para- } \\
\text { digmas de investigación } \\
\text { social (Empírico-Analítico, } \\
\text { Simbólico y Crítico); de la } \\
\text { investigación biblioteco- } \\
\text { lógica (Físico, Cognitivo y } \\
\text { Social); y de los métodos } \\
\text { históricos }\end{array}$ & $\begin{array}{l}\text { - Diversas realidades } \\
\text { sociohistóricas en el } \\
\text { acceso a la informa- } \\
\text { ción. } \\
\text { - Variantes multidimen- } \\
\text { sionales, factores exó- } \\
\text { genos y endógenos en } \\
\text { el acceso, utilización y } \\
\text { conservación social de } \\
\text { la información. }\end{array}$ & $\begin{array}{l}\text { - Las TIC en las activi- } \\
\text { dades y tareas de los } \\
\text { bibliotecarios. } \\
\text { - Alfabetización social en } \\
\text { el nivel informacional y } \\
\text { en el digital. } \\
\text { - Formación de usuarios } \\
\text { en el manejo de } \\
\text { información en las } \\
\text { bibliotecas híbridas } \\
\text { (impresos, material } \\
\text { audiovisual y virtual) } \\
\text { - Brechas tecnológicas }\end{array}$ & $\begin{array}{l}\text { - Dominantes: } \\
\text { En el tipo de unidades de } \\
\text { información apoyados por } \\
\text { el país } \\
\text { - Emergentes: } \\
\text { La transversalidad de } \\
\text { profesiones y disciplinas } \\
\text { de las CID. } \\
\text { - Decadentes: } \\
\text { Más o menos obsole- } \\
\text { tas por las asimetrías } \\
\text { sociales (hay bibliotecas } \\
\text { y sistemas de información } \\
\text { con tecnología de punta } \\
\text { y otras donde no hay ni } \\
\text { siquiera una computa- } \\
\text { dora) }\end{array}$ \\
\hline
\end{tabular}

Se considera un eje epistemológico y teórico que fundamente la construcción del conocimiento, las actividades y las tareas de la disciplina y de la profesión; un eje histórico que permita contextualizar la valoración, conservación, restauración y preservación de los libros y documentos; un eje metodológico para la realización de investigaciones cualitativas y cuantitativas; y por último, un eje profesionalizante para la organización y difusión en las unidades de información.

Es recomendable valorar el crédito, como tiempo en el aula en la parte virtual y en los ambientes reales, pues la inflexibilidad administrativa hace que los profesores no tengan más opción que el aula, y esto limita el proceso de enseñanza y aprendizaje. Hay que entender que el plan de estudios es un papel, y que quienes le dan

15 A. De Alba, "El currículum universitario ante los retos del Siglo XXI...", pp. $40-43$. 
forma son todos los actores de una entidad académica y que la pedagogía y la evaluación de los estudiantes no se hace con parámetros tradicionales; se valoran los desempeños y que las comisiones curriculares deben integrar a todos los docentes con especialidad en Bibliotecología o Archivología. Las academias deben reunir a profesores de tiempo completo y asignatura.

Es necesario preocuparse por la obsolescencia del conocimiento incorporando nueva bibliografía sin alterar el contenido esencial de los cursos y cuidar que se realice el trabajo docente en la modalidad grupal.

Habrá que considerar que la invisibilidad de los planes de estudio, físicamente y en la red, hace muy difícil realizar investigación y hacer propuestas para el currículum, sin tener posibilidades de realimentación, con lo que hoy requieren la atención de las necesidades sociales y el mercado laboral.

\section{LAS COMPETENCIAS INTERNACIONALES Y NACIONALES}

Expuesto lo anterior, surge la interrogante ¿qué tendencias de formación hay en algunas escuelas de Bibliotecología de la República Mexicana y cuál es la convergencia con algunas propuestas internacionales?

A continuación se presenta un estudio de las competencias planteadas en el Euroreferencial, ${ }^{16}$ el Libro Blanco en Información y Documentación, ${ }^{17}$ en el proyecto del MERCOSUR, ${ }^{18}$ en la Special Library Association ${ }^{19}$ y en México con las de la Universidad Autónoma del Estado de México, la Universidad de Guadalajara, la Uni-

16 Véase European Council of Information Associations, Euroreferencial en información y documentación: competencias y aptitudes de los profesionales europeos de información y documentación, pp. 23- 24.

17 Véase "Libro Blanco en Información y Documentación" [en línea]

18 Véase: Valentim, M. P. (coord.), Ponjuan Dante, G. et al., O profissional da informacão, perfil e atuacão profissional, pp. 17-21.

19 Véase: Special Library Association [en línea]. 
Agendas de Investigación en Bibliotecología...

\section{versidad Autónoma de San Luis Potosí y la Universidad Autónoma de Chiapas en trece categorías, con los siguientes resultados:}

\section{Competencias sobre fundamentos y entorno}

\begin{tabular}{|l|l|l|l|l|l|}
\hline Libro Blanco & Euroreferencial & \multicolumn{1}{|c|}{ MERCOSUR } & \multicolumn{1}{|c|}{ SLA } & \multicolumn{1}{c|}{ Guadalajara } & \multicolumn{1}{c|}{ Toluca } \\
\hline $\begin{array}{l}\text { EO2 } \\
\text { Conocimiento } \\
\text { del entorno } \\
\text { profesional }\end{array}$ & $\begin{array}{l}\text { i02 } \\
\text { Comprensión del } \\
\text { medio profesional }\end{array}$ & $\begin{array}{l}\text { Identificar las } \\
\text { nuevas deman- } \\
\text { das sociales de } \\
\text { la información }\end{array}$ & $\begin{array}{l}\text { Entender las } \\
\text { circunstancias } \\
\text { del entorno }\end{array}$ & $\begin{array}{l}\text { Desarrollar } \\
\text { y operar } \\
\text { programas y } \\
\text { actividades } \\
\text { en apoyo a la } \\
\text { consolidación de } \\
\text { la infraestructura } \\
\text { de información } \\
\text { nacional }\end{array}$ & $\begin{array}{l}\text { Manejo de los } \\
\text { fundamentos } \\
\text { teóricos de las } \\
\text { Ciencias de la } \\
\text { Información }\end{array}$ \\
& & & & & \\
& & & & & \\
\hline
\end{tabular}

Competencias en fuentes de información

\begin{tabular}{|c|}
\hline Euroreferencial \\
\hline i05 Identificación y validación de las fuentes de información \\
\hline
\end{tabular}

\section{Competencias en el desarrollo de colecciones}

\begin{tabular}{|l|l|l|l|l|}
\hline Libro Blanco & Euroreferencial & \multicolumn{1}{|c|}{ MERCOSUR } & \multicolumn{1}{|c|}{ Guadalajara } & \multicolumn{1}{c|}{ San Luis Potosí } \\
\hline $\begin{array}{l}\text { E05 } \\
\text { Gestión de } \\
\text { colecciones y } \\
\text { fondos. }\end{array}$ & $\begin{array}{l}\text { I08 Gestión de } \\
\text { colecciones y } \\
\text { fondos }\end{array}$ & $\begin{array}{l}\text { Seleccionar y } \\
\text { evaluar todo tipo } \\
\text { de material para } \\
\text { las unidades de } \\
\text { información }\end{array}$ & $\begin{array}{l}\text { Identificar y selec- } \\
\text { cionar fuentes de } \\
\text { información apropia- } \\
\text { das para la toma de } \\
\text { decisiones }\end{array}$ & $\begin{array}{l}\text { Identificar las tendencias profesiona- } \\
\text { les para la disponibilidad y utilización } \\
\text { de las fuentes documentales }\end{array}$ \\
\hline $\begin{array}{l}\text { E17 } \\
\text { Técnicas de } \\
\text { adquisición }\end{array}$ & & & $\begin{array}{l}\text { Manejar los principios y métodos } \\
\text { aplicables a la selección y adquisi- } \\
\text { ción de colecciones de unidades de } \\
\text { información }\end{array}$ \\
\hline & & & $\begin{array}{l}\text { Elaborar los documentos normativos } \\
\text { del proceso de desarrollo de colec- } \\
\text { ciones en unidades de información }\end{array}$ \\
\hline & & & $\begin{array}{l}\text { Satisfacer las necesidades de } \\
\text { información de una comunidad } \\
\text { específica a través del desarrollo de } \\
\text { colecciones }\end{array}$ \\
\hline
\end{tabular}




\section{Competencias en organización de la información}

\begin{tabular}{|c|c|c|c|c|c|}
\hline Libro Blanco & Euroreferencial & MERCOSUR & SLA & Guadalajara & San Luis Potosí \\
\hline $\begin{array}{l}\text { EO7 } \\
\text { Análisis y } \\
\text { representación } \\
\text { de la } \\
\text { información }\end{array}$ & $\begin{array}{l}\text { iO4 } \\
\text { Gestión de los } \\
\text { contenidos del } \\
\text { conocimiento }\end{array}$ & $\begin{array}{l}\text { Recolectar, regis- } \\
\text { trar, almacenar, } \\
\text { recuperar y difundir } \\
\text { la información } \\
\text { grabada en cual- } \\
\text { quier medio para } \\
\text { los usuarios de } \\
\text { unidades, servicios } \\
\text { y sistemas de } \\
\text { información }\end{array}$ & $\begin{array}{l}\text { Conocimiento } \\
\text { especializado } \\
\text { del contenido de } \\
\text { los recursos de } \\
\text { información, su } \\
\text { evaluación y filtro }\end{array}$ & $\begin{array}{l}\text { Conocimientos } \\
\text { teóricos y prácticos } \\
\text { para planificar, } \\
\text { organizar técnica- } \\
\text { mente y adminis- } \\
\text { trar unidades de } \\
\text { información como } \\
\text { centros de informa- } \\
\text { ción, bibliotecas y } \\
\text { archivos }\end{array}$ & $\begin{array}{l}\text { Aplicar normas y } \\
\text { estilos bibliográ- } \\
\text { ficos }\end{array}$ \\
\hline \multirow[t]{5}{*}{$\begin{array}{l}\text { E08 } \\
\text { Organización } \\
\text { y almacena- } \\
\text { miento de la } \\
\text { información }\end{array}$} & $\begin{array}{l}\text { IO6 } \\
\text { Análisis y repre- } \\
\text { sentación de la } \\
\text { información }\end{array}$ & $\begin{array}{l}\text { Desarrollar } \\
\text { y ejecutar el } \\
\text { procesamiento de } \\
\text { documentos en } \\
\text { distintos soportes } \\
\text { en unidades, siste- } \\
\text { mas y soportes de } \\
\text { información }\end{array}$ & $\begin{array}{l}\text { Conocimiento } \\
\text { apropiado al traba- } \\
\text { jo de organización } \\
\text { o del cliente }\end{array}$ & $\begin{array}{l}\text { Sistematizar, } \\
\text { ordenar, clasificar, } \\
\text { conservar y organi- } \\
\text { zar la documenta- } \\
\text { ción de cualquier } \\
\text { organización }\end{array}$ & $\begin{array}{l}\text { Valorar los temas } \\
\text { en que se hace ne- } \\
\text { cesaria la elabora- } \\
\text { ción de repertorios } \\
\text { bibliográficos }\end{array}$ \\
\hline & $\begin{array}{l}\text { i09 Enriqueci- } \\
\text { miento de las } \\
\text { colecciones y } \\
\text { fondos }\end{array}$ & & & $\begin{array}{l}\text { Capacidad } \\
\text { para procesar } \\
\text { técnicamente los } \\
\text { documentos (ana- } \\
\text { lizar, catalogar, } \\
\text { clasificar, difundir), } \\
\text { en forma manual y } \\
\text { electrónica }\end{array}$ & $\begin{array}{l}\text { Identificar los } \\
\text { recursos que son } \\
\text { necesarios para el } \\
\text { uso de TIC }\end{array}$ \\
\hline & & & & $\begin{array}{l}\text { Alfabetizar elec- } \\
\text { trónicamente }\end{array}$ & $\begin{array}{l}\text { Utilizar las herra- } \\
\text { mientas básicas } \\
\text { para la utilización } \\
\text { de las TIC }\end{array}$ \\
\hline & & & & $\begin{array}{l}\text { Organizar } \\
\text { sistemas del } \\
\text { conocimiento } \\
\text { con información } \\
\text { gerencial }\end{array}$ & $\begin{array}{l}\text { Capacidad para } \\
\text { ampliar normas } \\
\text { bibliográficas }\end{array}$ \\
\hline & & & & $\begin{array}{l}\text { Organizar bases } \\
\text { de datos docu- } \\
\text { mentales }\end{array}$ & $\begin{array}{l}\text { Elaborar fichas de } \\
\text { trabajo }\end{array}$ \\
\hline
\end{tabular}


Agendas de Investigación en Bibliotecología...

\begin{tabular}{|c|c|c|c|c|c|}
\hline Libro Blanco & Euroreferencial & MERCOSUR & SLA & Guadalajara & San Luis Potosí \\
\hline & & & & $\begin{array}{l}\text { Analizar y procesar informa- } \\
\text { ción documental con base } \\
\text { en normas universales que } \\
\text { permitan el acceso a diferen- } \\
\text { tes tipos de usuarios }\end{array}$ & $\begin{array}{l}\text { Identificar equipo y progra- } \\
\text { mas para la automatización }\end{array}$ \\
\hline & & & & $\begin{array}{l}\text { Localizar y acceder a } \\
\text { recursos de información } \\
\text { relevantes en diferentes } \\
\text { lugares y formatos }\end{array}$ & $\begin{array}{l}\text { Evaluar equipo y programas } \\
\text { para la automatización }\end{array}$ \\
\hline & & & & & $\begin{array}{l}\text { Seleccionar equipo y progra- } \\
\text { mas para la automatización }\end{array}$ \\
\hline & & & & & $\begin{array}{l}\text { Aplicar los diferentes códigos } \\
\text { de descripción adecuados al } \\
\text { tipo de documento }\end{array}$ \\
\hline & & & & & $\begin{array}{l}\text { Identificar los diferentes } \\
\text { lenguajes documentales }\end{array}$ \\
\hline & & & & & $\begin{array}{l}\text { Analizar las necesidades } \\
\text { informativas del usuario y } \\
\text { representar el contenido de } \\
\text { los documentos acorde con } \\
\text { esas necesidades }\end{array}$ \\
\hline & & & & & $\begin{array}{l}\text { Seleccionar el lenguaje } \\
\text { documental adecuado al tipo } \\
\text { de documento }\end{array}$ \\
\hline & & & & & $\begin{array}{l}\text { Representar correctamente } \\
\text { el contenido del documento }\end{array}$ \\
\hline & & & & & $\begin{array}{l}\text { Distinguir las herramientas y } \\
\text { programas que apoyan el di- } \\
\text { seño de recursos y servicios } \\
\text { electrónicos en las unidades } \\
\text { de información documental }\end{array}$ \\
\hline & & & & & $\begin{array}{l}\text { Aplicar las herramientas } \\
\text { tecnológicas para generar } \\
\text { productos electrónicos en las } \\
\text { unidades de información }\end{array}$ \\
\hline
\end{tabular}


Las competencias en los planes de estudio...

\section{Competencias en servicios de información}

\begin{tabular}{|c|c|c|c|c|c|}
\hline Libro Blanco & Euroreferencial & MERCOSUR & SLA & Guadalajara & San Luis Potosí \\
\hline $\begin{array}{l}\text { E01 } \\
\text { Interacción con } \\
\text { los produc- } \\
\text { tores, los } \\
\text { usuarios y los } \\
\text { clientes de la } \\
\text { información }\end{array}$ & $\begin{array}{l}\text { i01 } \\
\text { Relaciones con } \\
\text { los usuarios y } \\
\text { clientes }\end{array}$ & $\begin{array}{l}\text { Capacitar y orien- } \\
\text { tar a los usuarios } \\
\text { para el mejor uso } \\
\text { de las unidades de } \\
\text { información y sus } \\
\text { recursos }\end{array}$ & $\begin{array}{l}\text { Desarrolla y aplica } \\
\text { servicios informa- } \\
\text { tivos pertinentes, } \\
\text { accesibles y efecti- } \\
\text { vos, basados en el } \\
\text { costo, empatados } \\
\text { con la dirección } \\
\text { estratégica de } \\
\text { organización }\end{array}$ & $\begin{array}{l}\text { Producir servicios } \\
\text { de información }\end{array}$ & $\begin{array}{l}\text { Dominar los } \\
\text { principios teóricos } \\
\text { y metodológicos } \\
\text { de los servicios de } \\
\text { información }\end{array}$ \\
\hline $\begin{array}{l}\text { E09 } \\
\text { Búsqueda y re- } \\
\text { cuperación de } \\
\text { la Información }\end{array}$ & $\begin{array}{l}\text { I07 } \\
\text { Búsqueda de } \\
\text { Información }\end{array}$ & $\begin{array}{l}\text { Elaborar productos } \\
\text { de información } \\
\text { (bibliografías, } \\
\text { catálogos, guías, } \\
\text { índices, DSI, etc.) }\end{array}$ & $\begin{array}{l}\text { Brinda instrucción } \\
\text { y apoyo excelente } \\
\text { a los usuarios de la } \\
\text { biblioteca y los ser- } \\
\text { vicios informativos }\end{array}$ & $\begin{array}{l}\text { Realizar estudios } \\
\text { de mercado de ser- } \\
\text { vicios y productos } \\
\text { de información }\end{array}$ & $\begin{array}{l}\text { Identificar las } \\
\text { necesidades de } \\
\text { información del } \\
\text { usuario }\end{array}$ \\
\hline \multirow[t]{3}{*}{$\begin{array}{l}\text { E10 } \\
\text { Elaboración y } \\
\text { difusión de la } \\
\text { Información }\end{array}$} & $\begin{array}{l}\text { i12 } \\
\text { Diseño de } \\
\text { productos y } \\
\text { servicios }\end{array}$ & $\begin{array}{l}\text { Planificar y eje- } \\
\text { cutar estudios de } \\
\text { usuarios/clientes } \\
\text { de la información } \\
\text { y formación de } \\
\text { usuarios/clientes } \\
\text { de la información }\end{array}$ & $\begin{array}{l}\text { Evalúa las nece- } \\
\text { sidades, diseños, } \\
\text { servicios y produc- } \\
\text { tos de información } \\
\text { con valor agregado } \\
\text { para satisfacer } \\
\text { las necesidades } \\
\text { detectadas }\end{array}$ & $\begin{array}{l}\text { Suministrar al } \\
\text { cliente-usuario } \\
\text { la información } \\
\text { documental en } \\
\text { correspondencia } \\
\text { con las necesida- } \\
\text { des identificadas a } \\
\text { través del diseño y } \\
\text { aplicación de ade- } \\
\text { cuados servicios y } \\
\text { medios. }\end{array}$ & $\begin{array}{l}\text { Manejar las fuen- } \\
\text { tes documentales }\end{array}$ \\
\hline & & $\begin{array}{l}\text { Utilizar y diseminar } \\
\text { fuentes, productos } \\
\text { y recursos de } \\
\text { información en } \\
\text { diferentes soportes }\end{array}$ & $\begin{array}{l}\text { Desarrolla produc- } \\
\text { tos de información } \\
\text { especializados } \\
\text { para la utilización, } \\
\text { dentro o fuera, de } \\
\text { la organización } \\
\text { o para clientes } \\
\text { particulares }\end{array}$ & & $\begin{array}{l}\text { Dominar los } \\
\text { principios teóricos } \\
\text { y metodológicos } \\
\text { de los servicios de } \\
\text { consulta. }\end{array}$ \\
\hline & & $\begin{array}{l}\text { Identificar nuevas } \\
\text { demandas sociales } \\
\text { de la información }\end{array}$ & $\begin{array}{l}\text { Evalúa los } \\
\text { resultados del uso } \\
\text { de la información y } \\
\text { además investiga } \\
\text { las soluciones de } \\
\text { los problemas re- } \\
\text { ferentes al manejo } \\
\text { de información }\end{array}$ & & $\begin{array}{l}\text { Identificar las } \\
\text { necesidades de } \\
\text { información del } \\
\text { usuario }\end{array}$ \\
\hline
\end{tabular}


Agendas de Investigación en Bibliotecología...

\begin{tabular}{|l|l|l|l|l|l|}
\hline Libro Blanco & Euroreferencial & MERCOSUR & \multicolumn{1}{|c|}{ SLA } & Guadalajara & \multicolumn{1}{|c|}{ San Luis Potosí } \\
\hline & & $\begin{array}{l}\text { Mejora permanente- } \\
\text { mente los servicios } \\
\text { de información en res- } \\
\text { puesta a los cambios } \\
\text { que se presentan en } \\
\text { las necesidades }\end{array}$ & $\begin{array}{l}\text { Desarrollar las acciones } \\
\text { profesionales que permiten } \\
\text { incidir en la generación, pro- } \\
\text { moción y comercialización } \\
\text { de productos y servicios de } \\
\text { información documental }\end{array}$ \\
\hline & & & & $\begin{array}{l}\text { Tener capacidad para } \\
\text { solucionar problemas }\end{array}$ \\
\hline & & & & $\begin{array}{l}\text { Analizar las necesidades de } \\
\text { información especializada } \\
\text { de los usuarios }\end{array}$ \\
\hline & & & & $\begin{array}{l}\text { Fundamentar los servicios } \\
\text { especializados de infor- } \\
\text { mación }\end{array}$ \\
\hline & & & & $\begin{array}{l}\text { Ser capaz de tomar } \\
\text { decisiones }\end{array}$ \\
\hline
\end{tabular}

\section{Competencias en publicación, edición y duplicación}

\begin{tabular}{|l|l|}
\hline \multicolumn{1}{|c|}{ Libro Blanco } & \multicolumn{1}{c|}{ Euroreferencial } \\
\hline E13 & tO3 \\
Técnicas de reproducción y edición & Publicación y edición \\
\hline
\end{tabular}

\section{Competencias en evaluación}

\begin{tabular}{|l|l|l|}
\hline \multicolumn{1}{|c|}{ Libro Blanco } & \multicolumn{1}{|c|}{ MERCOSUR } & \multicolumn{1}{c|}{ Guadalajara } \\
\hline $\begin{array}{l}\text { EO4 } \\
\text { Identificación, autentificación y evaluación } \\
\text { de fuentes de recursos de información }\end{array}$ & $\begin{array}{l}\text { Reunir y valorar documentos } \\
\text { y proceder a archivarlos }\end{array}$ & Evaluar la información obtenida \\
\hline & $\begin{array}{l}\text { Asesorar en la tasación de } \\
\text { colecciones bibliográficas } \\
\text { documentales }\end{array}$ & \\
\hline & $\begin{array}{l}\text { Realizar peritajes referidos a } \\
\text { la autenticidad, antigüedad, } \\
\text { procedencia y estado de los } \\
\text { materiales impresos de valor } \\
\text { bibliófilo }\end{array}$ & \\
\hline
\end{tabular}


Las competencias en los planes de estudio...

\section{Competencias en gestión de la información}

\begin{tabular}{|c|c|c|c|c|c|}
\hline Libro Blanco & Euroreferencial & MERCOSUR & SLA & Guadalajara & San Luis Potosí \\
\hline $\begin{array}{l}14 \\
\text { Técnicas de } \\
\text { gestión admi- } \\
\text { nistrativa }\end{array}$ & $\begin{array}{l}\text { G01 } \\
\text { Gestión global } \\
\text { de la informa- } \\
\text { ción }\end{array}$ & $\begin{array}{l}\text { Aplicar técnicas } \\
\text { de marketing, lide- } \\
\text { razgo y relaciones } \\
\text { públicas }\end{array}$ & $\begin{array}{l}\text { Cuenta con habili- } \\
\text { dades comerciales } \\
\text { y crea nuevas } \\
\text { oportunidades }\end{array}$ & $\begin{array}{l}\text { Gestionar el } \\
\text { conocimiento de } \\
\text { las organizaciones } \\
\text { empresariales }\end{array}$ & $\begin{array}{l}\text { Capacidad para } \\
\text { aplicar normas } \\
\text { bibliográficas }\end{array}$ \\
\hline $\begin{array}{l}\text { E15 } \\
\text { Técnicas de } \\
\text { marketing }\end{array}$ & $\begin{array}{l}\mathrm{GO} 2 \\
\text { Marketing }\end{array}$ & $\begin{array}{l}\text { Dirigir, administrar, } \\
\text { organizar y coordi- } \\
\text { nar unidades, sis- } \\
\text { temas y servicios } \\
\text { de información }\end{array}$ & $\begin{array}{l}\text { Con los modelos } \\
\text { comerciales y } \\
\text { administrativos } \\
\text { adecuados, comu- } \\
\text { nica a la adminis- } \\
\text { tración superior, } \\
\text { la relevancia de } \\
\text { los servicios de } \\
\text { información }\end{array}$ & & $\begin{array}{l}\text { Identificar la evolu- } \\
\text { ción histórica y so- } \\
\text { cial de las fuentes } \\
\text { documentales }\end{array}$ \\
\hline $\begin{array}{l}\text { E16 } \\
\text { Técnicas } \\
\text { comerciales }\end{array}$ & $\begin{array}{l}\text { GO3 } \\
\text { Venta y difusión }\end{array}$ & $\begin{array}{l}\text { Formular y gestio- } \\
\text { nar proyectos de } \\
\text { información }\end{array}$ & $\begin{array}{l}\text { Es un miembro } \\
\text { eficaz del equipo } \\
\text { administrativo su- } \\
\text { perior y consultor } \\
\text { en lo relativo a } \\
\text { la organización } \\
\text { en materia de } \\
\text { información }\end{array}$ & & $\begin{array}{l}\text { Identificar las } \\
\text { características, } \\
\text { funciones y valor } \\
\text { de las fuentes } \\
\text { documentales }\end{array}$ \\
\hline $\begin{array}{l}\text { E18 } \\
\text { Técnicas de } \\
\text { gestión ma- } \\
\text { croeconómica }\end{array}$ & $\begin{array}{l}\text { GO4 } \\
\text { Gestión presu- } \\
\text { puestaria }\end{array}$ & $\begin{array}{l}\text { Asesorar en el } \\
\text { planeamiento } \\
\text { de los recursos } \\
\text { económico-finan- } \\
\text { cieros y humanos } \\
\text { del sector }\end{array}$ & $\begin{array}{l}\text { Se dedica a la } \\
\text { excelencia en el } \\
\text { servicio }\end{array}$ & & $\begin{array}{l}\text { Identificar las } \\
\text { tendencias } \\
\text { profesionales para } \\
\text { la disponibilidad y } \\
\text { utilización de las } \\
\text { fuentes documen- } \\
\text { tales }\end{array}$ \\
\hline $\begin{array}{l}\text { E19 } \\
\text { Técnica de } \\
\text { instalación, } \\
\text { acondicio- } \\
\text { namiento y } \\
\text { equipamiento }\end{array}$ & $\begin{array}{l}\text { GO5 } \\
\text { Gestión y } \\
\text { proyectos de } \\
\text { planificación }\end{array}$ & $\begin{array}{l}\text { Contribuir a definir, } \\
\text { consolidar y desa- } \\
\text { rrollar el mercado } \\
\text { laboral en el área }\end{array}$ & $\begin{array}{l}\text { Enfrenta desafíos y } \\
\text { busca oportunida- } \\
\text { des dentro y fuera } \\
\text { de la biblioteca }\end{array}$ & & $\begin{array}{l}\text { Fundamentar y } \\
\text { argumentar el pro- } \\
\text { ceso administrativo }\end{array}$ \\
\hline $\begin{array}{l}\text { E20 } \\
\text { Técnicas de } \\
\text { planificación } \\
\text { y gestión de } \\
\text { proyectos }\end{array}$ & $\begin{array}{l}\text { GO6 } \\
\text { Diagnóstico y } \\
\text { evaluación }\end{array}$ & & $\begin{array}{l}\text { Establece alianzas } \\
\text { y asociaciones }\end{array}$ & & $\begin{array}{l}\text { Identificar las } \\
\text { características de } \\
\text { los diferentes en- } \\
\text { foques administra- } \\
\text { tivos en unidades } \\
\text { de información }\end{array}$ \\
\hline $\begin{array}{l}\text { E21 } \\
\text { Técnicas de } \\
\text { diagnóstico y } \\
\text { evaluación }\end{array}$ & $\begin{array}{l}\text { GO7 } \\
\text { Gestión de } \\
\text { recursos } \\
\text { humanos }\end{array}$ & & $\begin{array}{l}\text { Planifica, establece } \\
\text { prioridades y se } \\
\text { centra en lo crítico }\end{array}$ & & $\begin{array}{l}\text { Incidir en la } \\
\text { administración } \\
\text { de organismos } \\
\text { formales }\end{array}$ \\
\hline
\end{tabular}


Agendas de Investigación en Bibliotecología...

\begin{tabular}{|l|l|l|l|l|l|}
\hline \multicolumn{1}{|c|}{ Libro Blanco } & Euroreferencial & MERCOSUR & SLA & Guadalajara & \multicolumn{1}{c|}{ San Luis Potosí } \\
\hline $\begin{array}{l}\text { E22 } \\
\text { Técnicas de ges- } \\
\text { tión de recursos } \\
\text { humanos }\end{array}$ & $\begin{array}{l}\text { I11 } \\
\text { Acondiciona- } \\
\text { miento y } \\
\text { equipamiento }\end{array}$ & & & $\begin{array}{l}\text { Guiar las acciones profesionales que } \\
\text { permiten incidir en la administración } \\
\text { de unidades de información }\end{array}$ \\
\hline & & & & $\begin{array}{l}\text { Aplicar diferentes modelos de planea- } \\
\text { ción administrativa en unidades de } \\
\text { información documental }\end{array}$ \\
\hline & & & $\begin{array}{l}\text { Guiar las acciones profesionales } \\
\text { que permiten incidir en la planeación } \\
\text { de las unidades de información } \\
\text { documental }\end{array}$ \\
\hline & & & $\begin{array}{l}\text { Desarrollar las acciones profesionales } \\
\text { que permiten incidir en la generación, } \\
\text { promoción y comercialización de } \\
\text { productos y servicios de información } \\
\text { documental }\end{array}$ \\
\hline & & & $\begin{array}{l}\text { Capacidad para la solución de } \\
\text { problemas }\end{array}$ \\
\hline
\end{tabular}

\section{Competencias en TIC}

\begin{tabular}{|c|c|c|c|c|}
\hline Libro Blanco & Euroreferencial & MERCOSUR & SLA & San Luis Potosí \\
\hline $\begin{array}{l}\text { E11 } \\
\text { Tecnologías de } \\
\text { información y } \\
\text { comunicación; } \\
\text { informática }\end{array}$ & $\begin{array}{l}\text { t01 } \\
\text { Diseño informático de } \\
\text { sistemas de informa- } \\
\text { ción documental }\end{array}$ & $\begin{array}{l}\text { Ejecutar procedimien- } \\
\text { tos automatizados } \\
\text { propios de un entorno } \\
\text { informatizado }\end{array}$ & $\begin{array}{l}\text { Usa las tecnolo- } \\
\text { gías de informa- } \\
\text { ción adecuadas } \\
\text { para adquirir, } \\
\text { organizar y difundir } \\
\text { la información }\end{array}$ & $\begin{array}{l}\text { Identificar los diferentes re- } \\
\text { cursos que son necesarios } \\
\text { para el uso de las TIC }\end{array}$ \\
\hline \multirow{4}{*}{$\begin{array}{l}\text { E12 } \\
\text { Tecnologías de } \\
\text { información y } \\
\text { comunicación } \\
\text { telemática }\end{array}$} & $\begin{array}{l}\text { TO } \\
\text { Desarrollo informático } \\
\text { de aplicaciones }\end{array}$ & $\begin{array}{l}\text { Planificar, constituir y } \\
\text { manejar redes globa- } \\
\text { les de información }\end{array}$ & & $\begin{array}{l}\text { Utilizar las herramientas } \\
\text { básicas para la utilización } \\
\text { de las TIC }\end{array}$ \\
\hline & $\begin{array}{l}\text { TO4 } \\
\text { Tecnologías de } \\
\text { Internet }\end{array}$ & & & $\begin{array}{l}\text { Identificar equipo y progra- } \\
\text { mas para la automatización }\end{array}$ \\
\hline & $\begin{array}{l}\text { tO5 Tecnologías de } \\
\text { información y comu- } \\
\text { nicación }\end{array}$ & & & $\begin{array}{l}\text { Evaluar equipo y progra- } \\
\text { mas para la automatización }\end{array}$ \\
\hline & & & & $\begin{array}{l}\text { Seleccionar equipo y } \\
\text { programas para la automa- } \\
\text { tización }\end{array}$ \\
\hline
\end{tabular}


Las competencias en los planes de estudio...

\begin{tabular}{|l|l|l|l|l|}
\hline Libro Blanco & Euroreferencial & MERCOSUR & SLA & \multicolumn{1}{|c|}{ San Luis Potosí } \\
\hline & & & $\begin{array}{l}\text { Distinguir las herramientas y programas que apoyan } \\
\text { el diseño de recursos y servicios electrónicos en las } \\
\text { unidades de información documental }\end{array}$ \\
\hline & & & $\begin{array}{l}\text { Aplicar las herramientas tecnológicas para generar } \\
\text { productos electrónicos en las unidades de información }\end{array}$ \\
\hline & & & $\begin{array}{l}\text { Reconocer los programas especializados de cómputo } \\
\text { de acuerdo al tipo de unidad de información documental }\end{array}$ \\
\hline & & & Utilizar programas especializados de automatización \\
\hline
\end{tabular}

\section{Competencias en legislación}

\begin{tabular}{|l|l|l|l|}
\hline \multicolumn{1}{|c|}{ Libro Blanco } & \multicolumn{1}{|c|}{ Euroreferencial } & \multicolumn{1}{c|}{ MERCOSUR } & \multicolumn{1}{c|}{ San Luis Potosí } \\
\hline $\begin{array}{l}\text { EO3 } \\
\begin{array}{l}\text { Conocimiento del marco } \\
\text { jurídico y administrativo } \\
\text { nacional e internacional } \\
\text { de la gestión de infor- } \\
\text { mación }\end{array}\end{array}$ & $\begin{array}{l}\text { iO3 } \\
\text { Aplicación del derecho a } \\
\text { la información }\end{array}$ & $\begin{array}{l}\text { Formular políticas de } \\
\text { investigación en Biblio- } \\
\text { tecología y Ciencia de la } \\
\text { Información }\end{array}$ & $\begin{array}{l}\text { Observar y aplicar la } \\
\text { legislación existente }\end{array}$ \\
\hline & & $\begin{array}{l}\text { Asesorar e intervenir en } \\
\text { la elaboración de normas } \\
\text { jurídicas en Biblioteco- } \\
\text { logía y Ciencia de la } \\
\text { Información }\end{array}$ & $\begin{array}{l}\text { Guiar las acciones profe- } \\
\text { sionales con base en la } \\
\text { legislación vigente }\end{array}$ \\
\hline
\end{tabular}

\section{Competencias en conservación y restauración}

\begin{tabular}{|l|l|l|l|}
\hline \multicolumn{1}{|c|}{ Libro Blanco } & \multicolumn{1}{|c|}{ Euroreferencial } & \multicolumn{1}{c|}{ MERCosUR } & \multicolumn{1}{c|}{ Guadalajara } \\
\hline $\begin{array}{l}\text { EO6 } \\
\begin{array}{l}\text { Preservación, conserva- } \\
\text { ción y tratamiento físico de } \\
\text { documentos }\end{array}\end{array}$ & $\begin{array}{l}\text { i10 } \\
\text { Tratamiento material de } \\
\text { los documentos }\end{array}$ & $\begin{array}{l}\text { Preservar y conservar } \\
\text { los materiales alberga- } \\
\text { dos en las unidades de } \\
\text { información }\end{array}$ & $\begin{array}{l}\text { Recopilar, rescatar y preser- } \\
\text { var la documentación de inte- } \\
\text { rés para el país, instituciones } \\
\text { y empresas (archivos y } \\
\text { patrimonios históricos) }\end{array}$ \\
\hline & $\begin{array}{l}\text { Planificar, coordinar y } \\
\text { evaluar la preservación y } \\
\text { conservación del acervo } \\
\text { documental }\end{array}$ & \\
\hline
\end{tabular}




\section{Competencias en formación}

\begin{tabular}{|c|c|c|}
\hline Libro Blanco & Euroreferencial & SLA \\
\hline $\begin{array}{l}\text { E23 } \\
\text { Técnicas de formación }\end{array}$ & $\begin{array}{l}\text { g08 } \\
\text { Formación y acciones pedagógicas }\end{array}$ & $\begin{array}{l}\text { Se dedica al autoaprendizaje continuo } \\
\text { y la planificación de su carrera }\end{array}$ \\
\hline
\end{tabular}

\section{Competencias en docencia e investigación}

\begin{tabular}{|c|c|c|}
\hline MERCOSUR & Guadalajara & San Luis Potosí \\
\hline $\begin{array}{l}\text { Buscar, registrar, evaluar } \\
\text { y difundir la información } \\
\text { con fines académicos y } \\
\text { profesionales }\end{array}$ & $\begin{array}{l}\text { Diseñar estrategias para la } \\
\text { búsqueda de información } \\
\text { apropiadas a cada recurso } \\
\text { de información }\end{array}$ & $\begin{array}{l}\text { Capacidad para la toma de decisiones en base a } \\
\text { la argumentación y fundamentación lógica }\end{array}$ \\
\hline $\begin{array}{l}\text { Actuar colectivamente } \\
\text { con sus pares en el } \\
\text { ámbito de las instituciones } \\
\text { sociales, con el objetivo de } \\
\text { promocionar y defender la } \\
\text { profesión }\end{array}$ & $\begin{array}{l}\text { Analizar e interpretar los } \\
\text { resultados de la búsqueda } \\
\text { de información }\end{array}$ & Fundamentar el proceso de planeación \\
\hline \multirow{8}{*}{$\begin{array}{l}\text { Realizar investigaciones y } \\
\text { estudios sobre desarrollo y } \\
\text { aplicación de metodología } \\
\text { para elaborar y utilizar el } \\
\text { conocimiento registrado }\end{array}$} & & $\begin{array}{l}\text { Sustentar la evaluación de recursos humanos, } \\
\text { financieros y materiales en las unidades de } \\
\text { información documental }\end{array}$ \\
\hline & & Justificar la toma de decisiones \\
\hline & & $\begin{array}{l}\text { Reconocer el comportamiento de los flujos de } \\
\text { información documental }\end{array}$ \\
\hline & & $\begin{array}{l}\text { Aplicar indicadores bibliométricos en la evalua- } \\
\text { ción de las fuentes y servicios de información } \\
\text { documental }\end{array}$ \\
\hline & & $\begin{array}{l}\text { Resolver problemas métricos relacionados con } \\
\text { las CID }\end{array}$ \\
\hline & & $\begin{array}{l}\text { Tener la capacidad para establecer acuerdos y } \\
\text { convenios de investigación }\end{array}$ \\
\hline & & $\begin{array}{l}\text { Diseñar proyectos innovadores o alternativos } \\
\text { de investigación teórica o práctica utilizando la } \\
\text { metodología cuantitativa o cualitativa }\end{array}$ \\
\hline & & $\begin{array}{l}\text { Sistematizar las investigaciones para construir } \\
\text { conocimientos en ciencias de la información } \\
\text { documental }\end{array}$ \\
\hline
\end{tabular}




\section{Competencias en patrimonio documental}

\begin{tabular}{|l|}
\hline \multicolumn{1}{|c|}{ San Luis Potosí } \\
\hline Reconocer la evolución cultural del documento en tiempo y espacio \\
\hline Identificar las diversas grafías y soportes de la información documental \\
\hline Valorar el impacto social del documento \\
\hline $\begin{array}{l}\text { Reconocer la evolución de las instituciones asociadas con el documento, en sus diferentes manifestacio- } \\
\text { nes en tiempo y espacio }\end{array}$ \\
\hline Reconocer la importancia del patrimonio documental \\
\hline Desarrollar proyectos encaminados a la protección documental \\
\hline Vigilar el cumplimento de las leyes y normas de protección documental \\
\hline Aplicar los diferentes códigos de descripción documental \\
\hline Seleccionar el código de descripción adecuado al tipo de documento \\
\hline
\end{tabular}

\section{CONCLUSIONES}

1. El currículum es un componente vivo de la educación y está en permanente revisión de los constantes cambios sociales.

2. En el análisis internacional, se destacan las competencias comunes en las áreas tradicionales de la Bibliotecología.

3. Se utilizan diferentes tipologías para las competencias.

4. Se usa vocabulario o terminología distinta, de acuerdo con cada región.

5. Las competencias se agrupan de acuerdo con las áreas laborales de cada región

6. Se enfocan de forma diferente las disciplinas y la práctica profesional.

7. El mayor grupo de competencias se centra en la gestión.

8. Sólo dos competencias se estructuran gramaticalmente igual. La E05 (Libro Blanco) y la i08 (Euroreferencial). 
9. En los bloques regionales de Europa y América del Sur las competencias se han analizado y determinado colectivamente. En los Estados Unidos la lista es nacional, mientras que en México cada escuela diseña sus competencias.

10. El Libro Blanco diferencia competencias transversales y específicas.

11. El Euroreferencial ejemplifica los niveles de cualificación.

12. Las competencias de la SLA se enfocan particularmente en el servicio especializado.

13. Es conveniente realizar academias nacionales para identificar problemas comunes en la enseñanza, elaborar antologías, investigar el estado del arte de áreas especificas $\mathrm{y}$ proponer proyectos que beneficien al estudiante $\mathrm{y}$ al propio docente.

\section{REFERENCIAS BIBLIOGRÁFICAS}

Angulo, R. "Aproximaciones a una lógica de investigación curricular", en Orozco, Bertha (coord.), Curriculum: experiencias y configuraciones conceptuales en México, México, Plaza y Valdés, 2008.

Apple, M. Cultural politics and education, New York, Teachers College Press, Columbia University, 1996.

Coll, C., Psicología y currículum, México, Paidós, 1992.

De Alba, A., Conformación conceptual del campo. Evaluación curricular, México, CESU, UNAM, 2002.

De Alba, A., "El curriculum universitario ante los retos del siglo XXI: la paradoja entre posmodernismo, ausencia de utopía y determinación curricular", en De Alba, A. El curriculum universitario de cara al nuevo milenio, México, CESU, UNAM, 1993. 
Del Basto, L., "Reflexión sobre el currículo universitario desde la teoría discursiva de la educación", ieRed: Revista Electrónica de la Red de Investigación Educativa [en línea], 1 (3), 2005, disponible en: http://revista.iered.org.

Eggleston, J., Sociología del currículo escolar, Buenos Aires, Troquel, 1980.

European Council of Information Associations, Euroreferencial en información y documentación: competencias y aptitudes de los profesionales europeos de información y documentación, Madrid, SEDIC, 2004, Vol., 1, pp. 23- 24.

Furlán, A. "Notas y claves para una introducción en la cuestión del currículo", en Foro de análisis del currículum de la Licenciatura en Pedagogía, Memorias, México, 1985.

Gimeno Sacristán, J., El currículum; una reflexión sobre la práctica, Madrid, Morata, 1989.

Goodson, Ivor F., "La construcción social del currículum. Posibilidades y ámbitosdeinvestigacióndelahistoria delCurrículum",RevistadeEducación 295 (1): 7-37, disponible en: http://www.educacion.gob.es/ $\mathrm{dctm} /$ revista-de- educacion/articulosre295/re29501.pdf?documen tId=0901e72b81357 7e4 (consulta: 25 de octubre de 2012).

IV Encuentro de Directores de Escuelas de Bibliotecología y Ciencia de la Información del MERCOSUR, en http://mx.search.yahoo.com/ search? $\mathrm{p}=$ mercosur + competencias+educativas+en+bibliotecologi a\&fr=yfp\&toggle=1\&cop=\&ei=UTF-8\&rd=r1 (consulta: 25 de octubre de 2012).

"Libro Blanco en Información y Documentación", disponible en: http://www.aneca.es/modal_eval/docs/libroblanco_documentacion_ene05.pdf (consulta: 22 de junio de 2012). 
Luengo, González E., "Tendencias de la educación superior en México", disponible en: http:www.tuobra.unam.mx/publicada/ 040829134226.htm (consulta: 3 de enero de 2012).

Marín Marín, A., "La globalización y su impacto en la reforma universitaria mexicana" en http://www.tuobra.unam.mx/publicadas/ 040829134226.html (consulta: 18 de diciembre de 2012).

México, Universidad Autónoma de Chiapas, Licenciatura en Bibliotecología, disponible en: http://secacad.unach.mx/images/stories/ humanidades/bibliotecologia.pdf (consulta: 7 de noviembre de 2012).

México, Universidad Autónoma del Estado de México. Licenciatura en Ciencias de la Información Documental, disponible en: http:// www.emagister.com.mx/licenciatura/licenciaturas_licenciado_ ciencias_informacion_documental-cursos-2312729.htm (consulta: 7 de noviembre de 2012).

México, Universidad Autónoma de Guadalajara, Ciencias de la Información, disponible en: http://www.uag.mx/204/CINF.HTM (consulta: 9 de noviembre de 2012).

México, Universidad Autónoma de San Luis Potosí, Escuela de Bibliotecología e Información, Nuevo plan curricular, San Luis Potosí, UASLP, 2006.

México, Universidad Autónoma de Guadalajara, Ciencias de la Información, en http://www.uag.mx/204/CINF.HTM (consultado el 9 de noviembre de 2012).

México, Universidad Autónoma de San Luis Potosí, Escuela de Bibliotecología e Información, Nuevo plan curricular, San Luis Potosí, UASLP, 2006. 
Novack, J. D., Una teoría de la educación, Ithaca, N. Y., Cornell University Press, 1977.

Special Library Association, "Competencias para bibliotecarios especiales del Siglo XxI: resumen ejecutivo", disponible en: http:// www.sla.org/professional/spanish.html (consultado el 10 de diciembre del 2012).

Taba, H., Elaboración del currículo, Buenos Aires, Troquel 1991.

Tyler, R. W., Principios básicos del currículo, Buenos Aires, Troquel, 1973.

UASLP (2011), Modelo de formación universitaria integral, Documento de Trabajo.

Valentim, M. P. (coord.), Ponjuan Dante, G. et al., O profissional da informacão, perfil e atuacão profissional, São Paulo, Polis, 2000.

Whitty, G., "Aproximaciones cambiantes a la política educativa: el legado de la social-democracia y la respuesta del Thatcherismo", en Fernández E. Marxismo y Sociología de la Educación, Madrid, Akal, 1986. 


\title{
Problemáticas sobre los lectores y la lectura en el horizonte de la investigación bibliotecológica y de la información
}

\author{
ELSA MARGARITA RAMÍREZ LEYVA \\ Universidad Nacional Autónoma de México
}

Mejor, pues, que renuncie quien no pueda unir a su horizonte la subjetividad de su época.

Jacques Lacan

Nuestro tesoro está allí donde se asientan las colmenas de nuestro conocimiento.

Friedrich Nietzsche

\section{INTRODUCCIÓN}

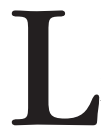

a transformación del Centro Universitario de Investigaciones Bibliotecológicas en el Instituto de Investigaciones Bibliotecológicas y de la Información, IIBI, en éste su Primer Coloquio de Investigación que convocó a la comunidad de investigadores a revisar las agendas de investigación, coincide con los avances del siglo XXI, el cual se distingue por el modelo cultural que concibe el conocimiento, como lo propone Daniel Innerarity, "más que un medio para saber es un instrumento para convivir," un proyecto social global que, en teoría, busca sociedades sin

1 Daniel Innerarity (2011), La democracia del conocimiento, Barcelona, Paidós, p.11. 
desigualdad y una forma de vida ecológica, en la cual la tecnología electrónica haya revolucionado uno de los sistemas vitales de la humanidad: la comunicación. El comienzo del IIBI en un contexto en el que los cambios tienen particular incidencia en nuestra disciplina, brinda la oportunidad de cumplir el deseo de muchos de nosotros de volver a nacer, pero con la experiencia acumulada para rectificar, mejorar, o también, como dice la canción de Edith Piaf, je ne regrette rien (no arrepentirnos de nada) y seguir adelante.

El horizonte de la bibliotecología se ha ido tornando más complejo, pero a la vez fascinante porque sus temáticas se han convertido en el leitmotiv de esta sociedad. No hace muchos años, el universo de la información bibliográfica y documental se mantenía estable en torno a una tradición centenaria de producción, distribución y acceso, en su mayoría, a escritos en soportes de papel impreso y también de imágenes; es el caso de las fotografías, además de la documentación audiovisual, como películas, discos y casettes, todos ellos en formatos analógicos.

En cuanto al universo de los lectores, éste se fue ampliando en la medida en que el número de alfabetizados creció y se elevó su escolaridad; y en cuanto a sus necesidades de información éstas, por lo general, se han orientado hacia la educación, el entretenimiento y las actividades laborales y de la vida cotidiana. Por lo que respecta a sus prácticas de lectura, éstas se habían circunscrito a los materiales escritos que determinaban su organización en formatos establecidos y a la vez ordenaban la lectura de manera que el lector los pudiera leer de manera lineal. Y por lo que se refiere a los espacios, éstos eran el hogar, la escuela, la biblioteca, los transportes y diversos lugares públicos.

Por otro lado, la industria editorial y de entretenimiento ha multiplicado hoy la variedad de sus contenidos y el alcance de los mismos, que cada vez tienen menos restricciones. En cuanto a la institución bibliotecaria, en los dos últimos siglos, ésta ha transitado por diferentes situaciones entre restricciones políticas y económicas, y sus funciones y servicio se han diversificado mucho; en especial la biblioteca pública, cuyo origen fue com- 
plementar la educación de los ciudadanos mediante la prescripción de lecturas pedagógicas, e incluso edificantes, que buscaban el fomento de la lectura y expandir los medios bibliográficos y audiovisuales, a través de servicios móviles, hacia comunidades para las cuales el acceso a la cultura escrita había estado fuera de su alcance.

Por otra parte, la formación de los bibliotecarios se ha ido transformando en paralelo al desarrollo de la bibliotecología, que ha transitado hacia el ámbito científico. De esta manera, durante el siglo Xx, se fueron conformando comunidades académicas en escuelas y facultades con programas de licenciatura y posgrado, así como en centros e institutos dedicados a la enseñanza e investigación de las ciencias bibliotecológicas, de la documentación y la información, como el CUIB, fundado hace 30 años y que dio lugar al actual IIBI.

\section{EL HORIZONTE DE LA LECTURA EN EL CAMPO BIBLIOTECOLÓGICO}

Ahora, en el siglo XXI, parece haber condiciones propicias para revisar el tema de la lectura y los lectores a la luz de las circunstancias, y quizá podría apuntarse hacia un proyecto social que buscará la conformación de sociedades lectoras totales y plenas. Pero antes, sería imperativo que las naciones erradicaran el analfabetismo (conforme a datos de la UNESCO, el 20\% de los adultos del mundo no sabe leer ni escribir, ni tampoco participar plenamente en la organización y actividades de las sociedades de las que forman parte).

Por otro lado, sería necesario impulsar programas para revertir las deficiencias de lectura y escritura de los alfabetizados, cifras que pueden elevarse hasta en un $50 \%$ de la población mundial.

Lo ideal sería formar ciudadanos lectores plenos, capaces de leer diferentes códigos con el fin de que la multialfabetización se constituyera en un medio de aprendizaje autónomo a lo largo de 
toda la vida, y que forjáramos ciudadanos habilitados para utilizar la información que se produce en cualquier parte del mundo y que pudieran transformarse en conocimiento e innovación. Para ello, habría que crear las condiciones de disponibilidad y uso de la información registrada que se produce en cualquier parte del mundo, para permitir conocer el entorno local y también el de otras partes, lo que favorecería la comprensión de las diferencias y de la gran diversidad cultural y social de nuestro planeta. De ahí la insistencia en fortalecer los programas para la formación de lectores plenos.

\section{LA LECTURA Y LOS LECTORES EN EL CAMPO DE LA BIBLIOTECOLOGÍA DEL SIGLO XX}

No está por demás recordar algunos antecedentes sobre la lectura un siglo antes de la creación del IIBI, ya que las ideas de los pioneros de aquellos años podrían ayudarnos a vislumbrar y renovar la agenda de investigación sobre la lectura y los lectores. Precisamente, el estudio de la lectura y los lectores se encuentra entre los temas inaugurales de la investigación bibliotecológica y de la información, surgidos hace casi un siglo. En efecto, en los inicios del siglo $\mathrm{xx}$, hace cien años, surgieron los primeros estudios científicos sobre la lectura en Rusia, Alemania, Estados Unidos y Francia. Se empezaba a cuestionar el empirismo y la subjetividad de los métodos utilizados para conocer los efectos de las lecturas, que se basaban en la frecuencia de préstamos y en el tipo de libros solicitados de los acervos de las bibliotecas públicas. Décadas antes, el Barón de Watteville realizaba en Francia un estudio acerca de las preferencias lectoras de los franceses con la finalidad de conocer la utilidad de las colecciones de las bibliotecas públicas. Los resultados fueron de suma importancia para contar con argumentos que evitaran que en el Congreso Internacional de Bibliotecarios, celebrado en Londres en 1877, progresara la moción de impedir que las bibliotecas tuvieran 
obras de "imaginación", por considerarlas nocivas para las mentes inexpertas, pero también se sostenía que le restaban tiempo a la lectura de los "buenos libros" que ofrecían dichas bibliotecas. Gracias a la tenaz defensa del Barón de Watteville, quien encontraba gran placer en la lectura de esas obras, se logró convencer a los participantes acerca de la importancia que tenían éstas para la promoción de la lectura.

Entre los pioneros del estudio científico de los lectores en el ámbito bibliotecario se encuentra el ruso Nikolai A. Roubakine, fisicomatemático y bibliotecario, escritor de cuentos y editor de libros y guías bibliográficas. El desarrollo de la teoría que inicia en su país gira alrededor de tres ideas centrales: la primera es que los libros y las personas son una unidad, los libros representan a las personas: las personas que los escribieron y a las personas que los leen; la segunda es que cuando una persona aprende a leer, tiene a su alcance todo el conocimiento humano; y la tercera, que la biblioteca sirve como intermediaria entre el autor y el lector. ${ }^{2}$ Roubakine articula las experiencias entre la psicología y el libro en la bibliología para dar lugar a la bibliopsicología, y su método consiste en medir la proyección que hace cada lector en el libro, buscando distinguir en la impresión que causaba éste en cada uno: qué dependía del lector y qué del autor; así, cada palabra, se consideraba como una unidad capaz de evocar reacciones psicológicas diferentes en cada lector. Una vez radicado en Ginebra, Suiza, Roubakine fundó en 1922 el Instituto de Investigación Bibliopsicológico, dedicado al estudio de los lectores.

Por otra parte, en Alemania, el sociólogo Walter Hoffman dirigía el Instituto para la Lectura y la Escritura de la Oficina Central Alemana como responsable de la Biblioteca Pública, donde impulsó las investigaciones sobre los intereses y los hábitos de la lectura, cuyos resultados se tomarían en cuenta para seleccionar adecuadamente los libros y su catalogación con notas sucintas, pero explícitas, que facilitaran la elección y promovieran los libros entre la población.

2 Cfr. Alfred Erich Senn, Nicholas Roubakine. A life for books, Mass., Oriental Research Partners, ORP, 1977, pp. 7-8 
En Estados Unidos, en 1926, se fundó la primera Escuela de Graduados de Bibliotecología, en la Universidad de Chicago, bajo el destacado liderazgo académico del profesor Douglas Waples, quien promovió que la bibliotecología adquiriera un estatus científico resaltando uno de los temas que inaugura la investigación bibliotecológica: el estudio de los lectores, tema que dio lugar a intensas discusiones y a las primeras reflexiones destinadas a formular una filosofía y una ciencia bibliotecológica, así como a definir la función social de las bibliotecas, y también la importancia de la investigación científica de la lectura. Precisamente, el doctor Waples involucró a estudiantes de doctorado en proyectos de investigación sobre la lectura, en los que introdujo métodos sociológicos. También coordinó las investigaciones nacionales, en Estados Unidos, What people want to read about (¿Sobre qué quieren leer las personas?) (1931) y What reading does to people (¿Qué les hace la lectura a las personas?) (1940), cuya finalidad era analizar los efectos de la lectura en la conducta lectora de los estadunidenses.

Jesse Shera consideró a Waples como el pionero de la epistemología social por sus estudios en ese campo, no tanto porque él acuñara este neologismo (la autora fue Margaret E. Egan), sino por sus indagaciones, cuya finalidad era reunir evidencias científicas sobre los modos en que la sociedad construye el conocimiento y los cambios que operaban sus lecturas, y sobre la función que desempeñaba ahí la institución bibliotecaria. El tema de la lectura condujo a Waples a introducir la idea del conocimiento como un objeto interdisciplinario y social, y con ello, abrió una perspectiva innovadora a los estudios bibliotecológicos.

Estos precursores europeos y norteamericanos de principios del siglo $\mathrm{xx}$ que se ocuparon de estudiar a los lectores en el ámbito bibliotecario, coincidieron en la profundización de las dimensiones sociales y psicológicas de los lectores mediante el estudio de las prácticas de lectura, así como en los efectos de los contenidos de los textos en los lectores. Las investigaciones aspiraban también a determinar las relaciones entre los lectores, la lectura, la institución bibliotecaria y la industria editorial. Al 
mismo tiempo se empezaron a distinguir las diferencias entre los públicos lectores y, con ello, la complejidad y la diversidad de la actividad lectora de los ciudadanos.

La Segunda Guerra Mundial fue un lapso de incubación para los cambios sociales, culturales y tecnológicos. En el tema que nos ocupa, la lectura, casi al inicio de la segunda mitad del siglo $\mathrm{xx}$, recién terminada la guerra, se creó la Organización de las Naciones Unidas para la Educación, la Ciencia y la Cultura, la UNESCO, con la finalidad de crear condiciones entre los países miembros que garantizaran la paz e impulsar y comprometer a los estados miembros para crear programas que reconstruyan la democracia, la libertad y la igualdad. La biblioteca pública es una de las instituciones que recobrará fuerza, ya que se consideraba como una pieza estratégica para apoyar programas de alfabetización y educación, y para garantizar el acceso a los libros como parte del derecho a la información, sin distinciones de ningún tipo. Con tales fines, el organismo antes citado le encargó a un grupo de especialistas la redacción del Manifiesto de la UNESCO sobre la Biblioteca Pública, publicado en 1949. En ese momento, en el discurso bibliotecológico sobre la lectura, aún prevalecía la función escolar de la biblioteca pública; incluso, en el citado Manifiesto, se hace referencia a "la biblioteca pública como universidad popular [...] que ofrece a todos una educación liberal." Pero en el siglo XXI propondríamos la idea de Jorge Larrosa sobre la biblioteca como espacio de formación, ${ }^{4}$ en el cual la lectura vaya más allá de la escuela y se convierta en una posibilidad de permanente transformación de lo humano del ser.

Hacia la década de los años sesenta, en especial en Francia, surge la preocupación por la posible muerte del libro y sus lec-

3 United Nations Educational, Scientific and Cultural, Organization, The public library a living force for popular education, París, 16 May 1949, en: http:// unesdoc.unesco.org/images/0014/001474/147487eb.pdf (consulta: 30 de abril de 2012).

4 Jorge Larrosa (2003), La experiencia de la lectura: estudios sobre literatura y formación, Nueva edición revisada y aumentada, México, Fondo de Cultura Económica, p. 28 y ss. 
tores, a causa de la penetración social de la televisión, el cine, la radio y diferentes modelos estadunidenses de consumo. Incluso los Estados Unidos de América ven con temor el debilitamiento de la lectura de libros, y el gobierno emprende estudios culturales en un momento coyuntural, pues la lectura ya no sólo se considera una temática del campo pedagógico y bibliotecario, sino que se incluye en las agendas de investigación de los sociólogos, antropólogos, historiadores, filósofos, semiólogos, lingüistas y especialistas de la literatura. Estos estudios buscan conocer en profundidad los aspectos históricos, culturales, sociales y psicológicos de los comportamientos de los lectores, al tiempo que dan sustento a la formulación de políticas culturales orientadas a promover la lectura como una actividad placentera, en tanto que la lectura escolarizada se empezó a considerar entre las causas que provocaban el debilitamiento del gusto por la lectura.

Las nuevas versiones de 1974 y 1994 del Manifiesto de la UNESCO sobre la biblioteca pública promovían el fomento del gusto por la lectura como una tarea sustantiva de las bibliotecas públicas, mediante programas de cultivo de la lectura y del programa UNISIST, dirigido a bibliotecas nacionales, académicas y especializadas, con la finalidad de organizar la cooperación internacional, y con miras a la interconexión y al desarrollo de programas de información en el campo de las ciencias exactas, naturales y sociales.

En México, los lectores de libros por gusto se concentraban en porcentajes bajos en relación con la lectura obligatoria entre la población total escolarizada. Por otra parte, durante las últimas tres décadas del siglo $\mathrm{xx}$, se vivieron momentos de crisis económicas que hacían que la compra de libros estuviera fuera del alcance de una gran parte de la población debido a que la industria editorial nacional se encontraba en el preámbulo de una crisis. Nuevos alientos surgieron de las políticas oficiales, entre ellas, el impulso a las bibliotecas públicas que, bajo el liderazgo de la doctora Ana Ma. Magaloni en la Dirección General de Bibliotecas de la Secretaría de Educación Pública, y después de conaculta, a partir de 1983 y hasta el año 2000, cuando el número de bibliote- 
cas se multiplicó en un $300 \%$, con lo cual, como era de esperarse, incrementó la proporción de lectores. En 1985 se creó en esa Dirección el Departamento de Investigación, que, entre otros estudios, realizó tres encuestas nacionales aplicadas en los hogares sobre hábitos de lectura, motivación para leer y uso e imagen de la biblioteca. Otra encuesta se orientó hacia la población infantil para conocer los efectos del taller "Mis vacaciones en la biblioteca", programa de fomento de la lectura que también buscaba conocer la percepción de los bibliotecarios sobre el taller.

En 1986, a pocos años de creado el Centro Universitario de Investigaciones Bibliotecológicas en la UNAM, María Trinidad Román Haza, investigadora considerada como la precursora de investigación sobre el tema de los lectores y la lectura, creó esa línea de estudio en la agenda del Centro. Sus indagaciones sobre usuarios de las áreas de física y química la llevaron a la problemática de la lectura. Sus primeras pesquisas seguían procedimientos teóricometodológicos cualitativos con orientación psicológica; en especial, aplicó la entrevista profunda. Tiempo después, ese tema se incorporó por primera vez en el año 2000, como parte de las reformas del plan de estudios de licenciatura en el Colegio de Bibliotecología de la UNAM, y también en posgrado, en el programa de Maestría en Bibliotecología y Estudios de la Información.

\section{LA LECTURA Y LOS LECTORES EN LA AGENDA BIBLIOTECOLÓGICA Y DE LA INFORMACIÓN}

\section{DEL SIGLO XXI}

El panorama de bibliotecología antes descrito, empezó a transfigurarse en el contexto de la denominada globalización, el cual implicaría un proyecto económico y social que tendería a la interdependencia de las naciones; un modelo cultural que concibe el conocimiento y la diversidad como valores para la vida en común y el desarrollo de todos los habitantes del planeta y la tecnología electrónica, que ha favorecido la intercomunicación global y el 
flujo, transferencia y uso de la información mediante diferentes artefactos digitales, sea en tiempo real o diferido, desde cualquier parte del mundo que cuente con la adecuada infraestructura. Todo ello reúne las condiciones para configurar y transformar una sociedad global, que ya se anunciaba desde la década de los años sesenta y que era favorecida por los medios de comunicación electrónicos.

Esas transformaciones fueron modificando el horizonte bibliotecológico cuando éste se fue poblando de artefactos electrónicos, bases de datos, publicaciones y una gran diversidad de contenidos digitales escritos, audio e imagen, que interactúan cada vez más en la modalidad hipertextual. Todo este universo, sumado a los medios impresos, no sólo ha ensanchado la oferta bibliográfica y documental, sino que ha dado lugar a la multiplicación de información y a las opciones para acceder a contenidos, más que a poseer los objetos documentales, lo cual ha facilitado las modalidades de acceso cada vez más rápido y con cobertura mundial. Ahora, los servicios bibliotecarios en el espacio físico se comparten en la biblioteca virtual.

En cuanto al universo de los lectores, éste se ha diversificado y han surgido tipologías de lectores, y las prácticas de lectura exigen otras habilidades de escritura y lectura, como es el caso de los hipertextos y los textos cortos que combinan letras, números, imágenes y códigos diversos. La clasificación clásica por tipo y cantidad acotados a géneros y frecuencia de lectura, generalmente de libros, parámetro con el que era medida la lectura, hoy está cambiando ante la diversidad de géneros y formatos y las maneras de leer actualmente legitimadas (aunque todavía no se aceptan del todo las modalidades de textos cortos, muy comunes en el medio digital, chat, blogs, Facebook, Twitter, e incluso, los utilizados en presentaciones de power point y en mensajes de celulares, entre otros). De igual manera, una buena cantidad de textualidades han surgido debido a los usos de un variado número de personas que han encontrado modos de crear contenidos por las facilidades de las novedosas aplicaciones tecnológicas y la ampliación de la comunicación virtual, la cual ha incrementado el acceso a la in- 
formación, la diseminación y el intercambio de contenidos entre ciudadanos de manera libre y a través de redes y del correo electrónicos. Sin embargo, no sólo se comparte información; ahora, el ámbito cultural ya no se circunscribe al intercambio local de tradiciones, valores, prácticas, productos y formas de relación y de comunicación entre los integrantes de comunidades que además son locales, sino que se extiende cada vez más entre ciudadanos de diferentes lugares del planeta, asociados en torno a algún tema o aspecto de interés común. Estas formas de vida virtual conectadas a través de aparatos móviles han diversificado nuevas vías, incrementado la escritura y la lectura.

El universo actual de lectura, lectores, información y comunicación, puede convertirse en fortaleza para la investigación bibliotecológica de la información pues, como ya lo señalaba Jeese Shera desde 1972, "no se puede negar el hecho de que en toda la historia de la humanidad, ésta nunca había encontrado más necesidad de conocimiento que ahora: conocimiento que únicamente la biblioteca estaría preparada para proporcionar". 5 Ese desafío, al mismo tiempo, abre una oportunidad para renovar nuestra disciplina y su lazo social, y un campo fértil que se nos presenta para participar en la formación de lectores. Ante esta mayúscula tarea, hoy es un momento muy oportuno para repensar la siguiente sentencia de J. Shera: "el éxito de la biblioteca depende de que se conozcan y comprendan las necesidades de información de la sociedad. El bibliotecólogo, como mediador entre el ser humano y su registro gráfico, se sitúa en el punto en que el hombre y el libro se cruzan en una fructífera experiencia intelectual. Por ello, el bibliotecólogo debe conocer: ¿Qué es un libro para que el hombre pueda conocerlo? Y ¿qué es un hombre para que pueda conocer qué es un libro?"6

Estos planteamientos propuestos por Shera no pierden vigencia, por el contrario, hoy resultan de una gran pertinencia: el lector, la lectura, el libro y la biblioteca siempre están sujetos

5 Jesse Shera (1990), Los fundamentos de la educación bibliotecológica, MéxiCO: UNAM, CUIB, p. 41.

6 Ibíd. 
a transformación porque se renuevan con los cambios sociales, políticos, económicos, culturales y tecnológicos. Y puesto que forman parte de los conceptos fundamentales de nuestra disciplina, consideramos integrarlos en la agenda del IIBI, a la luz del contexto actual, dado que los cambios arriba expuestos tienen alcances en los paradigmas, modelos y fundamentos de la bibliotecología y la información, la educación bibliotecológica y la práctica bibliotecaria. Por ello, proponemos incluir las siguientes cuestiones, con el fin de emprender investigaciones teórico metodológicas que nos den luces para construir propuestas para el desarrollo de sociedades capaces de transformarse y dirigirse hacia el perfeccionamiento de las facultades humanas: la libertad, la responsabilidad, la equidad, la solidaridad, fundamentales en un mundo globalizado que privilegia el conocimiento y las oportunidades de progreso de todos los ciudadanos por igual. Las cuestiones que deben considerarse a la luz de cambios del siglo XXI son:

- ¿Qué es la lectura?

- ¿Qué es un libro para que los lectores puedan conocerlo?

- ¿Qué es un lector -más pertinentemente, los lectores, en virtud de su diversidad- para poder conocer qué es un libro?

- ¿Qué es la lectura para que la biblioteca sea un espacio de formación?

- ¿Qué es la biblioteca para que la lectura pueda ser una experiencia de formación y transformación?

- ¿Qué es un bibliotecólogo para que la biblioteca pueda ser un espacio de formación de lectores?

Estas preguntas nos llevan, a su vez, a diseñar metodologías que permitan formular respuestas para las cuales, dada su complejidad, será necesario recurrir a las disciplinas humanísticas, a las ciencias sociales y a otras más, a fin de no soslayar precisamente la complejidad de los temas, dado que en esa complejidad se encuentran las posibilidades de la bibliotecología para asumir un liderazgo en la formación de sociedades lectoras que puedan transformarse y transformar al mundo. 


\section{LA LECTURA PARA TRANSFORMAR \\ LA INFORMACIÓN EN CONOCIMIENTO}

La formación de lectores implica el retorno al lector; dicho en otras palabras, traerlo al centro de la bibliotecología, como lo hicieron los investigadores del siglo xx que mencionamos al principio, ya que el lector, hoy, se ha convertido en otro distinto, en una figura que nos resulta enigmática y que nos abre interrogantes como la que ya planteamos antes, en las cuales éste se constituye en el elemento que le da sentido y significado a los estudios sobre los medios y las formas de armonización entre conocimiento registrado y actividad social, que se diversifican en los fenómenos relacionados con la preservación, la organización, la transferencia, el acceso, la disponibilidad y, finalmente, el uso de los contenidos documentados generados por los integrantes de los heterogéneos sectores de la sociedad.

Y lo mismo sucede con los factores históricos, políticos, culturales, sociales, psicológicos, tecnológicos y administrativos que intervienen en la producción y transfiguración, así como en la comunicación, distribución y uso del capital informativo y cultural que, de igual manera, estudian las diversas maneras de leer, de informarse, los usos sociales, los comportamientos, necesidades, características, representaciones, prácticas, el modo de apropiación, e incluso, los efectos que se obtienen con la finalidad de potenciar el usufructo de dicho capital y nos conduce al campo de la epistemología social. La suma de todo ello recae, sin duda, en la Biblioteca, y es el lector quien puede darle a todo eso su sentido y significado humanístico y social.

La lectura es uno de los medios para lograr la formación que conduce a hacer del ser humano y del mundo una obra de arte; es decir, a acercar cada vez más el horizonte de una humanidad mejor, más bella, buena y feliz. Pero la lectura no se agota en el proceso de la educación escolar, técnica o académica, ni en la animación y promoción de ella; su activación sobre diversas posibilidades y finalidades, más aún hoy cuando se diversifica, en 
tanto que los objetos pertinentes a la lectura no se circunscriben al registro escrito, pues su espectro es todavía más amplio que el medio escrito. En última instancia, la lectura crítica del propio contexto es indispensable, como proponía Paulo Freire, para que se instaure la autoconciencia de los ciudadanos.

En la medida en que la biblioteca se convierta en un espacio donde los lectores puedan tener experiencias, descubrir y aprender, se conocerán y conocerán el mundo, en el que encontrarán posibilidades de formación, de cambio, de sufrimiento, de placer, de imaginación, de felicidad y de conciencia de sí mismos y de su mundo. Para ello, los bibliotecólogos también deberán convertirse en lectores; es decir, conocer su identidad de lector y de usuario de la información, en la medida en que participen en la transmisión de un don, un regalo que tiene, o debería tener, un contenido de amor, como sugiere Larrosa "dar lo que se debe: leer, no es en el sentido de la obligación que es abrir una deuda y una tarea de la lectura, deuda que sólo se salda asumiendo la responsabilidad de la lectura, la tarea que sólo se cumple en el movimiento de leer." Siguiendo con algunas ideas de Larrosa sobre el profesor, también el bibliotecario que se entrega en su elección, el bibliotecario que comunica y comparte, no debe buscar respuestas sino preguntas: "Leer como la amistad de leer con, se implica en el aprender con, en el encontrarse del aprender. ${ }^{7}$ La amistad y la lectura no están en mirarse uno a otro, sino en mirar todos en la misma dirección. Y en ver cosas distintas. La libertad de la lectura está en ver lo que no ha sido visto, ni pre-revisito, en decirlo."

Los dones que los bibliotecólogos pueden transmitir a sus usuarios son el gusto por la lectura, sus experiencias de lectura y la biblioteca como espacio de formación. Pero se requiere que los bibliotecólogos encuentren respuesta a los planteamientos sobre lo que es hoy un lector, un libro, una biblioteca, un bibliotecólogo.

7 Jorge Larrosa, op .cit. p. 647.

8 ibid., p. 650. 


\title{
De la cultura escrita a la cultura visual: problemas epistemológicos
}

\author{
HÉCTOR Guillermo AlFARO LÓPEZ \\ Universidad Nacional Autónoma de México
}

\begin{abstract}
El hecho de que se establezca una oposición entre algo
llamado cultura escrita y algo llamado oralidad tiende a dividir el mundo de la comunicación en estas dos esferas separadas. Hemos sorteado este error gracias a recientes investigaciones que muestran que las entidades que conocemos como cultura escrita y oralidad se interpenetran $y$ dependen una de otra, y más que ser opuestas son algo así como diferentes formas de experiencia que tenemos a nuestro alcance.
\end{abstract}

Jeffrey Kittay

\begin{abstract}
Dextos e imágenes en una amplia variedad de soportes circulan a lo largo de los múltiples espacios sociales. Libros,

1 periódicos, folletos, pinturas, fotografías, películas, en su acepción clásica, y esto sin hacer referencia a los soportes electrónicos que pasan de una a otra persona, o donde incluso una misma persona transita de un soporte a otro: por ejemplo, libros y fotografías, películas y revistas, son manejadas indistintamente por una sola persona a lo largo de su día cotidiano. Así, puede leer los textos contenidos en un periódico o ver pinturas en un museo o reproducidas en un libro. A la persona, en la mayoría de los casos, sólo le interesa obtener la información inmediata que le ofrecen esos múltiples soportes. Incluso le queda de manifiesto
\end{abstract}


que el medio para acercarse a un texto escrito es leyéndolo y a las imágenes viéndolas, o en el mejor de los casos mirándolas. Además, si se encuentra alfabetizado, cuenta con la competencia necesaria para leer cualquier texto escrito. Mientras que "aparentemente" basta con ver una imagen para saber qué contiene o de qué se trata lo que, por otra parte, pone de manifiesto el desconocimiento que existe para el adecuado acceso a la información contenida en ella: se le regatea el estatus de lectura, para circunscribirla a la inmediatez visual del ver o mirar. También se puede acotar que, para que se diera semejante facilidad de disponibilidad de todos esos tipos de soportes, los avances tecnológicos fueron factor decisivo: en los albores de la modernidad la imprenta de tipos móviles multiplicó exponencialmente la cantidad de textos, mientras que en el ocaso de la modernidad la tecnología cibernética (TIC) produce ad infinitum un torrente de textos e imágenes.

Ahora bien, detrás de la desmesurada cantidad y disponibilidad de diversos soportes de textos e imágenes, se presenta una peculiar gama de problemas epistemológicos con los que se pretende hacer legibles su sentido, desenvolvimiento y proyección futura, así como su significación para el campo bibliotecológico. Algo que queda fuera del foco de atención, tanto de los usuarios de tales soportes como de los estudiosos de la especificidad de cada uno de ellos -sean de textos o de imágenes- es que ambos, en términos históricos, se recortan sobre el fondo de particulares horizontes culturales: la cultura escrita y la cultura visual. A partir de lo cual pueden enunciarse los siguientes problemas: ¿cómo se llevan a cabo los procesos de conocimiento en la cultura escrita, así como en la cultura visual? ¿Qué problemática presenta la intersección de ambas formas culturales? Y la cuestión que se deriva de tales cuestionamientos para la Bibliotecología, ¿cómo ha de asumir este campo de conocimiento las características cognoscitivas de ambas manifestaciones culturales y qué puede ofrecer para propiciar su interpretación?

Una característica de la cultura escrita debe de comenzar con el señalamiento de que no es lo mismo que una cultura con es- 
critura. Puesto que ha habido culturas que sin ser escritas tenían escritura, como es el caso de aquellas culturas en las que la escritura se encontraba circunscrita, poseída, por un muy pequeño sector de la población, como solía ser el sacerdotal. Esa breve casta protegía celosamente el secreto de la escritura y su lectura, evitando que llegara al resto de la población, y en tal posesión fundaba su poder. Mientras la forma cultural en la generación de la información y la transmisión comunicativa que prevalecían entre la población era oral. Por lo que puede decirse que eran culturas orales con escritura. Asimismo, el hecho de que toda la población se encuentre alfabetizada es una condición fundamental, mas no sine qua non, para ser una cultura escrita, puesto que ha habido sociedades en que no toda la integridad de la población se encuentra alfabetizada y puede ser una sociedad fundada en la cultura escrita. Un ejemplo de esto último fue el de la antigua Grecia del siglo v a. n. e., que puede ser calificada como el inicial prototipo de una cultura escrita. Este fue el basamento sobre el que se levantaron los grandes logros de los antiguos griegos: sus creaciones en filosofía, historia, ciencia, literatura, pero en especial sus instituciones sociales y políticas, como ese imperecedero legado griego que es la democracia, estuvieron signados por la cultura escrita. Todo esto nos da la pauta para caracterizar a la cultura escrita como aquella configuración cultural que por instancia de la escritura signa la organización y orientación de una sociedad, lo que implica que las formas de generación, concatenación, transmisión y recepción de la información y el conocimiento, tienen como fundamento determinativo la escritura. Todo lo cual redunda en los individuos en la conformación de una mentalidad y visión de la realidad articuladas por los mecanismos de la escritura.

Para comprender en rigor los procesos cognitivos propios de la cultura escrita, tenemos que remitirnos a la entidad donde adquieren concreción y organicidad: la textualidad. En el sencillo y abismal acto de escritura de un texto se manifiesta la irradiación que permea a las sociedades, dándoles organización y orientación. Pero esto no se dio de manera automática con la simple 
oposición de la escritura; ella misma tuvo que emprender un complejo periplo histórico: en primer término, hubo que dejar atrás las escrituras pictográficas e ideográficas, para luego acceder a las escrituras alfabéticas, las cuales por su carácter fonético resultan uno de los mayores logros del espíritu humano. No resulta exagerado decir que es un fulgurante milagro de la mente humana. El último paso que consuma y consolida el proceso es la transición de la scriptio continua a la escritura con intervalos de separación entre las palabras. Si bien al compás de la práctica de la escritura continua van conformándose las primeras sociedades de cultura escrita, el trayecto se completa con la segmentación del texto, lo que representa su autonomía respecto a la oralidad. Pero gradualmente el texto muestra que por sí mismo puede tener una significación autonómica que expresa, dentro de la lógica de la escritura, una representación de la realidad. Desde ese momento, los procesos de pensamiento se llevarán a cabo a partir y en correlación con la mediación textual. Se piensa teniendo como punto referencial la escritura y lo ya escrito; se reflexiona bajo la vertiginosa sombra de los textos escritos.

Por otra parte, la articulación del texto no sólo va a depender de la separación de las palabras; de hecho, se reconfigura a partir de una segmentación más profunda. Desde el momento en que los conocimientos generados y acumulados por una sociedad se precipitan en la escritura para ser plasmados en un texto, quedan fijados de manera permanente, exorcizando la movilidad y el cambio de la reelaboración propio de la cultura oral. Un conocimiento fijado en un texto puede ser fragmentado, dividido de múltiples maneras y extensiones sin perder su forma: lo que permite su mejor manipulación y desplazamiento tanto en el plano del espacio, la vista puede detenerse a voluntad en cualquier punto del texto, como en el plano del tiempo, se pueden cotejar las diversas partes del contenido textual cualquiera que haya sido el momento en que éstas fueron enunciadas. Esta capacidad de los textos para estabilizar información, mensajes y conocimientos permite mayor amplitud y precisión en su análisis, lo que facilita el desarrollo de la crítica. El manejar una amplia gama de textos 
estabilizados así como el poder analizarlos a profundidad seccionando y cotejando sus múltiples partes, propicia una actitud y una comprensión crítica, sistematizada incluso en enfoques y métodos. Todo lo cual termina por constituir una forma específica de racionalidad; es decir, que se encuentra en consonancia con la organicidad lógica de la escritura del texto.

La racionalidad que propicia la escritura, por otra parte, también va a promover el despliegue del conocimiento científico moderno, acelerado por el surgimiento de la imprenta, a partir de una concepción particular de la especificidad cognoscitiva del texto. David R. Olson ha sustentado la tesis de que cognitivamente el origen de la ciencia moderna se encuentra en la aplicación de la hermenéutica bíblica, específicamente la distinción entre lo dado y lo interpretado a la esfera de la naturaleza. ${ }^{1}$ El texto, al fijar un conocimiento, se convierte en lo dado: en el caso de las sagradas escrituras la palabra de Dios es lo dado plasmado en el texto, el cual es objeto de interpretación humana por medio de la lectura. Para la ciencia moderna lo dado es trasladado al orden natural de los hechos observados, que es interpretado por vía de hipótesis e inferencias; por consiguiente, es la esfera de lo creado por el hombre. Este tipo de interpretación se bifurca en una vía objetiva y otra subjetiva: la primera es la que se funda en las observaciones confiables, mientras que las inferencias son interpretaciones teóricas y, por ende, subjetivas, de tales observaciones. De esta forma, el despliegue de la racionalidad a través de la interpretación muestra en su expresión externa y de manera clara, los procesos cognitivos propios de la cultura escrita. Pero tales procesos cognitivos se expanden de múltiples maneras para signar en su impronta el conjunto social.

Los investigadores Jack Goody y Ian Watt han explicado el efecto de las prácticas de escritura y lectura en el conjunto social, poniendo así en evidencia cómo tales prácticas han sido factor

1 David R. Olson, "Cultura escrita y objetividad: el surgimiento de la ciencia moderna", en: Olson, David R., y Torrance, Nancy (Comps.), Cultura escrita y oralidad, España, Gedisa, 1995. 
determinante para el establecimiento de la cultura escrita. ${ }^{2}$ Estos investigadores centran su atención en cuatro factores que posibilitaron la estructuración y asentamiento de la cultura escrita: a) la cultura alfabética propicia una distinción formal entre el orden divino, el natural y el humano; b) la conformación de instituciones de cultura escrita propicia la diferenciación social; c) lo anterior produce una especialización intelectual profesional en una escala sin precedentes y, d) también da lugar a una amplia variedad de opciones de información, conocimiento y esparcimiento ofrecida por el cuerpo de literatura registrada. Estas cuatro opciones dan lugar a una totalidad altamente compleja de la organización social; a nivel individual, concluyen Goody y Watt, todo esto se refleja en la gestación de una conciencia personal de la individualización. La escritura, al objetivar las palabras y hacer más accesible su significado a una inspección más intensa y prolongada, propicia la fundamentación del pensamiento privado y con él la generación de la conciencia individual.

Sin entrar en mayor explicación en los factores expuestos por dichos investigadores, con ellos se muestra el efecto expansivo de la escritura en las diversas esferas que integran la organización social. Pero lo principal que se desprende de su explicación es que la escritura, en la medida en que se expande por todo el cuerpo social a través de las arterías de la información, se convierte en factor de conocimiento estructurante y orientador de las sociedades fundadas; por consiguiente, en la cultura escrita, circuito que principia con la escritura de un texto, atraviesa al conjunto social estructurándolo y recala en la conformación de la conciencia individual signada por la escritura; y esta conciencia, a su vez, se encuentra en disposición para emprender la escritura de un texto.

En el multisecular desenvolvimiento de la cultura escrita, la biblioteca y el saber bibliotecario tuvieron un papel privilegiado. Las primeras bibliotecas de las que se tiene conocimiento, como la de Ebla, surgieron en sociedades de cultura oral con

2 J. Goody y I. Watt, "Las consecuencias de la cultura escrita", en: Goody, Jack (Comp.), Cultura escrita en sociedades tradicionales, España, Gedisa, 1996. 
escritura para así poder almacenar sus ancestrales registros escritos. Pero fue con el establecimiento de las culturas escritas que las bibliotecas se consolidan, definen su estructura y perfilan su función estratégica dentro de la dinámica de tales sociedades. Así, las bibliotecas se desarrollan al amparo de la cultura escrita, pero cumplen una función fundamental para el desenvolvimiento de su configuración cultural: la biblioteca, a la par de ser la institución en la que se vierte, organiza y transmite la información registrada de las sociedades de cultura escrita, se convierte, por lo mismo, en la instancia que se manifiesta como la conciencia de la racionalidad de tal configuración cultural. Con ello, pasa a ser una de las instituciones legitimadoras de la cultura escrita. Cabe señalarse la racionalidad propia de esta cultura, cuyas características se especificaron líneas atrás, que se reconstituye en las bibliotecas bajo la forma de la concepción y los sistemas de organización de la información que se lleva a cabo en ellas. Por ello, se da una ceñida correlación entre la organización lógica de la escritura y la articulación cognitiva de la biblioteca respecto a la información, privilegiadamente basada en el registro escrito. Conforme avanza históricamente la cultura escrita apuntalando y consolidando su predominio, el saber bibliotecario se constituye en la ciencia bibliotecológica, con lo que así está en consonancia con la etapa superior de la cultura escrita representada por la palabra impresa. Al compás de esto último comienza a manifestarse, inicialmente de manera subrepticia en el horizonte, otra configuración cultural, la cual, a lo largo del siglo xx, hará cada vez más notoria y determinante su presencia: la cultura visual.

Las imágenes han estado siempre presentes en la cultura escrita de manera análoga a como lo estaba la escritura dentro de la cultura oral, presencia marginal, sin influencia determinante. Pero va a ser la eclosión del desarrollo tecnológico la que dará lugar a múltiples medios tecnológicos, productores y reproductores, de un torrente desmesurado e incontenible de imágenes. La presencia omnisciente y omnipotente de las imágenes en las sociedades contemporáneas (posmodernas o hipermodernas, como se les quiera designar) ha abierto un apetito voraz por su consu- 
mo. Las imágenes son ya parte infaltable en el panorama de las sociedades y en la vida cotidiana de las personas, lo que pone en evidencia su creciente importancia determinativa en el mundo actual. Pero esto no implica que la escritura pierda todavía su preponderancia: de hecho, lo que actualmente se está dando es el encabalgamiento, entrecruce, de la cultura escrita y la cultura visual con todas las implicaciones que ello acarrea, que van desde posiciones en las que se exalta a la imagen en detrimento de la escritura, hasta posturas de sesgo iconoclasta en que se ataca a la imagen porque provoca el alejamiento del mundo de la escritura y la lectura textual. Pero tanto la una como la otra no son más que actitudes "normales" de incertidumbre propias de periodos de entrecruce de culturas. Mesianismo y Apocalipsis son los dos rostros de épocas que viven en vilo, en medio de la grieta de dos eras.

La cultura visual se encuentra, por tanto, en expansión, por lo que en este momento va mostrando todo su potencial, así como sus limitantes, lo cual, posiblemente, la lleve en un futuro no tan lejano a ser la configuración cultural predominante, que marque con sus pautas la estructura y orientación de las sociedades. Por lo que también su fundamento epistemológico comienza a ser gradualmente más claro. De manera análoga a la escritura, texto, tal fundamento se discierne en la propia imagen. Del cual aquí se señalan sólo los rasgos determinativos: cada tipo de imagen tiene códigos específicos que la articulan para producir sus mensajes icónicos; así, por ejemplo, pintura y fotografía tienen, cada una, sus códigos propios y particulares conformados a partir de su historia, materiales y las técnicas que producen y organizan la información que cada imagen específica comunica con sus mensajes icónicos. ${ }^{3}$ Así como el proceso de escritura pone en marcha a partir de su articulación lógica un despliegue de la racionalidad, las imágenes, por su parte, ponen en juego todo el sistema perceptivo visual. Lo que significa que es la percepción la que marca el avance y las pautas en la creación y comprensión de la información contenida en los mensajes icónicos. En el ámbito

3 Roman Gubern, Mensajes icónicos de la cultura de masas, Barcelona, Lumen, 1974. 
disciplinar del conocimiento, cabe observar que algunos aspectos de las ciencias y las humanidades (incluso un conocimiento tan teórico y abstracto como la filosofía) han asumido una visión del mundo menos textual y más gráfica. Es cada vez más ostensible la utilización de la imagen científica para el desarrollo del conocimiento en las diversas ciencias naturales. ${ }^{4}$ Esto que se manifiesta en el terreno cognitivo de la imagen se dilata en la esfera social, haciendo sentir su presencia de manera determinativa en la progresiva conformación de la cultura visual. Como señala Nicholas Mirzoeff, lo que caracteriza a la cultura visual en cuanto configuración cultural no es su dependencia de las imágenes en sí mismas, sino por la tendencia a plasmar en imágenes o visualizar la existencia. Y de que aunque esa visualización se ha convertido en algo normal en la era moderna, en la actualidad ha pasado a ser una obligación total. ${ }^{5}$

El ascenso de la cultura visual obliga a replantear problemas en los diversos órdenes de la organización social. De forma cada vez más acelerada, los cambios son mayormente profundos y radicales. De manera ineludible todo este vertiginoso estado de cosas impacta directamente al universo bibliotecológico; es más, puede decirse que este campo de conocimiento, por sus objetos de estudio, se encuentra en gran medida en el centro de tales cambios. Razón por la cual la Bibliotecología se ve llevada a enfrentar en el ámbito iridiscente de la información las implicaciones que conlleva el momento histórico de cruce entre las culturas escrita y visual. Con anterioridad se señaló que las bibliotecas y el conocimiento en ellas generado, respecto a la información en sus múltiples facetas organizativas, respondía al desenvolvimiento de la cultura escrita, pero ahora tal situación obliga a hacer frente al horizonte de la visualidad, esto es, a observar y conocer de forma distinta a como se había hecho hasta el momento la cuestión de las imágenes. Lo que significa comprender el inhe-

4 Elke Köppen (Coord.), Imágenes en la ciencia. Ciencia en las imágenes, México, CEIICH-UNAM, 2009.

5 Nicholas Mirzoeff, Una introducción a la cultura visual, España, Paidós, 2003. 
rente estatuto epistemológico de las imágenes, el cual difiere del de la escritura; pero se debe tener siempre presente que hay puntos de contacto y continuidad entre ellas. De manera análoga a como se subraya en el epígrafe que antecede este texto, en el que se especifica la interacción entre las culturas oral y escrita, así debe comprenderse la relación entre cultura escrita y cultura visual: no son opuestas, muy por el contrario, se interpenetran y dependen una de la otra. Pero esto debe emprenderse desde su fundamento epistemológico: ésa es la tarea que debe acometer la ciencia bibliotecológica para que, en el terreno operativo, sea en las bibliotecas donde se lleve a cabo la interacción en pie de igualdad de la información específica de la escritura y las imágenes, brindando así una visión integral del conocimiento y de la realidad. Lo que nos permite enmarcar a la Bibliotecología como conocimiento crisol de diferentes configuraciones culturales, sin excesos de utópicos, para conformar un mundo más informado y, por ende, más habitable. 


\title{
El proyecto InterPARES: un modelo de investigación archivística colaborativo, multinacional y transdisciplinario
}

\author{
JUAN VOUTSSAS M. \\ Universidad Nacional Autónoma de México
}

n otros documentos se ha presentado ya el proyecto In-
terpares desde un punto de vista técnico, describiendo su
objetivo, contenidos, avances, productos, etcétera. En esta
ocasión, y con motivo de la temática del Coloquio, se describirá el
proyecto desde el enfoque de su agenda de investigación, con el
propósito de que sirva como ejemplo para la eventual construc-
ción de otros proyectos con una estructura similar: colaborativa,
multinacional y transdisciplinaria.

Independientemente de sus bondades y beneficios como proyecto de investigación archivística, éste tiene características de estructura y metodología que lo hacen un modelo muy interesante a seguir para construir otros posibles proyectos, pues ha probado ya su validez como estructura de investigación. El actual proyecto es resultado de un proceso evolutivo. El primer antecedente del proyecto se conoció como The Preservation of the Integrity of Electronic Records, también conocido como el Proyecto UBC -University of British Columbia o Universidad de la Columbia Británica del Canadá-. ${ }^{1}$ Fue desarrollado por investi-

1 The Preservation of the Integrity of Electronic Records, disponible en: http:// www.interpares.org/UBCProject/index.htm 
gadores del campo de la archivística desde 1994 hasta 1997, y su objetivo era simplemente establecer las normas para la creación de registros electrónicos confiables y mantener su autenticidad durante su vida activa y semiactiva. Más adelante, la primera fase del proyecto -InterPAREs 1- estableció los medios para valorar y mantener la autenticidad de los documentos electrónicos una vez que se vuelven inactivos y son seleccionados para su preservación permanente; el grupo de esta etapa abarcó a académicos y profesionales de diversas disciplinas además de la archivística, tales como el derecho, la historia, las tecnologías de información y las comunicaciones, la ingeniería y la química, que provenían de varias regiones del mundo para proponer su enfoque colaborativo. Sin embargo, durante esta etapa, los conceptos clave del proyecto y metodologías fueron extraídos casi exclusivamente de los campos de la diplomática y la ciencia archivística.

Para su etapa 2 y 3, InterPAREs evolucionó más todavía; adicionalmente, contó con un grupo de trabajo multidisciplinario y multinacional que enriqueció aún más su enfoque y lo transformó en transdisciplinario, lo cual lo llevó a su máximo potencial. La segunda fase tuvo como objetivo desarrollar y articular los conceptos, principios, criterios y métodos que garantizan la creación y el mantenimiento de registros precisos y fiables, y la conservación a largo plazo de los documentos auténticos en el contexto de actividades artísticas, científicas y gubernamentales llevadas a cabo utilizando tecnología computacional interactiva y dinámica. El grupo de trabajo añadió, además, a científicos, especialistas de la banca y la industria, artistas y representantes de gobiernos de muchas partes del mundo. Por esto mismo su enfoque se fue volviendo cada vez más transdisciplinario.

Para la tercera fase, InterPARES 3, el proyecto aprovechó sus resultados anteriores y replanteó su objetivo, metas específicas y marco teórico de inicio y se volvió altamente aplicado. En esencia, este proyecto se gestó como un esfuerzo de investigación colaborativa cuyo objetivo era investigar y generar conocimiento original y práctico acerca de la problemática de la preservación de archivos digitales auténticos a largo plazo, y con este conoci- 
miento, habilitar a las organizaciones medianas y pequeñas tanto de instituciones públicas como privadas, responsables de archivos digitales -emanados de actividades gubernamentales o de investigación, artes y entretenimiento, actividades sociales, etcétera-, para que fueran capaces de implementar un adecuado registro de aquellos archivos auténticos que satisfagan los requerimientos de sus organizaciones y las necesidades sociales de sus usuarios para garantizar su autenticidad y fiabilidad a largo plazo.

Las metas u objetivos específicos de la investigación fueron:

- Impulsar un entorno que apoye el objetivo general de mostrar a las instancias regulatorias, de auditoría y tomadores de decisiones de políticas, que las actividades de preservación de archivos documentales digitales son esenciales en cualquier actividad que esas instancias deban regular, auditar o controlar.

- Colaborar con organizaciones, programas o proyectos archivísticos de tamaño pequeño o medio, del sector público o privado, para el desarrollo de políticas, estrategias, procedimientos y planes de acción -sobre todo escalables- que puedan implementar con el fin de preservar materiales documentales digitales que han adquirido o piensan adquirir; todo ello gracias a las recomendaciones y productos resultantes de proyectos de vanguardia tecnológica.

- Asesorar a organizaciones pequeñas y medianas -cuyos archivos son utilizados como casos de estudio- acerca de la aplicabilidad de las recomendaciones de InterPARES y otros proyectos en la creación y mantenimiento de archivos digitales confiables, así como validar los supuestos establecidos en la relación entre los encargados de la preservación y los creadores del archivo.

- Evaluar la aplicabilidad de las soluciones de preservación de los proyectos mencionados en el punto anterior, en casos concretos identificados por los asociados -organizaciones bancos de prueba- por requerir atención inmediata, ya 
sea cuando los archivos digitales se encuentren en su custodia o cuando los mismos aún residan con su creador.

- Elaborar y precisar los principios, teorías, métodos y conceptos provenientes de estos proyectos de investigación a partir de los resultados obtenidos de las acciones anteriores.

- Establecer el cómo y el cuándo esos principios, teorías, métodos y conceptos pueden ser trasladados a otras jurisdicciones, independientemente de su entorno legal, administrativo o cultural. En el caso de no aplicar esto, determinar el porqué de esas circunstancias, precisando las medidas que deben ser tomadas para asegurar la adecuada preservación de los archivos documentales digitales.

- Asesorar a esas organizaciones archivísticas pequeñas y medianas en lo relativo a aspectos legales que hayan sido identificados como obstáculos para la preservación digital a largo plazo, en especial aquellos que atañan específicamente a sus situaciones particulares.

- Formular modelos para cada método posible de preservación y para cada objeto digital a ser preservado identificando, previamente, las implicaciones éticas para las personas y para la sociedad.

- Crear modelos de evaluación capaces de medir el grado de éxito de las soluciones de preservación documental que hayan sido propuestas e implementadas.

- Desarrollar modelos de costos de preservación para diversos tipos de documentos y archivos.

- Desarrollar materiales de sensibilización y educativos que permitan: a) capacitar al personal de las organizaciones de archivo, pequeñas y medianas, para planear y llevar a cabo la preservación digital; b) asesorar a asociaciones profesionales para impulsar la carrera de sus agremiados; c) proveer a los planes y programas de estudio universitarios con contenidos y estructuras para dar cursos acerca de la preservación digital identificando diversas modalidades efectivas antes de otorgarlos. 
- Asegurar la divulgación del conocimiento producido por las investigaciones del proyecto -incluyendo casos reales e historias de éxito- por las comunidades pertinentes, a nivel local, nacional e internacional.

- Establecer una sólida red de investigación y educación acerca de la preservación digital que quede fuertemente arraigada al interior de las comunidades bajo la influencia de las diversas organizaciones asociadas al proyecto, integrando así el trabajo académico con la acción social y comunitaria.

El marco teórico original del cual se partió hace una década era muy difuso, ya que en ese momento prácticamente no existía investigación ni desarrollo acerca de la temática de la preservación de archivos digitales. Una vez planteado un marco teórico mínimo de arranque, se estableció que la primera etapa del proyecto debía dedicarse, precisamente, a investigar y crear una serie de elementos y premisas teóricas que permitiesen fundamentar la teoría acerca de este tema, creando las bases teóricas y conceptuales sobre las cuales basar el resto de la investigación. Es decir, dada la carencia de bases teóricas sobre el tema, era necesario investigar y crearlas antes de poder establecer prácticas, estándares y recomendaciones al respecto. Así, la primera etapa del proyecto se dedicó a este esfuerzo, y como resultado de ella, se establecieron los principios básicos conceptuales sobre los cuales se basarían las siguientes etapas del proyecto.

\section{PRINCIPIOS GUÍA}

Multidisciplinariedad, Interdisciplinariedad, Transdisciplinariedad

Como se mencionó, el proyecto evolucionó a lo largo de estos tres enfoques. En una investigación global acerca de preservación de archivos digitales entran muchas disciplinas: obviamente la Ciencia Archivística, la Diplomática, las Tecnologías de Infor- 
mación y Comunicaciones (TIC), la Ciencia de la Información, y un sinfín de aspectos legales, sociales, económicos, etcétera. Por esta razón, al cambiar las fases del proyecto, una de las premisas seleccionadas que le imprimieron mayor relevancia fue la de la transdisciplinariedad. Originalmente, en un enfoque multidisciplinario, se trata de examinar el mismo problema desde el contexto y enfoque particular de las diversas disciplinas, cada una de ellas por separado, y de buscar una solución dentro del entorno de esa disciplina, pero sin ninguna integración de teorías y métodos, para buscar al final la comparación de los resultados y optar por la mejor solución o soluciones. Posteriormente, se tomó el enfoque interdisciplinario en la medida en que sus objetivos y metas podían ser alcanzados solamente a través de la contribución de diversos aspectos: conocimientos, conceptos, principios y técnicas provenientes de una amplia variedad de disciplinas y campos integrados. Pero podía irse más allá: el enfoque podía y debía ser transdisciplinario. La transdisciplinariedad es multireferencial y multidimensional, mientras que la interdisciplinariedad involucra la transferencia de uno o más métodos o ideas desde una disciplina a la otra. La multidisciplinariedad involucra el análisis del mismo objeto por parte de varias disciplinas; la transdisciplinariedad, como el prefijo "trans" indica, implica pensar al mismo tiempo dentro, a lo largo y fuera de cada disciplina y más allá de todas las disciplinas. Su propósito es lograr un entendimiento de la realidad presente, elemento indispensable para lograr la unidad en el conocimiento. "Rigor, apertura y tolerancia son las características fundamentales de la visión y actitud transdisciplinaria. El rigor en el argumento, tomando en cuenta todos los datos disponibles, es la mejor defensa contra posibles distorsiones. La apertura implica la aceptación de lo desconocido, lo inesperado y lo imprevisto. La tolerancia implica el respeto al derecho de que otros tengan ideas y posturas diferentes a la nuestra"2. El proyecto, entonces, debía estar regido por un enfoque transdisciplinario.

2 Todo proyecto transdisciplinario es por definición disciplinario, interdisciplinario y multidisciplinario, véase: Charter of Transdisciplinarity, disponible en: http://nicol.club.fr/ciret/english/charten.htm. 


\section{LIBERTAD DE INVESTIGACIÓN}

El Proyecto InterPARES no preconiza a priori ninguna perspectiva epistemológica o definición intelectual. De hecho, cada investigador en cada caso de estudio debe identificar las perspectivas, protocolo y metodología que crea más idóneas para su investigación. Por lo mismo, el proyecto InterPAREs fue concebido para ser construido como "conocimiento por capas", lo cual significa que las nuevas partes del conocimiento serían construidas utilizando desarrollos anteriores del mismo proyecto; otra parte lo sería tomando las experiencias y conocimiento de otros proyectos afines y útiles a la preservación documental, y otra parte del conocimiento sería original e inédita, emanada del mismo proyecto.

\section{ORGANIZACIÓN INTERNACIONAL}

Organizativamente, InterPARES está constituido por equipos humanos con un propósito grupal denominados "TEAM". El nombre se seleccionó a propósito con la idea no sólo de representar a un equipo humano sino al propósito de ese grupo: TEAM: -Theoretical Elaborations into Archival Management o "Elaboraciones Teóricas para la Administración de Archivos"-. Por su doble significado, no traducimos la palabra al español y la dejamos en su idioma original. Estos grupos pueden ser regionales, nacionales o multinacionales y todos en conjunto formaron lo que se conoció como la "Alianza Internacional". En su etapa final, la "Alianza Internacional" estuvo formada por los siguientes TEAMs: África, Brasil, Canadá con Estados Unidos, Cataluña, Colombia, Corea, China, Italia, Malasia, México, Noruega, Países Bajos, Reino Unido, Singapur y Turquía. Nuevos TEAMs podían agregarse a la Alianza Internacional enviando una solicitud formal escrita al Director del Proyecto InterPAREs. Éste determinaría la viabilidad de la solicitud y emitiría una recomendación al TEAM Internacio- 
nal, el que opinaría al respecto. La decisión se toma preferentemente por consenso, y de otra forma, por votación.

Cada TEAM tiene un director designado e integra cuatro posibles categorías de participantes en el proyecto: investigadores, asociados, ayudantes de investigación y el grupo de apoyo interno o staff del proyecto en sí. La sede central administrativa para el Proyecto InterPAREs es la Universidad de la Columbia Británica del Canadá, UBC; en particular, su Escuela de Bibliotecología, Archivonomía y Estudios de la Información.

Los investigadores son individuos co-participantes en las actividades de investigación dentro del proyecto. Todos ellos deben ser parte de un TEAM dentro de la Alianza Internacional, desempeñar una parte activa en el trabajo de investigación y las actividades de su equipo en particular, y ser reconocidos dentro del TEAM como tales. Los investigadores pueden ser personal académico, personal profesional adjunto o personal profesional colaborador. Los primeros son responsables de todas y cada una de las áreas o temáticas de investigación cubiertas por el proyecto; los segundos, si bien pueden estar involucrados en todo el proyecto, son específicamente responsables de alguna tarea específica o una parte de la investigación llevada a cabo dentro de la organización particular a la que pertenecen, y los terceros son aquellos profesionales responsables de áreas muy específicas dentro de la investigación y en las que son considerados expertos -derechos de autor, cultura organizacional, etcétera-.

Los asociados son organizaciones que pueden ser de tres tipos: las de banco de prueba, las de recursos y las internacionales. Los asociados a banco de prueba para un proyecto son aquellas organizaciones o programas archivísticos que son utilizados como sede y/o materia de algún proyecto de investigación. Los asociados de recursos son aquellas organizaciones que cuentan con cierto grado de experiencia y/o conocimiento en todo, o sólo en parte, de algún proyecto específico de investigación y que desean compartir esta experiencia con otros investigadores proveyendo insumos de conocimiento, regularmente a través de sitios web así como de talleres y seminarios presenciales, y realizando pruebas 
de productos y resultados preliminares relacionadas con los proyectos. Los asociados internacionales son TEAMs de investigación regionales, nacionales o multinacionales constituidos de forma similar, y comparten los mismos objetivos, preguntas de investigación, metodologías, gobernanza, investigación y actividades de transmisión del conocimiento; todos ellos reportan y retroalimentan a una sede común repositorio en la Universidad de la Columbia Británica del Canadá y son dirigidos y coordinados por el director del proyecto InterPAREs, con el apoyo del personal central del proyecto o staff.

Los ayudantes de investigación son estudiantes que forman parte integral del TEAM al que pertenecen; su tarea es realizar ciertas actividades de investigación dentro un proyecto y siempre bajo la tutela de un investigador. Por lo general son estudiantes de grado. Muchos de ellos utilizan su parte de colaboración como su proyecto de investigación de tesis.

El Grupo Interno de Logística, o staff del proyecto, incluye al grupo de personal de apoyo central del proyecto - un coordinador de proyecto y un coordinador técnico-, así como personal de apoyo en algunos de los TEAMs miembros de la Alianza Internacional; ellos son los responsables de apoyar y proporcionar los requerimientos administrativos y técnicos para el proyecto. El Coordinador del Proyecto es quien asiste de tiempo completo al Director del Proyecto y administra la infraestructura organizacional del proyecto InterPARES. Es responsable de:

- Reportar ante el Director del Proyecto.

- Llevar a cabo las funciones financieras y administrativas del proyecto.

- Mantener al día la información del proyecto.

- Editar y actualizar la información dentro del sitio web del proyecto de conformidad con las políticas del sitio.

- Administrar los archivos del proyecto de conformidad con las políticas de administración de archivos del proyecto. 
Agendas de Investigación en Bibliotecología...

- Facilitar la comunicación e intercambio de información entre los miembros del proyecto, la comunidad archivística y el público en general.

- Coordinar las actividades de los ayudantes de investigación dentro de la Universidad de la Columbia Británica del Canadá.

- Coordinar los talleres de investigación y las Reuniones Cumbre Internacionales.

- Llevar a cabo los preparativos para los talleres, reuniones y eventos cuya sede sea la ciudad de Vancouver, Canadá.

- Compilar y distribuir las memorias de los talleres del TEAM Canadá y de las Reuniones Cumbre Internacionales.

El Coordinador Técnico es quien asiste de tiempo completo al Director del Proyecto y al Coordinador del Proyecto, y quien administra la infraestructura técnica del proyecto InterPARES 3; es responsable de:

- Reportar al Director del Proyecto.

- Administrar el sitio web del proyecto de acuerdo con las políticas del sitio.

- Diseñar, desarrollar y mantener sistemas de información accesibles vía la red para apoyar la administración, comunicación y las actividades de investigación del proyecto.

- Apoyar con herramientas de modelado a las unidades de investigación del proyecto.

- Mantener modelos tipo para formateo, actualización, manejo de versiones y distribución de diagramas de modelado.

- Preservar los archivos del Proyecto Interpares 3.

- Facilitar el acceso a los archivos del proyecto de conformidad con las Políticas de Administración de Archivos.

- Proporcionar apoyo y diseño gráfico para folletos, presentaciones, artículos y reportes.

- Proporcionar apoyo a la administración de sistemas computacionales del proyecto.

- Administrar equipo propio del proyecto. 
- Adquirir o desarrollar herramientas tecnológicas apropiadas a la administración del proyecto y sus investigaciones.

- Capacitar a los investigadores del proyecto en el uso de sistemas de información y herramientas tecnológicas propias del proyecto.

Dentro de cada TEAM pueden existir grupos de investigación para emprender estudios generales y grupos para desarrollo de "casos de estudio". Los primeros son grupos de investigación teórico-práctica con algún objetivo específico preestablecido. Los segundos son unidades de investigación asignadas a un caso de estudio generalmente práctico. Por lo regular, un grupo de investigación para estudios generales estará conformado típicamente por un investigador académico, un investigador adjunto y un par de ayudantes de investigación. De forma semejante, un grupo de investigación para un caso de estudio está formado por un investigador académico o adjunto, un par de ayudantes de investigación, un profesional adjunto, y los miembros de alguna organización asociada para espacio de prueba. El director de un TEAM es por lo general un investigador y tiene además como funciones:

- Identificar potenciales estudios generales o de caso y de ser pertinentes, llevarlos a cabo.

- Analizar y determinar hallazgos, descubrimientos y los resultados de ellos.

- Contestar las preguntas de investigación del proyecto mundial que le fuesen enviadas específicamente.

- Generar los productos esperados.

- Diseminar el nuevo conocimiento hallado por su equipo.

Existe además, internamente, una especie de "Consejo de administración” denominado el Team Internacional. Éste, formado de oficio por todos los directores de cada uno de los TEAMs de la Alianza Internacional y por los Coordinadores Técnicos y de Proyecto, es presidido por el Director del Proyecto InterPARES. El Team Internacional es responsable de: 
Agendas de Investigación en Bibliotecología...

- Determinar la dirección y ajustes del proyecto en su conjunto.

- Establecer los métodos que serán utilizados en cada actividad de investigación.

- Establecer los calendarios de las actividades del proyecto.

- Revisar las investigaciones, hallazgos y productos de cada TEAM.

- Resolver acerca de iniciativas provenientes de algún TEAM en particular.

- Resolver sobre la creación y admisión de un nuevo TEAM a la Alianza.

- Identificar actividades adicionales de investigación, así como sus potenciales huecos.

- Dar por terminadas las actividades, sus hallazgos y sus productos.

Además, cada uno de los miembros del Team Internacional cubre las siguientes funciones:

- Supervisar activamente el avance de cada investigación, los planes de proyectos futuros, y los productos e hitos relacionados con el trabajo de investigación del proyecto InterPARES.

- Decidir acerca de cambios sobre las especificaciones originales de un estudio o sus planes.

- Fungir como árbitro y/o negociador en cualquier conflicto o debate emanados del proyecto.

- Reportar las actividades de investigación y los hallazgos, desarrollos y productos derivados de su TEAM y de sus Correspondientes unidades de investigación; también, revisar, discutir y, si viene al caso, conciliar todo ello con los trabajos presentados por otros miembros.

- Integrar las directrices del TEAM internacional dentro de las actividades de su TEAM local.

- Asignarles tareas y responsabilidades a los miembros de su TEAM local. 
- Asistir a las dos reuniones anuales o designar representante en su lugar.

- Organizar alguna reunión cumbre internacional de otoño o una "minicumbre" internacional de primavera de forma sincronizada con algún congreso internacional dentro de la región geográfica de su TEAM local.

- Identificar oportunidades de diseminación de información y de difusión del proyecto dentro de la región geográfica de su TEAM.

\section{Diseño multi-metodológico}

En términos generales las aproximaciones metodológicas han llevado a investigaciones teóricas e investigaciones aplicadas a través de casos de estudio. En cada caso, las investigaciones podrán ser llevadas a cabo utilizando los métodos y herramientas que cada TEAM correspondiente considere más apropiados para ello. Entre las metodologías que ya han sido utilizadas se observan: modelado, elaboración de prototipos, análisis archivístico y diplomático, revisiones bibliográficas, casos de estudio, etcétera. Obviamente, cada investigación debe desarrollarse a partir de preguntas por resolver planteadas previamente, así como por otros instrumentos ya desarrollados por el TEAM Internacional.

\section{Transferibilidad}

El objetivo ulterior del proyecto consiste en la preservación archivística de naturaleza digital, en lo referente al desarrollo de sistemas para elaborar y mantener documentos de archivo confiables, así como sistemas de preservación de esos documentos que aseguran su autenticidad a lo largo del tiempo. Ello implica que el trabajo desarrollado durante el proyecto en sus variadas áreas disciplinarias debe ser, en primera instancia, traducido y ligado constantemente a términos y conceptos archivísticos. Éstos son los cimientos sobre los cuales se basa la construcción de 
sistemas dirigidos a la preservación documental. En segunda instancia, debe llevarse el conocimiento derivado de las investigaciones al contexto específico y adecuado; es decir, contextualizar los resultados al entorno de su TEAM. No obstante, al momento de completarse cada investigación, los descubrimientos archivísticos deben hacerse accesibles y comprensibles para sus creadores, y para las organizaciones, instituciones y los investigadores académicos. Dicho de otra forma, los resultados de las investigaciones deben ser traducidos de nuevo al lenguaje y terminología de cada una de las disciplinas que requiere hacer uso de ellos. En tercera instancia, los resultados deben redactarse y distribuirse de tal forma que permitan, en su caso, ser reaprovechados y reutilizados por TEAMs u otras organizaciones ajenas al contexto original, y convertirse así en tecnología transferible. Los beneficiarios de este nuevo conocimiento producido por el proyecto y diseminado de esta forma serían entonces:

- Las organizaciones, unidades, programas, etcétera, de tamaño pequeño o medio, públicas o privadas -a quienes, en este documento, denominaremos simplemente como "archivos" de aquí en adelante-.

- Los archivos dotados de pocos recursos.

- Los creadores de documentos archivísticos para quienes esas organizaciones representan a su preservador designado.

- Los archivistas o archivónomos, o cualquier otro profesional que tenga la responsabilidad de asegurar la preservación de archivos digitales auténticos y permanentes.

- La comunidad internacional dedicada a la preservación digital.

- Las comunidades legales.

- Las autoridades competentes.

- Los investigadores de todas las disciplinas.

- Los educadores y capacitadores involucrados con estas actividades. 
- El personal técnico de tecnologías de información y comunicaciones.

- El público en general.

\section{Amplia Divulgación DE RESUlTAdos}

Derivado del principio de transferibilidad, el proyecto InterPARES ha fomentado la creación de trabajos académicos de autoría original, innovadores y bajo los principios de libre expresión e intercambio de las ideas, y se propone divulgarlos de la forma más amplia posible. Por ello, desde la primera etapa del proyecto InterPAREs se ha tratado de hacer el máximo esfuerzo para divulgar al público los trabajos emanados del mismo, tan rápido como sea posible y guardando un adecuado equilibrio con el derecho de los investigadores para desarrollar, sintetizar, evaluar y formalizar sus descubrimientos y resultados previos a su publicación. El sitio web del Proyecto InterPAREs es su sitio oficial y el medio de publicación documental del Proyecto. El sitio web oficial del Proyecto InterPARes se ubica en el dominio: http:// www.interpares.org. Este sitio es una denominación que abarca colectivamente todo un conjunto de archivos digitales estáticos (documentos html, imágenes, archivos pdf, presentaciones ppt, archivos de texto, etcétera), proporcionados por los miembros internacionales del proyecto para ser vistos. En este sitio existe una zona de documentos de uso restringido sólo para los miembros del proyecto y un área abierta totalmente al público. Toda la información y documentos disponibles en el área pública del sitio web están puestos ahí con el propósito de que exista el más libre acceso y la más amplia distribución y uso de las ideas y los contenidos. Tanto el público como los miembros del proyecto están en plena libertad de citar y distribuir los materiales allí encontrados. La zona de información restringida a miembros del proyecto tiene como finalidad distribuir internamente la informa- 
ción provisional y documentos de trabajo entre los miembros del proyecto para su uso y tratamiento interno.

Por su propia naturaleza, el sitio web de InterPAREs y sus contenidos están sujetos a revisiones y actualizaciones permanentes. No obstante, con objeto de guardar la huella en cada etapa una versión del sitio web previa a cada reunión cumbre, ha sido capturada y almacenada. Para facilitar la discusión acerca de actividades de investigación, más allá de los talleres de investigación, los investigadores, ayudantes y miembros del proyecto tienen acceso a un sistema de mensajería electrónica local y restringido -una Intranet-, que les permite subir y descargar mensajes y documentos. Cada TEAM de la Alianza Internacional puede contar además dentro del sitio web del proyecto con una zona exclusiva, un sitio web local con secciones públicas y de acceso restringido. Cada uno de estos sitios web particulares de cada uno de los TEAMs de la Alianza Internacional provee la información pertinente y específica acerca de las actividades y responsabilidades de ese TEAM local dentro del proyecto internacional. Por ejemplo, el TЕАм México tiene su zona dentro del sitio web en servicio desde el 2009, además de una versión local dentro del sitio web del IIBI: http://iibi.unam.mx/archivistica. Todas las publicaciones se hacen en el idioma original del TEAM y se envía una copia en inglés al sitio web del proyecto para su "registro" central.

Este aspecto de las publicaciones es uno de los más sensibles en todo proyecto multinacional, colaborativo y con transferibilidad. Por ello, se desarrollaron específicamente procedimientos para publicar los resultados del proyecto. Estos procedimientos relacionados con los resultados de las investigaciones pretenden:

- Impulsar la investigación y la innovación.

- Proporcionar medios para prevenir, especificar y solventar cuestiones relativas a la propiedad intelectual de los trabajos publicados y a algún otro eventual beneficio.

- Crear los medios para facilitar el acceso y uso público de los resultados de las investigaciones del proyecto. 
Por su misma naturaleza colaborativa y multinacional, fue de suma importancia normar y describir perfectamente las reglas para las publicaciones dentro del proyecto; éste puede ser uno de los aspectos más sensibles del mismo ya que si se omite puede crearse confusión, traslape, falta de normalización en las publicaciones, conflictos entre autores, etcétera; por lo tanto, éste fue un factor clave en el éxito del proyecto. En términos generales, estos procedimientos comienzan con el que es utilizado para someter, aprobar y publicar cada documento oficialmente dentro del proyecto. Contienen además la Guía para Publicar, la Guía para la Investigación Colaborativa, la Guía para los Autores, las especificaciones técnicas y visuales del sitio web del proyecto, etcétera. No es propósito de este documento describirlas aquí con detalle; todas existen publicadas. Simplemente, como ejemplos de sus contenidos, menciono que en ellas se especifica que todas las fuentes de financiamiento público o privado -donativos, apoyos, contratos- deben ser agradecidos apropiadamente en la publicación correspondiente; por lo mismo, no se aceptarían dentro del proyecto donativos o contratos que restrinjan o prohíban la publicación de hallazgos y resultados. Se especifica también que los investigadores deben estar al tanto de que los derechos de patentes pueden verse afectados por la divulgación y, por consecuencia, decidir hasta dónde publicar. En los procedimientos se detallan el Formato Para la Nota Autoral, especificaciones y recomendaciones acerca de la propiedad intelectual y derechos de autor relacionados con las instituciones de origen de los autores, para no entrar en conflicto o duplicaciones; y pueden verse también las Políticas de Administración y Manejo de Archivos del proyecto. Se contemplan las políticas relativas a los aspectos de protección de datos, los cuales deben satisfacer las regulaciones de sus respectivas instituciones y jurisdicción legal. Finalmente, se especifican algunas normatividades con respecto a la "imagen visual" de los documentos emanados del proyecto, a fin de mantener una "imagen corporativa" homogénea dentro de los documentos del mismo. 
El principal documento que contiene lo mencionado anteriormente es el denominado Política Organizacional; ${ }^{3}$ existen más documentos donde vienen algunos otros elementos enunciados previamente los cuales se enlistan en la bibliografía.

\section{REUNIONES Y TALLERES DE INVESTIGACIÓN}

Existen dos categorías de Reuniones de Investigación: Reuniones Cumbre Internacionales y Talleres de TEAMS de Investigación Nacionales / Multinacionales. Ambas son bianuales y se alternan cada año. Los propósitos de las Reuniones Cumbre Internacionales son:

- Establecer planes y proyectos específicos de investigación.

- Determinar actividades de investigación.

- Discutir los avances de las investigaciones.

- Encauzar la dirección de la investigación de manera adecuada.

- Compartir los hallazgos y, en su caso, conciliarlos.

- Decidir acerca de actividades de divulgación.

- Deliberar sobre cualquier asunto llevado a la atención del evento por el Director del Proyecto o por algún miembro de la Alianza Internacional.

Los propósitos de los Talleres de TEAMS de Investigación son:

- Ofrecer a todos los investigadores de los TEAMs, asociados y ayudantes de investigación la oportunidad de debatir académicamente, logrando así el desarrollo de nuevo conocimiento.

3 InterPARES 3: Política Organizacional, Versión final 2.0. Diciembre 2007, actualizado: septiembre 2008. Versión en español traducida por el TEAM México, disponible en: http://iibi.unam.mx/archivistica/mex_politica_organizacional_2_0.pdf. 
- Revisar y discutir estudios de caso y estudios generales de investigación, actividades, hallazgos y productos.

- Distribuir adecuadamente tareas y responsabilidades.

- Realizar actividades de investigación que requieran de la presencia física simultánea de miembros de algún o algunos TEAMs, por ejemplo, la modelación.

Se llevan a cabo dos reuniones anuales: una reunión local de cada TEAM, la cual se realiza en primavera, precediendo a un Simposio de primavera, y una Reunión Cumbre Internacional completa de tres días en el otoño. Estas reuniones internacionales serán organizadas por un TEAM en particular de la Alianza Internacional, en la sede que ellos designen. Cualquier TEAM que sea sede de la reunión de otoño puede a voluntad organizar un simposio, taller o conferencia paralelo en su lugar de origen con fines de divulgación del proyecto. En este caso, los miembros de los otros TEAMs internacionales que así lo deseen pueden participar como ponentes en estos eventos paralelos. Estas formas de divulgación son diferentes de los otros congresos y eventos que la Alianza Internacional organizará ex profeso para divulgar sus conocimientos a nivel mundial.

Los Talleres de los TEAMs de Investigación son acordados para llevarse a cabo en primavera. Es deseable que todos los TEAMs lleven cabo sus correspondientes talleres locales en fechas cercanas para que los trabajos de investigación progresen en forma paralela y para que la producción de materiales sea comparable en cantidad, tipo y grado de desarrollo. De manera típica, un taller de este tipo dura entre tres y cinco días, dependiendo de la cantidad de material que deba ser revisado y de las decisiones ulteriores sobre éste. 


\section{CONCLUSIONES}

Como ha podido observarse, la construcción de un proyecto de investigación colaborativo, multinacional, transdisciplinario, no se reduce simplemente a realizar el típico protocolo de investigación con sus objetivos, metodología, marco teórico, etcétera, y tratar de extrapolarlo geográficamente. Por su misma naturaleza, es todo un proyecto que debe ser planeado, diseñado y construido minuciosamente desde múltiples facetas. Ha podido verse que existen numerosos aspectos que deben ser considerados, discutidos y pactados de antemano entre todas las partes involucradas para su correcto y armónico funcionamiento. Todo ello, además, debe ser claramente escrito y publicado internamente para su cabal conocimiento dentro de todos los miembros del grupo. Nada se deja por sentado y acordado verbalmente.

Si bien un proyecto de esta naturaleza es más complejo de construir y administrar que un proyecto personal o grupal, paga con creces este precio. Los esfuerzos de investigación en una estructura de este tipo no se suman, se multiplican. Bien llevado, la visibilidad del proyecto crece notoriamente y es más fácil conseguir más adelante nuevos patrocinios, investigadores y/o grupos que deseen añadirse al mismo. Sus resultados se divulgan más rápidamente, tienen más impacto y más probabilidades de convertirse en referentes sobre el tema. En lo personal, el intercambio de ideas e interacción con un grupo tan numeroso y heterogéneo de expertos, lo variado de las temáticas, contextos y visiones, enriquece de una manera inusitada el trabajo de todos los involucrados en este tipo de proyectos, independientemente de su papel dentro del mismo. Por supuesto que implica más responsabilidades para todos los integrantes: significa poder trabajar en equipo, seguir planes y tiempos preestablecidos, cumplir metas y plazos, seguir estándares; elementos a los que no todos los investigadores están acostumbrados. No significa que sea un mejor o peor método de investigación: simplemente es diferente y muy rentable. Pero es necesario reflexionar en que si se trata de emprender grandes proyectos y de plantearse ambiciosas metas in- 
vestigativas, ésta es una de las pocas opciones existentes en este mundo globalizado, en esta "sociedad del conocimiento" actual, en la que uno de sus atributos fundamentales consiste en privilegiar el trabajo colectivo sobre la competencia individual. A menos que se cuente con grandes fondos, con notables patrocinios, es una de las opciones que deben ser consideradas si se desea construir proyectos de cierta envergadura y trascendencia con eficiencia además de eficacia, más allá de los proyectos de investigación personal. El Instituto de Investigaciones Bibliotecológicas y de la Información, en ésta su nueva versión como instituto, requiere forzosamente de plantearse proyectos más ambiciosos y trascendentales. La fórmula anterior no es la única posible, pero sí una de las más probadas y utilizadas en la actualidad para este tipo de investigaciones, y debe ser considerada como una de las posibles alternativas para contender con los nuevos compromisos que su calidad de Instituto impone a nuestro quehacer.

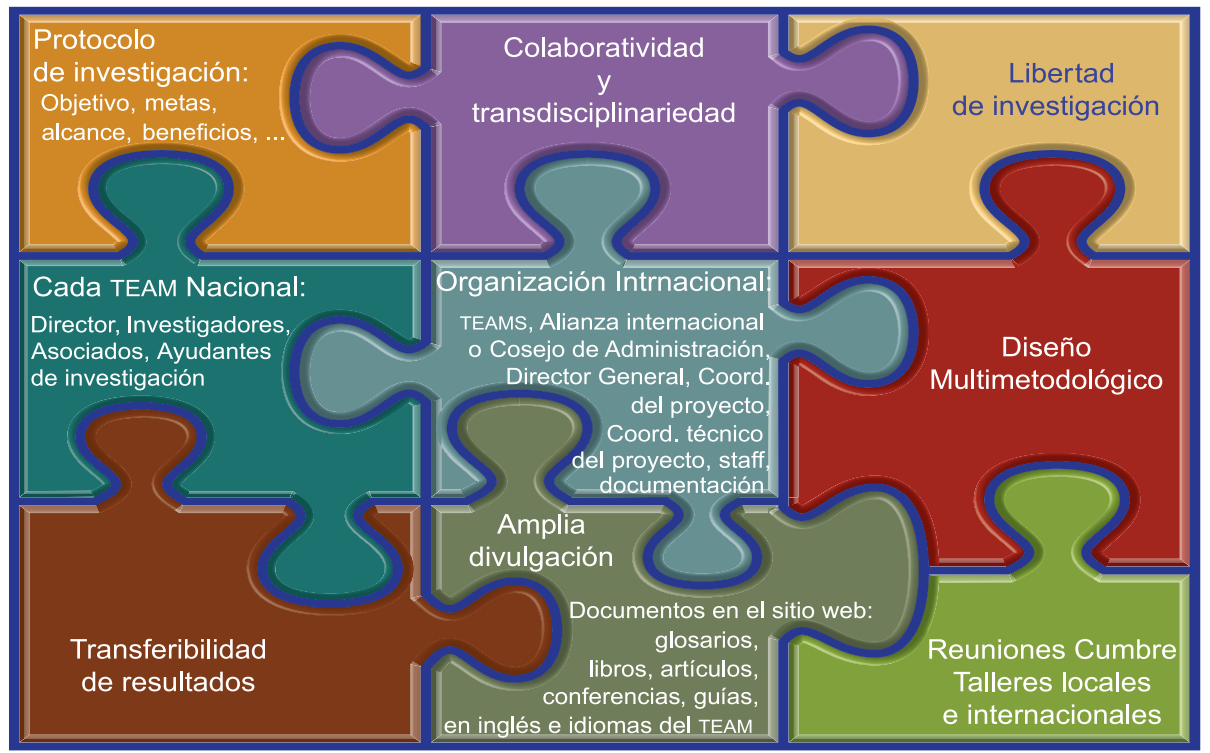

EI Proyecto InterPARES: estructura y principios guía 


\section{REFERENCIAS BIBLIOGRÁFICAS}

"InterpaRes 3: Política Organizacional", Versión final 2.0., Diciembre, 2007, actualizado en septiembre, 2008, Versión en español traducida por el TEAM México, disponible en: http://iibi.unam.mx/ archivistica/mex_politica_organizacional_2_0.pdf.

"InterpARES 3: Marco Teórico", Versión 2.0., Septiembre, 2008, Versión en español traducida por el TEAM México, disponible en: http:// iibi.unam.mx/archivistica/mex_marco_teorico_v2.pdf

"Interpares 3: Metodología Para los Casos de Estudio", Versión 1.0., Mayo, 2009, Versión en español traducida por el TEAM México, disponible en: http://iibi.unam.mx/archivistica/mex_metodologia_casos_estudio.pdf

"InterPARES 3: Principios Metodológicos", Versión 1.0., Mayo, 2009, Versión en español traducida por el TEAM México, disponible en: http:// iibi.unam.mx/archivistica/mex_principios_metodologicos.pdf

"InterPARES 3: Objetivos y Metas", Versión 1.0., Mayo, 2009, Versión en español traducida por el TEAM México, disponible en: http://iibi. unam.mx/archivistica/mex_objetivos.pdf

InterPaRES, Sitio Oficial del Proyecto, disponible en: http://www.interpares.org/ip3/ip3_index.cfm

InterPARES, Sitio del proyecto dentro de la página de archivística del IIBI, disponible en: http://iibi.unam.mx/archivistica, dentro de la sección marcada "InterPARES". 


\title{
La Metría de la Información y del Conocimiento Científico: elementos constitutivos para el diseño de una Agenda de Investigación
}

\author{
SALVADOR GORBEA-PORTAL \\ Y JANE MARGARET RUSSELL-BARNARD \\ Universidad Nacional Autónoma de México
}

\section{INTRODUCCIÓN}

1 diseño de una agenda de investigación en cualquier
campo de conocimiento resulta una tarea compleja que,
además, debe ser concebida como un proceso sometido a constantes revisiones y no como una tarea definitiva y acabada. Para su diseño e implementación, se requiere tener en cuenta los antecedentes teóricos que le dan origen a este proceso, su estructura, sus objetivos y características, así como los elementos esenciales que constituyen el entorno investigativo del campo de conocimiento que se desee integrar en la agenda.

Otro de los aspectos a considerar en el diseño de agendas de investigación se asocia al dominio que el equipo de investigación encargado para estos fines debe tener sobre la historia, las tendencias, el alcance y la delimitación teórica-disciplinar de los problemas que deberán ser incluidos en la agenda. Este último aspecto enfatiza la necesidad de considerar el diseño de agendas de investigación como un proceso para el cual se requiere un alto nivel de especialización de los integrantes del grupo o equipo de investigación encargado de esta tarea, no sólo en las 
bases teóricas sobre el diseño e implementación de agendas, sino también en la experiencia teórico-práctica requerida en la solución de los problemas de investigación que se pretendan incluir en la agenda.

Sin embargo, tanto el personal especializado en este tema como la literatura que se genera sobre el mismo todavía resulta exigua. Una búsqueda pormenorizada sobre Diseño e Implementación de Agendas de Investigación, en las diferentes bases de datos y recursos de información disponibles, identifica un pequeño conjunto de documentos que tratan la temática, entre los que se destacan trabajos sobre recomendaciones y propuestas de agendas de investigación en campos tan disímiles, como: el académico en la educación superior mexicana (Galaz Fontes, 1999); la investigación para el cambio [económico, social y ambiental en las sociedades andinas] (Li Pun y Mares, 2000); las agendas de investigación y universidades de desarrollo (Sutz, 2005); el proceso de de transformación de las instituciones de educación superior (Muro Lozada y Serrón, 2007); la gobernanza e instituciones (Valdés Ugalde, 2008); el uso de la investigación social y educativa (Moreles-Vázquez, 2009). Destaca entre los anteriores un Manual metodológico para la definición de agendas de investigación y desarrollo en cadenas productivas agroindustriales (Castellanos- Domínguez, Torres-Piñeros y Domínguez-Martínez, 2009) por facilitar una guía de aportaciones metodológicas que propicia la identificación de problemas que deben ser incorporados en una agenda de investigación y desarrollo en este tipo de cadena productiva.

La incursión en la definición de agendas de investigación en las Ciencias Bibliotecológica y de la Información todavía resulta más incipiente. En este sentido, han sido identificados algunos esfuerzos aislados en trabajos que tocan el tema indirectamente, encaminados a presentar un balance sobre el desarrollo histórico y las tendencias de la investigación en estas ciencias (Fitzgibbons, 1984; McClure y Hernon, 1991; Rochester y Vakkari, 2003), y otros en los que se llegan a proponer elementos para la integración y la definición de una agenda de investigación. 
Entre estos últimos, merece atención uno de los trabajos más citados en la literatura especializada, el cual integra una agenda de investigación para las Ciencias Bibliotecológica y de la Información en los años ochenta (Cuadra, 1982); la propuesta de agenda del Comité de Investigación de la Asociación de Colegios y Bibliotecas de Investigación (Association of College and Research Libraries, Research Committee, ACRL por su sigla en inglés) en la cual, en ese entonces, se incluían como una de las metas de esa asociación siete áreas y 22 sub-áreas o problemas de investigación en estas ciencias (Townley, 1990); el análisis sobre el efecto que provocan las Agendas Nacionales de Investigación en las indagaciones en Ciencias Bibliotecológica y de la Información (Curran, 1991); la elaboración de un informe del Seminario celebrado en Lisboa, Portugal, en abril de 1992 por el Grupo Consultivo para la Investigación y Desarrollo Aeroespacial (AGARD, por su sigla en inglés) sobre la conformación de una Agenda de Investigación en Información Científica y Técnica, centrada en el Usuario de la Información, el Acceso a la Información y la Organización y Transferencia de la Información (AGARD, 1992); un artículo publicado en la revista Library \& Information Science Research sobre el desarrollo de una agenda de investigación para las bibliotecas académicas en materia de liderazgo (Hernon y Schwartz, 2008) y por último, más recientemente, un artículo publicado en una revista de la Universidad Estatal de Arizona, Estados Unidos, en el que se utiliza como fuente las entrevistas realizadas con actores en el área de políticas sobre lectura en los estados de Michigan, California y Texas, mediante el empleo del modelo de flujos múltiples de Kingdon, para explicar cómo el área de lectura llegó a ser prominente en la agenda de esos gobiernos estatales durante la segunda mitad de los años noventa (Young, Shepley y Song, 2010). Éstos pudieran ser, desde nuestro punto de vista, los referentes más cercanos a la temática tratada en este trabajo.

En varios de estos trabajos se pudieron identificar elementos teórico-conceptuales, metodológicos y aplicaciones prácticas sobre el proceso de definición de agendas de investigación; serán retomados en los apartados siguientes. 
Estos antecedentes académicos, así como la necesidad de iniciar con el proceso de diseño de una agenda de investigación en el recién instaurado Instituto de Investigaciones Bibliotecológicas y de la Información de la Universidad Nacional Autónoma de México (IIBI, UNAM), son un tema promovido a través de su Primer Coloquio de Investigación Bibliotecológica y de la Información, cuyos trabajos se difunden a través de la publicación de esta memoria y constituyeron los motivos para la presentación de esta comunicación en el referido evento, la cual tuvo como objetivo identificar los elementos constitutivos que deben integrar una agenda de investigación en materia de Metría de la Información y del Conocimiento Científico, para lo que se consideró necesario también identificar los antecedentes teóricos, los objetivos y las características generales del proceso de diseño de una agenda de investigación.

\section{ANTECEDENTES TEÓRICOS SOBRE EL DISEÑO DE AgENdas de InVESTigación}

Las bases teóricas del diseño e implementación de las Agendas de Investigación tienen su origen en las políticas nacionales sobre el establecimiento de Agenda Públicas, las cuales son consideradas por los estudiosos de este tema como un proceso político conflictivo y competitivo (Puentes-Markides, 2007), complejo y a menudo polémico (Sutz, 2005), debido a que en cualquier momento miles de temas de interés público merecen o requieren ser considerados por los responsables políticos para su análisis e inclusión en una agenda gubernamental; de ahí que exista una intensa competencia entre los interesados en temas especializados o representantes de grupos sociales para que sus propuestas ocupen un lugar en la agenda política de los Congresos Constitucionales de cada estado o país.

Esta compleja problemática ha sido tema de interés académico de varios estudiosos, quienes han generado un conjunto de teo- 
rías y metodologías encaminados a fundamentar cómo integrar, estructurar y diseñar una agenda pública en determinado ámbito gubernamental, desde el nivel estatal hasta el federal, y en ocasiones con determinada orientación hacia un campo o área de servicio social especializada.

Joanne D. Eustis, quien desarrolló una tesis doctoral sobre la definición de una agenda pública en el campo de los servicios de telecomunicaciones en el Instituto Politécnico de la Universidad Estatal de Virginia, Estados Unidos, teoriza sobre el tema y reconoce a John Kingdon (en 1995), Frank Baumgartner y Bryan Jones (en 1993) como los autores que aportaron las bases teóricas para la formación y definición de agendas públicas (Eustis, 2000: 10), al tiempo que señala que Kingdon define una agenda pública como "una lista de temas o problemas en los que se presta seria atención por parte de funcionarios públicos y las personas fuera del gobierno que se encuentren estrechamente asociados con estos funcionarios, en un momento dado" (Kingdon, 1995: 3, citado por Eustis, 2000: 2).

Kingdon, autor de la teoría de corrientes múltiples, hace hincapié en la formación de las ideas políticas y la manipulación que hacen los responsables o decisores políticos a través de lo que él denomina "ventanas de oportunidad" (Windows of Opportunity) a lo largo de varios años (Eustis, 2000:3). En su teoría, Kingdon explica por qué algunos problemas alcanzan a ser incorporados a la agenda de forma prominente y otros no, para lo cual identifica tres corrientes o flujos separados entre sí:

Flujo del problema: representa información y sucesos que pueden desencadenar una serie de eventos relacionados con la colocación o la eliminación de un tema de la agenda.

Flujo de la política: se refiere al conocimiento o asesoramiento derivado de investigadores, asesores y analistas que ofrezcan alternativas o soluciones que pueden o no ser considerados o utilizados por los tomadores de decisiones.

Flujo del sistema político: la voluntad del sistema político y de los actores para colocar un tema en la agenda (Kingdon, 1995, citado por Puentes-Markides, 2007). 
Estas tres corrientes convergen en momentos críticos para crear una "ventana de oportunidad" que se traduce en problemas, para pasar a la "agenda de decisiones", por disposición legislativa.

Por otra parte, Eustis (2000: 1) destaca que las propuestas teóricas de Kingdon, Baumgartner y Jones sobre la definición de agendas públicas, se refieren a la medida en que su formación o diseño se encuentra influenciado por varios factores, entre los que se destacan los siguientes:

- La definición del problema o cuestión.

- La presencia de políticas alternativas.

- El apoyo presidencial y del grupo de defensa de los intereses.

- La atención de los medios de comunicación.

- Los ciclos políticos.

- La opinión pública, entre otros.

Entre estos factores se reconocen algunos elementos comunes que, como se podrá identificar más adelante, aparecen de forma explícita en la definición y características de una agenda de investigación, como por ejemplo la definición de un problema (de investigación), o el apoyo de grupos (de Investigación) o de los directivos académicos. Los ciclos políticos (académicos), la opinión de expertos en el tema, entre otros, a los que habría que agregar el momento coyuntural o de crisis en la creación de nuevas instituciones y estructuras organizativo-académicas.

Si bien es cierto que las teorías de Kingdon, Baumgartner y Jones tienen varias similitudes y obvias diferencias, hay que reconocer que estos autores están de acuerdo en un conjunto de ideas, entre las cuales Eustis (2000: 4) señala las siguientes:

- La definición de un problema a resolver es fundamental para el proceso de integración y control de una agenda pública, aspecto que cuenta con el consenso general entre los estudiosos del tema.

- Para que un problema llegue a ser incluido en la Agenda Nacional, debe tener una solución ya propuesta. 
- La influencia presidencial (nacional) o gerencial (Instituciones u organizaciones) puede ser decisiva para influir en la conformación de una agenda pública.

- También las coincidencias teóricas entre estos autores pueden ser extensibles al proceso de diseño de las agendas de investigación, puesto que como ya se indicó más arriba la definición de uno o varios problemas de investigación resultan decisivos para su conformación. En la agenda de investigación también se requiere adelantar los resultados a los que se espera arribar, mientras que el grupo o equipo de investigación, directivos académicos, e inclusive la agenda universitaria o programa de desarrollo de la institución o la dependencia, juegan un papel definitorio en todo el proceso de diseño.

Otro aspecto que se presenta en la teoría de agendas públicas y que puede servir de base para fijar una agenda de investigación es el referido a su tipología. Las agendas públicas se clasifican en dos tipos, a saber:

Agendas sistémicas o macro: incluye la más amplia gama de posibilidades de problemas que pueden ser objeto de medidas por parte del gobierno y que podría ser colocada en la agenda pública.

Agendas institucionales o micro: se incluyen aquellos temas que son ya la consideración de los tomadores de decisiones, las legislaturas o tribunales (Puentes-Markides, 2007).

En el caso de las agendas de investigación, éstas también pueden ser clasificadas de igual forma; es decir, se pueden fijar agendas a nivel macro, como por ejemplo las que se diseñan en el ámbito gubernamental en sectores como el de educación o el de ciencia, investigación y desarrollo. En tanto, las de tipo institucional o micro pueden presentarse en las universidades, facultades, institutos, departamentos, grupos o equipos de investigación; estas últimas, circunscritas a áreas específicas del conocimiento, como es el caso de la tratada en este trabajo. 


\section{EL DISEÑO DE AGENDAS DE INVESTIGACIÓN}

Cuando se observan los logros obtenidos en las instituciones dedicadas a la investigación y el desarrollo científico a través de la consulta de sus informes periódicos, en la mayoría de ellos, resulta notoria la ausencia de una agenda de investigación explícitamente estructurada que guíe la obtención de sus resultados, lo que contribuye a que, por lo general, el diseño de los proyectos y actividades de investigación partan de la iniciativa individual de los investigadores y en el mejor de los casos, a falta de una agenda estructurada, tomen como marco de forma indirecta al programa de desarrollo de la dependencia o institución en la cual se insertan, con el inconveniente de que muchos de estos programas han sido diseñados de forma institucional sin tomar en cuenta los criterios del personal que realiza directamente la investigación. A este comportamiento habría que añadir que muchos proyectos de investigación que se desarrollan adolecen del tan mencionado vínculo con la práctica histórico-social y el desarrollo tecnológico, además de su marcada naturaleza individual y, por consiguiente, falta de colaboración en su planificación estratégica.

Este último aspecto pudiera encontrar solución si se parte del criterio de que "las agendas de investigación académicas constituyen un eslabón clave en las relaciones de investigación y sociedad y también, por tanto, entre tecnología y sociedad" (Sutz, 2005: 111). Mientras que, en lo referente a la colaboración, esta autora señala que "desde una perspectiva normativa las agendas de investigación en contextos periféricos deberían tener la brújula apuntando hacia la colaboración con los esfuerzos por superar el subdesarrollo. Esto exige el concurso de todas las orientaciones disciplinarias [...]" y agrega que "el centro de la cuestión se ubica en el término colaboración: ¿Colaborar con quién? ¿Colaborar en torno a qué?, lo que equivale a plantear que las agendas de investigación incorporen a su formulación demandas que se generan en el ámbito social, en el sentido más amplio del término" (Sutz, 2005: 112). 
La falta de comprensión sobre lo anterior conlleva al desconocimiento de la dimensión que toma este tipo de agenda en la práctica y cultura investigativa contemporáneas, en la que las formas antiguas del quehacer científico han sido reemplazadas por las actuales estrategias de planificación más dinámicas e interactivas, panorama en el cual la agenda de investigación toma un lugar protagónico en la logística organizativa de instituciones y dependencias de investigación y desarrollo, encargadas de la generación del nuevo conocimiento. "En términos muy generales puede decirse que las agendas de investigación se van configurando en torno a tradiciones cognitivas, al reconocimiento de nuevas avenidas en campos específicos, a diversos factores de legitimación del trabajo académico, a los recursos disponibles 'libres' y a las políticas de las agencias de financiamiento de la investigación" (Sutz, 2005:112).

Estas nuevas formas de organización del quehacer científico han motivado que estudiosos de la ciencia centren su atención en las agendas de investigación como objeto de estudio, generando así conocimiento teórico, aunque todavía de manera incipiente, sobre su definición, sentido, objetivos, características y tipología. Varios han sido los autores que, en su afán por definir agendas de investigación en sus campos de conocimiento, han aportado definiciones sobre este tipo de agendas, tales como los que se mencionan en la introducción de este trabajo y entre los que se pueden tomar como referencia oportuna, asociada a la transformación universitaria, la propuesta por Muro-Lozada y Serrón (2007: 13-14), quienes en términos generales la definen a partir de los rasgos siguientes:

- Es una interrogante que admite respuestas múltiples.

- Es una estrategia que parte del reconocimiento de capital de saberes existentes en la institución.

- Es una plataforma para el rescate de la racionalidad dialógica, la medición reflexiva de sus actores acerca del impacto y trascendencia de sus acciones. 
Agendas de Investigación en Bibliotecología...

- Es un proceso igualmente asociado a la idea de cambio planeado, direccionado y revalorizado que les permite a los miembros de la organización la reconstrucción de los saberes desde la integración de viejas y nuevas prácticas para el fortalecimiento y el desarrollo de la institución.

El trabajo de estos autores, junto al citado anteriormente de Sutz (2005), constituye uno de los más completos en aportaciones teóricas sobre las agendas de investigación que se han publicado en español, y aporta un conjunto de definiciones, enfoques y objetivos de obligada consulta sobre el tema, al tiempo que señala que, dentro de los aspectos que le dan sentido a la definición de una agenda de investigación, se pueden mencionar los siguientes:

- Rescata el sentido y compromiso social.

- Supera el aislamiento y la desarticulación.

- Da organicidad a problemas y oportunidades.

- Evita la repetición de rutinas preestablecidas.

- Responde a requerimientos específicos para establecer vínculos estrechos con instituciones, impulsar el financiamiento de los proyectos y fortalecer la cultura investigativa.

Otra de las aportaciones de Muro-Lozada y Serrón (2007) radica en la definición de los objetivos estratégicos que debe tener una agenda orientada a la investigación en el área de educación, los cuales contienen acciones que bien pudieran ser consideradas como generales para una agenda de investigación definida en cualquier campo del conocimiento y entre los que pudieran figurar los siguientes:

- Concebir la investigación como un proceso social.

- Conjugar necesidades e intereses personales, grupales, institucionales y sociales como una vía para darle respuesta, desde una perspectiva crítica, a la problemática. 
- Vincular la investigación al desarrollo sustentable como proceso continuo y cuyo impacto se evaluará a nivel de beneficios tangibles y cuantificables.

- Contribuir al fortalecimiento de la cultura investigativa.

- Proporcionar respuestas planificadas, concertadas y coordinadas.

- Identificar áreas de conocimiento que requieran investigaciones adicionales.

- Impulsar el financiamiento de los proyectos de investigación sobre la base de ciertas debilidades del sistema de conocimientos.

- Proporcionar a las autoridades académicas información pertinente y contextualizada sobre las prioridades y necesidades de investigación (Muro-Lozada y Serrón, 2007: 16).

El cumplimiento de muchos de estos objetivos se asocia a la propia naturaleza de la agenda de investigación, en la que se pueden identificar, según Castellanos-Domínguez, Torres-Piñeros y Domínguez-Karen Patricia (2009:129), dos características principales:

- Como articuladora de oferta y demanda de conocimiento.

- Como visión prospectiva.

La primera característica indica que el diseño de una agenda de investigación debe estar orientado a satisfacer las necesidades de conocimiento de la sociedad o sector productivo o de servicio con el que se vincule, así como las demandas existentes para esclarecer y fortalecer el desarrollo de las ideas, teorías y conceptos en el campo disciplinar que comprende. En este sentido, una agenda de investigación sobre el tema aquí tratado deberá aportar, con la solución de sus problemas, nuevo conocimiento que satisfaga las necesidades para la toma de decisiones en materia de política científica y de la información, inteligencia competitiva, vigilancia científica y tecnológica, entre otras. Mientras que, de acuerdo con la segunda característica, esta agenda deberá consti- 
tuirse en un instrumento que oriente de forma prospectiva sobre las últimas tendencias que marcan el desarrollo teórico-disciplinar, la práctica social y los principales frentes de investigación en el campo de conocimiento del que trata la agenda.

Lo anterior conlleva a que, para poder identificar los elementos constitutivos de una agenda de investigación en determinado campo de conocimiento, será necesario no sólo conocer bien a fondo el alcance, las delimitaciones y las relaciones y tendencias del desarrollo teórico-disciplinar del campo que se pretenda incluir en la agenda, sino que también se deberán identificar y dominar las áreas, sectores o servicios de la práctica social a la que vayan orientados los resultados obtenidos, motivo por el cual, a continuación, para poder identificar los elementos constitutivos que se deben tener en cuenta en una agenda de investigación en el tema tratado, se identifican previamente: el desarrollo teóricodisciplinar del área de investigación en cuestión, los principales enfoques metodológicos, la orientación de sus resultados en la práctica social, y las tendencias y principales frentes de investigación de esta área de investigación.

\section{DESARROLLO Y TENDENCIAS}

DE LAS INVESTIGACIONES MÉTRICAS DE

\section{LA INFORMACIÓN Y DEL CONOCIMIENTO CIENTÍFICO}

El crecimiento acelerado de las investigaciones relacionadas con la Metría de la Información y del Conocimiento Científico (MICC) se asocia, en lo fundamental, a la existencia de dos fenómenos colaterales a su propio desarrollo: el referido a la acelerada informatización y digitalización de la literatura científica en las últimas décadas, y el referido al proceso de matematización de la información y del conocimiento científico. El primero se relaciona con la urgencia de procesar, almacenar, recuperar y difundir el flujo de información generado de forma exponencial, mientras que el segundo parte de los requerimientos de la sociedad y en particu- 
lar de determinados grupos sociales (comunidades académicas, profesionales bibliotecarios y de la información, políticos científicos, innovadores, tecnólogos, entre otros) de medir y evaluar, cada vez con mayor énfasis y precisión, las regularidades presentes en los procesos de producción y comunicación científica.

Este comportamiento, todavía en franco desarrollo, ha propiciado el crecimiento y consolidación de un corpus de conocimiento sobre un conjunto de teorías y especialidades métricas, así como una extensa variedad de enfoques metodológicos y formas de abordar este tipo de investigaciones, cuyos resultados han sido introducidos en la práctica histórico-social a través de la toma de decisiones en materia de política científica y de información.

\section{El desarrollo teórico-disciplinar}

El Estudio Métrico de la Información y del Conocimiento Científico, como campo de investigación emergente y de frontera de las Ciencias Bibliotecológica y de la Información, ha tenido un desarrollo acelerado en los últimos tiempos, lo cual se debe a su naturaleza multi, inter y transdiciplinaria. Esta característica ha propiciado el surgimiento de una muy variada gama de especialidades métricas y enfoques metodológicos proveniente de diferentes sistemas de conocimiento.

Durante el desarrollo alcanzado en este tipo de estudio se ha puesto a prueba la factibilidad del uso de teorías, métodos, modelos e indicadores cuantitativos utilizados en la identificación de las regularidades de la producción y comunicación científica en muy diversas áreas temáticas y regiones, así como las reveladas en los sistemas bibliotecarios y de la información. Estos resultados han aportado información muy valiosa para la toma de decisiones en los Sistemas de Gestión de Información, lo que constituye, en estos últimos, una herramienta novedosa de evaluación para su organización y planificación.

El campo de los Estudios Métricos de la Información y del Conocimiento Científico es resultado de la interacción de diversos métodos y modelos matemáticos y estadísticos con las disciplinas 
que integran el denominado Sistema de Conocimientos Bibliológico-Informativos (Bibliotecología, Bibliografología, Archivología y Ciencia de la Información) (Setién-Quesada y Gorbea-Portal, 1994). A esta interacción se le atribuye el surgimiento de un conjunto de especialidades métricas: la Bibliotecometría, propuesta en 1948 por Ranganathan (1969); la Bibliometría (Pritchard, 1969); la Informetría, definida en 1979 por Nacke (1983) y la Archivometría (Gorbea Portal, 1994 y 2005). La conformación del campo se completa con especialidades métricas pertenecientes a otros sistemas de conocimiento, como la Cienciología, propuesta por Znaniecki en 1925 y por Ossowski en 1935, que fue denominada desde 1963 como Ciencia de la Ciencia por Price (1973) y por Dobrov en 1966; la Cienciometría de Nalimov Mucsenko en 1969; y la Sociometría (Moreno, 1951); la Tecnometría (MeyerKrahmer y Reiss, 1992; Grupp, 1994); la Cienciometría desarrollada por Nalimov Mucsenko en 1969, y la Webmetría, propuesta por Abraham en 1996 y retomada por Almind e Ingwersen en 1997. Muchas de las especialidades métricas mencionadas han alcanzado cierta notoriedad en esta comunidad epistémica en los últimos veinte años, lo cual se ha visto reflejado en la creciente generación de literatura especializada sobre estos tópicos, como en el caso de la Bibliometría, la Informetría y la Cienciometría.

Toda esta diversidad terminológica y disciplinar ha sido integrada en un modelo teórico sobre el Estudio Métrico de la Información Documental (Gorbea Portal, 1994 y 2005) y más tarde ampliado con la creación del Área de Investigación en el entonces Centro Universitario de Investigaciones Bibliotecológicas (CUIB, UNAM), denominada como Metría de la Información y del Conocimiento Científico (Gorbea Portal y Russell Barnard, 2010).

En un artículo reciente, Milojevic y Leydesdorff comprueban que la Bibliometría, Cienciometría, Informetría y Webmetría pueden ser consideradas como manifestaciones de una sola área de investigación con similares objetivos y métodos, la cual denominan como Métricas o Metría de la Información (iMetrics) (Milojevic y Leydesdorff, 2012). Este estudio explora la distinción cognitiva y social de este campo de conocimientos en relación 
con la Ciencia de la Información (Information Science, IS), para finalmente concluir que el volumen de publicaciones pertenecientes al iMetrics ha aumentado rápidamente durante la última década. Además, estos autores identifican un núcleo de investigadores que predominantemente se centran en este campo de conocimiento, en los cuales se observa la alta similitud del vocabulario utilizado en los títulos y la base de conocimiento que comparten, además de aseverar que este frente de investigación avanza más rápido que el de la investigación sobre Ciencia de la información en general, hallazgo que, al decir de estos autores, se acerca más al "sueño" de Price.

En el modelo teórico-disciplinar de la Figura 1 se integra el conjunto de teorías, enfoques y especialidades métricas identificadas en dos dimensiones cartesianas: la primera en el eje de las "Y", representada por el Campo de Conocimientos; y la segunda en el eje de las "X", por el Área de Investigación. La definición de estos dos elementos constitutivos en el diseño de una agenda de investigación, así como el entorno disciplinar en el que convergen, resultan de vital importancia, debido a que permiten establecer la delimitación y alcance teórico-conceptual que servirá de marco para el diseño de la agenda.

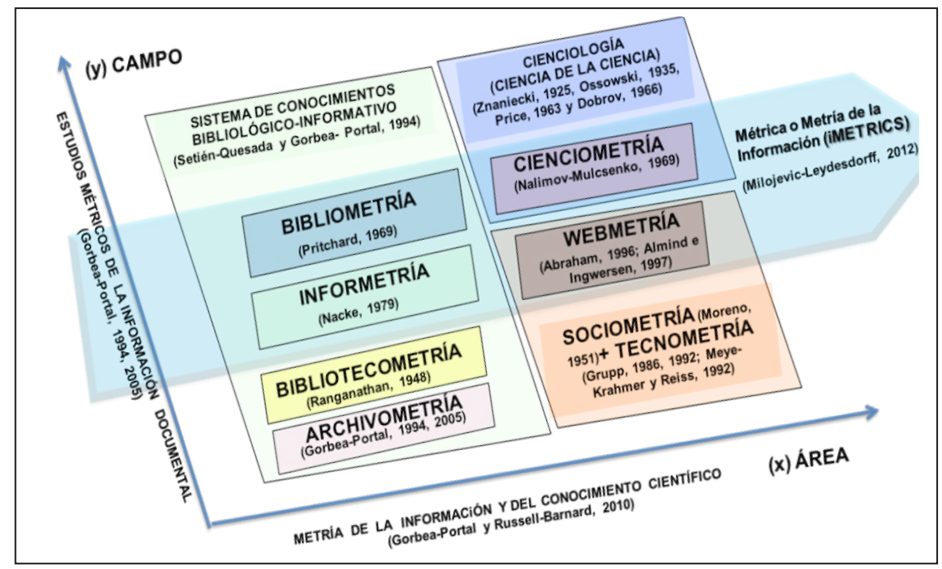

Figura 1: Modelo teórico-disciplinar de la Metría de la Información y del Conocimiento Científico. 


\section{Los enfoques metodológicos}

Otro de los aspectos a considerar en la conformación y delimitación de este campo viene dado por la diversidad de enfoques que pueden ser utilizados en las investigaciones que se realizan, variedad que radica en el carácter transdisciplinario de los problemas que se solucionan en este tipo de investigaciones, así como en la naturaleza de sus objetos de estudio, entre los enfoques teórico-metodológicos que más se distinguen, se destacan por su generalización, los siguientes:

- La Teoría sobre el Flujo de Información Documental.

- La Teoría de Sistemas.

- El Principio de Historicidad de la Ciencia.

- La Teoría de la Comunicación Científica.

- El Ciclo Social en la Generación del Conocimiento Científico.

- El proceso de Matematización de la Ciencia y de la Información.

- El fenómeno de Integración-Diferenciación de la Ciencia.

Muchos de estos enfoques provienen de disciplinas diferentes; sin embargo, alcanzan su verdadera comprobación en este tipo de investigaciones, como por ejemplo la Teoría de Sistemas, de la Comunicación Científica y el Principio de Historicidad de la Ciencia, entre otros.

La implementación de los resultados en la práctica histórico-social

Como quedó indicado anteriormente, las agendas de investigación académicas constituyen un eslabón clave en las relaciones entre la investigación y la sociedad; es por ello que se requiere tener bien definidos los campos o sectores hacia los que se deben orientar los resultados, orientación que deberá estar condicionada por los propósitos generales de cada problema o proyecto de investigación. 
Entre los principales campos o sectores a los que podrían ir orientados los resultados de una agenda de investigación en Metría de la Información y del Conocimiento Científico se encuentran los siguientes:

- Política Científica y de Información.

- Industria Editorial y de Contenido.

- Inteligencia Competitiva.

- Vigilancia Tecnológica.

- Evaluación y Ranking de Instituciones, Dependencias, Comunidades Académicas, Recursos y Fuentes de Información.

Los mecanismos de instrumentación de resultados en la práctica social pueden ser muy variados; hay autores que sostienen el criterio de que una forma de aplicación directa de los resultados de este tipo de estudios en la gestión de la investigación y la política científica puede ser canalizada mediante la creación de Unidades Bibliométrica en la estructura universitaria, como es el caso de las universidades de Navarra y Granada, en España (Torres Salinas y Jiménez Contreras, 2012). Criterio que los autores de estas líneas suscriben, por ser las instituciones de educación superior las principales generadoras de conocimiento, y por consiguiente, las que más requieren de constantes procesos de evaluación de lo que producen, y del presupuesto que invierten en sus gestiones.

En este mismo entorno universitario, se ha fundamentado también el efecto potencial que ha provocado la implementación de la práctica bibliométrica en la biblioteca académica; en este sentido se alude a que la institucionalización de esta práctica puede tener un efecto potencial sobre el papel de la biblioteca académica y de sus bibliotecarios, así como de su relación con el contexto más inmediato, la organización de la universidad (Aström y Hansson, 2012).

Otras formas de instrumentación práctica de los resultados obtenidos en este tipo de investigaciones han sido empleadas históricamente por grandes sistemas de información a través de 
sus sistemas de indicadores, como ha sido el caso del Journal Citation Reports (JCR) administrado en la actualidad por Thomson Reuters, el Sistema Scopus de Elsevier y más recientemente el Google Scholar Metric, de este importante motor de búsque$\mathrm{da}$, aunque ha sido criticado por su inmadurez y limitaciones, al mismo tiempo que se le reconoce de manera positiva por el desembarco de Google en el ámbito bibliométrico (Delgado López Cózar y Cabezas Clavijo, 2012).

Principales tendencias y frentes de investigación

Uno de los desafíos que debe enfrentar la investigación relacionada con la Metría de la Información y del Conocimiento Científico, en la intención de vincular sus resultados con la práctica histórico-social, se centra en la identificación de las principales tendencias y frentes de investigación más activos y de mayor demanda en los sectores productivos y de servicio a los que se orientan los resultados de este tipo de investigación; entre las tendencias más identificadas en la literatura especializada se pueden mencionar las siguientes:

Bibliometría Evaluativa: evaluación de Instituciones Científicas y de Educación Superior, de Recursos Humanos, de fuentes y recursos, entre otros (Ranking de Instituciones, de Revistas Científicas y de Plataformas y Contenidos Digitales en la Red, Visibilidad e Impacto).

Teoría de la Evaluación y de la Generación de Indicadores Científicos: Redes y Sistemas de Indicadores, Atlas de la Ciencia.

Descubrimiento de Conocimiento en Repositorios de Datos: identificación de patrones de comportamiento de la información, mediante los procesos de Minería de Datos y de Textos.

Visualización de la Información: conversión de datos en información mediante técnicas de visualización.

Redes sociales: representación de Redes de Autores, Citas, Detección de Colegios Invisibles y de Redes de Colaboración. 
En este sentido, mientras mayor claridad y precisión se tenga en la identificación de tendencias y frentes de investigación, mejor vinculación y orientación de los resultados, y mayor impacto y visibilidad alcanzarán los actores y el conocimiento obtenido en la solución de los problemas que se integren en la agenda.

\section{ELEMENTOS CONSTITUTIVOS PARA EL DISEÑO DE UNA AGENDA DE INVESTIGACIÓN EN EL ÁREA DE LA METRÍA DE LA INFORMACIÓN Y DEL CONOCIMIENTO CIENTÍ́fICO}

Para la identificación de los elementos constitutivos que deben conformar la agenda de investigación en esta Área, se parte de un núcleo básico que la define y caracteriza, en el cual, según autores como Muro-Lozada y Serrón (2007:14), deben considerarse los aspectos siguientes: "la noción de red de problemas, de grupos de investigación, y de recursos. Para ello la agenda establecerá campos, áreas, líneas y proyectos de acción que atiendan demandas específicas del contexto, enmarcados en un proceso de negociación entre los actores involucrados."

A los elementos anteriores se les pueden agregar los temas de estudio vinculados con las líneas, las especialidades básicas que sirven de sustento teórico para el desarrollo de las líneas, las especialidades transdisciplinarias que permiten la inclusión de otros métodos, técnicas y procesos que contribuyan a la solución de los problemas, la definición del o los problemas o metaproblemas para los cuales se diseña el proyecto de investigación, así como la representación de un mapa de conocimientos en el cual se incluyen todos los elementos que constituyen la agenda e incluso la orientación de los resultados que se esperan obtener como consecuencia de la ejecución de la agenda diseñada. 
Definición del Campo de investigación: los Estudios Métricos de la Información y del Conocimiento Científico

Campo eminentemente transdisciplinario que surge de la intersección de métodos y modelos matemáticos y estadísticos con disciplinas pertenecientes a las Ciencias Bibliotecológica y de la Información, a la Cienciología o Ciencia de la Ciencia, asi como con otras especialidades métricas como la Sociometría y la Tecnometría; comprende un conjunto de especialidades métricas integrado por la Bibliometría (Descriptiva, Evaluativa e Histórica), la Bibliotecometría, la Archivometría, la Informetría, la Cienciometría y la Webmetría. Orientados a identificar el comportamiento cuantitativo de fenómenos propios del Ciclo Social de la Información y de la Producción del Conocimiento Científico.

\section{Definición del Área de Investigación:}

Metría de la Información

y del Conocimiento Científico

Las áreas de investigación pueden ser concebidas como una estructura que permite la organización de la actividad investigativa en las universidades y sus dependencias docentes y de investigación, en la cual se organizan actividades y proyectos distribuidos por las líneas que la conforman. Estas áreas propician el trabajo colaborativo y la definición de líneas y proyectos de forma conjunta entre los investigadores que la integran. Morales de Mosquera (2001: 28) la define como: "Unidad temática del conocimiento de carácter general de la cual se derivan líneas de investigación".

La definición o alcance del área de investigación sobre la Metría de la Información y del Conocimiento Científico puede quedar como sigue:

Indaga el comportamiento de las regularidades presentes en los procesos de producción y comunicación científica, la evalua- 
ción de los recursos, fuentes, fondos y servicios de información, y también la de los sistemas científicos, mediante la utilización de métodos y modelos matemáticos e indicadores científicos.

Líneas de investigación

Quizás por constituir la forma de organización básica y elemental de la indagación científica en las instituciones de investigación y desarrollo, este concepto sea uno de los más definidos en la literatura especializada, varios han sido los autores que le atribuyen cualidades tales como: "subsistemas estratégicos organizativos, guías para la acción, estrategia que permite diagnosticar una problemática, eje ordenador de la actividad de investigación, conjunción de esfuerzos en forma ordenada y sistemática de carácter institucional y académico", entre otras (Puertas de García, 2002; citada por Agudelo Cely, 2004).

Otra definición que por su nivel de especificidad amplía la conceptualización de la línea de investigación es la de Morales de Mosquera (2001:28) quien la define como: "Conjunto de proyectos que busca resolver o avanzar en la solución de un problema dentro de determinada área. Tiende a resolver un problema macro, haciéndolo por etapas para definir en cada una de ellas un tópico específico o parcial, hasta lograr que la suma de los resultados obtenidos en estas etapas consolide o aporte a la solución del problema planteado."

De acuerdo con los conceptos anteriores y en el afán de identificar alguna de las líneas de investigación que se pudieran integrar en esta área de investigación, en la Tabla 1 se especifican cuatro líneas con sus contenidos o temas de estudio, sin el ánimo de pretender que sean las únicas que pudieran definirse en esta área de investigación. 
Agendas de Investigación en Bibliotecología...

Tabla 1

\begin{tabular}{|c|l|}
\hline \multicolumn{2}{|c|}{ Distribución de líneas de investigación, según contenidos y temas de estudio que cubren. } \\
\hline \multicolumn{1}{|c|}{ LíNEAS DE INVESTIGACIÓN } & \multicolumn{1}{c|}{ CONTENIDOS Y TEMAS DE ESTUDIO QUE CUBREN } \\
\hline $\begin{array}{l}\text { 1. Identificación de regularidades biblio- } \\
\text { métricas e informétricas en el Flujo de } \\
\text { Información Documental (FID). }\end{array}$ & $\begin{array}{l}\text { Aplicación de métodos y modelos matemáticos clásicos de la } \\
\text { Bibliometría y la Informetría en la identificación de regularidades } \\
\text { cuantitativas en el FID. }\end{array}$ \\
\hline $\begin{array}{l}\text { 2. Comportamiento cienciométrico del } \\
\text { Ciclo Social de la Producción del cono- } \\
\text { cimiento científico. }\end{array}$ & $\begin{array}{l}\text { Estudios sobre el comportamiento cienciométrico del Ciclo Social } \\
\text { de la Producción del conocimiento científico, mediante las redes } \\
\text { de colaboración y comunicación científica entre comunidades, } \\
\text { instituciones, países, entre otras. }\end{array}$ \\
\hline $\begin{array}{l}\text { 3. Modelos bibliotecométricos y archivo- } \\
\text { métricos en la evaluación cuantitativa } \\
\text { de sistemas bibliotecarios y de la } \\
\text { información. }\end{array}$ & $\begin{array}{l}\text { Evaluación cuantitativa de fondos, fuentes y servicios biblioteca- } \\
\text { rios, archivísticos y de información con el propósito de identificar } \\
\text { el comportamiento bibliométrico o archivométrico en estos } \\
\text { sistemas. }\end{array}$ \\
\hline $\begin{array}{l}\text { 4. Descubrimiento de conocimiento en } \\
\text { repositorios de datos y recursos de } \\
\text { información. }\end{array}$ & $\begin{array}{l}\text { Identificación de patrones de conocimiento en repositorios de } \\
\text { datos y recursos de información mediante el uso de procesos } \\
\text { tales como la Minería de Datos, de Texto, la Bibliominería, la We- } \\
\text { bmetría, el oLAP (Procesamiento Analítico en Línea), entre otros. }\end{array}$ \\
\hline
\end{tabular}

\section{Temas de estudio}

Para el desarrollo de estas líneas de investigación se requiere involucrar un conjunto de Temas de Estudio que aporten, de acuerdo con los propósitos y contenidos de la línea, de manera más precisa los métodos, conceptos, indicadores, modelos matemáticos y estadísticos y las herramientas requeridas para el desarrollo de los proyectos y solución de los problemas contenidos en cada una de las líneas. En relación con las líneas de investigación antes definidas, se pueden asociar los siguientes temas de estudio:

- Comunicación Científica. Impacto y visibilidad de la información.

- Producción Científica. Productividad Científica y relaciones de autoría.

- Colaboración Científica.

- Evaluación de Recursos, Fuentes, Fondos y Servicios de Información.

- Evaluación de la Ciencia y de los Sistemas Científicos. 
Para el desarrollo de estos temas de estudio, que se vinculan a las líneas antes definidas, se requiere la intervención de especialidades métricas consideradas como básicas en el sistema de conocimientos de este campo, así como otras de carácter transdisciplinario que permitan su estudio desde los diferentes enfoques; es decir, multi, inter y transdisciplinario, sin que para ello se pierda el alcance y delimitación del campo, del área y de las líneas que se definen.

Especialidades involucradas

Las especialidades métricas que aportan las bases teóricas para el estudio de los temas anteriores, así como las transdisciplinarias, de las que se obtienen los métodos y procesos para la identificación de nuevo conocimiento en los repositorios de datos, se muestran en la Tabla 2.

Tabla 2

\begin{tabular}{|l|l|}
\hline \multicolumn{2}{|c|}{$\begin{array}{c}\text { Distribución de especialidades básicas y } \\
\text { Información y }\end{array}$ del Conocimiento Científico } \\
\hline \multicolumn{1}{|c|}{ Especialidades Básicas } & \multicolumn{1}{c|}{ Especialidades transdisciplinarias } \\
\hline Bibliometría & KDD (Descubrimiento de Conocimiento en Bases de Datos) \\
\hline Informetría & OLAP (Procesamiento Analítico en Línea) \\
\hline Bibliotecometría & Minería de Datos \\
\hline Archivometría & Minería de Texto \\
\hline Cienciometría & Bibliominería \\
\hline Webmetría & Redes Sociales \\
\hline $\begin{array}{l}\text { Teoría de la Evaluación y de los Indicadores } \\
\text { Científicos }\end{array}$ & Visualización de la Información \\
\hline
\end{tabular}

Mapa de conocimiento

La construcción de mapas y otras representaciones gráficas tiene la finalidad de poder visualizar estructuras de relaciones sumamente complejas y son instrumentos de apoyo para la gestión del 
conocimiento y para la toma de decisiones de una organización o de un sector. Las relaciones de conocimiento que se establecen entre las líneas, temas de estudio, especialidades métricas y especialidades transdisciplinarias, así como la orientación a la que se destinan los resultados de investigación, pueden ser representados en un mapa de conocimiento, tal y como se muestra en la Figura 2. De especial importancia se destacan las relaciones entre las líneas de investigación y los temas de estudio que en un momento determinado son prioritarios para la institución, sobre todo en el aspecto de la resolución de problemas sociales.

Destaca también la dinámica inherente en este tipo de mapas debido al avance propio del área de conocimiento, cambios en los temas preferenciales, el desarrollo acelerado de las herramientas y metodologías de estudio, así como la influencia de elementos transdisciplinarios, aspectos que han sido tratados en la literatura especializada y en particular la referida al uso de la metodología de mapeo en la representación de conocimiento de los grupos de investigación (Falk-Krzesinski, Holly J. et al. (2011). 
La Metría de la Información y del Conocimiento Científico...

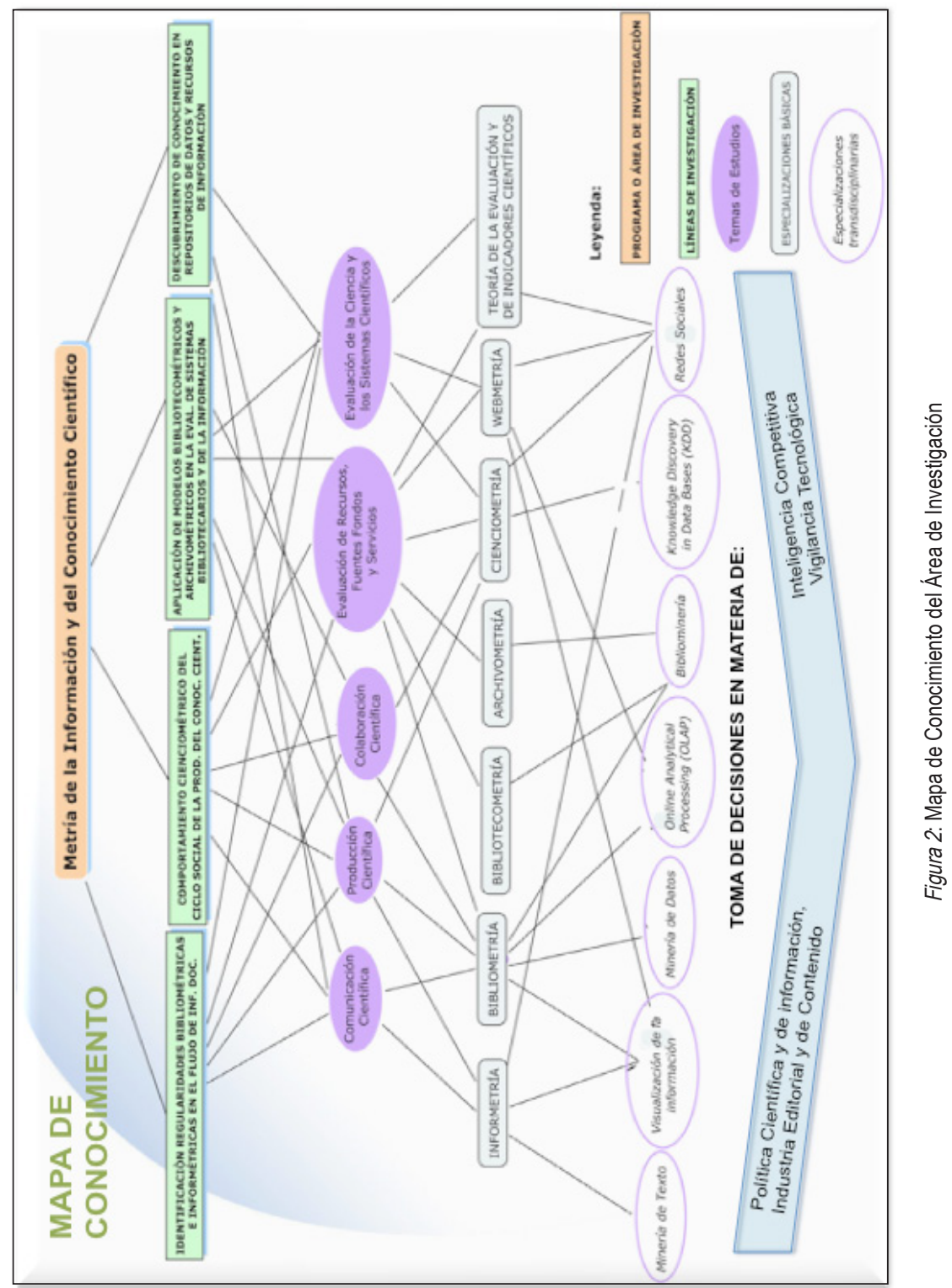




\section{CONSIDERACIONES FINALES}

El diseño y definición de agendas de investigación en universidades, institutos, áreas y grupos de investigación garantizan la organización de las actividades de investigación, al tiempo que facilitan la distribución y optimización de los recursos humanos y financieros dedicados a estas actividades, así como la vinculación e introducción de sus resultados en la práctica social.

Las actuales relaciones de inter y transdisciplinariedad que se dan en los procesos de reconstrucción de saberes y generación del nuevo conocimiento exigen, cada vez más, del diseño de agendas de investigación en las que se articulen de manera determinante contenidos, metodologías, técnicas y disciplinas de otros campos requeridos en la solución de problemas complejos de investigación, en particular en áreas que por su naturaleza lo requieren para obtener sus resultados de investigación.

Resulta necesario mejorar el entendimiento y reconocimiento de la Metría de la Información y del Conocimiento Científico como un área de investigación indispensable que aporta nuevo conocimiento para la gestión y evaluación del trabajo académico y de información en las universidades; la institucionalización de este tipo de investigaciones en la estructura universitaria podría constituir un buen inicio.

Los elementos constitutivos que aquí se presentan como sugerencia para el diseño de una agenda de investigación en este campo temático garantizan, en cierta medida, la generación de conocimiento necesario para la solución de los problemas más acuciantes y actuales relacionados con la Metría y Evaluación de la Información y el Conocimiento Científico, y con ello, la toma de decisiones en materia de política científica y de información en el ámbito institucional, sectorial, nacional e internacional. 
La Metría de la Información y del Conocimiento Científico...

\section{REFERENCIAS BIBLIOGRÁFICAS}

AGARD (Advisory Group for Aerospace Research \& Development) (1992), A Research Agenda for Scientific and Technical Information, AGARD ADVISORY REPORT 316 Report of a Workshop held in Lisbon, Portugal, on 7th-9th April, 1992, by the Technical Information Panel of AGARD.

Agudelo Cely, Nubia (2004), "Las líneas de investigación y la formación de investigadores: una mirada desde la administración y sus procesos formativos", en Revista ieRed: Revista Electrónica de la Red de Investigación Educativa [en línea], Vol.1, Núm. 1 (JulioDiciembre), disponible en: http://revista.iered.org (consultado el 5 de noviembre de 2012).

Aström, Federik and Joacim Hansson (2012), "How implementation of bibliometrics practice affects the role of academic libraries", en:JournalofLibrarianshipan Information Science(On line version), http:// lis.sagepub.com/content/early/2012/09/11/0961000612456867.citation (consultado el 5 de noviembre de 2012).

Baumgartner, Frank R. and Bryan Jones (1993), Agendas and Instability in American Politics. Chicago: University of Chicago Press.

Castellanos Domínguez, Oscar Fernando; Luz Marina Torres Piñeros y Karen Patricia Domínguez (2009), Manual metodológico para la definición de agendas de investigación y desarrollo tecnológico en cadenas productivas agroindustriales, Bogotá, D.C.: Giro Editores Ltda., $146 \mathrm{p}$.

Cuadra Associates (1982), A Library and Information Science Research Agenda for the 1980s: Summary Report (Dept. of Education, Office of Libraries and Learning Technologies, Project No. 300-81-0022), Santa Mónica, Calif.: Cuadra Associates, Inc. 
Curran, Charles (1991), Impact of National Research Agendas on LIS Research (Chapter three) pp. 31-44, en Library and Information Science Research: Perspectives and Strategies for Improvement / edited by McClure, Charles R. y Peter Hernon,-New Jersey: Ablex Publishing Corporation, 230 p.

Delgado-López-Cózar, Emilio y Álvaro Cabezas-Clavijo (2012), “Google Scholar Metrics: Una herramienta poco fiable para la evaluación de revistas científicas", en El Profesional de la Información, Vol. 21, Núm. 4, agosto.

Eustis, Joanne D. (2000), Agenda Setting the Universal Service Case, Faculty of the Virginia Polytechnic Institute and State University (Dissertation Doctor of Philosophy in Environmental Design and Planning), $286 \mathrm{p}$.

Falk-Krzesinski, Holly J. et al. (2011), "Mapping a research agenda for the science of team science", en Research Evaluation, Vol. 20, Núm. 2, pp. 145-158.

Fitzgibbons, Shirley Grinnell (1984), "Funding of Research in Librarianship", en Library Trends, Spring, pp. 537-556.

Galaz Fontes, Jesús Francisco (1999), "Notas para una agenda de investigación sobre el académico en la educación superior mexicana”, en Sociológica, año 14, Núm. 41, pp. 1-25, septiembre-diciembre.

Gorbea-Portal, S. (1994), "Principios teóricos y metodológicos de los estudios métricos de la información”, en Investigación Bibliotecológica (México) 8(17): 23-32, julio-diciembre.

— — - (2005), Modelo teórico para el estudio métrico de la información documental, Gijón: TREA, 171 p. 
_ - -; Jane Russell Barnard (2010), Seminario Permanente de Investigación, Centro Universitario de Investigaciones Bibliotecológicas, UNAM, 4 hrs.

Grupp, Hariolf (1994), "The measurement of technical performance of innovations by technometrics and its impact on established technology indicators", en Research Policy, 23: 175-193.

Hernon, Peter and Candy Schwartz (2008), "Leadership: Developing a research agenda for academic libraries", en Library \& Information Science Research, 30: 243-249.

Li Pun, Hugo y Víctor M. Mares (2000), "Una agenda de investigación para el cambio", en CONDESAN 21: Perspectivas de CONDESAN al siglo XXI, pp. 1-7 (consultado el 19 de septiembre de 2012).

Kingdon, John W. (1995), Agendas, Alternatives, and Public Policy, 2nd ed. New York: Harper Collins College Publishers.

McClure, Charles R. y Peter Hernon (Eds.) (1991), Library and Information Science Research: Perspectives and Strategies for Improvement, New Jersey: Ablex Publishing Corporation, 230 p.

Meyer-Krahmer, Frieder y Thomas Reiss (1992), "Ex ante evaluation and technology assessment - two emerging elements of technology policy evaluation", en Research Evaluation 2(1): 47-54.

Milojevic, Stasa and Loet Leydesdorff (2012), "Information Metrics (iMetrics): A research Specialty with a Socio-Cognitive Identity?", en Scientometrics, (Online First Article) DOI 10.1007/s11192-0120861-z.

Morales de Mosquera, Luz Yolanda (2001), "Definición de las áreas y líneas de investigación de la Facultad de Ingeniería de la Universidad Militar 'Nueva Granada', en Ciencia e Ingeniería Neogranadina, Julio, 27-32. 
Moreles Vázquez, Jaime (2009), "Uso de la investigación social y educativa. Recomendaciones para la agenda de investigación”, en Perfiles Educativos, Vol. XXXI, Núm. 124, pp. 93-106.

Moreno, J. L. (1951), Sociometry, Experimental Method and the Science of Society. An Approach to a New Political Orientation, New York: Beacon House Inc., 225 p.

Muro Lozada, Xiomara y Sergio Serrón (2007), "La agenda de investigación en el proceso de transformación de las instituciones de educación superior", en Paradigma, Vol. XXVIII, Núm. 1, pp.7-38, junio.

Nacke, O. (1983), "Informetría: Un nuevo nombre para una nueva disciplina. Definición, estado de la ciencia y principios de desarrollo", en Revista Española de Documentación Científica (Madrid), 6 (3): 183-203.

Price, Derek J. de Solla (1973), Hacia una ciencia de la ciencia, Barcelona: Editorial Ariel, 186 p.

Pritchard, A. (1969), "Statistical Bibliography or Bibliometrics?", en Journal of Documentation (London) 25 (4): 348-349, December.

Puentes-Markides, Cristina (2007), Agenda-Setting. Policy Analysis and Decision Making with Emphasis on Chronic Non-communicable Diseases Bridgetown, Barbados, October 15-17, (Presentación en Power Point).

Puertas de García, M. (2002), Diseño de líneas de investigación en instituciones universitarias, Monografías.com, 7 p., consultado en: http://www.monografías.com/cgibin/search. cgi?query=Puertas\%20de\%20Garc\%EDa\%2C\%202002. 
Ranganathan, S. R. (1969), "Librametry and its scope", en Subject analysis for document finding system. Quantification and librametric studies. Management of traslation service. Indian Statistical Institute (Bangladore, India), Documentation Research Training Centre: Indian Statistical Institute, 1969 (DRTC Annual Seminar, 7, Vol. 1: Papers) (Citado por O. Nacke).

Rochester, Maxine K. y Pertti Vakkari (2003), International Library and Information Science Research: A Comparison of National Trends, Section on Library Theory and Research (IFLA Professional Reports, Núm. 82), 56 p.

Setién Quesada, E. y S. Gorbea Portal (1994), "De la Bibliotecología al Sistema de Conocimientos Científicos Bibliológico-Informativo", en Investigación Bibliotecológica, (México), 8(16): 21-25, enerojunio.

Sutz, Judith (2005), "Sobre agendas de investigación y universidades de desarrollo", en Revista de Estudios Sociales, Núm. 22, pp.107115, diciembre.

Torres-Salinas, Daniel y Evaristo Jiménez-Contreras (2012), "Hacia las unidades de bibliometría en las universidades: Modelo y funciones", en Revista Española de Documentación Científica, Vol.35, Núm. 3, julio septiembre.

Townley, Charles (1990), "ACRL Research Agenda. Prepared by the ACRL Research Committee", en: College and Research Libraries, April: 317-319.

Valdés Ugalde, Francisco (2008), "Gobernanza e instituciones. Propuestas para una agenda de investigación”, en Perfiles Latinoamericanos, Núm. 31, pp.95-119. 
Agendas de Investigación en Bibliotecología...

Young, Tamara V.; Thomas V. Shepley and Mengli Song (2010), "Understanding agenda setting in state educational policy: An application of Kingdon's Multiple streams model to the formation of state reading policy “, en Education Policy Analysis Archives, vol. 18, Núm. 15, en: http://epaa.asu.edu/ojs/article/view/771 (consultado el 20 de septiembre de 2012). 


\title{
El uso de la información y la alfabetización informativa
}

\author{
PATRICIA HERNÁNDEZ SALAZAR \\ Universidad Nacional Autónoma de México
}

\section{INTRODUCCIÓN}

a palabra uso tiene varias acepciones. En la literatura filosófica se entiende como: lo que se hace, un acto humano, una acción que lleva a un resultado (Ferrater Mora, 2001, p. 3619). Al integrar ese significado al término información, tenemos que es lo que se hace con la información, la acción que ejerce un sujeto sobre los recursos de información; cabe profundizar sobre la forma de esta acción y de dichos recursos.

En la mayoría de los textos relacionados con la Alfabetización Informativa (AI) sin importar el tema concreto que se aborde (análisis conceptuales; normas; programas; experiencias; evaluación), aparece como constante la frase uso de la información, así en genérico, por lo que surgen las preguntas: ¿existe una idea clara de lo que implica el uso? ¿Se refiere a manejo de herramientas primarias o secundarias? ¿Uso instrumental o conceptual? ¿Qué elementos conforman este fenómeno? Y por último, ¿el sujeto debe estar consciente de ese usar?

La respuesta a estas preguntas (y a algunas otras que irán surgiendo) se hallará en este capítulo, el cual persigue dos objetivos principales: determinar el significado que tiene el uso de la 
información, y proponer un sentido unívoco de la frase. Se parte de la premisa que la AI debería promover aprendizajes en los sujetos que les permitan utilizar cabalmente cualquier recurso de información.

Para cubrir estos objetivos, en el primer apartado, Noción de uso de la información desde los teóricos de la Alfabetización Informativa, se analizan las definiciones de AI y se delimita el sentido que se le ha dado a la frase dentro de este contexto. Esta intención de dar sentido a la frase dentro de la literatura sobre AI nos llevó a establecer que el Pensamiento crítico y la reflexión son sustantivos para el uso, por lo que la segunda parte abunda sobre este tema.

En la tercera sección, Noción del uso de la información desde los estudiosos del uso/utilización de información, se hace el mismo ejercicio de examinar los conceptos, tomando los aportes de los autores que se han dedicado a estudiar este fenómeno y que siguen la tendencia cognitiva orientada "al sujeto que usa"; en ésta, se percibe el uso como un proceso de pensamiento relacionado con la aprehensión de nueva información, que da como resultado un cambio en la estructura de conocimiento de los sujetos que han usado tal información.

Esta delimitación del significado que debe tener el uso de la información permitirá que el diseño de programas de AI incluya las habilidades necesarias para declarar que un sujeto está alfabetizado informativamente.

\section{NOCIÓN DEL USO DE LA INFORMACIÓN POR LOS TEÓRI- COS DE LA ALFABETIZACIÓN INFORMATIVA}

La lectura y el análisis a profundidad de los conceptos de AI generados por los principales teóricos, nos muestran que la etapa "uso de la información" siempre ha estado presente, incluso en forma explícita; a continuación, se presentan los hallazgos por décadas. 
En el reporte de Zurkowski (1974, h. 6), creador de la frase "uso de la información", aparece ya la idea en su concepto de personas alfabetizadas: "Han aprendido técnicas y habilidades para utilizar el amplio rango de herramientas de información tanto como los recursos primarios para moldear soluciones de información a sus problemas."

Se empieza a delinear aquí uno de los problemas de fondo de la AI, la clasificación de los recursos de información o, en forma genérica, los de la información y la clasificación, según el origen de su autoría, en primarios, secundarios y terciarios. Él lo expresa como herramientas (secundarias) y, puntualmente, recursos primarios.

Zurkowski incluso clasifica la totalidad de las fuentes bibliográficas e institucionales, refiriéndose a la información, en formales e informales, e incluye una amplia variedad de recursos: "Teléfono, televisión, radio, voz humana y acción, periódicos, mapas, viajes, cintas de audio, [...] panfletos gubernamentales, librerías, bibliotecas, campañas políticas; iglesias [...]" (Zurkowski, 1974, h. 1 y 2)

Cabe aquí una primera alerta sobre el uso del concepto AI: ¿se tiene claridad en la diferencia para generar aprendizajes sobre la adecuada explotación de recursos primarios y secundarios? La respuesta es no; se habla de información como un ente genérico, y se infiere que el uso de uno u otro tipo es indistinto; no se diferencian las habilidades para manejar un índice y comprender un artículo de publicación periódica, de aquí que con enunciar la utilización/uso como el fin último del proceso se llega al supuesto de que los sujetos poseen las dos aptitudes.

En la década de los ochenta aparecen diversos conceptos sobre AI (Tessmer, 1983, citado por Breivik, 1985; Breivik, 1989; Kuhlthau, 1987; ALA, 1989); sin embargo, sólo el de la Asociación Americana de Bibliotecas, ALA (por sus siglas en inglés, American Library Association), incluye puntualmente el uso de la información en su definición. Es posible pensar que si Zurkowski ya lo había considerado en su definición, sólo se retomaría esta idea, se le agregarían características y se puliría la esencia (qué es); 
desafortunadamente, la tendencia se dio hacia acceder y evaluar efectivamente la información en genérico, sin acotar a qué se refiere concretamente este término. Se infiere que la AI se refería sólo a las herramientas secundarias, y a las habilidades para buscar, recuperar y evaluar la información recuperada en estas herramientas, sin llegar al uso de los contenidos de recursos primarios.

Otra veta de entendimiento fue la de Carol Kuhlthau, quien siempre ha realizado sus investigaciones dentro de instituciones de educación, básicamente de media superior; ella no genera una definición puntual de AI de forma operativa, la caracteriza y la vincula con habilidades y procesos mentales circunscritos al ámbito pedagógico, y declara que "la AI le permite a una persona a usar información para tomar decisiones y resolver problemas" (Kuhlthau, 1987, p. 2). Afirma que, además de localizar información, los estudiantes deben aprender a interpretarla, y a cómo usarla después de localizarla: "Pensar acerca de la información, buscar más información basada en pensamientos expandidos, y prepararla para presentársela a otros" (Ídem).

Esto muestra que, en su concepción mental y sobre el desarrollo de ideas, lleva la interpretación de los textos al plano del pensamiento crítico, y plantea que la interpretación (uso) de la información requiere procesos mentales como: observar, comparar, contrastar, predecir, agrupar y establecer metas. Al igual que Zurkowski, diferencia los recursos de información (primarios) de las herramientas (recursos secundarios) para localizar y recuperar información.

Al final de esa década (1989), la ALA emite "la definición" de persona alfabetizada, entre comillas, porque ésta ha sido la más retomada por los estudiosos del tema, una persona alfabetizada es aquella que:

Es capaz de reconocer cuándo necesita información y tiene la habilidad para localizarla, evaluarla y usarla efectivamente [...] Ha aprendido a aprender. Sabe cómo aprender porque sabe cómo está organizado el conocimiento, cómo encontrar la información, y cómo usarla de manera que otros puedan aprender de ella. Está preparada para 
el aprendizaje para la vida, porque puede encontrar la información necesaria para hacer cualquier tarea o tomar una decisión. (American Library Association, disponible en: Presidential Committee on Information Literacy. Final Report, Chicago: American Library Association, 1989, en: www.ala.org/ala/acrl/acrlpubs/whitepapers/presidential. htm, consulta: 12 de marzo de 2012).

Aparecen aquí un montón de ideas que no fueron cabalmente explicadas en ese momento por la Asociación, y luego simplemente la definición se ha retomado textualmente, tratando de acomodarla a diversos contextos, sin lograr hacerla operativa. Se han ido más a la inmediatez de tratar de aplicarla que a entender su esencia, lo que ha derivado en propuestas y programas que no han dado los resultados esperados y que eventualmente quedan olvidadas, mientras que sigue existiendo un gran debate sobre el concepto y la forma de llevar a cabo la AI (Badke, 2010).

Hagamos un análisis puntual de esta definición en relación con las connotaciones que tiene en cuanto al uso. Las habilidades o capacidades están ordenadas como etapas inclusivas: localizar, evaluar y usar, pero si esto es así, ¿después de usarse no se hace una evaluación? Tendremos que interpretar el significado de evaluación e información de acuerdo con el lugar en el que aparece.

En este estadio, la evaluación se refiere a medir la efectividad de la búsqueda y localización de la información registrada en herramientas secundarias, ¿pero qué tanto los resultados obtenidos se acercan o casan con la necesidad de información previamente establecida por un sujeto? Pongamos como ejemplo que se hace una búsqueda en la base de datos ERIC sobre técnicas didácticas para promover aprendizajes en adolescentes, con una cobertura temporal desde 2000 hasta la fecha, y que está en inglés; tal estrategia de búsqueda arroja 20 registros que habrá que "evaluar"; es decir, precisar su autoría, el tipo de documento que es y leer el resumen para establecer la conveniencia o no de su recuperación física y uso futuro.

Desafortunadamente, sucede que para algunos autores la búsqueda, recuperación y evaluación de los registros contenidos en 
una herramienta secundaria ya es algo que se considera como uso de la información; lo cual es parcialmente cierto, se explotan recursos para obtener datos. Sin embargo, no se ha completado el ciclo de la información puesto que el texto primario no ha sido procesado; es decir, utilizado.

En la definición de la ALA, lo enunciado como aprender a aprender y aprendizaje para la vida lleva a procesos cognitivos superiores vinculados con el pensamiento crítico y la reflexión, que los psicólogos del aprendizaje y pedagogos llevan hasta la metacognición, asunto que será tratado más adelante. Se menciona esto porque resulta de gran importancia que quienes se dedicarán a crear programas y/o estrategias de AI deberán poseer conocimientos relacionados con el diseño de experiencias de aprendizaje que generen o desarrollen el pensamiento crítico y la reflexión desde la didáctica y no sólo desde la práctica bibliotecaria; además de saber hacer, un sujeto debe saber por qué, para qué, cómo y qué es lo que varía de su hacer.

En los años noventa, sobresalen los conceptos de Christina S. Doyle (1994) y Christine S. Bruce (1999). Doyle no determina la esencia de una persona alfabetizada informativamente hablando, más bien describe once características o habilidades específicas que ésta debe poseer:

1. Reconocer que la información completa y precisa es la base para tomar decisiones inteligentes.

2. Reconocer la necesidad que hay para informarse.

3. Formular preguntas basadas en la necesidad de información.

4. Identificar los recursos de potenciales de información.

5. Desarrollar estrategias de búsqueda exitosas.

6. Poder acceder a diversos recursos de información, incluyendo las tecnologías basadas en las computadoras.

7. Evaluar la información.

8. Organizar la información para hacer aplicaciones prácticas.

9. Integrar la información dentro del cuerpo de conocimientos existente. 
10. Usar esa información con pensamiento crítico y para solucionar problemas.

11. Implicar autosuficiencia (citados por Hernández Salazar, 2012, p. 20).

Resaltan aquí cuatro características/habilidades, la 3, y las que van de la 9 a la 11, todas ellas relacionadas con aspectos cognitivos: preguntarse; asimilar y acomodar nueva información al acervo de conocimientos existente; y por último, reflexionar sobre ella (pensamiento crítico/metacognición).

Por su parte Bruce, en 1997, define a la AI como un constructo que le permite a un sujeto crear una relación e interacción específicas con la información, en forma de aprendizaje autodirigido que evalúa y usa una gran variedad de recursos, acercándose a ellos críticamente, por lo que desarrolla un significado y un estilo personal con respecto a la información. Más adelante (1999) crea el modelo Las siete caras de la AI, que explica las diferentes formas de experimentar la AI mediante 3 elementos o nodos clave: búsqueda de información (scanning); información tecnológica; y uso de la información, representados como círculos concéntricos, en los cuales varía el núcleo. Esta variación se da porque en cada cara o etapa los individuos tienden a acercarse a un elemento o nodo clave de acuerdo con la situación en la que se encuentren.

En las cuatro primeras representaciones o caras, el elemento uso de la información aparece en la última posición concéntrica, dándole prioridad en los nodos a la información como tecnología, fuentes, control y proceso; en las tres últimas el uso es lo importarte, hecho que se aprecia en los propios enunciados: "La quinta cara: la alfabetización informativa se experimenta como la construcción de una base de conocimiento personal en una nueva área de interés." (Bruce, 1999, p. 40).

Todo esto implica el desarrollo de una postura del individuo con respecto al nuevo conocimiento, pues toda vez que lo ha analizado y pensado críticamente, lo puede dirigir hacia un propósito específico. La sexta cara completa este proceso; en ésta, el sujeto conjunta conocimiento y experiencia para generar un 
estado intuitivo o de mirada creativa que lo lleva a recrear o crear nuevas formas de conocimiento, situación que se expresa de la siguiente manera: "la AI es experimentada como trabajar con el conocimiento y perspectivas personales adoptadas de tal manera que las introspecciones están incluidas" (Bruce, 1999, p. 4).

En la séptima y última fase del modelo, la AI se da cuando la información se usa sabiamente para el beneficio de otros; esto involucra la aprehensión absoluta de la información, de tal forma que se evidencie un producto que se compartirá con otros sujetos, hablamos de valores personales y éticos y de experiencias colaborativas. Lo anteriormente expresado muestra que en la década de los noventa, al igual que en la de los ochenta, está explícitamente expresada la importancia del pensamiento crítico en el proceso de AI, aunque sigue sin precisarse exactamente qué es y cómo se logra.

En Grassian y Kaplowitz, desaparece la tipificación de recursos de información (primarios) y herramientas (secundarias), y se menciona el término genérico de información, con lo que se pierde la idea no declarada de que se requieren aprendizajes diferentes para cada tipo de recurso.

A pesar de los logros en la conceptualización de la AI durante más de veinte años, en la primera década del siglo XXI se regresa al cuestionamiento sobre su concepto, si no se tiene clara su esencia no se podrá lograr una ciudadanía alfabetizada. Grassian y Kaplowitz (2001) hacen un recuento de la teoría y la práctica sobre la AI, en donde afirman que existen preguntas sin respuestas tales como:

- ¿Cómo reconocemos que alguien está alfabetizado informativamente?

- ¿Cómo sabemos que alguien ha aprendido a aprender?

- Más aún ¿cómo enseñamos "a aprender a aprender"?

- ¿Son atributos medibles reconocer una necesidad de información, cubrirla y evaluar críticamente la información?

- ¿Qué tipo de competencias necesita una persona para decir que está alfabetizada ahora y también en el futuro? 
Si se percibe a la AI como un cambio fenomenológico en la variación del mundo de un sujeto:

- ¿Cómo se caracterizan esos cambios?

- ¿Cómo se miden esos cambios?

- ¿La AI es un comportamiento observable o un conjunto de habilidades medibles?

- ¿La AI es de carácter cognitivo e interno y, por lo tanto, más difícil de cuantificar?

Con respecto a la noción de pensamiento crítico, estos autores cuestionan si los especialistas de la información:

- ¿Enfatizamos el pensamiento crítico y la evaluación de la información ante la gran diversidad de recursos, sobre todo los que se obtienen a través de la World Wide Web?

- ¿Promovemos el pensamiento crítico en nuestras sesiones?

- Al explicar diferentes tipos de recursos de información, ¿discutimos sobre la situación más propicia para su uso?

La respuesta a estas interrogantes brindará el marco conceptual de referencia básico para explicar la AI y, eventualmente, diseñar y/o elegir las estrategias, programas o propuestas más adecuadas al contexto problemático.

Hannelore Rader (1991) afirma que la AI está en sus comienzos y que se necesita más trabajo para entender la complejidad del fenómeno, los efectos a largo plazo y la importancia de preparar personal que haga un uso efectivo de la información.

En esa década, aparecen las principales normas de AI, generadas por asociaciones de profesionales (The Association of College and Research Libraries; American Association of School Librarians; The Society of College, National and University Libraries); en todas ellas existe una que se refiere al uso efectivo de la información. Se empiezan a hacer estudios de usuarios sobre los resultados de los programas de AI aplicados principalmente en instituciones de educación superior. Somi y Jager (2005) 
realizan una investigación para identificar la experiencia de los alumnos en el uso de la biblioteca y demás recursos, en el entendido de que han recibido cierta alfabetización. Cabe resaltar que si bien en su marco teórico incluyen aspectos relacionados con el uso como "el último y más valorado paso", e incluir alusiones a pensar críticamente, resolver problemas, ser aprendices independientes para toda la vida y haber aprendido a aprender, no son consideradas en sus preguntas de investigación, se concretan a preguntarles a los estudiantes si saben:

- la importancia de la orientación;

- cómo localizar información en la biblioteca;

- que el entrenamiento sobre el catálogo en línea y de otras bases de datos ayudan a los estudiantes a buscar en forma independiente;

- cómo evaluar críticamente la información;

- cómo citar la información recuperada (Somi y Jager, 2005, p. 260).

En ese artículo, es notoria la confusión que tienen sobre la noción de pensamiento crítico, adosan este último término a la etapa de evaluación de la información. También se percibe que les interesan sólo las herramientas secundarias, y el uso de la información lo circunscriben a la mera explotación del catálogo de su biblioteca y de algunas otras bases de datos. Esto reafirma la necesidad de aclarar en forma amplia el sentido del uso de la información.

Los hallazgos de este estudio muestran que, a pesar que en la universidad estudiada existen experiencias de "alfabetización informativa”, éstas no están logrando los objetivos planteados, ya que los estudiantes no aprenden gran cosa en los resúmenes de orientación e instrucción sobre el catálogo y las bases de datos.

Para cerrar esta década, resalta el artículo de William Badke (2010) cuyo título es “¿Por qué la alfabetización informativa es invisible?" La concreción de una respuesta lo llevó a analizar varios estudios realizados en universidades y colegios, de los que se desprendieron varias causas: 
- No existe claridad en su concepto e importancia.

- La Ai se realiza en una sesión de una hora o menos y está conformada por composiciones y escritos básicos.

- Esta situación hace que los docentes la perciban como poco importante.

- La figura de acreditación en el plan curricular es muy pobre (uno o dos créditos).

- Hay falta de entendimiento de la naturaleza de la AI: entender la información y cómo funciona.

- Tendría que percibirse como un asunto remedial y no de fondo. Se debe pensar en la información y su uso.

- La AI no es reconocida por los académicos que estudian aspectos pedagógicos. En 32 revistas que tratan temas sobre educación superior, más de la mitad no incluyen ninguna referencia sobre esta frase.

- No se vincula la AI con el proceso de investigación. De hecho los profesores no saben cómo formar para investigar, puesto que ellos han aprendido con base en el ensayo y el error.

- Más grave aún es que los profesores no consideran necesaria la existencia de asignaturas o contenidos destinados a enseñar a investigar; asocian la conclusión del nivel superior con un estadio de alfabetización informativa: todos los egresados están alfabetizados.

- Los profesores no perciben a los bibliotecarios como colegas debido a que, en ocasiones, sólo tienen grados terminales, tienen limitada experiencia docente y no publican nada.

- Se tiene la creencia de que la AI sólo se relaciona con la explotación de los recursos tecnológicos.

A manera de gran conclusión, Badke responde a su pregunta diciendo que la alfabetización informativa es invisible porque muy poca gente reconoce que hay ahí un problema por atender (Badke, 2010, p. 139).

Si bien la mayoría de los estudios que se han hecho sobre los resultados de programas de AI corresponden a instituciones 
de educación superior, es posible inferir que las de educación básica, media y media superior, de existir, estén en las mismas circunstancias, puesto que los estudiantes llegan con notorias deficiencias al nivel superior.

Como apoyo a las investigaciones sobre la evaluación de la AI, en 2007 el Centro para la Evaluación y Estudios de Investigación elaboró el instrumento de medida denominado El examen de $\mathrm{Al}$ fabetización Informativa (ILT, por sus siglas en inglés: The Information Literacy Test). El ILT es una prueba de 60 reactivos de opción múltiple; no obstante que el Manual declara estar basado en las normas de la ACRL (Association of College and Research Libraries), en realidad no contempla la cuarta norma, referida a asegurar la habilidad de los estudiantes para usar la información con el fin de cubrir un propósito específico.

En este análisis, para identificar el significado del uso de la información dentro de la literatura sobre AI, se rescatan dos asuntos principales: el uso de la información no está claramente definido como frase ni tampoco los términos uso e información; y para definir a la AI se incluyen las ideas de pensamiento crítico y reflexivo, y la evaluación crítica de la información, sin precisar su significado.

\section{Pensamiento crítico}

Como se pudo observar en el apartado anterior, en algunas definiciones de AI aparece la idea relacionada con el pensamiento crítico, la cual está estrechamente vinculada con el uso de la información. Pero también se estableció que éste no ha sido delimitado conceptualmente, por lo que cabe profundizar sobre el tema.

El pensamiento crítico es un fenómeno que ha sido estudiado por varias disciplinas, y dentro de una misma desde varias perspectivas, lo que lo convierte en multi e interdisciplinario. Básicamente interesan aquí las nociones de tres áreas: la filosofía, la psicología y la pedagogía. La filosofía lo estudia como una forma de razonamiento informal, práctico o cotidiano, y hace surgir aquí el termino razonamiento, y la duda ¿el pensamiento y el 
razonamiento son sinónimos? La respuesta es no, el pensamiento es una construcción mental, es lo que contiene un acto u operación intelectual "realizada por un sujeto, es el resultado de actos mentales del pensar, este constructo puede ser una imagen, un concepto o un procedimiento, debe poder comunicarse al sujeto que piensa y a otros sujetos." Es lo que se aprende en el acto de pensar, son designata de ciertos términos (Ferrater Mora, 2004, p. 2734).

Por otra parte, el razonamiento es un proceso formal de operaciones mentales deductivas o inductivas, y también puede entenderse como un conjunto de proposiciones vinculadas que, mediante la generación de premisas, llegan a conclusiones. El razonamiento está vinculado con el pensamiento; es un tipo de pensamiento que se manifiesta a través de afirmaciones y no a través de imágenes de índole perceptiva, intuiciones vagas o asociaciones de carácter emotivo (Gadino, c2005, p. 13) y se refiere a procesos de argumentación. El pensamiento está siempre en la mente y el razonamiento no; se puede decir que razonar es un orden superior de pensamiento: el pensamiento denominado pensamiento crítico.

Al ser la mente el objeto de estudio de los psicólogos, éstos han establecido y expresado las diversas capacidades y habilidades del pensamiento crítico: razonar, comprobar hipótesis, resolver problemas y tomar decisiones. Los psicólogos estudian la capacidad de la mente para responder a situaciones incompletas o problemáticas; de hecho, una situación incompleta ya es problemática o conflictiva.

Los pedagogos han retomado las experiencias de los psicólogos como base para diseñar y mejorar las experiencias de enseñanza y aprendizaje. Debido a que la AI se percibe como un proceso enmarcado en la educación, profundizaremos sobre la perspectiva pedagógica del pensamiento crítico, en donde éste es entendido como: "Una construcción mental razonable y reflexiva que se dirige a cierto aspecto, pregunta o problema y que permite decidir qué creer y qué hacer para resolverlos. Se basa en 
un cuestionamiento permanente y profundo sobre el fenómeno o problema." (Hernández Salazar, 2012, p. 28)

Lo crítico se refiere a que el "sujeto comprenda, reflexione y soluciones problemas de manera eficiente", debe juzgar, decidir y resolver de manera óptima (Saiz, c2002. p.16). El pensamiento crítico nos permite actuar de la siguiente manera ante una situación problemática que queremos resolver:

[...] primero nos esforzamos por definirla, analizarla y comprenderla; segundo, buscaremos formas de modificar esa situación (estrategia de solución); después, elegiremos la modificación que consideremos mejor; a continuación, la aplicamos y, finalmente, valoramos los resultados obtenidos (Ibíd., p. 17).

Si revisamos detenidamente estas etapas y las comparamos con las habilidades declaradas en las definiciones de la AI, nos daremos cuenta que es posible relacionarlas:

definir una necesidad de información = definir y comprender una situación

buscar, localizar información = buscar formas de modificarla evaluarla $=$ aplicar la mejor solución

En las etapas del pensamiento crítico, aparece la idea de analizar la situación antes de buscar formas de modificarla, lo cual se podría empatar con evaluar la información. La fase nueva es la valoración de los resultados después que se ha aplicado una solución. En la AI sólo aparece la evaluación después de que se ha recuperado la información en herramientas secundarias, pero no aparece como valoración, toda vez que se ha obtenido físicamente el recurso primario, se ha leído, analizado y sintetizado (asimilación y acomodo de la nueva información); es decir, la construcción de nuevo conocimiento. Valorar implica haber usado; sólo después de utilizar algún recurso podemos decidir sobre la mejor solución, resolver la situación problemática, y emitir un juicio de valor sobre la solución y la información que apoyó para generar tal solución. 
El pensamiento crítico se percibe en dos niveles cognitivos: la explicación de lo que se piensa, y la explicación del proceso que se realizó para llegar a ese pensamiento. En ambos estadios se requieren los siguientes procesos mentales: observar, interpretar, analizar, inferir, evaluar y explicar. En el segundo, se deben, además, aplicar razonamientos a estos procesos para mejorarlos o para sostener opiniones (argumentos), lo que lleva a la autorregulación cognitiva o también llamada metacognición.

Si bien algunos estudiosos de la AI hablan del pensamiento crítico, aunque no establecen su concepto, se infiere que se refieren a su primer nivel, explicar lo que se piensa, pero el segundo estadio, argumentar las decisiones que se tomen y explicar el proceso que se realizó para llegar a ese pensamiento, es decir, la metacognición, no ha sido abordado, por lo que cabe ampliar su sentido.

La metacognición es un proceso mental superior asociado con el aprendizaje, el cual permite identificar qué sabe un sujeto y cómo lo sabe, los procesos y operaciones cognitivos que realiza éste cuando aprende, recuerda o soluciona problemas, es el "conocimiento sobre el conocimiento" (Díaz Barriga Arceo y Hernández Rojas, c 2002, p. 235).

Este proceso puede concebirse desde dos planos, como conocimiento acerca de la cognición y como regulación de esa cognición. El primero, estudia la conciencia y comprensión de un sujeto sobre su saber, y el segundo las actividades relacionadas con la regulación y el control de la tarea cognitiva de aprendizaje o de la solución de problemas, concretamente cada plano implica los siguientes procesos cognitivos:

1. Conocimiento acerca de la cognición:

- ¿Qué?

- ¿Cómo?

- ¿Cuándo?

- ¿Dónde?

- Variables o categorías de conocimientos, de tres tipos:

- Persona: los saberes que posee; sus capacidades y limitaciones como aprendiz; los conocimientos que poseen 
otras personas, y los aspectos comunes en el proceso de aprendizaje. Generan conocimientos intraindividuales, interindividuales y universales.

- Tarea: características de la tarea y su relación con ella: a) naturaleza de la información; y b) demandas cognitivas que requerirán para realizar la tarea.

- Estrategia: distintas estrategias y técnicas que posee una persona para realizar distintos procesos cognitivos; su aplicación y eficacia.

2. Regulación de la cognición:

- Planificación: determinar la meta de aprendizaje; predecir los resultados, y seleccionar y programar estrategias.

- Aplicación: ejecutar la tarea.

- Monitoreo y supervisión: regular, seguir y comprobar el proceso y los resultados.

- Evaluación: estimar los resultados de las acciones estratégicas y los procesos en relación con ciertos criterios de efectividad y eficiencia, que se relacionan con el cumplimiento del plan y el logro de las metas establecidas (Díaz Barriga Arceo y Hernández Rojas, 2005, pp. 244-247).

Es posible determinar que ambas perspectivas son inclusivas y complementarias; el sujeto debe identificar lo que posee cognitivamente, y también, cómo logró incorporar lo nuevo para generar ese entramado cognitivo. El fin último de la metacognición es lograr que un sujeto autorregule su aprendizaje y responda a las preguntas: “¿Qué voy a hacer? ¿cómo lo voy a hacer? (planeación); ¿qué estoy haciendo? (aplicación); ¿cómo lo estoy haciendo? (monitoreo y supervisión); ¿qué tan bien o mal lo estoy haciendo? (revisión y evaluación)" (Díaz Barriga Arceo y Hernández Rojas, c2005, p. 247).

La autorregulación cognitiva da sentido a la idea tan repetida en varias proclamas internacionales sobre la AI: lograr que un sujeto aprenda a aprender. Entre los objetivos que persigue la educación a todos los niveles, incluida la AI, es que los sujetos 
que aprenden se conviertan en autónomos autorregulables; en otras palabras que aprendan a aprender, que aprendan de manera estratégica. Aprender a aprender es un proceso cognitivo directamente vinculado a la metacognición:

[...] implica la capacidad de reflexionar en la forma en que se aprende y actuar en consecuencia, autorregulando el propio proceso de aprendizaje mediante el uso de estrategias flexibles y apropiadas que se transfieren y adaptan a nuevas situaciones (Díaz Barriga Arceo y Hernández Rojas, c2005, p. 234).

Aparece aquí otro término que define a un sujeto alfabetizado informativamente y que va adyacente al pensamiento crítico, la reflexión o reflexionar, la frase es evaluar crítica y reflexivamente la información. ¿A qué se refiere la reflexión en un contexto de aprendizaje?

Partiremos de su acepción filosófica, ya que la mayoría de los términos que se integran a los marcos conceptuales disciplinares deben su sentido primigenio a la filosofía, la reflexión en este entorno significa:

El cambio de dirección de un acto mental, y específicamente de un acto intelectual, por medio del cual el acto invierte la dirección que lo lleva hacia el objeto y vuelve a sí mismo [...] es un acto de conciencia. A menudo se identifican "conciencia" y "reflexión" lo que lleva a considerar al sujeto humano como un ser fundamentalmente reflexivo (Ferrater Mora, c2001, p. 3033).

Este acto es inmediatamente posterior a la sensación sensorial; mediante la reflexión se generan las ideas generales que han llegado a la mente por uno o varios sentidos:

Una impresión golpea primeramente los sentidos y nos hace percibir calor o frío [...] placer o dolor [...] De esta impresión surge una copia tomada por la mente que permanece después de cesar la impresión. A esto llamamos idea. Cuando vuelve al alma, esta idea de placer o dolor 
produce las nuevas impresiones de deseo y aversión, esperanza y temor, que pueden ser llamadas propiamente impresiones de reflexión, porque se han derivado de ella (Ibíd., p. 3034).

Si ubicamos lo anterior dentro de la pedagogía se desprende que, dado que la reflexión es un acto mental innato en el sujeto, no es menester enseñarla o que alguien aprenda a hacerla, más bien debemos promover su aplicación en cada acto de aprendizaje. Dado su carácter de ir y venir sobre el objeto/impresión, esto habilitará al sujeto para relacionar los conocimientos sobre la cognición y su regulación y sacar inferencias o conclusiones sobre los actos de aprendizaje, lo que le permitirá enfrentar situaciones de aprendizaje futuras.

Atendiendo a este concepto, la reflexión es una actividad mental constante no privativa del contexto de aprendizaje; es más una característica connatural al sujeto que le permite fijar las sensaciones y retrotraerlas a alguna situación y variar o no dicha situación. Con lo cual permea todos los procesos mentales superiores relacionados con el aprendizaje, como son el pensamiento crítico, incluidas la metacognición y la autorregulación. En la Figura 1 se muestra el mapa conceptual que integra los elementos del pensamiento crítico.

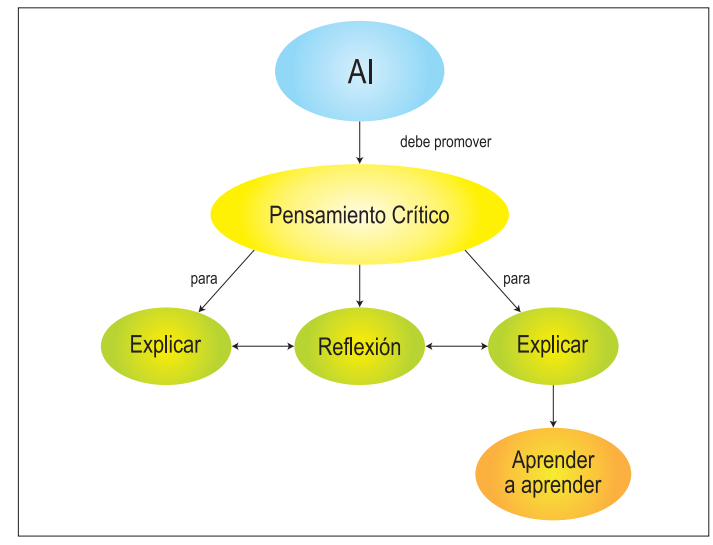

Figura 1.

Pensamiento crítico 
El perfil de un sujeto que ha aprendido a aprender incluye los elementos descritos en las tendencias de la metacognición convertidos en habilidades cognitivas:

- Controlan sus procesos de aprendizaje.

- Se dan cuenta de lo que hacen.

- Captan las exigencias de la tarea y responden consecuentemente.

- Planifican y examinan sus propias realizaciones, pudiendo identificar los aciertos y las dificultades.

- Emplean estrategias de estudio pertinentes para cada situación.

- Valoran los logros obtenidos y corrigen.

A todas luces, es necesario integrar este perfil a las habilidades que se pretende que adquieran los sujetos que serán alfabetizados informativamente; si logramos recrear en ellos estas habilidades, entonces podremos asegurar que han desarrollado la capacidad de pensar críticamente, reflexionan sobre ello y han aprendido a aprender.

El estudio puntual del pensamiento crítico genera más preguntas: ¿cómo lograr que los sujetos que aprenden conozcan sobre su cognición y la regulen?, ¿qué contenidos y experiencias de aprendizaje se les debe proveer para que alcancen procesos metacognitivos de autorregulación?

Todo esto, por otra parte, nos permite darnos cuenta de que en la práctica resulta difícil relacionar el pensamiento crítico con la AI; debemos entonces considerar que la clave para el diseño de estrategias, políticas o programas de AI está en conformar equipos de trabajo con pedagogos, coordinadores de aprendizaje de diversas disciplinas, tomadores de decisiones educativas a todos los niveles institucionales, y toda vez que se tengan listas las alternativas, conjuntar el esfuerzo, las voluntades de los involucrados y las decisiones a nivel nacional para implantarlas. 


\section{NOCIÓN DE USO DE LA INFORMACIÓN DESDE LOS ESTUDIOSOS DEL USO/UTILIZACIÓN DE INFORMACIÓN}

Existen al menos tres formas de nombrar a este fenómeno: uso del conocimiento; utilización de la información, o utilización del conocimiento; esto muestra que uso y utilización e información y conocimiento son tratados como sinónimos.

Cabe aclarar que si entendemos el conocimiento como una acción y producto de procesos mentales, se convierte éste en un ente abstracto y subjetivo imposible de asir o manipular, lo que hace insostenibles las frases uso o utilización del conocimiento, quedando así sólo dos maneras de mencionarlo como uso o utilización de la información.

El abordaje del fenómeno integral denominado usuarios de la información ha volteado recientemente hacia el uso de la información (finales de la década de los noventa del siglo pasado) y lo ha considerado como un subcampo fenoménico que debe formar parte del marco epistémico de la disciplina. Ross J. Todd fue el primero en tratar de darle sentido a la frase, retrotrayéndola de los modelos de otros autores que lo tocan explícita pero tangencialmente, y como parte de otros subcampos. Tal es el caso de Tom D. Wilson (1981, 1997, 1999, 2000), quien la integra como uno de los elementos de su modelo de Comportamiento Informativo, y Brenda Dervin $(1983,2003)$, en su teoría del sense-making (hacer o tomar sentido).

Wilson postuló en 1981 las bases para generar una teoría sobre el comportamiento de búsqueda de información, y notó que el uso de la información es una de las áreas más descuidadas; sin embargo, no abunda sobre ella en toda su obra. En 1996 publicó la primera versión de su modelo de comportamiento que está a la búsqueda de información, en el que incluye un elemento denominado procesamiento y uso de la información, como una parte necesaria para conformar el ciclo de su modelo (Wilson, 1999). 
En el año 2000 rehace su modelo y le da una connotación mayor y lo denomina Modelo de Comportamiento Informativo, en el cual aparece nuevamente la etapa de procesamiento y uso de la información, donde establece y define las cuatro áreas en las que se basa: comportamiento informativo; comportamiento en la búsqueda de información; comportamiento en la investigación de la información; y comportamiento en el uso de la información, la cual:

[...] consiste en los actos físicos y mentales involucrados en incorporar la información encontrada en la base de conocimiento existente en la persona. Puede incluir, actos físicos como marcar secciones de un texto para resaltar su importancia o significancia, tanto como actos mentales, por ejemplo, comparar la nueva información con el conocimiento existente (Wilson, 2000, p. 50).

A pesar de definir el uso como área básica de su modelo, cuando explica éste determina que el pensamiento y uso de la información es un estadio subjetivo, no directamente observable ya que está en la mente del individuo (Hernández Salazar, Ibáñez Marmolejo et al, 2007), problema que para ese tiempo ya estaba resolviendo Todd.

Por su parte Dervin, desde la década de los años setenta inició su investigación sobre la forma en que los sujetos le dan sentido a sus mundos, especialmente cómo construyen sus necesidades de información y eventualmente la usan (Dervin, 1983); no fue hasta la siguiente década que la nombró sense-making y la definió como el comportamiento tanto interno como externo que le "permite a un individuo construir y diseñar su movimiento a través del tiempo-espacio" (Dervin, 1983, p.3); esta investigación la hace a partir de la comunicación humana. Establece que la búsqueda y el uso de la información son actividades constructivas que le permiten al sujeto crear, construir o darle sentido a su vida, en un momento y un espacio específicos. El fin último de la investigación fue hacer posible un mejor diseño de sistemas y prácticas de comunicación, ya sea personales o mediadas y en cualquier medio. 
Los principios de esta tendencia subyacen en la contrastación de supuestos tradicionales sobre el uso de la información y los que ella propone:

Transmisión vs construcción. La información se concibe con base en la discontinuidad, se convierte en el significado que uno o más individuos le dan en un tiempo-espacio; la información no puede existir fuera de la actividad humana; es una acción interpretativa y no un objeto o producto de una acción. La información y el conocimiento rara vez son considerados como fines, se convierten en significados de los fines de los sujetos, y tienen posibilidad de cambios, flexibilidades y fluideces (lo discontinuo).

El uso de la información visto por el observador contra la visión del actor. El uso de la información y de los sistemas de información debe ser estudiado desde la perspectiva del actor, representado por el usuario que necesita, busca y usa la información. Interesa identificar lo que los usuarios realmente sienten, piensan, quieren y sueñan.

Uso de la información como una condición de estado contra una condición de proceso. El uso de los sistemas de información y de los recursos que el sistema provee se concibe como comportamiento, y se representa por los pasos que los usuarios emprenden para construir el sentido de sus mundos. Estos comportamientos pueden ser acciones internas, tales como: comparar, categorizar, enlazar, polarizar, estereotipar, etcétera; y externas, entre las que aparecen gritar, ignorar, agregar, desagregar, atender y escuchar, entre otras (Dervin, 2003).

En esta contrastación es posible percibir, entre otras ideas, la diferenciación que hace Dervin entre sistemas de información y recursos, lo que podríamos identificar como herramientas secundarias a los primeros, y como recursos primarios los segundos.

Para poder entender cabalmente el principio del uso de la información como un estado de proceso, Dervin se basa en la 
idea de brecha cognitiva; si bien ella no expresa el concepto de brecha cognitiva, el planteamiento y desarrollo de su propuesta permiten inferir que se trata de un hueco en el acervo de conocimientos de los sujetos que buscan información; el comportamiento de los usuarios se definirá de acuerdo a cómo se perciban ellos mismos al enfrentar una brecha específica y qué estrategias de comunicación utilizan para crear los puentes que cubren tal brecha; seguramente la brecha y la estrategia serán diferentes en diferentes momentos.

Cabe aclarar que si bien el fenómeno uso de la información es básico en toda la teoría del sense-making, Dervin no lo conceptualiza, sino que utiliza el proceso en forma pragmática, sin abundar sobre su sentido; estudia el uso como práctica de los seres humanos, y no como un ente abstracto que debe ser definido previo a su praxis.

Ross Todd es el primero en estudiar el uso de la información de manera holística, desde su concepto (esencia, características, propósito) hasta el proceso que muestra su aplicación. En su artículo "Back to our beginnings: information utilization, Bertram Brookes and the fundamental equation of information science" (1999) analiza desde una perspectiva cognitiva los diversos conceptos que existen sobre la utilización/uso de la información, y examina la ecuación de Brookes y la propone como base para investigar los aspectos cognitivos de la utilización de información.

De acuerdo con Todd, existen diferencias entre los términos uso (use) y utilización (utilization), afirmación que no aplica en el español, y en éste, el uso puede entenderse de varias maneras:

- Hacer servir una cosa.

- Una acción -la del verbo usar.

- Un efecto -o resultado de la acción de usar.

- Esa acción ejercida en forma continua y habitual, lo que lleva a una costumbre o manera de actuar característica de una persona, comunidad o entidad.

- Forma o modo de emplear o utilizar algo. 
En esta última acepción aparece la palabra utilizar, lo que significa valerse de alguien o algo para cubrir un fin determinado, o para sacar provecho o utilidad, significado semejante a la primera acepción, encontramos con esto la verdadera esencia del uso; se trata de una acción que se ejerce sobre algo, la cual se caracteriza porque es continua y habitual, y porque se precisa también del objetivo de esa acción para cubrir un fin determinado o sacar provecho de él. Lo anterior nos lleva a concluir que el uso implica utilizar algo, empleamos pues la frase uso de la información, y los términos uso y utilización son considerados como sinónimos.

Todd encontró varias aproximaciones conceptuales para la frase uso de la información, en las que los sujetos y la información van siempre unidos:

- Gente haciendo algo con la información. Como etapas previas a este "hacer", están el haber recogido la información en forma personal, o que se la hayan proporcionado y que la haya mirado sin leerla cabalmente.

- Lo que la información hace al o para el receptor y para resolver su problema o situación.

- Escuchar, mirar, leer, es decir, la recepción de la información y su entendimiento parcial o total por el receptor.

- Sujetos que se comprometen activa y propositivamente para hacer algo con la información recuperada para satisfacer sus necesidades de información percibidas.

En estas aproximaciones se aprecia que el uso es un estadio posterior a la búsqueda y recuperación de la información en herramientas secundarias (generalmente), e implica la lectura y entendimiento de lo recuperado; es decir, los recursos primarios por parte de un individuo. Es menester que se haga algo con la información "utilizada", ésta debe apoyar en la solución de un problema o en la toma de alguna decisión.

El estudio del uso de la información ha sido abordado desde dos perspectivas principales: a) instrumental; y b) conceptual. 
a) Instrumental. Empieza en los años setenta; se da dentro de un contexto organizacional o sistémico, y se conceptualiza como actuar, como un comportamiento actuante (estar haciendo), importan los estados finales (son la evidencia), los comportamientos externos, éstos representan los impactos tangibles de la información registrada. El fin es la transferencia directa de los hallazgos de la investigación (así en génerico como un acto social). Se retoma aquí la acepción de efecto de la acción, representada por los estados finales. Dado que éstos son concretos y tangibles, el uso desde esta perspectiva es susceptible de ser medido. Se percibe que una información ha sido utilizada "cuando es implementada como parte de un programa o dirige directamente una decisión específica o algún curso de acción" (Todd, 1999, p.853).

Esta perspectiva se puede vincular a la AI con el uso de herramientas secundarias, puesto que son medibles los resultados de acuerdo con la relevancia y pertinencia de los registros arrojados por el sistema de recuperación de información. Como estados finales pueden evaluarse las competencias que muestre el usuario en el manejo de catálogos, índices, resúmenes y bases de datos referenciales.

b) Conceptual. Tiene su origen en el paradigma orientado hacia el usuario, iniciado por los teóricos cognitivistas (Brookes, Belkin, Dervin) en los años ochenta, y se ubica en el contexto de las necesidades de información. El uso de la información se concibe en forma holística como "un proceso de cambio complejo e interactivo, cuya base es el proceso de pensamiento -un 'hacer' cognitivo- tanto como un 'actuar' los resultados comportamentales y los resultados finales." (Todd, 1999, p. 853).

También se entiende como uso de la información: "lo que está pasando en las mentes de la gente cuando hace algo con la información: actividad en la que uno procesa información, la interpreta y razona; sedimentación gradual de introspecciones, teorías, 
conceptos y formas de mirar el mundo" (Todd, 1999, p. 854). El uso conceptual de la información implica procesos mentales transformativos y formativos en los que la información se incorpora al acervo de conocimientos de una persona.

Esta perspectiva considera como conceptos centrales los cambios cognitivos y de comportamiento, el punto central es la dinámica compleja de las necesidades de información, el contexto, la búsqueda de información, la interacción con los recursos de información, y los resultados cognitivos y de comportamiento. Lo que hace que el uso conceptual de la información sea difícil de observar y medir.

El comportamiento se refiere a la totalidad de la actuación de un sujeto con respecto a la información: percepción y definición de una necesidad de información; búsqueda y recuperación de información; evaluación, selección de la información que resuelva la necesidad, uso de la información (cambios cognitivos y resultados).

Como resultado de este profundo análisis, Todd establece su concepto de uso de información, retoma la perspectiva conceptual y sigue el punto de vista cognitivo: "[...] es un proceso holístico que involucra procedimientos cognitivos y transformaciones que ocurren dentro de la mente de los individuos cuando trabajan con la información.” (Todd, 1999, p. 856)

Este concepto evidencia que en las propuestas de AI no se está considerando el verdadero sentido de uso de la información, habilidad que se circunscribe a la mera explotación de las herramientas secundarias, y refuerza los cuestionamientos sobre ¿cómo sabemos que un sujeto ha usado cierta información? ¿Cómo se logra que un sujeto aprenda a usar la información? ¿Cómo sabemos que ha aprendido a utilizarla? y ¿cómo medimos su uso?

Esta delimitación conceptual del uso de la información nos lleva a identificar dos elementos básicos: 1) es una acción que se ejerce; y 2) sobre un texto, necesariamente referido a un recurso primario.

Ya se aclaró que es un recurso primario en páginas anteriores; expliquemos ahora cómo se realiza esta acción del uso. Siguien- 
do el ejercicio dialógico de preguntas y respuestas, partamos de las siguientes: ¿cómo se produce la asimilación y acomodo de la nueva información en las estructuras cognitivas? y ¿de qué manera podemos percibir el cambio en las estructuras de conocimiento?

Dar respuesta a estas preguntas requiere realizar estudios de usuarios de corte cualitativo, observar de forma holística lo que hace un grupo determinado de individuos con la información y registrar cada etapa, de forma que haya un antes y un después de su estado cognitivo ante la lectura de un texto específico, interpretar esos resultados y emitir las conclusiones sobre el uso de ese grupo específico, para que eventualmente estos estudios puedan ser replicados.

En términos generales anotaremos aquí tres aspectos fundamentales relacionados con el uso de la información:
I) Fases
II) Estrategias cognitivas
III) Efectos

\section{I) Fases}

Se refiere a las etapas cognitivas que permiten la construcción de significados dentro de la mente de un sujeto, representadas por procesos de pensamiento; estas fases son: percepción, selección, creación de inferencias, ${ }^{1}$ y construcción de conocimiento.

Percepción. Primer contacto con la nueva información, el carácter de nueva está dado porque no embona dentro del acervo cognitivo de un sujeto.

Selección. Después de ese primer contacto con la información, se identifican los aspectos que van a permitir estabilizar el acervo cognitivo. Se forma una representación del objeto de conocimiento, y se empieza a entender el evento.

1 Se entiende por inferencia a la proposición (conclusión) derivada de premisas, ideas o proposiciones anteriormente construidas. 
Creación de inferencias. Se crean categorías cognitivas, se agrupan cosas o características que parecen diferentes y se convierten en equivalentes. Estas categorías se relacionan entre sí para generar proposiciones válidas; es decir, se razona (o crean razonamientos). Esto puede hacerse de dos maneras: mediante la combinación de varias partes de un texto para construir una imagen total y coherente del objeto cognitivo; o analizando elementos individuales del texto, para que el sujeto cree sus propias concepciones. Esta etapa permite tener una representación específica nueva del objeto, y un entendimiento cabal del mismo (Savolanein, 2009).

Construcción de conocimiento. Se retoma la nueva información, se transforma y se produce un nuevo entramado conceptual sobre tal o cual tema; se amplía o reduce una idea. Esta construcción le permite a un sujeto cambiar su concepción del mundo, crear un nuevo modelo a partir del que se tenía, y predecir "el tipo de resultados que se pueden lograr si uno actúa de acuerdo con el nuevo constructo [o conocimiento]" (Savolanein, 2009, p. 196).

\section{II) Estrategias cognitivas}

Son entendidas como las formas en que los individuos incorporan el nuevo objeto de conocimiento a su estructura cognitiva. Es el conjunto de pasos, operaciones o habilidades que un sujeto, ya sea consciente o inconscientemente, realiza al transformar la información nueva en conocimiento; son instrumentos flexibles para aprehender los nuevos conocimientos. Implican tres grandes procesos de pensamiento: transformación, integración de la información (asimilación y acomodo), y creación de nuevo conocimiento.

Para precisar el tipo de estrategias que se realizan durante el uso de la información, tomaremos como base la propuesta de Todd (1999), quien realizó un estudio cualitativo en adolescentes, en el cual el tema de interés fue la heroína. Los objetivos que se persiguieron fueron: 
(1) establecer los efectos a la exposición de información sobre heroína [...]

(2) establecer cómo los efectos percibidos están asociados con sus estructuras mentales [...].

(3) establecer los patrones, si existieran, en cada adolescente y entre las adolescentes en relación a los cambios en las estructuras de conocimiento y en los efectos percibidos (Todd, 100, p. 11).

El estudio se aplicó a cuatro mujeres de 17 años, estudiantes de preparatoria de una escuela en Australia, con niveles académicos altos, sobre todo en la lengua inglesa. Esta última característica se debió a dos causas principales: una, que debían entender los textos, y dos, que las evidencias de la interpretación de los textos con la consiguiente transformación cognitiva, fueron escritos a manera de ensayos y argumentaciones verbales. Después de cada exposición ${ }^{2}$ a los textos (lectura de los mismos), se les pedía que registraran los efectos percibidos y los cambios en sus estructuras mentales.

Esto muestra que existe una fuerte relación entre cognición y discurso; de hecho, éste es uno de los pilares del pensamiento crítico, el razonamiento para generar argumentos.

Si retomamos las habilidades incluidas en la mayoría de normas de AI, nos daremos cuenta de que siempre existe una habilidad sobre la comunicación de los resultados del uso de la información, como si el propio sujeto no se diera cuenta de que ha recreado su propio conocimiento; el pensamiento es lenguaje.

Las intervenciones se hicieron dentro de la escuela, como una actividad escolar incluida en la asignatura Desarrollo Personal, Salud y Educación Física; el tiempo fue controlado y se consideró la duración por un periodo de 50 minutos. Las estudiantes fueron expuestas tres veces a la información y después de cada exposición expresaron sus percepciones del evento, ya fuera en forma oral o escrita.

2 La exposición se definió como el acto de diseminar los mensajes contenidos en los textos, para que fueran leídos y que se reflexionara sobre ellos. 
Los datos se analizaron en tres etapas correspondientes a cada uno de los objetivos de la investigación:

Etapa 1. Establecer los efectos percibidos por las estudiantes luego de las exposiciones a la información.

Etapa 2. Identificar y conceptualizar los cambios de las estructuras de conocimiento de las estudiantes. El cambio se refiere a las alteraciones que se efectúan en la mente de los sujetos, como resultado de la exposición a la información. Se pretendió dar respuesta a las preguntas cómo, que se refiere a las estrategias que operaron sobre las estructuras de conocimiento, y qué, que corresponde a la naturaleza de las estructuras cognitivas que resultaron de las estrategias cognitivas (Todd, 1999).

Etapa 3. Establecer cómo los efectos percibidos de la exposición a la información se manifestaron en cambios en cada una de las estructuras.

Los resultados muestran que las estrategias cognitivas usadas fueron: agregar, insertar y borrar.

Agregar. Permite recolectar información, sumarla e integrar nuevas facetas o dimensiones a la idea preexistente, esto se logra de cuatro formas: expansión de las declaraciones generales; aumento de nuevas facetas o dimensiones; generación de enlaces entre un conocimiento y otro; y desencadenamiento de recuerdos.

Insertar. Se hacen ajustes complejos al acervo existente, se asimila y acomoda lo nuevo, es decir se deconstruye, construye, reconstruye y explica el nuevo conocimiento. Se sintetizan hechos para agruparlos en forma abstracta, y organizarlos en formas más coherentes (Savolanein, 2009).

Borrar. La nueva información puede hacer que ciertos elementos cognitivos ya no tengan cabida, de tal manera que se desechan.

Cabe aclarar que cada una de estas estrategias puede ser invocada de manera indistinta, no siguen un orden de acuerdo con el momento de la exposición a la información y la lectura de cada párrafo o apartado puede activar cualquiera de ellas. 


\section{III) Efectos}

Este aspecto se refiere al registro y establecimiento de los cambios cognitivos que es posible medir. Implica "comparar sistemáticamente las estructuras [cognitivas] a través de las diferentes exposiciones, y documentar todos los momentos específicos de los cambios en las estructuras" (Todd, 1999, p.139). Los cambios están directamente relacionados con las estrategias cognitivas. Es posible clasificar los cambios en cinco grandes grupos:

1. Obtener una imagen completa. Se amplían las afirmaciones generales y se convierten en más específicas y complejas. Se le agregan nuevas facetas o dimensiones a la idea existente; se hacen relaciones entre los conocimientos que se tienen claramente establecidos sobre un tema y los que están en el acervo de conocimientos sin identificar cabalmente; la nueva información desencadena recuerdos del tema en cuestión.

2. Obtener una imagen cambiada. Se determina si las ideas previas a la exposición eran correctas o incorrectas y se actúa en consecuencia; para lograrlo, se agregan, borran, reducen o insertan ideas al conocimiento que ya se tenía.

3. Obtener una imagen más clara. La nueva información aporta mayor significado y entendimiento en la cadena cognitiva de una persona.

4. Obtener una idea verificada. La idea preexistente es confirmada, defendida y reafirmada. En algunas ocasiones, pareciera que no hubo cambios; sin embargo, la sola posibilidad de asegurar una idea y reforzar su conocimiento es signo de variación.

5. Obtener una postura ante la imagen. Antes de leer información sobre un tema se tiene una idea general. Esta 
situación de conocimiento evoluciona hasta permitir la emisión de una opinión sobre tal conocimiento, con un punto de vista propio. Se está en posibilidad de crear un argumento que sostenga un juicio sobre el tópico leído, es decir, se ha generado un pensamiento crítico mediante la lectura, análisis, síntesis y reflexión, de lo plasmado en el texto (Todd, 1999).

Es después del proceso de uso de la información que, de acuerdo con las definiciones de los estudiosos de la AI y con las declaraciones vertidas en las normas, podríamos afirmar que un sujeto está alfabetizado informativamente.

Tener una idea clara del significado de uso de la información con base en los estudiosos cognitivistas y en los elementos que lo conforman (fases, estrategias cognitivas y efectos) permitirá diseñar experiencias o programas de Alfabetización Informativa efectivos, cuyos resultados sean consistentes y permitan su replicabilidad.

La univocidad conceptual permite consolidar una disciplina y crear comunidades epistémicas que compartan ideas; tal es el caso del fenómeno uso de la información, del cual se expresó aquí su significado: es un proceso bolístico que involucra procedimientos cognitivos y transformaciones que ocurren dentro de la mente de los individuos cuando trabajan con la información. Esta definición deberá ser retomada cuando se pretendan generar programas nacionales de Alfabetización Informativa.

\section{REFERENCIAS BIBLIOGRÁFICAS}

American Library Association, Presidential Committee on Information Literacy: Final Report, The importance of information literacy to individuals, business, and citizenship opportunities to develop information literacy, disponible en http://www.ala.org/ala/acrl/ acrlpubs/whitepapers/presidential.htm (fecha de consulta: 12 de agosto de 2012). 
The Association of College and Research Libraries (2000), Information Literacy Competency Standards for Higher Education, Chicago: American Library Association.

Badke, W. (2010), "Why Information Literacy is Invisible", en Communications in Information Literacy, 4 (2): 129-141.

Belkin, N. J. (1990), "The cognitive viewpoint in information science", en Journal of Information Science, 16 : 11-15.

Breivik, P. S. (1985), Information literacy: revolution in the library, New York: American Council on Education.

Brookes, B.C. (1980), "The foundations of information science, Part I: philosophical aspects: classes of things and the challenge of human individuality", en Journal of Information Science, 2: 125-133.

Bruce, C. S. (2002), Information Literacy as a Catalyst for Educational Change A Background Paper, Australia: Queensland University of Technology.

- —, (1997), The seven faces of information literacy, Adelaide, Australia: Auslib.

— - _, (1999), "Workplace experiences of information literacy", en International Journal of Information Management, 19: 33-47.

Council of Australian University Librarians, Information Literacy Standards, disponible en: http://www.caul.edu.au/caul-doc/InfoLitStandards2001.doc (fecha de consulta: 10 de agosto de 2012).

Dervin, B. (1983), "An overview of sense-making research: concepts, methods, and results to date", en International Communication Association annual meeting, Dallas, May. 
_ _ _, (2003), Sense-making methodology reader: selected writings of Brenda Dervin, Cresskill, New Jersey: Hampton Press.

Díaz Barriga Arceo, F.; Hernández Rojas, G. (2005), Estrategias docentes para un aprendizaje significativo: una interpretación constructivista, México: McGraw Hill.

Doyle, C. S. (1994), Information literacy in an information society: a concept for the information age, Syracuse, N.Y.: ERIC Clearinghouse on Information \& Technology, Syracuse University.

Ferrater Mora, J. (2001), Diccionario de Filosofía, Barcelona: Editorial Ariel, s. A.

Gadino, A. (c2005), La construcción del pensamiento reflexivo: procedimientos para aprender a razonar en el Nivel Inicial y 1er. ciclo de la E.G.B., Argentina: Homo Sapiens Ediciones.

Grassian, E. S.; Kaplowitz, J. R. (2001), Information Literacy Instruction: theory and practice, New York: Neal-Schuman Publishers, Inc.

Hernández Salazar, P. (2012), Tendencias de la Alfabetización Informativa en Iberoamérica, México: UNAM, Centro Universitario de Investigaciones Bibliotecológicas.

Hernández Salazar, P.; Ibáñez Marmolejo, M.; Valdez Ángeles, G. Y.; Vilches Malagón, C. (2007), "Análisis de modelos de comportamiento en la búsqueda de información”, en Ciência da Informação, 36 (1): 136-146.

The Information Literacy Test (ILT): Test Manual (2009), disponible en: http://www.madisonassessment.com/uploads/ILT\%20Test\%20 Manual\%202010.pdf (fecha de consulta: 23 de julio de 2012). 
Kari, J. (2007), "Conceptualizing the personal outcomes of information" en Information Research, 12 (2), disponible en: http://informationr.net/ir/12-2/paper292.html (fecha de consulta: 5 de julio de 2012).

Kuhlthau, C. C. (1987), Information Skills for an Information Society: a review of research, Syracuse, New York: Syracuse University.

Rader, H. (1991), "Information literacy: a revolution in the library", en $R Q, 25-29$, Fall.

Saiz, C. (c2002), Pensamiento crítico: conceptos básicos y actividades prácticas, España: Ediciones Pirámide.

Savolanein, R. (2009), "Information use and information processing: comparison of conceptualizations", en Journal of Documentation, 65 (2): 187-207.

Somi, N. G.; Jager, K. (2005), "The role of academic libraries in the enhancement of information literacy: a study of Fort Hare Library", en SA Jnl E Info Sci, 71 (3): 259-267.

Spink, A.; Cole, C. (2006), "Human Information Behavior: Integrating Diverse Approaches and Information Use", en Journal of the American Society for Information Science and Technology, 57 (1): 25-35.

Todd, R. J. (1999), "Back to our beginnings: information utilization, Bertram Brookes and the fundamental equation of information science", en Information Processing and Management, 35: 851870.

— — - (1999), "Utilization of Heroin Information by Adolescent Girls in Australia: A Cognitive Analysis", en Journal of the American Society for Information Science, 50 (1): 10-23. 
Wilson, T.D. (2000), "Human information behavior", en Information Science, 3 (2): 49-55.

- — - (1981), On user studies and information needs, disponible en: http://informationr.net/publ/papers/1981infoneeds.html (fecha de consulta: 20 de mayo de 2012).

Wilson, T.D; Walsh, C. (1997), "Information behavior: an interdisciplinary perspective", en Information Processing \& Management, 33 (4): 551-572.

— — _, (1999), Models in information behaviour research, disponible en: http://informationr.net/tdw/publ/papers/1999JDoc.html (fecha de consulta: 7 de septiembre de 2012).

Zurkowski, P. (1974), The information service environment relationships and priorities, National Commission on Libraries and Information Science, Related Paper Number Five. 


\title{
La educación a distancia en bibliotecología en México y América Latina: elementos para una agenda de investigación
}

\author{
ROBERTO GARDUÑO VERA \\ Universidad Nacional Autónoma de México
}

\section{INTRODUCCIÓN}

\begin{abstract}
0 e asume que una agenda de investigación orientada a la educación a distancia en bibliotecología es una tarea de carácter participativo que conduce a la colaboración de profesionistas, investigadores y docentes de la disciplina, pedagogos, lingüistas, y profesionistas en Tecnologías de Información y Comunicación (TIC), entre otros. La participación de todos ellos es importarte debido a que la educación a distancia ${ }^{1}$ incorpora teorías, métodos, tecnologías, aplicaciones y servicios orientados a incidir en el aprendizaje independiente y en colaboración, con la mediación de materiales didácticos y de tecnologías educativas; por lo tanto, la educación a distancia es un objeto de investigación multifactorial que hace deseable la participación multidisciplinaria.

La penetración de esta modalidad en el mercado de la educación suscita la reflexión sobre sus posibles repercusiones en

1 Educación a distancia: modalidad educativa que promueve en el estudiante el aprendizaje independiente, con la mediación de materiales didácticos y de TIC; además, propicia la interacción cooperativa y colaborativa de los diferentes actores del proceso educativo, de manera síncrona y asíncrona, en UNAM, Coordinación de Universidad Abierta y Educación a Distancia (CUAED), Consejo Asesor, UNAM, 2005 (documento de trabajo).
\end{abstract}


la sociedad y en la educación del presente siglo, debido a que ha propiciado el desarrollo de escenarios virtuales en los que el aprendizaje individual y en colaboración determinan dinámicas orientadas al aprendizaje a distancia. Dichos aspectos representan desafíos para las disciplinas; sin embargo, acarrean beneficios para las sociedades contemporáneas. Enseñanza y tecnologías convergen para aglutinar procesos educativos, contenidos, canales de comunicación y actores del aprendizaje.

En este contexto, en la década de 1970, la educación superior a distancia en América Latina se observaba como la expresión de un quehacer innovador, reflejado en cambios didácticos, programas no convencionales, nuevas instituciones educativas y un conjunto de propuestas teóricas sobre la renovación de estructuras y métodos de aprendizaje. ${ }^{2}$ Pero, a partir de 1990, se advierte un incremento de propuestas educativas a distancia, atribuido a la consideración de que esta modalidad representa una alternativa para democratizar la educación, enfrentar la influencia de la globalización, los requerimientos de la sociedad de la información, de la sociedad del conocimiento, y la constante aparición de tecnologías en la prestación de servicios educativos. En el año 2012, tales fenómenos han puesto de manifiesto una mayor necesidad de incidir en la investigación permanente dirigida a estudiar las posibilidades que puede ofrecer la educación a distancia en las sociedades del siglo en que vivimos.

Al mismo tiempo la investigación a distancia en bibliotecología hace visible el requerimiento de abordar fenómenos de estudio innovadores; sin embargo, conviene en principio preguntar: ¿cuál es la situación de la investigación sobre la educación a distancia en bibliotecología en México y América Latina? Y para dar respuesta a ésta y otras interrogantes se consideraron prin-

2 Eulises Merlano Domínguez, "Estado del arte sobre investigación en educación de niños menores de siete años en el Departamento de Magdalena”, en Revista Electrónica EUREKA: Barranquilla, Colombia, Vol. 1 (1999), disponible en: http://www.uninorte.edu.co/divisiones/ humanidades/Eureka/Numero1/articulos5.htm (consulta: 11 de agosto de 2012). 
cipalmente los resultados emanados de un estado del arte sobre educación a distancia en bibliotecología en América Latina, ${ }^{3}$ y del estudio intitulado "Research areas in distance education: a delphhi study". ${ }^{4}$ Con base en estos estudios, entre otros documentos, se identificaron las tendencias temáticas y los posibles núcleos de interés, tanto científicos, como sociales sobre los cuales se podría orientar una agenda de investigación en educación a distancia en bibliotecología. Por lo anterior este trabajo se orienta a identificar núcleos temáticos de investigación relevantes, lo que induce a considerar aspectos teóricos y empíricos de la educación a distancia que ayuden a identificar fenómenos de estudio para una agenda de investigación sobre el tema mencionado.

\section{ELEMENTOS SIGNIFICATIVOS SOBRE LA EDUCACIÓN A DISTANCIA EN BIBLIOTECOLOGÍA EN LOS INICIOS DEL SIGLO XXI}

La incorporación de la educación a distancia en la disciplina bibliotecológica ha repercutido en la investigación y en la enseñanza en el área, debido a que los avances científicos y tecnológicos les plantean diversos retos a la disciplina, a los sujetos del acto educativo, a los sectores bibliotecarios y a las bibliotecas, en tanto que se advierten transformaciones en las formas de trabajo y en las maneras de interactuar y comunicarse entre los sujetos del acto educativo.

3 Roberto Garduño Vera y Brenda Cabral Vargas, "La investigación a distancia en bibliotecología en México y en América Latina”, en Filiberto Felipe Martínez Arellano y Juan José Calva (comp.), Tópicos de investigación en bibliotecología y sobre la información, edición conmemorativa de los XXV años del Centro Universitario de Investigaciones Bibliotecológicas, México, UnAM: Centro Universitario de Investigaciones Bibliotecológicas, 2007, v2.

4 Olaf Zawacki-Richter, "Research areas in distance education: a delphi study", en The international review of research in Open an Distance Learnnig, col 20(39) 2009, disponible en: http://www.irrodl.org/index.php//irrodl/rt/printerFriendly/674/1260 (consulta: 3 de septiembre de 2012). 
En un ambiente de escenarios virtuales, las funciones de los bibliotecarios y de las bibliotecas como centro de acopio y conservación y difusión de conocimiento, adquieren una nueva dimensión debido a que, por una parte, el bibliotecario enriquece su perfil, dado el requerimiento de incorporar el nuevo conocimiento y los avances tecnológicos y a que, por otra, las bibliotecas se enfrentan a una comunicación que integra los procesos de escribir, editar, publicar, desarrollar colecciones y organizarlas en bibliotecas digitales, repositorios, sistemas de metadatos y redes sociales académicas.

Tales aspectos, relacionados con la educación a distancia, hacen notar la urgencia de revisar las teorías bibliotecológicas, el concepto de la biblioteca, sus servicios y los del profesional que la atiende, pues, aunque estén realizando las mismas actividades sustantivas propias de la bibliotecología (seleccionar, representar, organizar, recuperar conocimiento registrado, y difundirlo), existen diferencias que derivan del uso de las tecnologías como mediadoras de los servicios de información, que le exigen al bibliotecario replantear la naturaleza de los servicios de información para lograr que el usuario a distancia pueda contar con elementos que le faciliten recuperar la información que requiere en su aprendizaje.

También es visible el interés de diversas instituciones educativas por incidir en las propuestas a distancia, las cuales han tenido un incremento substancial en los primeros años del siglo que vivimos. Se ha dicho con acierto que se advierte un mundo en donde las redes de teleproceso apoyan cualquier actividad humana y que las escuelas virtuales se orientan a ser el común denominador del sistema educativo en los años por venir.

Se ha hecho claro que las tecnologías han influido en el panorama actual de la educación a distancia de manera principal, en las formas de la comunicación, interacción, y en la manera de hacerle llegar a los usuarios los recursos educativos para el aprendizaje. Por tanto, la investigación y la enseñanza a distancia de la bibliotecología precisan estudiar las posibilidades de interacción orientadas a que el alumno cuente con facilidades para realizar su aprendizaje al combinar las ventajas que cada canal de comunica- 
ción pueda ofrecer. Al mismo tiempo, Internet se ha convertido en una herramienta informativa cuyo potencial de uso para la educación a distancia, en términos de recursos didácticos, es de gran valor para el aprendizaje y en diversas actividades de la sociedad mundial.

Este hecho es de primordial importancia para los tutores de la comunicación educativa a distancia, porque una de sus tareas relevantes es programar la mediación pedagógica entre el estudiante, el currículum y los contenidos educativos. Por tanto, es indispensable que tales recursos sean identificados, seleccionados, depurados y organizados de tal manera que sean relevantes y pertinentes para el aprendizaje que se está buscando.

Al mismo tiempo, diversas instituciones educativas cuyo modelo académico ha sido tradicionalmente presencial tienden a incidir cada vez más en propuestas educativas a distancia por las facilidades que ofrece la tecnología educativa, ante la oportunidad de generar alternativas educacionales en beneficio de amplios sectores sociales, y para evitar el riesgo de quedar reducidas a mercados educativos residuales.

Las ofertas basadas en la educación a distancia se incrementan en forma constante y proceden principalmente de dos sectores: instituciones educativas de nueva creación concebidas para impartir formación a distancia e "[...] instituciones tradicionales de formación presencial, pero que la combinan con procesos a distancia". ${ }^{5}$ Esta situación está presente con mayor énfasis en la educación de los primeros años de este siglo, debido a que las tecnologías recientes ofrecen diversas posibilidades de comunicación e interacción con los alumnos, controles académicos versátiles, y el diseño de materiales educativos basados en estructuras de hipertexto e hipermedia. ${ }^{6} \mathrm{Al}$ mismo tiempo, se acentúa el uso de la videoconferencia interactiva, el correo electrónico, la

5 Ibidem, p. 243.

6 Ramiro Lafuente López y Roberto Garduño Vera, "Enseñanza a Distancia de la Bibliotecología y Estudios de la Información”, en Investigación Bibliotecológica: archivonomía, bibliotecología e información, jul./dic., 1999, Vol. 13, No. 27, p. 16. 
biblioteca digital, los repositorios de objetos de aprendizaje, los sistemas de metadatos, los servicios de diseminación selectiva de la información basados en tecnologías de vanguardia, y la transferencia de documentos digitales de acceso abierto, como apoyo a la educación a distancia.

También el desarrollo de interfaces dinámicas ha propiciado un aumento exponencial de usuarios en las modalidades educativas a distancia; muchos de ellos interactúan y navegan en diversos cursos en escenarios virtuales y recuperan información electrónica. Sin duda, los documentos digitales almacenados en la Web constituyen un frente de investigación sustantivo para la informática, la psicología, la pedagogía, la bibliotecología, la documentación y, en general, para todas las disciplinas, ya que es un fenómeno que las afecta dadas las repercusiones que ya se observan en la educación a distancia actual.

\section{LA EDUCACIÓN A DISTANCIA EN MÉXICO Y AMÉRICA LATINA: FENÓMENOS DE ESTUDIO PARA UNA AGENDA DE INVESTIGACIÓN}

México es uno de los países que tiene un marcado interés en desarrollar investigación y propuestas educativas relacionadas con la educación a distancia en bibliotecología. Muestra de ello es la investigación que realiza el Instituto de Investigaciones Bibliotecológicas y de la Información de la UNAM, la existencia de la licenciatura y la maestría y el doctorado en Bibliotecología y Estudios de la Información de la UNAM, la licenciatura de la Escuela Nacional de Biblioteconomía y Archivonomía de la SEP, la licenciatura de la Universidad de Guadalajara Virtual, y la maestría del Instituto Tecnológico de Estudios Superiores de Monterrey.

En relación con otros países de América Latina y el Caribe que ofrecen propuestas educativas a distancia en bibliotecología se encuentran, entre otros, los siguientes: Puerto Rico, Costa Rica, 
Mar del Plata (Argentina), Cuba, Uruguay, Colombia, y Brasil, ${ }^{7}$ como se muestra en la Figura 1.

Figura 1.

Países de América Latina donde se ha escrito sobre Educación a Distancia

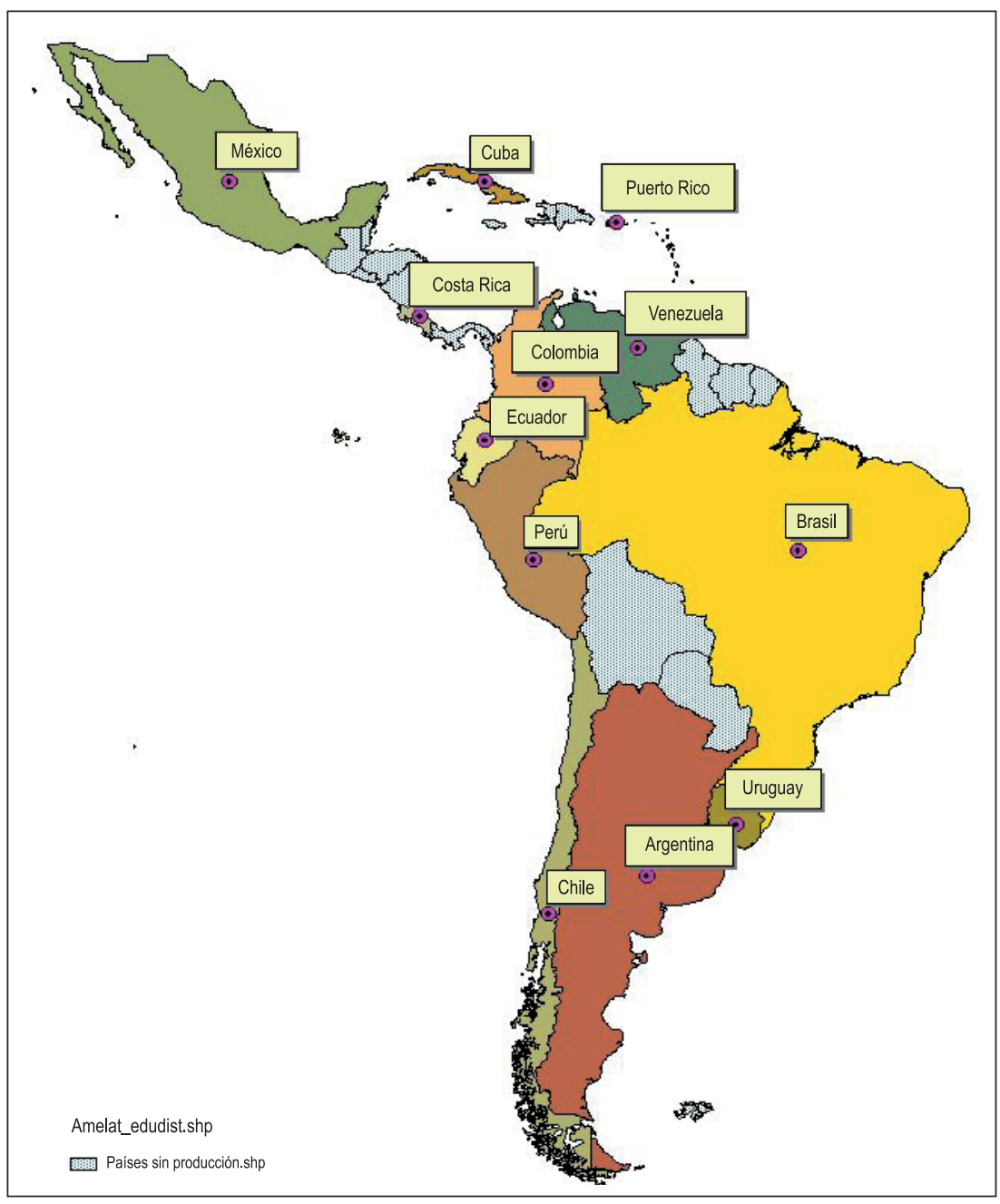

Fuente: Roberto Garduño Vera y Brenda Cabral Vargas, op cit.

7 Roberto Garduño Vera Roberto y Brenda Cabral Vargas, op. cit. 
No obstante lo anterior, se puede afirmar que la región latinoamericana debe incidir en el estudio de fenómenos emergentes a través de investigaciones individuales y colectivas donde se incorpore la colaboración interdisciplinaria y multidisciplinaria, lo cual conduce a la formación de grupos de investigación de instituciones de la región y, en su momento, considerar la cobertura internacional. Al mismo tiempo, la investigación bibliotecológica precisa considerar la innovación educativa a largo plazo para insertar a sus egresados en la competitividad que exige la internacionalización de la educación superior y la movilidad de profesionales, tomar en consideración el desarrollo cultural y la creciente cooperación en un mundo global. Sin duda, los efectos de los desarrollos científicos y tecnológicos de la investigación bibliotecológica inducen a su enriquecimiento y a su articulación con el conocimiento multidisciplinario, al mismo tiempo que redefinen su función en los paradigmas de investigación y educación emergentes.

Con base en lo expuesto en párrafos precedentes, a continuación se proponen los fenómenos que en la actualidad podrían ser los de mayor relevancia en la región latinoamericana para ser considerados en una agenda de investigación sobre educación a distancia. Tales objetos se estructuran en los siguientes:

\section{EJES DE INVESTIGACIÓN}

1. Acceso, equidad y ética

- Democracia y educación.

- Infraestructura tecnológica.

- Soporte documental.

2. Aprendizaje en la educción a distancia

- Estilos de aprendizaje.

- Convergencia de teorías y tecnologías. 
- E-aprendizaje

- Aprendizaje avanzado distribuido.

- Comunidades y redes de aprendizaje.

- Sociedad del aprendizaje.

- Virtualidad en educación.

- Resistencia y transformación cultural.

- Género y aprendizaje a distancia.

3. Sujetos de la educación a distancia

Tutores

- Perfiles docentes inducidos por la globalización, la sociedad de la información, la sociedad del conocimiento y las tecnologías.

Alumnos

- Trayectoria escolar.

- Deserción.

- Migración.

- Tribus urbanas.

- Nuevas formas de movilidad.

- Evaluación permanente del desempeño docente.

4. Contenido educativo

- Contenido educativo ex profeso.

- Objetos de aprendizaje como innovación educativa.

- Biblioteca digital y repositorios como fuentes documentales de valor agregado en la educación a distancia.

- Derechos de autor y uso de contenido educativo en Internet. 
Agendas de Investigación en Bibliotecología...

5. Currículum y formación a distancia

- Currículum, disciplina bibliotecológica y requerimientos sociales.

- Currículum flexible.

- Efectividad de las propuestas curriculares.

6. Evaluación en la educación a distancia

- Evaluación del currículum.

- Desempeño de la tutoría.

- Pertinencia de los contenidos educativos.

- Monitoreo del funcionamiento de tecnologías educativas.

7. Tecnologías de la Información y la Comunicación

- Escenarios virtuales de aprendizaje.

- Redes académicas.

- Tecnología móvil.

8. Historiografía de la educación a distancia

- Recuperar y comparar lo acontecido en cuento a sujetos del acto educativo, instituciones y los productos educativos.

- Investigar sobre la comprensión, interpretación y valoración de los hechos educativos a partir del análisis y las valoraciones para reconstruir la realidad investigativa.

- Explicar los cambios de rumbo educativo, conflictos, desempeño de tutores y financiamiento.

Los temas de investigación mencionados podrían perfilar una agenda de investigación en educación a distancia en bibliotecología. Se insiste que el abordaje de los fenómenos de investigación mencionados requiere de la participación multidisciplinaria porque la bibliotecológica precisa desarrollar tanto en investigacio- 
nes individuales como en colectivas a través de la formación de grupos de investigación de diversas disciplinas.

Al mismo tiempo debe considerar la innovación para insertar a sus egresados en la competitividad que exige la internacionalización de la educación superior y la movilidad de profesionales, tomando en consideración el desarrollo cultural y la cooperación en un mundo global, entre otros elementos. Lo anterior representa una posibilidad de enriquecer la investigación y la disciplina con el propósito de que se articule con el conocimiento multidisciplinario, y de que ambos redefinan su papel en el contexto de los objetos de investigación y los paradigmas emergentes de cara a la sociedad de la información y a la sociedad del conocimiento.

Algunos fenómenos de investigación que se observan con mayor urgencia se relacionan con los siguientes objetos: 1. La tutoría en la educación a distancia, 2. El currículum flexible, y 3. Los objetos de aprendizaje como innovación educativa.

Tutoría en la educación a distancia

Con respecto a la investigación sobre la tutoría en la educación a distancia, se puede decir que el abordaje de problemas relacionados con la formación docente ha tenido un importante incremento en los últimos años, a raíz del propósito de diversas instituciones educativas de elevar la calidad, la eficacia y la necesidad de hacer llegar servicios educativos a una mayor población. Así, la exigencia social sobre propuestas educativas, las facilidades tecnológicas para construir escenarios virtuales de aprendizaje y la orientación del currículum flexible demandan formas distintas y novedosas de comunicación y de interacción entre los sujetos del acto educativo.

Lo anterior lleva a replantear los modelos tradicionales para la formación docente, porque existe evidencia de que diversos programas de esta naturaleza continúan reproduciendo las prácticas escolares tradicionales, y que las políticas tienden a subordinar la formación docente a los requerimientos de las reformas educativas en las que la participación de los docentes se ha circuns- 
crito al papel de ejecutores de tales políticas. En consecuencia la formación, al parecer, continúa siendo una imposición desde las cúpulas, antes que un espacio para hacer propuestas educativas innovadoras. ${ }^{8}$ Cabe resaltar que en la educación a distancia el tutor es un elemento indispensable para lograr el adecuado desarrollo del proceso de aprendizaje. Por ello es conveniente que cuente con sólidos principios teóricos sobre la modalidad mencionada, las funciones específicas de la tutoría, y que adquiera o enriquezca sus habilidades relacionadas con el manejo de tecnologías educativas.

Ya que la educación es afectada por un entorno social, político, económico e histórico, hace falta que los docentes en bibliotecología de América Latina participen activamente en la formulación de propuestas críticas, reflexivas y analíticas para incidir en los requerimientos actuales de la bibliotecología, en tanto que se ha hecho evidente que en los ambientes de aprendizaje a distancia son necesarias acciones activas y contundentes relacionadas con la creación de estrategias que fortalezcan la formación de tutores que integren procesos didácticos dirigidos a los nuevos cuadros académicos, y que se actualicen en forma interdisciplinaria en nuevas didácticas y tecnologías educativas. La formación sustantiva del tutor exige tener una conciencia cultural y política de lo que significa ser docente en su sociedad. ${ }^{9}$

Dichos asuntos se han revalorado hoy debido al desarrollo y uso de tecnologías educativas en el aprendizaje en escenarios virtuales, a la generación de propuestas educativas no convencionales, a la necesidad de darles una formación permanente de los autores de contenido y de los tutores. Al mismo tiempo, cabe destacar el interés de instituciones educativas y de diversos gobiernos latinoamericanos que buscan ampliar la cobertura social de la educación en todos sus niveles. Tales implicaciones han abierto debates en

8 Martha Diana Bosco Hernández, "Dos conceptos paradigmáticos en la formación docente, la Areté y la Bildung: Una propuesta de reflexión para la educación virtual", en Virtual Educa 2005 (editado en CD-ROM) (consulta: 27 de junio de 2012).

9 Ibídem. 
diversos grupos relacionados con la educación a distancia respecto a las figuras que requiere la enseñanza de esta naturaleza, entre las que se destacan: la tutoría y el autor de contenido.

\section{Currículum flexible}

Considerar en una agenda de investigación este fenómeno es indispensable, en tanto que sintetiza la historia, la tendencia y la utopía de una triple relación que se debate entre el ser y el deber ser: la educación y la sociedad; la educación y la ciencia, y la educación y la pedagogía. En este sentido el currículo es un proceso complejo de institucionalización, organización y socialización del conocimiento en el que convergen las dimensiones social, cultural, política, pedagógica, científica y tecnológica, y que tiende a dibujar el horizonte de una sociedad respecto a la orientación de los cambios en la enseñanza a distancia. ${ }^{10}$

La estructura curricular flexible es aquella en la que la enseñanza tiende a la ciencia-acción como forma de consolidar a largo plazo una práctica reflexiva del saber y del saber hacer.

Persigue adecuar permanentemente los nuevos conocimientos a los procesos de información; promueve la capacidad de decisión en el alumno en el momento de elegir los créditos que debe cursar y determina el ritmo de los estudios; fomenta el trabajo colegiado de docentes e investigadores al dar una nueva función a la academia; propicia la comunicación horizontal y vertical de los contenidos; facilita la movilidad de los actores académicos; persigue un aprendizaje integral mediante el contacto con el mundo circundante; vincula a la Universidad con distintas instituciones de la sociedad; busca la formación de un hombre comprometido con sus circunstancias, reflexivo y polivalente [...]; estimula la interdisciplinariedad [...] al situar a la disciplina en el área del conocimiento y al actuar en la

10 René Pedroza Flores, "Propuesta de un modelo curricular flexible para mejorar la calidad de la formación profesional", en DEP: Cuadernos para la Educación Pública, 2004, p. 159. 
resolución de problemas reales; redimensiona el papel que juega el docente como sujeto social que convoca al alumno a establecer el diálogo [educativo] para explorar sus propias intencionalidades; y hace viable el sistema de créditos. ${ }^{11}$

Investigar en forma permanente sobre el currículum flexible es necesario porque los avances científicos y tecnológicos perfilan importantes avances en las disciplinas, entre los que se destacan:

la acotación de la distancia entre el momento de construcción del conocimiento y el momento de su incorporación a determinado programa académico; la comunicación entre disciplinas como parte inherente de la complejidad de los objetos y problemáticas del mundo circundante; la cantidad de información científica y tecnológica se incrementa constantemente, la emergencia de campos híbridos; la movilidad académica, la evidente participación interdisciplinaria y los nuevos requerimientos del campo laboral. ${ }^{12}$

En estos entornos se está dando la orientación de la investigación curricular, aspecto que la bibliotecología difícilmente puede ignorar.

Objetos de aprendizaje como innovación educativa

Las Tecnologías de Información y Comunicación (TIC) han enriquecido las formas en cuanto al desarrollo de contenido educativo a través de la convergencia de las telecomunicaciones y la informática. Asimismo, el empleo de modelos dirigidos al desarrollo de contenido educativo presupone acudir a la aplicación de principios teóricos del aprendizaje para procurar hacer llegar al estudiante un discurso académico que lo incite a la reflexión y a la crítica.

11 Ibidem, p. 160.

12 Ibidem, p. 158. 
En el desarrollo de objetos de aprendizaje es determinante tomar en consideración que la calidad académica que se pretenda lograr en los productos finales, su alcance y complejidad, inevitablemente estará influida por los recursos humanos y la disponibilidad financiera, puesto que el contar con especialistas de distintas disciplinas, garantizaría el logro de contenidos de calidad.

Por lo tanto, el desarrollo de competencias por parte del autor de objetos de aprendizaje implica tener en mente que el mayor valor de los mismos radica en que el contenido pueda ser reutilizado en entornos de red. Esta posibilidad les otorga a los objetos de aprendizaje un valor agregado inédito. No obstante, es deseable que el autor de contenido tenga conocimiento sobre los estándares educativos involucrados en el desarrollo y el uso de objetos de aprendizaje, así como la orientación del aprendizaje avanzado distribuido, con el propósito de comprobar si al utilizar elementos tecnológicos se logran armonizar las plataformas y los objetos de aprendizaje, se facilita el desarrollo de éstos, se mejora el intercambio de contenido educativo y se logra su reutilización a través de los entornos de redes.

\section{CONCLUSIONES}

La educación a distancia en bibliotecología en América Latina se incrementa en forma permanente; sin embargo, es indispensable investigar en forma permanente respecto a esta modalidad, con el propósito de asegurar el desarrollo de propuestas educativas y de contenidos didácticos que garanticen el logro de aprendizajes significativos en los estudiantes.

La globalización es un escenario complejo y multidimensional que afecta a las sociedades, y la sociedad de la información y la del conocimiento han producido cambios sustanciales dirigidos a la disciplina bibliotecológica y al ejercicio profesional; al mismo tiempo se han construido escenarios virtuales de comunicación que afectan a las sociedades. Se requiere entonces que los dise- 
ñadores de propuestas educativas a distancia, autores de contenido y tutores, cuestionen las posibilidades de las tecnologías que pretendan utilizar, los alcances de los modelos que se desarrollen, la conveniencia de los contenidos educativos y las prácticas pedagógicas que se utilizarán.

Por ello, una agenda de investigación facilita identificar fenómenos de estudio para la bibliotecología y, al mismo tiempo, señala una ruta de acción investigativa que orienta al determinar los requerimientos disciplinares y las exigencias sociales. Basta señalar que en la actualidad la sociedad manifiesta cambios en cuanto a las formas de trabajo, las maneras de interacción y la comunicación de los sectores sociales y las necesidades en cuanto al uso de información para su formación profesional.

En una agenda de investigación se debe considerar que, en el proceso de aprendizaje a distancia en bibliotecología, el docente es un facilitador en la asimilación de conocimiento, y elabora materiales didácticos que responden a las necesidades específicas de los alumnos, derivadas de sus condiciones laborales, sociales y culturales; por lo tanto, es necesario investigar en forma permanente respecto a la función y el uso actual de los sistemas bibliotecarios y de información en la educación a distancia.

Los modelos educativos a distancia en bibliotecología presuponen la creación de contextos colaborativos de aprendizaje basados en dinámicas de construcción grupal de saberes culturales. Sin embargo, es menester tener en mente que los escenarios y las comunidades donde se adopta el aprendizaje colaborativo no se generan en forma espontánea en el ciberespacio; más bien, se generan compromisos para los sujetos del acto educativo respecto a su participación activa y planificada atendiendo a un marco de intenciones de aprendizaje específicas y compromisos pedagógicos compartidos.

La educación a distancia en México ha acumulado experiencias de mucho valor; sin embargo, frente a los desafíos que se presentan en este inicio de siglo y considerando los escenarios de la educación a distancia que plantea la ANUIES, la UNESCO, la IFLA, y el propio Estado mexicano, es necesario que en una agen- 
da de investigación se consideren esos planteamientos para poder contar con elementos sustentados que sirvan para la toma de decisiones en el desarrollo de modelos educativos a distancia, la adecuada utilización de los recursos humanos, tecnológicos y financieros y el fortalecimiento de la cooperación entre las instituciones educativas mexicanas.

No obstante las diversas problemáticas y las tareas pendientes que tienen las organizaciones educativas de América Latina, en la actualidad se advierte que la modernización de la educación es uno de los proyectos relevantes de diversos organismos de Latinoamérica; se percibe que esto responde, entre otros aspectos, a programas globales en los que está presente la aplicación de políticas educativas y gubernamentales orientadas a efectuar cambios estructurales y constitucionales que respondan y le den coherencia a la participación educativa en un mundo global. Todo ello, sin duda, es de de mucha relevancia en una agenda de investigación relacionada con la educación a distancia en América Latina.

\section{REFERENCIAS BIBLIOGRÁFICAS}

Agenda de investigación educativa estatal, Dirección de Desarrollo Educativo. Departamento de Investigación, Chihuahua: Secretaría de Educación y Cultura, disponible en: http://portaladm.chihuahua.gob.mx/atach2/investigacioneducativa/uploads/ligas_fijas/AgenIEE.pdf (consulta: 15 de octubre de 2012).

Amador Bautista, Rocío, "Nuevos procesos educativos en el medio digital”, en El medio digital en el siglo XXI. Retos y perspectivas para los bibliotecólogos, investigadores, educadores y editores (editado en CD-ROM, 2001), Trabajo presentado en el XVIII Coloquio Internacional de Investigación Bibliotecológica. 
ANUIES, Plan maestro de educación superior abierta y a distancia. Lineas estratégicas para su desarrollo, disponible en: <http:// www.anuies.mx/pdf/Plan\%20Maestro1.pdf> (consulta: 2 de enero de 2012)

Bosco Hernández, Martha Diana, "Dos conceptos paradigmáticos en la formación docente, la Areté y la Bildung: Una propuesta de reflexión para la educación virtual", en Virtual Educa, 2005 (editado en CD-ROM) (consulta: 27 de junio de 2012).

Chacón Alvarado, Lucía, "Formación de profesionales en información: educación virtual en Centro América”, en Bibliotecas: boletín de la Escuela de Bibliotecología, Documentación e Información, 2000, Vol. 18, No. 1-2 (ene.-dic.), pp. 18-26.

Euroreferencial en información y documentación. V. 1 Competencias y aptitudes de los profesionales europeos de información y documentación, 2004, p.v.

Garduño Vera Roberto y Cabral Vargas, Brenda. "La investigación a distancia en bibliotecología en México y en América Latina", en Filiberto Felipe Martínez Arellano y Juan José Calva (comp.), Tópicos de investigación en bibliotecología y sobre la información, edición conmemorativa de los XXV años del Centro Universitario de Investigaciones Bibliotecológicas, México, UnAM: Centro Universitario de Investigaciones Bibliotecológicas, 2007, v2.

Guri-Rosenblit, Sarah. Distance and campus universities: tension and interactions. A comparative study of five countries, [s. 1.]: UNESCO, International Association of Universities and Elsevier Science Ltd., 1999, Traducción del capítulo final que comprende las páginas 240-242, por Tito Mejía Esparragoza. 
Lafuente López, Ramiro y Roberto Garduño Vera, "Enseñanza a Distancia de la Bibliotecología y Estudios de la Información", en Investigación Bibliotecológica: archivonomía, bibliotecología e información, jul./dic. 1999, Vol. 13, No. 27, p. 16.

Maura Sardó, Mariano A, "Conference on library education in Latin America", en Third World Libraries, 1993, Vol. 4, No. 1 (Fall), pp. 49-62.

Merlano Domínguez, Eulises, "Estado del arte sobre investigación en educación de niños menores de siete años en el Departamento de Magdalena", en Revista Electrónica EUREKA: Barranquilla, Colombia, vol1 (1999), disponible en: http://www.uninorte.edu.co/divisiones/humanidades/Eureka/Numero1/articulos5.htm （consulta: 11 de agosto de 2012).

Miller, Gary. E., "Research opportunities in distance education", en PAACE. Journal of Lifelong Learning, 1967, Vol. 6, pp. 1-7.

Munck, Gerardo L., "Agendas y estrategias de investigación en el estudio de la política latinoamericana", en Revista de Ciencia Política, 2007, Vol. 2, No. 1, pp. 3-21.

Muro Lozada, Xiomara y Sergio Serron, "La agenda de investigación en el proceso de transformación de las instituciones de educación superior (IES)", en Paradigma, 2007, Vol.28, Núm.1, pp. 07-38.

Notas para una agenda de investigación educativa regional, coordinado por Mario Rueda Beltrán, México: Consejo Mexicano de Investigación Educativa, 2006, 359 p.

Pérez, María Cristina, "Educación a distancia: una experiencia aplicada a la formación de recursos humanos para el sector información en el Uruguay", en Informatio, 1997, Vol., No. 2, pp. 27-35. 
Pedroza Flores, René, "Propuesta de un modelo curricular flexible para mejorar la calidad de la formación profesional", en DEP: Cuadernos para la Educación Pública, 2004, p. 159.

Perraton, Hilary, "Rethinking the research agenda", en International Review of Research in Open and Distance Learning, 2000, Vol. 1, No. 1, pp. 1-11.

UNAM, Coordinación de Universidad Abierta y Educación a Distancia (CUAED), Consejo Asesor, unAm, 2005 (documento de trabajo).

UNESCO, Rapport mondial sur la communication, citado por Rocío Amador Bautista, "Nuevos procesos educativos en el medio digital", en El medio digital en el siglo XXI: retos y perspectivas para los bibliotecólogos, investigadores, educadores y editores, México: unAM, CUIB [editado en CD-ROM], Trabajo presentado en el XVIII Coloquio Internacional de Investigación Bibliotecológica.

ZawackiI-Richter, Olaf, "Research areas in distance education: a Delphi study", en The International Review of Research in Open Distance Learning, June 2009, Vol. 10, No. 3, pp. 1-17. 


\title{
El Programa de Tutorías en la agenda de investigación institucional para la formación en ciencias de la información: experiencia de la Escuela de Ciencias de la Información de la Universidad Autónoma de San Luis Potosí
}

\author{
GuAdalupe Patricia RAMOS FANDiÑo \\ Y BEATRIZ RODRÍGUEZ SIERRA \\ Universidad Autónoma de San Luis Potosí, México
}

\begin{abstract}
T a Escuela de Ciencias de la Información (ECI) de la Universidad Autónoma de San Luis Potosí (UASLP) inició actividades en 1980, ofreciendo inicialmente la carrera de Licenciado en Biblioteconomía. Actualmente, ofrece la Licenciatura en Bibliotecología y la Licenciatura en Archivología, con una planta docente de 39 profesores y atiende a una población escolar de 440 alumnos. La Escuela tiene una trayectoria de 32 años y sus egresados ocupan plazas en todo el país y en unidades de información de todo tipo. La actualización y modificación de los planes de estudio de la entidad se lleva a cabo por medio de cuerpos colegiados, como la Comisión Curricular de la Escuela -conformada con Profesores de Tiempo Completo-, el Consejo Técnico Consultivo -el cual tiene que dar su aprobación para cualquier propuesta de modificación y actualización de los contenidos programáticosy las Academias -las cuales están integradas por Profesores de Tiempo Completo y Profesores Hora Clase, quienes trabajan permanentemente en la propuesta de actualización y modificación de contenidos programáticos de los dos programas de estudio.
\end{abstract}


En respuesta a las actuales tendencias de la educación superior y en apego a las políticas institucionales, la Escuela de Ciencias de la Información de la UASLP se ha preocupado desde hace seis años en ofrecer a sus estudiantes, como servicio educativo, el Programa de Tutorías, el cual consiste en asignar a cada estudiante un profesor-tutor que se encargue de darle "acompañamiento de tipo personal y académico a lo largo del proceso formativo para mejorar el rendimiento académico, ayudar a solucionar sus problemas escolares, y a desarrollar hábitos de estudio, trabajo, reflexión y convivencia social" (ANUIES, 2002).

El Programa Interno de Tutorías en la Escuela de Ciencias de la Información de la UASLP organiza cursos de tutorías para los profesores que imparten esta actividad, así como cursos para los alumnos, dirigidos a formar hábitos y estrategias de estudio, y a integrarse al ámbito universitario y aprender lo relacionado con la salud y la paternidad responsables, y canaliza a los alumnos hacia los diferentes programas de apoyo con los que cuenta la Universidad, como el deporte y cultura. En las siguientes líneas, procuraremos describir a grandes rasgos algunas de las actividades en las cuales interviene el Programa de Tutorías que se encuentra a cargo de la licenciada Ana Graciela Lechuga Páez.

La Escuela cuenta con un Programa de Tutorías que atiende al total de la población escolar, el cual fue elaborado en sesiones colegiadas considerando las mejores alternativas de seguimiento al desempeño escolar de los estudiantes. Un total de 15 Profesores de Tiempo Completo y 2 Profesores de 40 horas se encargan de atender la matrícula de la ECI para que, en promedio, cada uno de ellos atienda a 25 alumnos en tutoría. La actividad tutorial es coordinada por una responsable del programa, con formación en Psicología, que brinda el apoyo y la orientación necesarios para que cada profesor-tutor y cada alumno conozcan los alcances y objetivos del mencionado programa.

La actividad tutorial abarca diferentes aspectos de acuerdo con el grado de avance en la carrera del estudiante. Desde el primero hasta el tercer semestre, se considera la integración al medio universitario, y a la propia Escuela, al desarrollo de habilidades 
personales y a la orientación vocacional y profesional; desde el cuarto hasta el sexto semestre, la orientación atiende su integración a los servicios institucionales, como la movilidad estudiantil y los programas de verano de la ciencia, así como la semana nacional de ciencia y tecnología; en los últimos semestres de formación del estudiante, se refuerza su integración al campo laboral orientándolo hacia las diferentes opciones de servicio social y prácticas profesionales; se le brinda asesoría socio laboral y, en todos los casos, se le da seguimiento académico.

Con el fin de que los alumnos terminen sus estudios en los tiempos previstos, la ECI detecta, a través del seguimiento académico, casos de rezago y reprobación para dar asesoría personalizada a quien lo amerite. También se da seguimiento continuo al avance en los cursos de inglés para evitar rezagos importantes y se les proponen a los alumnos alternativas para regularizar su situación académica. Se cuenta con ocho modalidades de titulación para que, al momento de su egreso, el pasante elija la más conveniente de acuerdo con sus posibilidades. También se proporciona a los estudiantes un documento impreso en el que se les explican las modalidades, requisitos, procedimientos y protocolo de su examen profesional, lo cual ha simplificado y clarificado considerablemente los procedimientos y trámites necesarios para la titulación.

Los alumnos de las carreras de bibliotecología y archivología se han beneficiado con los programas estudiantiles institucionales, tales como el de la salud, que incluye servicios dentales, oftalmológicos y vacunas, prevención de adicciones y nutrición, entre otros. El programa de becas PRONABEs ha sido crucial para la continuidad de algunos alumnos con problemas económicos. Se organizan también actividades culturales, como el festejo del Día del Libro, el Día del Bibliotecario, el Día del Archivista, El Altar de Muertos, entre otros. Los estudiantes participan en actividades deportivas a través de los diferentes torneos en las diversas disciplinas. Para complementar la formación del alumnado, se organizan viajes de estudio tanto para visitar instituciones archivísticas y bibliotecarias, como para asistir a eventos bibliotecológicos y 
archivísticos que organizan diferentes instancias representativas de estos gremios.

Los alumnos de nuevo ingreso reciben en agosto de cada año un curso de inducción que tiene como finalidad guiarlos dentro de la normativa institucional interna, la difusión de los programas y servicios estudiantiles, y proporcionarles conocimientos y destrezas que favorezcan sus competencias universitarias. En este rubro, ha sido importante el apoyo del Programa Institucional de Orientación Educativa, que, a través de cursos, talleres y otras actividades con los estudiantes de primer ingreso, ha trabajado y colaborado para mejorar el índice de retención estudiantil. Los programas de la UASLP han guiado y ayudado a los estudiantes a tener una información oportuna en relación con control de adicciones, embarazos tempranos, higiene y el cuidado de la salud, conciencia ecológica y medioambiental, así como la prevención de accidentes y la seguridad personal.

En los últimos cuatro años se ha avanzado significativamente en la sistematización del programa interno de tutorías: el 100\% de los alumnos de las dos carreras cuenta con un tutor que apoya y da seguimiento a su desempeño individual. El tutor académico debe responsabilizarse de conocer la situación académica del estudiante y de proponerle actividades, proyectos o investigaciones que coadyuven a su formación integral.

En caso de presentarse problemas específicos que requieran atención especial de profesionales en las áreas psicológica, médica, psiquiátrica, etcétera, el tutor debe canalizarlos hacia alguna instancia adecuada en donde se analice a profundidad la problemática detectada.

Se da atención personalizada a los alumnos en relación con su situación académica, tanto en el Plan de Estudios como con los niveles de inglés que deben acreditar; los tutores de los alumnos procuran invitarlos a regularizar los niveles rezagados. Se apoyan las solicitudes de movilidad en el Verano de la Ciencia y las iniciativas de alumnos para asistir a eventos bibliotecológicos y archivísticos en otras entidades del país. Los alumnos cuentan con Consejería de Alumnos y Representantes ante el Consejo Técnico 
Consultivo, y a través de esas dos instancias proponen o solicitan apoyos.

La política de la ECI en relación con la formación integral del estudiante es la siguiente:

La ECI debe asegurar una atención integral a todos sus estudiantes para propiciar la formación de un profesional con un proyecto de vida sustentado en valores y articulados con proyectos sociales, que tengan su máxima expresión en la solidaridad, justicia social y mejoramiento humano.

Sus objetivos estratégicos en relación con la formación integral del estudiante se han planteado para buscar:

- Fortalecer el Programa de Tutoría.

- Promover el programa de movilidad estudiantil de la IES.

- Incrementar la eficiencia terminal de los PE de la DES.

- Promover la participación de los estudiantes de la ECI en los Programas Institucionales de Deportes, Cultura e Investigación.

- Promover el Programa Institucional de la Salud.

Las estrategias emprendidas para lo anterior se dirigen hacia:

- Continuar con las actividades de atención personalizada y grupal de los Estudiantes de la DES.

- Apoyar la tutoría con cursos de capacitación para los PTC (Profesores de Tiempo Completo) de la ECI.

- Evaluar semestralmente el Programa de Tutoría, con el fin de reducir los índices de deserción y rezago estudiantil.

- Apoyar a los estudiantes de alto rendimiento para su participación en el programa de movilidad estudiantil, así como su asistencia a eventos académicos de las ciencias de la información.

- Promover la participación de los estudiantes en proyectos de vinculación. 
- Promover las diferentes modalidades de titulación.

- Apoyar la participación de los estudiantes en los Programas Institucionales de Deportes, Cultura e Investigación.

- Difundir las actividades del Programa Institucional de la Salud.

Para lograr lo anterior, la ECI ha establecido el Departamento de Orientación y Tutorías, el cual fue creado para acompañar al alumno, beneficiarlo en su desarrollo académico, profesional y personal, a través de la TUTORíA, una serie de acciones a cargo de un TUTOR, que tiene como objetivo acompañar al alumno en su proceso de desarrollo, desde que ingresa a la Escuela de Ciencias de la Información, y así elevar el nivel educativo al máximo de sus potencialidades.

Beneficios:

- Facilita al estudiante su integración a la ECI, al Plan de Estudios y a la comunidad universitaria.

- Contribuye al desarrollo de competencias básicas y profesionales definidas en el perfil de egreso.

- El tutor acompaña al alumno en la toma de decisiones académico-profesionales y lo orienta en la etapa de transición al mundo socio laboral.

Este Departamento da a conocer su plan de acción, programa, grupos y tutores, documentos, avisos de actividades y buzón en un subsitio de la página de la Escuela en la siguiente dirección electrónica: http://www.eci.uaslp.mx/Tutorias/index.html.

Considerando la experiencia en este ámbito de la Escuela de Ciencias de la Información de la UASLP se ha considerado la posibilidad de establecer un trabajo en red entre las diferentes instituciones del país que imparten las carreras de bibliotecología y archivología, para intercambiar experiencias y dar a conocer buenas prácticas, partiendo de un análisis de los sistemas que pueden influir en el funcionamiento de la tutoría, como pueden ser: 
- La organización académica propia de las instituciones.

- La estructura y políticas de los departamentos, facultades y universidades.

- El entorno social y productivo.

- Los retos del campo profesional o disciplinario.

Todo esto, con el fin de implementar procesos eficientes en cada institución y tomar ventajas de las experiencias en el campo de la formación en las ciencias de la información en México, buscando que una tutoría bien encaminada y dirigida permita:

- Orientar, dirigir, impulsar y facilitar el desarrollo integral de los estudiantes.

- Personalizar la transmisión de conocimientos en casos concretos y especiales.

- Hacer que la tutoría se constituya en un elemento clave de calidad.

- Canalizar y dinamizar las relaciones del alumnado con los diferentes segmentos de atención.

- Compartir experiencias en foros, seminarios y/o talleres sobre tutorías y, a partir de ellos, presentar trabajos de investigación a manera de compilación temática.

- Fortalecer en las instituciones formadoras, los programas de movilidad estudiantil y la asistencia a eventos bibliotecológicos interinstitucionales en donde los alumnos compartan experiencias e iniciativas identificadas a través de la actividad tutorial.

- Desarrollar propuestas para la capacitación adecuada de la planta docente en la teoría emergente de Tutorías en la Educación Superior.

A partir de las reuniones de directores de las instituciones formadoras de recursos humanos en el campo de las ciencias de la información, consideramos que en el mediano plazo se puede establecer formalmente una agenda de investigación en tutorías 
que resulte de interés y beneficio para todos. El esquema inicial puede ser como se muestra en la Figura 1:

Figura 1.

Propuesta de agendas de investigación en tutorías en las instituciones formadoras en ciencias de la información en México.

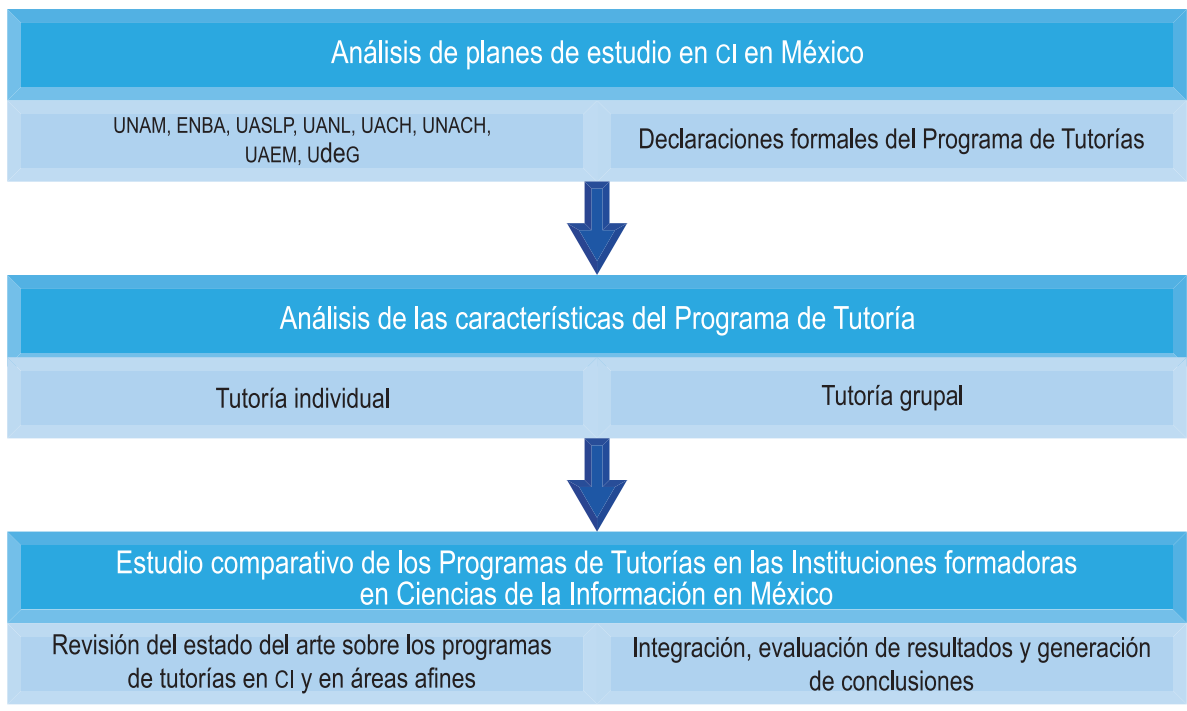

I Coloquio de Investigación Bibliotecológica y de la Información

\section{CONSIDERACIONES FINALES}

1. La posibilidad de realizar trabajo colaborativo en el ámbito de tutorías entre las instituciones formadoras en ciencias de la información en el país es plausible.

2. Un trabajo como el aquí propuesto podrá servir para proponer el perfil ideal del profesor-tutor en ciencias de la información.

3. El desarrollo de investigaciones sobre modelos educativos centrados en el alumno que incluyan las tutorías podrá mejorar la eficiencia terminal en las instituciones formadoras en ciencias de la información. 
4. La tutoría adecuadamente llevada en las instituciones formadoras en ciencias de la información contribuirá a dar soluciones prácticas que se presentan en el servicio social y las prácticas profesionales del alumno.

5. Resulta conveniente realizar estudios de impacto de la actividad tutorial entre generaciones de egresados que la han contemplado en su plan de estudio y aquellas que no (para justificar la inversión de tiempo, recursos humanos y recursos financieros).

\section{REFERENCIAS BIBLIOGRÁFICAS}

ANUIES (2002), Programas institucionales de tutoría: una propuesta de la ANUIES para su organización y funcionamiento en las instituciones de educación superior, México: Asociación Nacional de Universidades e Instituciones de Educación Superior.

Fresán Orozco, Magdalena y Alejandra Romo López (coord.) (2011), Programas Institucionales de Tutoría, una propuesta de la ANUIES, México: Asociación Nacional de Universidades e Instituciones de Educación Superior.

Pastor, E. y J. Román (1980), La tutoría: pautas de acción e instrumentos útiles al profesor tutor, Madrid: CEAC.

Universidad Autónoma de San Luis Potosí. Escuela de Ciencias de la Información (2011), Departamento de orientación y tutorías, disponible en: http://www.eci.uaslp.mx/Tutorias/

Universidad Autónoma de San Luis Potosí. Escuela de Ciencias de la Información (2012), Programa de fortalecimiento 2012-2013 de la Escuela de Ciencias de la Información, coord. por Guadalupe Patricia Ramos Fandiño y otros, disponible en: http://www.uaslp. $\mathrm{mx} / \mathrm{spanish} /$ administracion/academica/dpea/planesyprogramas/ Paginas/default.aspx 


\title{
La desigualdad en el uso de la información en las comunidades indígenas: una línea de investigación pertinente
}

\author{
César Augusto Ramírez VelázQuez \\ Universidad Nacional Autónoma de México
}

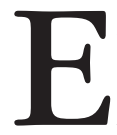
1 empleo de las tecnologías ha incrementado el acceso a la información a través de diversas fuentes, que se han transferido del soporte en papel y electrónico al soporte digital. Estos cambios han repercutido en la sociedad mexicana en su forma de buscar, encontrar y acceder a la información que requiere.

En el caso de las comunidades indígenas del país, el uso de las tecnologías de información y comunicación (TIC) ha sido heterogéneo ya que, por un lado, existe un grupo que las ha incorporado a sus actividades cotidianas, sobre todo laborales, para indagar sobre diversos aspectos fuera de su comunidad, por ejemplo: ¿cómo viven las personas en las ciudades?, ¿qué tipo de alimentos consumen?, ¿qué clase de actividades realizan?, ¿cuáles son los costos de producción de ciertos cultivos?, ¿dónde se pueden conocer los precios actuales de diversos productos?, ¿cuáles son las ofertas educativas del Estado en el nivel superior?, ¿cómo puedo establecer contacto con miembros de la comunidad que han emigrado?, entre otros.

A estas comunidades se les puede denominar usuarias 2.0 tanto por los recursos económicos y la infraestructura con que cuentan como por los servicios de Internet que usan, entre los cuales podemos 
mencionar Internet inalámbrico, la Web 2.0, las redes sociales, diversas aplicaciones, recursos tecnológicos, medios de comunicación (radio, televisión telefonía) y unidades de información. En México figuran en este aspecto las comunidades indígenas de Zacatecas, Michoacán y Oaxaca.

¿Qué factor ha influido primordialmente para que hayan desarrollado el uso de tecnologías de la información y medios de comunicación? La respuesta parece ser muy simple, sin embargo, lleva una connotación muy profunda y es el hecho principal de retirarse de sus lugares de origen. Las personas emigran a otros lugares no sólo a nivel nacional, y al momento de instalarse buscan la manera de restablecer comunicación con los individuos que se quedaron en sus comunidades, llevando recursos tecnológicos o enviando recursos económicos para la adquisición de medios de información y comunicación que aprendieron a utilizar en las localidades donde se encuentran asentados.

Otro grupo que se ha podido detectar es aquel que, teniendo las tecnologías y los medios a la mano, sólo los utilizan para realizar actividades relacionadas con la escuela (en el caso de los niños y jóvenes), para comunicarse por medio de mensajes, chat o correo electrónico con individuos de la misma o de otras localidades y para organizar pequeños negocios familiares mediante paquetería básica con procesadores de texto, paquetes estadísticos y de presentaciones; así como algunos programas y aplicaciones de entretenimiento. Cabe mencionar que si bien este grupo tiene recursos económicos y cuenta con las tecnologías pertinentes para hacer un uso más intenso de programas, aplicaciones y servicios, no los explota adecuadamente.

El último grupo lo forman aquellas comunidades cuya situación económica, geográfica y de infraestructura no les permite tener acceso a las tecnologías, es decir, se encuentran en una situación precaria en la que carecen de servicios eléctricos y por ende electrónicos que impiden la integración de las TIC en la localidad. Así, la comunicación y la información que normalmente utilizan sigue siendo tradicional, transmitida de forma oral y en estrecha relación con los miembros de su comunidad: familiares, amigos y en 
su caso el Consejo de Ancianos, lo que implica un acercamiento esporádico a otros grupos sociales.

El panorama antes descrito muestra una gran desigualdad entre la información que utilizan unos grupos y otros. Las comunidades indígenas usuarias utilizan tanto la radio como la televisión y la telefonía de forma constante, tienen establecidas unidades de información virtuales y digitales a través de Internet y otros medios electrónicos, cuentan con infraestructura que les permite acceder a todo tipo de información y poseen suficientes recursos económicos. En contraste, las comunidades no usuarias tienen un acercamiento esporádico a otros grupos sociales, por lo tanto su acceso a otro tipo de información es limitado, el conocimiento del mundo no se amplía, carecen de infraestructura y no poseen capacidad económica.

Ahora bien, ¿con qué fin se debe hacer investigación al respecto? Por un lado se considera que, para mejorar y homologar las condiciones de apropiación, uso y democratización de las tecnologías informativas y de comunicación entre las comunidades, es pertinente:

- Abatir la brecha digital entre comunidades. Debido a la gran desigualdad en el acceso y uso de estas tecnologías entre las comunidades, es menester considerar prioritaria esta área de oportunidad para hacer estudios e investigaciones que conlleven a detectar y especificar el tamaño de la brecha, los factores que han incidido en su surgimiento y proyectar el abatimiento de la misma.

- Homologar la distribución de recursos tecnológicos para la recuperación y acceso a la información. Es un hecho que en México se ha pensado que es muy costoso implementar una red de datos que logre conectar a todas las comunidades, aun aquellas que se encuentran en los confines del territorio nacional. No obstante, se está considerando la posibilidad de utilizar la red eléctrica que actualmente existe a nivel nacional para la recepción y el envío de datos, lo que abatiría los costos de diseño e implementación de una nueva red, 
amén de que se podrían utilizar los recursos económicos ahorrados para la adquisición y entrega de recursos tecnológicos a las comunidades que lo requieran.

- Ampliar la utilización de medios de comunicación. Algunas comunidades utilizan todo los medios de la Web 2.0 con los cuales se pueden comunicar gratuitamente; otras únicamente utilizan la radio para comunicarse y brindar información interna (aunque existen algunas que no cuentan con este medio), el flujo de esta información es endogámico pues la información sólo se transmite entre las familias o entre parientes y amigos de la misma localidad. Cuando logren usar la tecnología de información y los medios de comunicación de manera más expedita y con mejores recursos, obtendrán información nueva, abundante e interesante; asimismo, ampliarán su universo y se comunicarán con sus congéneres y otros individuos ubicados fuera de la comunidad.

- Eliminar las diferencias de infraestructura bibliotecaria $y$ de información entre comunidades. Al integrar instituciones bibliotecarias en cada una de las poblaciones indígenas, con medios de comunicación que garanticen un servicio y un flujo de intercomunicación constante, ya sea verbal, visual o escrita, se empezará a construir un sistema de información que apoyará a las comunidades a descubrir otras formas de organización, métodos de trabajo, condiciones para la incorporación a otros niveles de vida, establecer conductas que les permitan adecuar su interacción con las sociedades que los rodean, entre otros aspectos importantes para su desarrollo.

- Políticas públicas. En este rubro es necesario generar una serie de estudios que conlleven a la formación de propuestas específicas y viables para que el Estado las incorpore en su Plan Nacional de Desarrollo, con el fin de que la desigualdad existente entre las comunidades indígenas no siga persistiendo. Esta es otra área de oportunidad importante e interesante que se puede abordar de manera interdisciplinaria. 
- Uniformar servicios de información para el conjunto de comunidades. Como ya se comentó en párrafos anteriores, en Zacatecas, Oaxaca, Michoacán y en algunos otros lugares como Nayarit y Colima utilizan una serie de servicios de información por medio de redes e Internet que no solamente van dirigidos a jóvenes y niños, sino también a los adultos y a la gente de todas las edades que tiene la necesidad de emigrar. Algunas de sus necesidades de información son las siguientes: ¿qué solicita el consulado para apoyar la tramitación de trabajos temporales en otro país?, ¿qué se requiere, dónde y cómo se tramita un pasaporte?, ¿cómo se pueden enviar recursos económicos sin riesgo a los familiares? Como se puede observar, la información que requieren los emigrantes es muy extensa por lo que se deben considerar servicios muy precisos. Asimismo, a la gente adulta de esas comunidades se les podrían ofrecer servicios electrónicos para pagar los impuestos, el predial, la tenencia de automóviles, el agua, y la electricidad.

- Establecer planes de capacitación y de formación en el área para individuos nativos. La incorporación de miembros de la propia comunidad en el trabajo y las actividades que comprenden los servicios con tecnologías de la información y la comunicación es un punto crucial en la atención de las poblaciones indígenas, por ello es de suma importancia generar un programa de capacitación y formación de técnicos y profesionales dirigido a los individuos de las propias comunidades, quienes colaborarían en ellas trabajando en unidades de información que operen con recursos impresos, electrónicos y digitales.

- Constituir estudios de necesidades de información de las comunidades indígenas. La mayoría de las veces, la conformación de unidades de información ha surgido sin tener conocimiento de los individuos a los que se les proporcionarán los servicios, es decir, no se sabe a ciencia cierta para quién se están construyendo edificios, planeando servicios, adquiriendo y organizando documentos, incorporando tecnologías 
de información y comunicación. En este sentido, es de vital importancia que se elaboren estudios de necesidades de información de las comunidades indígenas antes de planear, construir e implementar un recinto bibliotecológico y de información, con el fin de que a partir de sus resultados se conozcan sus requerimientos informativos y se visualice una entidad bibliotecológica e informativa que verdaderamente los apoye con servicios y productos de calidad en la búsqueda de respuestas veraces y oportunas.

- Impulsar la creación de sistemas de información adecuados a las necesidades informativas de las comunidades indígenas. Después de conocer qué es lo que requieren en cuanto a información, se podrán establecer una serie de iniciativas y proyectos que faciliten la construcción o adecuación de edificios bibliotecarios y de información con una infraestructura tecnológica y digital que contemple una serie de servicios de calidad, necesarios para apoyar su desarrollo social, económico y cultural.

A partir de las consideraciones anteriores, se presentan a continuación algunas propuestas con las que se puede constituir una agenda de investigación que permita generar proyectos que acerquen los servicios de información necesarios a las comunidades indígenas:

- Promover el uso de sistemas de información. La elaboración de proyectos de investigación encaminados a la planeación, organización y distribución de medios computacionales, electrónicos y digitales que permitan el acceso y uso de sistemas de información a través de discos compactos o de redes como Internet, para que estos recursos se conviertan a su vez en medios de información comunes para la población indígena.

- Realizar proyectos de investigación encaminados a la edición de material literario. La producción de documentos académicos y científicos en lenguas indígenas sobre diversas 
disciplinas es un área de oportunidad en diversos temas, entre ellos la cosmogonía de los pueblos originarios, la medicina tradicional y los conocimientos de herbolaria y botánica. Es importante mencionar la trascendencia y riqueza de resultados que tendrían estos proyectos si se llevaran a cabo con los propios dueños del conocimiento, es decir, los chamanes, curanderos rituales, curanderos yerberos, chamanes sabios, entre otros, cuyo vasto conocimiento aportaría información importante recolectada por generaciones de individuos y comunicada por tradición oral.

- Un área más de oportunidad para desarrollar trabajos de investigación es la relativa al impulso al hábito de la lectura en lenguas nativas y en español. Estos proyectos se pueden integrar a través de las bibliotecas públicas con los proyectos mencionados en el párrafo anterior y con los proyectos de alfabetización de organismos gubernamentales y no gubernamentales, con el fin de elevar las estadísticas de alfabetización y de lectura a nivel nacional.

El factor humano siempre es imprescindible en el establecimiento de proyectos de largo alcance, sobre todo cuando se integran diversas disciplinas y profesiones. La realidad actual demanda que se trabaje interdisciplinariamente con mayor frecuencia, por lo cual la colaboración de bibliotecólogos, sociólogos, etnólogos, arqueólogos, comunicólogos, historiadores, geógrafos, ingenieros, médicos, gastrónomos, veterinarios, químicos, físicos, economistas, biólogos, botánicos y pedagogos permitirá que cada uno aporte, con su experiencia, el conocimiento necesario para lograr los objetivos planteados.

Por último, vale la pena preguntar ¿cuáles son los retos para confrontar la desigualdad en el uso de la información y concretar proyectos de investigación pertinentes para las comunidades indígenas? A manera de respuesta se puede mencionar la conformación de grupos multi, inter y transdiciplinarios, que junto a organismos gubernamentales y no gubernamentales involucrados con las comunidades indígenas se comprometan a consolidar redes 
académicas nacionales e internacionales y para apoyar con recursos de todo tipo la puesta en marcha de las propuestas resultantes de los proyectos.

\section{Bibliografía}

Doueihi, M. (c2010), La gran conversión digital, Buenos Aires, México: Fondo de Cultura Económica, 229 pp.

Flores Simental, R. (2008), ¿Qué es la brecha digital?: una introducción al nuevo rostro de la desigualdad, Ciudad Juárez: Universidad Autónoma de Ciudad Juárez, 129 pp.

"La brecha digital, un concepto social con cuatro dimensiones" (2003), en Boletín de Política Informática, núm. 6, disponible en http://www.inegi.org.mx/inegi/ contenidos/espanol/prensa/contenidos/articulos/tecno logia/brecha.pdf (consultado el 30 de septiembre de 2012)

Pobreza digital: las perspectivas de América Latina y el Caribe (2009), México: Centro de Investigación y Docencia Económicas, 213 pp.

Rodríguez Gallardo, A. (2006), La brecha digital y sus determinantes, México: UNAM/Centro Universitario de Investigaciones Bibliotecológicas.

Serrano Santoyo, A. y Evelio Martínez Martínez (2003), La brecha digital: mitos y realidades, México: UABC, 175 pp. 
Agendas de investigación en bibliotecología e información: tendencias nacionales e internacionales. Coordinación editorial, Carlos Ceballos Sosa; revisión especializada, formación editorial y revisión de pruebas, Desarrollo Integral para Empresas DIPE. Formación de preliminares y último capítulo, Mario Ocampo Chávez. Instituto de Investigaciones Bibliotecológicas y de la Información/UNAM. México, D.F. Se terminó de producir en el mes de septiembre de 2013 . 